\title{
EFECTO DE LA INCLUSIÓN DE FUENTES PROTEICAS Y LIPÍDICAS EN LA ALIMENTACIÓN DEL SARGO PICUDO “Diplodus puntazzo”
}

Silvia Nogales Mérida

Valencia, Noviembre 2011

Tutoras:

Dra. Ana Tomás Vidal

Profesora Títular de Universidad

Dra. Silvia Martínez Llorens

Contratado Doctor 

ANA TOMÁS VIDAL PROFESORA TITULAR DE LA UNIVERSIDAD

POLÍTECNICA DE VALENCIA

SILVIA MARTINEZ LLORENS PROFESOR CONTRATADO DOCTOR DE LA UNIVERSIDAD POLÍTECNICA DE VALENCIA

Informan:

Que la Tesis Doctoral titulada: EFECTO DE LA INCLUSIÓN DE FUENTES PROTEICAS Y LIPÍDICAS EN LA ALIMENTACIÓN DEL SARGO PICUDO “Diplodus puntazzo" ha sido realizadas por la Licenciada en Biología Dña. Silvia Nogales Mérida en el Departamento de Ciencia Animal bajo su dirección y que, una vez revisado y comprobado el trabajo, consideran que reúne los requisitos necesarios para la obtención del grado de Doctor, por lo que autoriza su presentación.

Y para que así conste firman el presente informe en Valencia a de de dos mil once.

Fdo.: Dra. Ana Tomás Vidal

Fdo. Dra. Silvia Martínez Llorens 

A mis tutoras, Dra. Ana Tomás y Dra. Silvia Martínez por su continua ayuda y apoyo en la redacción de los artículos y la presente tesis doctoral.

Al Dr. Miguel Jover por sus conocimientos e inestimable experiencia.

Al Dr. Javier Moya por su paciencia, su enseñanza y todos los dolores de cabeza que le he dado al realizar los análisis de aminoácidos y ácidos grasos.

A todos mis compañeros del departamento de Ciencia Animal con quienes he compartido todo este tiempo, especialmente al grupo de Acuicultura (Rosa, Pablo, Victor, Mamen, David, Fernando, Nacho) y al "grupo latino" (Nury, Jorge y Rafael) por su compañerismo y amistad.

$\mathrm{Al}$ resto de profesores y todo el personal que trabajan en este departamento.

A Antonio por sus ánimos y consejos en la maquetación de la presente tesis. 

INDICE

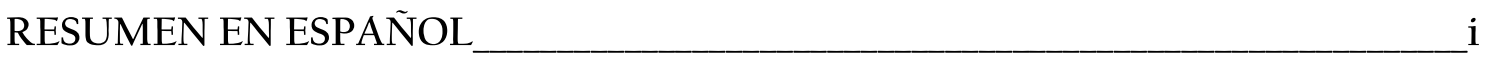

RESUMEN EN VALENCIANO____ iii

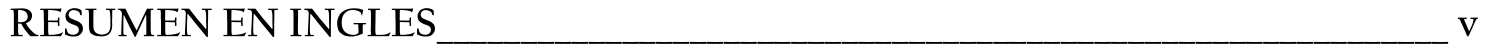

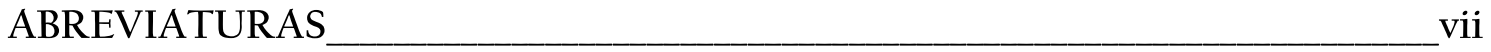

CAPITULO 1. INTRODUCCIÓN GENERAL ___ 3

1.1. UNA ESPECIE ALTERNATIVA PARA LA ACUICULTURA DEL

MEDITERRANEO _ 3

1.2. LAS HARINAS Y ACEITES DE PESCADO

1.2.1. SUSTITUCIÓN DE LA HARINA DE PESCADO ___ 5

1.3. NECESIDADES LIPÍDICA Y DE ÁCIDOS GRASOS EN LOS PECES

MARINOS $\mathbf{1 0}$

1.3.1. SUSTITUCIÓN DEL ACEITE DE PESCADO____

1.4. ALTERACIONES DEL HÍGADO E INTESTINO DE LOS PECES

PRODUCIDOS POR LA ALIMENTACIÓN. 15

1.5. CALIDAD NUTRICIONAL DE LA CARNE__ 17

1.6. BIBLIOGRAFÍA _ 19

CAPÍTULO 2. JUSTIFICACIÓN Y OBJETIVOS ___ 37

CAPÍTULO 3. PLAN EXPERIMENTAL___ 41

CAPITULO 4.

Sunflower meal as a partial substitute in juvenile sharpsnout sea bream

(Diplodus puntazzo) diets: Aminoacids retention, gut and liver histology __ 45

CAPÍTULO 5

Sharpsnout sea bream (Diplodus puntazzo) growth and health status alterated by Pea Protein Concentrate__ 55

CAPÍTULO $6 \ldots 75$

A study of parcial replacement of fish meal with sunflower meal on growth, aminoacid retention, and body composition of sharpsnout seabream,

Diplodus puntazzo (Actinopterygii): Perciformes: Sparidae)___ 75

CAPÍTULO $7 \_89$

Gradual fish oil substitution by soybean oil and Diplodus puntazzo juveniles' performance. Fatty acid profile and liver histology.___ 89 CAPÍTULO 8 105

Growth performance, histological alterations and fatty acid profile in muscle and liver of sharp snout sea bream (Diplodus puntazzo) with partial replacement of fish oil by pork lard 105 CAPITULO 9

Effect of partial inclusion of alternative lipid sources in sharpsnout sea bream. _121 
CAPÍTULO 10 137

DISCUSIÓN GENERAL 137

CAPITULO 10. DISCUSION GENERAL 139

10.1. FUENTES PROTEICAS ALTERNATIVAS. 141 AMINO ÁCIDOS Y RETENCIONES AMINOACÍDICAS 143

10.2. SUSTITUCIÓN DEL ACEITE DE PESCADO 147

10.3. CALIDAD NUTRICIONAL DEL FILETE DEL SARGO 154

10.4. ALTERACIONES HISTOLÓGICAS DEBIDAS A LA UTILIZACION DE FUENTES PROTEICAS Y LIPIDICAS ALTERNATIVAS EN EL SARGO PICUDO 157

10.5. BIBLIOGRAFÍA 160

CAPITULO 11. CONCLUSIONES 169 


\section{RESUMEN EN ESPAÑOL}

El sargo picudo es una especie promisoria para la producción acuícola española, aunque ésta ya se encuentra en mercados como Italia, Grecia y Chipre entre otros. Una de las ventajas que tiene sobre las especies que actualmente copan el mercado español, es su hábito alimenticio, su fácil reproducción y el hecho de que se puede emplear la misma infraestructura para su producción, además de ser una especie que goza actualmente de un precio competitivo en el mercado.

Todas las ventajas anteriormente citadas hacen de esta especie una de las especies potenciales para su producción a nivel comercial. No obstante, para la producción de la misma no se cuenta con piensos específicos, sino que se emplean piensos de dorada para su alimentación. Por ello, el objetivo de la presente tesis ha sido el incluir parcialmente el turtó de girasol (TG) y concentrado proteico de guisante (CPG) en dietas para el sargo picudo. De igual forma sustituir parcialmente el aceite de pescado (AP) por aceite de soja (AS) y manteca de cerdo (MC).

En los experimentos de inclusión de TG no se encontraron diferencias en el crecimiento de los peces alimentados con las dietas con 0, 12, 24 y 35\% tanto en la fase de pre-engorde como de engorde. De igual forma, no se alteraron ni el perfil ni la eficiencia de la retención aminoacídica con la inclusión de esta fuente vegetal. Al observar la histología del intestino e hígado, no se observó ninguna modificación significativa, por lo que se podría indicar que la inclusión de hasta un 35\% TG en la dieta para sargos picudos no afectaría ni la calidad del animal ni su salud en periodos inferiores a 160 días de alimentación. No obstante, al final de la fase de engorde, el crecimiento se ralentizó debido posiblemente al descenso gradual de la temperatura, y a que tal vez, los peces entraron en fase reproductiva, ya que similar resultado se observó en los sargos de engorde alimentado con fuentes lipídicas alternativas en la misma época del año.

La inclusión del CPG influyó en el crecimiento de los sargos picudos al final de la fase de pre-engorde, inclusive con la mínima inclusión que fue del 16\%. Esta reducción del crecimiento no afectó ni a al perfil aminoacídico de los peces ni a la eficiencia de la retención. El crecimiento se vio comprometido posiblemente por la presencia de compuestos anti nutricionales termo resistentes y la deficiente suplementación de metionina en las dietas, las cuales a su vez, causaron algunas 
alteraciones en las vellosidades intestinales, como la elongación de las mismas y el aumento de células caliciformes, como una respuesta para mejorar la absorción de nutrientes por parte del animal.

Se sustituyó el AP hasta un 75\% por AS y MC en la fase de pre-engorde, incluyendo un $24 \%$ de TG, según los resultados obtenidos en los experimentos anteriores. Las diferentes dietas ensayadas no produjeron ninguna diferencia significativa, ni en el crecimiento, ni en la eficiencia nutritiva. No obstante, se observó que el perfil de ácidos grasos en el músculo de los peces se alteró hasta con la mínima sustitución (25\%), tanto en los alimentados con AS como con MC, aunque esta alteración no fue tan marcada cuando se incluyó MC. Por otra parte, no se observó ninguna anomalía a nivel histológico tanto en los peces alimentados con AS como aquellos que consumieron MC.

Una vez concluida la fase pre-engorde, se realizó una fase de engorde, para la que se empleó un 50\% AS y MC como único nivel de sustitución, previendo efectos negativos en las sustituciones máximas empleadas en los experimentos anteriores tanto a nivel histológico como sensorial. Al final del experimento, no se obtuvieron diferencias significativas en el crecimiento. Sin embargo, la sustitución de AP por MC empeoró el ICA. La sustitución del AS y MC influyó en el perfil de ácidos grasos (AG), pero nuevamente se constató que el sargo muestra una menor alteración del perfil de AG muscular, cuando se alimentó con dietas en las que la sustitución de AP fue por MC. A través de la histología se observó que los sargos alimentados con AP y MC presentaron esteatosis. A pesar de que el perfil de AG estuviera en concordancia con las fuentes lipídicas suministradas en las dietas, se vio a través de las catas y los índices de aterogenicidad y trombogenidad, que los filetes del sargo no sólo no presentaron diferencias significativas a nivel organolépticos, sino que serían saludables para el consumo humano. 


\section{RESUM EN VALENCIÀ}

El sarg punxegut és una espècie promissòria per a la producción aqüícola española, encara que esta ja es trova en mercats com Itàlia, Grècia i Xipre entre altres. Un dels avantatges que te sobre les espècies que actualmente copen el mercat espanyol, és el seu hábit alimentari, la seua fàcil reproducció i el fet de que es pot emprar la mateixa estructura per a la seua producción, a més de ser una espècie que gaudix actualmente d'un preu competitiu en el mercat.

Totes les avantatges anteriorment citades fan d'esta espècie una de les espècies potencials per a la seua producció a nivel comercial. No obstant això, per a la producció de la mateixa no es compta amb pinsos específics, sino que es fan servir pinsos de daurada per a la seua alimentació. Per aixó, lobjectiu de la present tesi ha sigut l'incloure parcialment el turtó de gira-sol (TG) i concentrat protèic de pésol (CPG) en dietes per al sarg punxegut. De la mateixa manera substituir parcialment l'oli de peix (AP) per oli de soja (AS) i sagí de porc.

En els experiments d'inclusió de TG no es van trobar diferències en el creixement dels peixos alimentats amb les dietes amb 0, 12, 24 i 35\% tant en la fase de preengreixament com en la d'engreixament. De la mateixa manera, no es van alterar ni el perfil ni l'eficiència de la retenció d'aminoàcids amb la inclusió d'aquesta font vegetal. A l'bservar la histología de el intestí i el fetge, no es va observar cap modificació significativa, per la qual cosa es podría indicar que la inclusió fins a un 35\% TG en la dieta per a sarg punxegut no afectaría ni a la qualitat del animal ni a la seua salut en períodes inferiors a 160 dies d'alimentació. No obstant això, al final de la fase d'engreixament, el creixement es va ralentitzàr degut possiblement al descens gradual de la temperatura, i a que tal volta, els peixos entraren en fase reproductiva, ja que semblant resultat es va observaren els sargs d'engreixament alimentats amb fonts lipídiques alternatives en la mateixa època de l'any.

La inclusió del CPG va influir en el creixement de els sargs punxeguts al final de la fase de preengreixament, fins i tot amb la mínima inclusió que va ser del 16\%. Esta reducció del creixement no va afectar ni al perfil d'aminoàcids dels peixos ni a l'eficiència de retenció. El creixement es va veure compromés 
possiblement per la presència de compostos anti nutricionals termo resistents i la deficient suplementació de metionina en les dietes, les quals als seu torn, van causar algunes alteracions en les vellositats intestinals, com l'elongació de les maiteixes i l'augment de cèl.lules caliciformes, com una resposta per a la millor absortció de nutrients per part de l'animal.

Es va substituir el AP fins a un $75 \%$ per AS i MC en la fase de preengreixament, incloent un $24 \%$ de TG, segons els resultats obtinguts en els experiments anteriors. Les diferents dietes assajades no van produir cap diferència significativa, ni en el creixement, ni en l'eficiència nutritiva. No obstant això, es va observar que el perfil d'acids grassos en el múscul dels peixos es va alterara fins i tot en la mínima substitució (25\%), tant en els alimentats amb AS com amb MC, però esta alteració no va ser tan marcada quan es va incloure MC. D’altra banda, no es va observar cap anomalía a nivel histològic tant en els peixos alimentats amb AS com en aquells que van consumir MC.

Una vegada conclosa la fase preengreixament, es va realitzar una fase d'engreixament, per a la que es va emprar un 50\% AS i MC com únic nivel de substitució, preveient efectes negatius en les substitucions màximes empleades en els experiments anteriors tant a nivel histològic com sensorial. Al final de l'experiment, no es van obtindre diferències significatives en el creixement. No obstant aixó, la substitució de AP per MC va empijorar el ICA. La substitució del AS i MC va influir en el perfil d’àcids grassos (AG), però novament es va constatar que el sarg mostra una menor alteració del perfil de AG muscular, quan es va alimentar amb dietes en què la substitució de AP va ser per MC. A través la histología es va observar que els sargs alimentats amb AP i MC presentaven esteatosi. A pesar de que el perfil de AG estiguera en concordança amb les fonts lipidiques subministrades en les dietes, es va veure a través dels tastos i els índexs d'aterogenicitat i trombogenitat, que els filets de sarg no sols no presentaven diferències significatives amb el nivel organolèptic, sinó que serien saludables per al consum humà. 


\section{ENGLISH SUMMARY}

Sharpsnout sea bream is a promising specie to Spanish aquaculture, although, this fish is already in Italy, Greek and Cyprus markets among others. It has many advantages: It is omnivorous specie; it is easy to reproduce. Aquacultures' farmers can use the same infrastructure used to produce other sparids. Nowadays, it has a competitive market price.

For all the reason mention above, this fish is potential specie for aquaculture production, although, there is not a specific meal for raising them. Right now, most of the aquaculturists use gilthead sea bream meal to feed them. So the main objective of this Doctoral thesis is replace fish meal (FM) by sunflower meal (SFM) and pea protein concentrate (PPC) to raise sharpsnout sea bream fingerlings and juveniles. Other main objective is to partially substitute fish oil (FO) by soybean oil (SO) and pork fat (PF) to raise sharpsnout sea bream fingerlings and juveniles.

Sharpsnout sea bream were fed with 0, 12, 24 and 35\% of SFM. There was neither significant difference in fingerlings final fish growth nor in juveniles at the end of the experiments. At the same time, the amino acids profile and the efficiency of amino acids retention were not altered by SFM inclusion. It could consider until 35\% SFM inclusion, sharpsnout sea bream could not affect either flesh quality or animal health for not longer than 160 days. At the end of fattening period, fish growth became slow, perhaps due to decreasing temperature or reproduction period. Similar behavior was observed in D. puntazzo fattening period but with lipid sources, at the same time of the year.

Pea protein meal inclusion affected sharpsnout sea bream final weight at the end of the pre - growth period, even with the minimum inclusion $(16 \%)$. This growth reduction did not affect either amino acids profile or amino acid retention. Final growth was altered because of the presence of some anti-nutritional compounds that were thermo resistant. Another cause could be the deficient methionine supplementation in the experimental diets. Both alterations could cause some gut modification, like villous length elongation and goblet cells augmentation, to compensate nutrient miss absorption. 
After these experiments, FO was partially replaced by SO and PL, 75\% as a maximum substitution. In these diets $24 \%$ of SFM were included, according with the results obtained in previous experiments. There were no statistical differences in final fish growth at the end of the pre - growth experiment or "fingerling period". Although, fatty acids profile of fish fillet was altered by alternative lipid sources, even with the minimum substitution in SO and PL. Nevertheless, these alterations were not so market, in PL diets. Apart, there was any histological alteration in fish liver, neither in fish fed SO diets nor in those who ate PL diets.

In the growing experiment, FO was replaced by 50\% SO and PL to prevent any adverse effects in liver histology or organoleptic alteration. At the end of the experiment, there was no significant difference in final growth. Although, FO substitution by SO or PL increased the FCR values. As it was expected, pork lard and soybean oil affected fatty acids profile, but again it was observed that sharpsnout sea bream showed a lower fatty acid profile alteration in fish fillet, when they were fed with 50\% SO or PL diets. Through histology, it could be observed that liver of sharpsnout sea bream fed with FO and PL presented steatosis. Although, fatty acids were affected by lipid sources, it was observed through organoleptic test and trombogenicity and atherogenicity index that these fillets are healthy and not significant tasted alteration was detected by panelists. 


\section{ABREVIATURAS}

AA Aminoácidos

AC Aceite de canola

AC2 Aceite de colza

AAE Aminoácidos esenciales

AA CS Aminoácido que corresponde al cómputo químico

AG Ácidos grasos

AGE Ácidos grasos esenciales

AL Aceite de lino

AO Aceite de oliva

AP Aceite de pescado

Arg Arginina

AS Aceite de soja

CPA Concentrado proteico de alfalfa

CPG Concentrado proteico de guisante

CPS Concentrado proteico de soja

CS Cómputo Químico

DHA Acido docosahexaenoico

EPA Acido eicosapentaenoico

Fen Fenilalanina

GM Gluten de maíz

GP Grasa de pollo

GT Gluten de trigo

HA Harina de altramuz

HG Harina de guisante

His Histidina

HLD Lipoproteínas de alta densidad

HP Harina de pescado

HUFA Ácidos grasos altamente insaturados

IA Índice de aterogenicidad

IO Índice de Oser

Iso Isoleucina

IT Índice de trombogenicidad

LA Acido linoleico

LDL Lipoproteínas de baja densidad

Leu Leucina

Lis Lisina

LNA Acido linolenico

MC Manteca de cerdo

Met Metionina

MUFA Ácidos grasos monoinsaturados

MV Mezcla vegetal 


$\begin{array}{ll}\text { OA } & \text { Ácido oleico } \\ \text { PA } & \text { Ácido palmítico } \\ \text { PB } & \text { Proteína bruta } \\ \text { PCB } & \text { Bifenilo policlorado } \\ \text { PCDD } & \text { Dioxinas } \\ \text { PCDE } & \text { Éteres difenílicos policlorados } \\ \text { PUFA } & \text { Ácidos grasos poliinsaturados } \\ \text { RAA } & \text { Ratio Aminoacídico } \\ \text { SV } & \text { Sebo vacuno } \\ \text { SFA } & \text { Ácidos grasos saturados } \\ \text { TG } & \text { Turtó de girasol } \\ \text { Tre } & \text { Treonina } \\ \text { TS } & \text { Turtó de soja } \\ \text { VAL } & \text { Valina }\end{array}$


CAPÍTULO 1

\section{INTRODUCCIÓN GENERAL}





\section{CAPITULO 1. INTRODUCCIÓN GENERAL}

\subsection{UNA ESPECIE ALTERNATIVA PARA LA ACUICULTURA DEL MEDITERRANEO}

El incremento de la producción de la dorada y la lubina (unido a la entrada en el mercado español de dorada procedente de Grecia a precios muy bajos), ha provocado que los precios que en España, especialmente de la dorada, se hayan reducido hasta aproximarse a los costes de producción. Esto, ha llevado al sector a la búsqueda de especies alternativas para diversificar la producción, buscándose especies autóctonas, de fácil reproducción y con las que se puedan emplear las mismas infraestructuras ya existentes para la producción de la dorada y lubina. Una de las especies candidatas es el sargo picudo (Diplodus puntazzo, Cetti), ya que se trata de una especie de calidad similar a la dorada y que ha dado, en las primeras experiencias de producción, resultados lo suficientemente satisfactorios como para centrar la atención en la puesta a punto de las técnicas para su reproducción, producción larvaría (Faranda et al., 1985; Franicevic, 1989; Greco et al., 1993; Caggiano et al., 1993; Divanach et al., 1993; Micale et al., 1996; Marengos, 1995; Pastor et al., 2000), preengorde y engorde en producción intensiva en jaulas flotantes y tanques (Bermúdez et al., 1989; Kentouri et al., 1992; Abellán \& E García Alcazar, 1995; Gatland, 1995; García -García et al., 2001; García \& García, 2010). El sargo picudo es además una especie omnívora, la cual se alimenta de algas marinas como Caulerpa prolifera, Plocamium cartilagineum y plantas marinas como Cymodeocea spp, además de consumir gusanos, moluscos y langostinos (Sala \& Ballesteros, 1997; Mena Selles \& García-García, 2002), lo que a su vez la convertiría en una candidata ideal para compartir producción con la dorada como ya se ha visto en algunos trabajos de policultivo (Favaloro et al., 2002; Karakatsouli et al., 2006).

Otra característica interesante de esta especie es el período natural de puesta (octubre - diciembre), el cual se produce antes que el de la dorada (enero - marzo) y que la lubina (febrero -marzo), lo que permitiría optimizar la utilización de los criaderos (Marangos, 1995). De igual forma, la fecundidad del sargo picudo (Papadaki et al., 2008) es la más elevada de todas las especies de espáridos producidos en criaderos (2.5 - 5.0 millones de huevos $/ \mathrm{Kg}$.). Además, las técnicas empleadas para la producción 
de las larvas son similares a las utilizadas para la dorada (Franicevic, 1989; Abellán \& García Alcazar, 1995; Marangos, 1995).
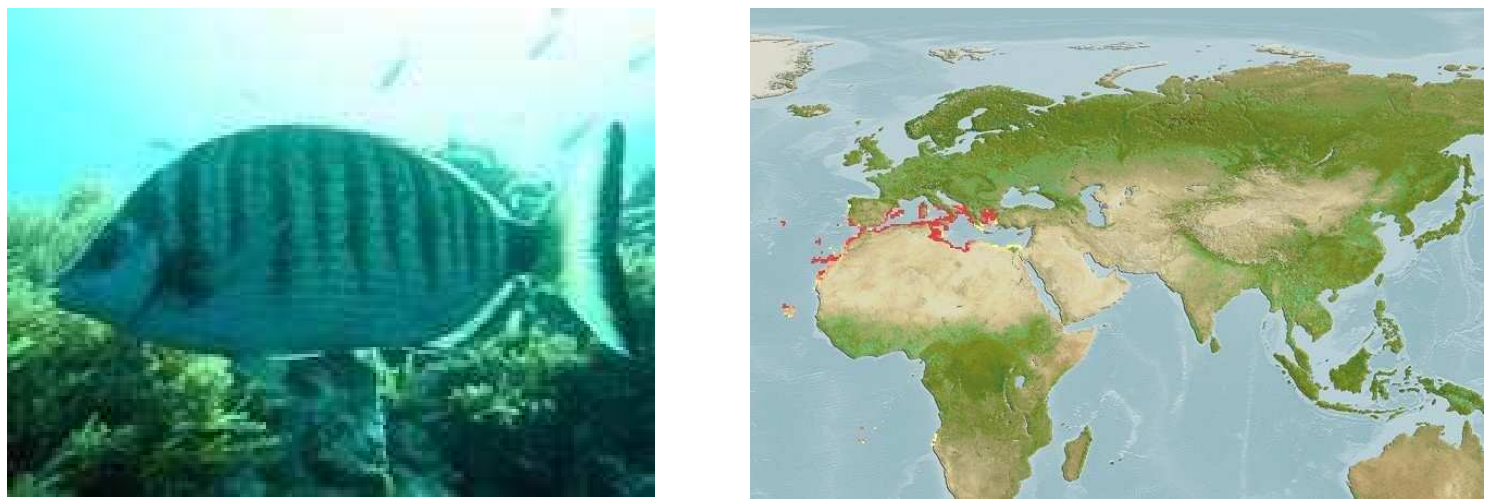

Figura 1. Fotografía del sargo picudo en su hábitat (www.mapa.es) y su distribución geográfica (www.fishbase.com)

Actualmente la producción de esta especie se da a pequeña escala (50 a 150 Tm. /año) en algunos países del Mediterráneo como Grecia, Italia, Turquía y Chipre y su interés en mejorar tanto aspectos nutricionales como los patológicos, así como las técnicas de producción, es constante en muchos de los países ribereños del mediterráneo: España, Francia, Grecia, Italia, Malta, Chipre y Túnez (Cardia \& Lovatelli, 2007; 2008). Desde el pre-engorde hasta el engorde, se han estado utilizando mayoritariamente piensos diseñados para dorada, que al ser una especie carnívora, presenta una mayor necesidad de materias primas de origen animal y un mayor porcentaje de proteína y lípidos, lo cual encarece los costes de producción. Asimismo, es sabido que el incremento de proteína en el alimento, generalmente incrementa el crecimiento hasta un punto en el que las necesidades de proteína exceden la capacidad del pez de sintetizar la proteína adicional. A este nivel cualquier proteína adicional es desaminada y convertida en energía (Wilson, 2002) o excretada en forma de amoniaco (Gatlin, 2010).

Se han realizado algunos estudios para determinar la necesidad nutricional del sargo picudo, la cual fluctuaría de acuerdo a la etapa de desarrollo del animal. En el caso de alevines, de entre 4 y 11 g, el nivel óptimo de proteína en el pienso estaría entre un 40 y 47\% y de lípidos entre un 8 y un 10\% (El-Ebiary, 2005; Torrejón Atienza et al., 2004). Para juveniles de sargo picudo (28 g), Bonaldo et al. (2004), ensayaron dos 
niveles proteicos (46.7 y 52.5\%) concluyendo que el mejor aprovechamiento proteico se daba con $46.7 \%$, atribuyendo este resultado en parte a que esta especie aprovecha mejor los carbohidratos dado que el pienso con mayor nivel proteico contenía menos carbohidratos, lo que incidió en un aumento de la ingesta. Por otra parte, para otra especie de Diplodus (D. sargus), se ha determinado que el nivel óptimo de proteína se encontraría entre 38 y 42\%, debido también a su hábito omnívoro (Sá et al., 2006), hábito alimenticio compartido con D. puntazzo. Por todo lo anteriormente mencionado, cabría esperar una respuesta óptima de crecimiento con un nivel proteico que fluctúe entre un 42 y $47 \%$.

\subsection{LAS HARINAS Y ACEITES DE PESCADO}

Las harinas y aceites de pescado han constituido tradicionalmente la base de la alimentación de las especies acuícolas hasta hace unas décadas, debido a que eran accesibles en precio, cantidad y calidad, presentando unas buenas digestibilidades en los peces. Sin embargo, su precio ha ido incrementándose con la demanda, especialmente dada por las economías emergentes como la de China, al igual que su producción ha disminuido en parte por anomalías atmosféricas como "El Niño", que produjo la disminución de captura del boquerón en Perú (www.fao.org). A esto, se ha asociado en las últimas décadas la posible contaminación de las harinas y el aceites de pescado por contaminantes orgánicos (PCB, PCDD, PCDF y pesticidas organohalogenados), lo que estaría produciendo pescado de crianza contaminado (Bell et al., 2005; Bell \& Waagbø, 2008, Turchini et al., 2009), amenazando de esta manera la producción acuícola. Por todo ello, se están buscando fuentes alternativas a las harinas y aceites de pescado, que compitan en calidad, precio y sostenibilidad.

\subsubsection{SUSTITUCIÓN DE LA HARINA DE PESCADO}

Los sustitutos parciales a las harinas de pescado que se han empleado hasta el momento son, por una parte harinas de origen animal, tales como harina de carne y hueso, harina de aves, harina de sangre y hemoglobina, harina de krill en especies marinas tales como la dorada y el fletan o eurihalinas como el salmón (Robaina et al., 1997; Nengas et al., 1999; Suontama et al., 2007; Martínez-Llorens et al., 2008; Hansen et al., 2010) o dulceacuícolas como la trucha o la perca americana (Bureau et al. 2000; 
Subhandra et al., 2006; Yoshitomi et al., 2006; 2007; Stone et al., 2008; Lee et al., 2010). También se han empleado harinas de organismos unicelulares tales como levaduras, algas, bacterias y hongos en especies marinas como la lubina (Oliva-Teles \& Gonçalves, 2001), el salmón (Storebakken et al., 2004; Berge et al., 2005; Aas et al., 2006), o en especies dulceacuícolas tales como el pacú y la trucha (Ozorio et al., 2009; Soler-Vila et al., 2009). Sin embargo, los mayores esfuerzos han estado dirigidos hacía la sustitución de la harina de pescado por fuentes vegetales en forma de harinas empleadas tanto para especies marinas como continentales (Furuya et al., 2000; Glencross et al., 2004; Pereira \& Oliva-Teles, 2002; 2004; Gomez-Requeni et al., 2004; De Francesco et al., 2004; 2007; Gill et al., 2006; Ogunkoya et al., 2006; Romarheim et al., 2006; Bonaldo et al., 2008; Emre et al., 2008; Davies \& Gouveia, 2008; Torstensen et al., 2008; Lim \& Lee, 2009; Li et al., 2009; Adamidou et al., 2009; Refstie et al., 2010), turtós o harinas desengrasadas (Bautista-Teruel et al., 2003; Tomás et al., 2005; Martínez-Llorens et al., 2007; 2009; Barrows et al., 2007; Sánchez-Lozano et al., 2007; Romarheim et al., 2008) y concentrados proteicos (Booth et al., 2001; Pereira \& Oliva-Teles, 2003; Refstie \& Tiekstra, 2003; Palmegiano et al., 2006; Drew et al., 2007; Takagi et al., 2008; Øverland et al., 2009; Kousoulaki et al., 2009; Sánchez-Lozano et al., 2009 y 2011; Salze et al., 2010; Pratoomyot et al., 2010; Penn et al., 2011), debido a su mayor disponibilidad y precios más estables.

En el sargo picudo se han realizado algunos trabajos sustituyendo parcialmente la harina de pescado por fuentes vegetales como la soja (Pastor et al., 2001; GarcíaGarcía et al., 2003; Hernández et al., 2007) con buenos resultados hasta con un $60 \%$ de sustitución, de igual forma se ha probado el concentrado proteico de alfalfa (CPA), (Chatzifotis et al., 2006), sin resultados positivos debido a la presencia de compuestos antinutricionales en el CPA y también posiblemente debido a un inadecuado perfil aminoacídico, dado que los peces como otros animales, no tienen una verdadera necesidad de proteína, pero sí tienen una necesidad de una mezcla equilibrada de aminoácidos esenciales (AAE) y de aminoácidos no esenciales (AANE). De acuerdo con Wilson (2002), esta necesidad fluctúa entre el 55\% y 30\%, dependiendo de la especie, la temperatura y la etapa de desarrollo de la misma. 
Debe existir un equilibrio entre los aminoácidos esenciales (AAE) y los no esenciales (AANE) en toda materia prima, para que exista un buen aprovechamiento de la proteína, ya que de acuerdo con Marcoulli et al. (2004) una alta proporción de AANE podrían afectar negativamente la eficiencia proteica, lo que podría ocasionar una reducción del crecimiento de los peces afectando a su vez a la salud del animal y un exceso sólo incrementaría la excreción de amoniaco (Gatlin, 2010). Asimismo, Wilson (2002), recomienda para especies marinas entre un 1 y 6\%, dependiendo del tipo de aminoácido, coincidiendo estos valores con los comentados por Tibaldi \& Kaushik (2003) para los espáridos, como lo muestra la Tabla 1.

Tabla l. Necesidades aminoacídicas para peces continentales y marinos y para espáridos, expresado en g/100 g proteína.

\begin{tabular}{lccccccccc}
\hline AAE & Arg & Fen & His & Iso & Leu & Lis & Met & Treo & Val \\
\hline $\begin{array}{l}\text { Continentales } \\
\text { y marinos }\end{array}$ & $2,9-6,0$ & $2,6-5,0$ & $1,2-2,5$ & $2,2-4,0$ & $3,3-5,3$ & $3,2-6,1$ & $1,6-4,0$ & $1,8-5,0$ & $2,2-4,0$ \\
\hline Espáridos & $3,8-5,4$ & $2,9-4,0$ & $1,2-1,7$ & 2,6 & $3,0-4,4$ & 5,0 & $2,1-2,4$ & $2.6-2,8$ & $2,8-3,0$ \\
\end{tabular}

Arg: Arginina; Fen: Fenilalanina; His: Histidina; Iso: Isoleucina; Leu: Leucina; Lis: Lisina; Met: Metionina; Treo; Treonina; Val: Valina. Wilson (2002); Tibaldi \& Kaushik (2003).

Si se considera el perfil aminoacídico propuesto por Wilson (2002) y se toma como base la harina de pescado como fuente ideal para la alimentación de peces, se puede observar que la mayoría de las harinas vegetales empleadas para la acuicultura presentarían deficiencias en algunos $\mathrm{AAE}$, como es el caso de la harina de guisante y altramuz y el turtó de soja y girasol, que presentan deficiencias en la mayoría de los AAE (Figura 2), por lo cual la sustitución total de la harina de pescado por éstas estaría muy limitada. Sólo los concentrados proteicos podrían sustituir en mayor proporción a la harina de pescado, de forma individual, aunque requerirían la suplementación de algunos AAE, como el caso del concentrado proteico de guisante (CPG) que es deficiente en metionina o el turtó de girasol (TG) que es deficiente en metionina y lisina respecto a la harina de pescado. 


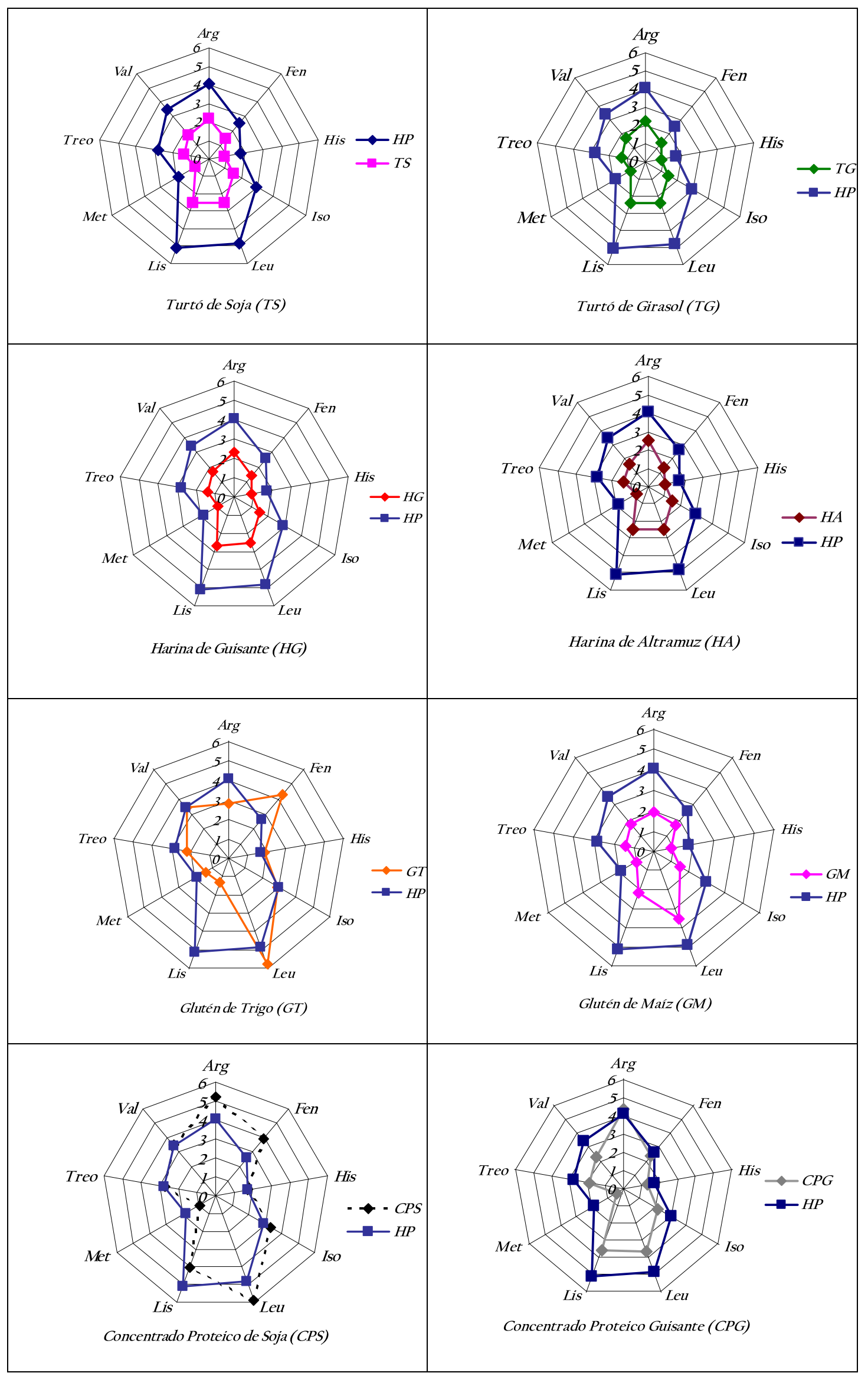

Figura 2. Perfil de aminoácidos esenciales de algunas fuentes vegetales expresados en g/100 g muestra comparada con la harina de pescado. 
HP (Harina de pescado); TS (Turtó de soja); TG (Turtó de girasol); HG (Harina de guisante); CPG (Concentrado proteico de guisante); HA (Harina de altramuz); GT (Gluten de trigo); CPS (Concentrado proteico de soja).

Por otra parte, estas fuentes vegetales poseen un alto contenido en carbohidratos, especialmente las harinas y en menor medida los turtós, que en el caso de emplearse en especies carnívoras reduciría su aprovechamiento. En las especies omnívoras y herbívoras, las cuales poseen enzimas digestivas tales como la amilasa, la maltasa y la celulasa presentes en el tracto digestivo del sargo picudo (Tramati et al., 2005; Savona et al., 2011), les permitirían aprovechar mejor los carbohidratos como fuente energética, permitiendo reducir el nivel lipídico en el alimento.

Otro aspecto a tener en cuenta en toda fuente alternativa a la harina de pescado, aparte de un adecuado contenido proteico y/o perfil aminoacídico, es también la palatabilidad, ya que ésta es la suma de muchas características dietéticas y que además existe una fuerte interacción entre el sabor y la calidad nutricional del alimento (Gatlin et al., 2007) El efecto negativo sobre la palatabilidad de las materias primas se ha observado en doradas alimentadas con harinas y concentrados proteicos vegetales, produciendo un descenso en los índices de crecimiento a medida que se incrementaba la inclusión de estas fuentes vegetales (Kissil et al., 2000; Gómez-Requeni et al., 2004; Sitjà-Bobadilla et al., 2005)

Dentro de las fuentes vegetales existentes en el mercado se ha considerado al Turtó de Girasol (TG) como una fuente vegetal alternativa no sólo por su abundancia en el mercado y precio asequible, sino también por la palatabilidad de esta materia prima y los resultados obtenidos en algunos trabajos realizados tanto con especies marinas como la dorada (Sánchez-Lozano et al., 2007) o el salmón (Aslaksen et al., 2007; Gill et al., 2006), en la trucha (Martínez, 1984), o especies omnívoras y dulceacuícolas como la tilapia (Maina et al., 2003; Olvera-Novoa et al., 2002; Furuya et al., 2000). Todos estos trabajos apuntan un máximo nivel de inclusión de la fuente vegetal entre el 12 y $15 \%$, debido al alto contenido en fibra y carbohidratos del girasol.

Otra materia prima cuyo potencial ha sido poco estudiado, especialmente en la acuicultura, es el Concentrado Proteico de Guisante (CPG) el cual posee un alto 
contenido proteico y buen perfil de aminoácidos, aunque es deficiente en metionina. Existen algunos trabajos realizados en especies marinas como la dorada (SánchezLozano et al., 2011), el salmón (Overland et al., 2009) o continentales como el pez gato (Clarias gariepinus) (Davies \& Gouveia, 2008) y la tilapia (Schulz et al., 2007) en los que se ha probado el CPG como única fuente proteica alternativa a la harina de pescado. También se ha empleado combinándola con otras fuentes vegetales como en el caso de la dorada alimentada con una mezcla de CPG y concentrado proteico de arroz (Sánchez-Lozano et al., 2009) o la misma especie alimentada con un combinado de CPG con gluten de trigo y maíz (Días et al., 2009). De igual forma, existen trabajos en salmón alimentado con una combinación de CPG y concentrado proteico de altramuz (Carter \& Hauler, 2000) o en el caso de la tilapia nilótica alimentada con una mezcla de CPG, gluten de maíz, concentrado proteico de canola y linaza decorticada (Borgeson et al., 2006). En los trabajos anteriormente mencionados, se realizaron sustituciones de hasta un $100 \%$ en el caso de combinaciones y un 60\% en el caso de emplear al CPG como única fuente vegetal alternativa. A partir de un 40\% de sustitución de la HP por CPG ya se han encontrado diferencias en el crecimiento, pero en especies omnívoras como la tilapias sólo hubo diferencias a partir de un 60\% de sustitución. En las mezclas vegetales se han obtenido crecimientos similares el pienso control hasta con un $60 \%$ de inclusión para especies carnívoras como la dorada.

\subsection{NECESIDADES LIPÍDICA Y DE ÁCIDOS GRASOS EN LOS PECES MARINOS}

Los lípidos son componentes importantes del pienso de los peces, especialmente el aceite de pescado, porque proveen una fuente de energía concentrada que es normalmente bien utilizada, además aporta ácidos grasos esenciales (AGE), y es una fuente muy rica de vitaminas liposolubles (A, D) (Halver, 2002). De igual forma, los aceites marinos que contienen ácidos grasos altamente insaturados (HUFA) de la series n-3, tal como el ácido eicosapentaenoico (EPA, 20:5n-3) y el ácido docosahexaenoico (DHA, 22:6n-3), satisfacen las necesidades en AGE a los peces marinos, dada la limitada capacidad de éstos para elongar y desaturar cadenas de ácidos grasos más cortas en comparación con las especies continentales (Turchini et al., 2009). Las necesidades en n-3 HUFA generalmente han sido estimadas en un 10 a un 20\% de los lípidos del pienso. De igual forma se ha visto que algunas especies marinas también pueden tener una necesidad específica para el ácido araquidónico (ARA, 20:4n-6) 
(Gatlin, 2000). Esta necesidad de n-3 HUFA, está dada por el hecho de que a baja temperatura, el mantenimiento de la vida exige la permeabilidad de las membranas celulares y de la fase fosfolipídica de ciertas enzimas y el alto grado de insaturación de los AG satisface esta exigencia. Por otra parte, las especies marinas desarrollan su vida en un medio ambiente acuático con temperaturas relativamente bajas y poco variables, por lo tanto la insaturación de los AG constituye el soporte nutricional y estructural de la poiquilotermia (Kinkelin et al., 1991).

Los ácidos grasos poli-insaturados son casi exclusivamente sintetizados por las plantas. Los animales pueden convertir de una forma de ácidos grasos poliinsaturados (PUFA) a otra a través de la elongación y desaturación, pero muy pocos pueden sintetizar de novo. Los PUFAS no son primariamente empleados como fuente de energía, de hecho se sugiere que ciertos tipos de PUFAS, en especial el ARA, afectan a la fisiología animal a través de su impacto en la fluidez de la membrana celular y la producción de eicosanoides, los cuales incluyen las prostaglandinas, tromboxanos, leucotrienos, ácidos grasos (AG) hidróxidos y lipoxilenos, los cuales afectan a un amplio rango de procesos fisiológicos como la supervivencia, crecimiento, conversión alimenticia, fecundidad, eclosión de huevos, y la tolerancia al estrés osmótico (Brett et al., 1997).

De igual forma Glencross (2009) indica, que el origen medio ambiental de las especies (de agua dulce, estuario o marinas) parece ser el factor primario, que influye en las diferentes necesidades de ácidos grasos esenciales.

\subsubsection{SUSTITUCIÓN DEL ACEITE DE PESCADO}

El aceite de pescado ha sido sustituido principalmente por aceites de origen vegetal tales como soja, aceite de palma, colza, lino y girasol en especies tanto marinas, como la dorada (Izquierdo et al., 2003; 2005; Montero et al., 2003; 2008; MartínezLlorens et al., 2007; Fountoulaki et al., 2009; Benedito-Palos et al., 2009; 2010; Ganga et al., 2011), el sargo picudo (Almaida-Pagán et al., 2007; Piedecausa et al., 2007), dorada del Pacífico (Glencross et al., 2003), la lubina (Mourete et al., 2005; Richard et al., 2006), el bacalao del Atlántico (Mørkøre et al., 2007), el pargo negro (Peng et al., 2008) así como 
en especies eurihalinas, tales como el salmón (Grisdale-Helland et al., 2002; Ruyter et al., 2006; Aslaksen et al., 2007; Olsvik et al., 2007; Pratoomyot et al., 2008; Turchini et al., 2003; 2011) o en especies continentales como el bagre (Ng et al., 2000), la tilapia (Ng \& Wang, 2011; Teoh et al., 2011), la perca de Murray (Francis et al., 2007) y el pacú (Tanamati et al., 2009).

Estas materias primas han sido muy utilizadas por su abundancia en el mercado y sus precios bajos en comparación con el aceite de pescado. Sin embargo, en los últimos años como consecuencia del auge de los biocombustibles, el precio de estas materias primas se ha incrementado, especialmente el del aceite de soja.

De igual forma, se han empleado grasas animales tales como la manteca, el sebo y la grasa de pollo tanto en especies marinas (Mugrditchian et al., 1981; Craig \& Gatlin, 1995; Xue et al., 2006; Martins et al., 2009; Wang et al., 2011), como continentales (Heck \& Calbert, 1977; Martino et al., 2002; Turchini et al., 2003; Liu et al., 2004; Zhou et al., 2007; 2010; Noffs et al., 2009; Regan et al., 2010) para reemplazar parcialmente el aceite de pescado.

Tanto las grasas animales como las vegetales son deficientes en ácidos grasos poliinsaturados, especialmente en los llamados omega-3 y ricos en omega-6 y omega9, como se muestra en la Tabla 2. No obstante en el caso de las grasas animales, el contenido de los diferentes ácidos grasos estaría en función del tipo de alimentación recibida, y en el caso de los aceites vegetales, de su procedencia. 
Tabla 2. Ácidos grasos de las fuentes lipídicas más empleadas en acuicultura, expresado en porcentaje de área.

\begin{tabular}{|c|c|c|c|c|c|c|c|c|}
\hline $\begin{array}{l}\text { FUENTES } \\
\text { LIPIDICAS }\end{array}$ & $S F A$ & MUFA & $L A$ & $A R A$ & $L N A$ & $E P A$ & $\overline{D H A}$ & $n 3 / n 6$ \\
\hline A. bacalao* & 19,4 & 46,0 & 1,4 & 1,6 & 0,6 & 11,2 & 12,6 & 9,0 \\
\hline A. capelin ${ }^{\omega}$ & 20,0 & 62,0 & 2,0 & - & 1,0 & 5,0 & 3,0 & 2,2 \\
\hline A. palma* & 48,8 & 37,0 & 9,1 & - & 0,2 & - & - & 0,0 \\
\hline A. soja* & 14,2 & 23,2 & 51,0 & - & 6,8 & - & - & 0,1 \\
\hline A. soja ${ }^{\dagger}$ & 15,7 & 24,2 & 52,1 & - & 7,8 & - & - & 0,1 \\
\hline A. soja ${ }^{\ddagger}$ & 12,8 & 24,7 & 46,8 & 0,1 & 0,6 & - & - & - \\
\hline A. canola* & 4,6 & 62,3 & 20,2 & - & 12,0 & - & - & 0,6 \\
\hline A. girasol* & 10,4 & 19,5 & 65,7 & - & - & - & - & 0,0 \\
\hline A. algodón* & 45,3 & 17,8 & 51,5 & - & 0,2 & - & - & 0,0 \\
\hline A. maíz* & 12,7 & 24,2 & 58,0 & - & 0,7 & - & - & 0,0 \\
\hline A. $\operatorname{lino} 0^{*}$ & 9,4 & 20,2 & 12,7 & - & 53,3 & - & - & 4,2 \\
\hline Sebo vacuno* & 47,5 & 40,5 & 3,1 & 0,4 & 0,6 & - & - & 0,2 \\
\hline Mant. Cerdo* & 38,6 & 44,0 & 10,2 & - & 1,0 & - & - & 0,1 \\
\hline Mant. Cerdo ${ }^{\omega}$ & 39,0 & 45,0 & 10,0 & - & 1,0 & - & - & 0,1 \\
\hline Mant. Cerdo ${ }^{\dagger}$ & - & - & 8,6 & 1,1 & 1,0 & - & - & 0,1 \\
\hline Grasa pollo* & 28,5 & 43,1 & 19,5 & - & 1,0 & - & - & 0,0 \\
\hline
\end{tabular}

SFA: Ácidos grasos saturados; MUFA: Ácidos grasos mono-insaturados; LA: Ácido linoléico; ARA: Ácido araquidónico; LNA: Ácido linolénico; EPA: Ácido eicosapentanoico; DHA: Ácido docohexaenoico.

* Turchini et al. (2009).

${ }^{\oplus}$ Glencross (2009).

${ }^{\dagger}$ Benatti et al. (2004).

${ }^{\ddagger}$ Dubois et al. (2007)

Como se observa en la Tabla 2, los aceites de origen vegetal y la mayoría de grasas de animales carecen de los ácidos grasos del tipo omega 3 (EPA y DHA), sólo el cebo vacuno y la manteca de cerdo contendrían ARA (Benatti et al., 2004; Turchini et al., 2009) no así EPA ni DHA, los cuales son esenciales para las especies marinas como el sargo picudo, por lo que la sustitución del aceite de pescado por fuentes lipídicas tanto vegetales como animales ha sido parcial en la mayoría de los casos.

Se ha empleado el aceite de soja (AS) para sustituir al aceite de pescado (AP) en la alimentación de espáridos carnívoros como la dorada (Izquierdo et al., 2003; Martínez-Llorens et al., 2007; Montero et al., 2008; Benedito-Palos et al., 2008), o como el pargo negro, Acanthopagurs schlegelii, (Peng et al., 2008), la dorada del Pacífico, Pagrus auratus, (Glencross et al., 2003), encontrándose diferencias significativas en el crecimiento y eficiencia alimenticia en el caso de la doradas en fase de pre-engorde, a partir del 60\% de sustitución y en el engorde, a partir del 30 - 48\% de sustitución. No obstante, en el caso de la dorada del Pacífico, no encontraron diferencias con el 100\% de sustitución en pre-engorde, de igual forma, en el pargo negro, sólo indican diferencias a 
partir del 80\% de sustitución en animales en fase de engorde. En P. auratus sólo encontraron diferencias significativas en el 100\% de sustitución por aceite de canola sin refinar en animales de pre-engorde, aunque en todas estas especies, se señalaban diferencias significativas en el contenido de EPA y DHA hasta con la mínima sustitución de aceite de pescado (AP) por aceite de soja (AS). Sin embargo, en el sargo picudo, Piedecausa et al. (2007) no indicaban diferencias en los parámetros de crecimiento y eficiencia alimentaria con el 100\% de sustitución, aunque estos mismos autores y Almaida-Pagán et al. (2007) sí observaron diferencias estadísticas en el perfil de AGE con la sustitución total del AP por AS.

Por otra parte, la sustitución del aceite de pescado por grasas animales sólo se ha realizado en especies carnívoras como el serránido japonés, Lateolabrax japonicus (Xue et al., 2006), la trucha arco iris (Caballero et al., 2002; Liu et al., 2004), la anguila del arroz, Monopterus albus (Zhou et al., 2010), y el surubí, Pseudoplatystoma coruscans, (Martino et al., 2002; Noffs et al., 2009). En especies marinas o eurihalinas como el serránido japonés o la trucha arco iris se ha sustituido hasta un $70 \%$ el AP por grasas animales, sin mostrar diferencias significativas en el crecimiento y en la eficiencia alimentaría, no obstante en especies continentales se ha llegado a remplazar hasta un 100\% sin encontrar diferencias en el crecimiento. Aunque, en el caso del surubí, hay controversia, ya que Martino et al. (2002) no observaron diferencias en el contenido en ARA, EPA y DHA, sin embargo, Noffs et al. (2009) si obtuvieron diferencias significativas, al igual que en la anguila del arroz, Zhou et al. (2010).

La sustitución del aceite de pescado por una fuente lipídica alternativa, ya sea vegetal como animal, no sólo afecta el crecimiento y a la eficiencia alimentaria de los peces, sino que a la vez afecta y de forma muy importante, como indican Turchini et al. (2009), al porcentaje de ácidos grasos a nivel corporal del animal dependerá de su capacidad para bio sintetizar dichos ácidos grasos y del pienso que están consumiendo. Por otra parte, se han observado alteraciones histológicas causadas por la sustitución del aceite de pescado por las fuentes lipídicas alternativas tanto en especies marinas o eurihalinas (Caballero et al., 2002; Figuereido-Silva et al., 2005; Ruyter et al., 2006; Wassef et al., 2007) como en especies continentales (Kowalska et al., 2009). 


\subsection{ALTERACIONES DEL HÍGADO E INTESTINO DE LOS PECES PRODUCIDOS POR LA ALIMENTACIÓN.}

La búsqueda de materias primas alternativas a las harinas y aceites de pescado no debe hacer olvidar un aspecto importante a la hora de evaluarla, no sólo en base a los índices de crecimiento y eficiencia nutritiva, sino como éstas pueden afectar la salud del animal, lo cual se puede valorar a través de la histología digestiva.

De acuerdo con Roberts (1981) el hígado de los teleósteos tiene un considerable volumen en relación al cuerpo, es de color marrón rojizo en las especies libres carnívoras y marrón claro en las especies herbívoras, pero en ciertas épocas del año podría ser de color amarillo e incluso blanquecino. Los peces de piscifactoría suelen presentar un color más claro que los de su misma especie de vida libre.

El hígado puede encontrarse a lo largo del abdomen o estrechamente unido a otras vísceras. Pero en algunas especies se encuentra combinado con el páncreas formando el hepatopáncreas (Ferguson, 1989) (Fig. 3) como es el caso del sargo picudo. Los hepatocitos son poligonales y tienen un núcleo central claramente visible con bordes intensamente teñidos de cromatina y con un prominente nucleolo, a menudo llenos de glucógeno o grasa neutra cuando la alimentación es suficiente o está en el límite de sus necesidades. Dentro del hígado también se suelen encontrar células de almacenamiento de grasa conocidas como células de Ito, que es el sitio de almacenamiento de la vitamina A (Sakano \& Fujita, 1982; Fujita et al., 1986; Wake et al., 1987; Robertson \& Bradley, 1992). 


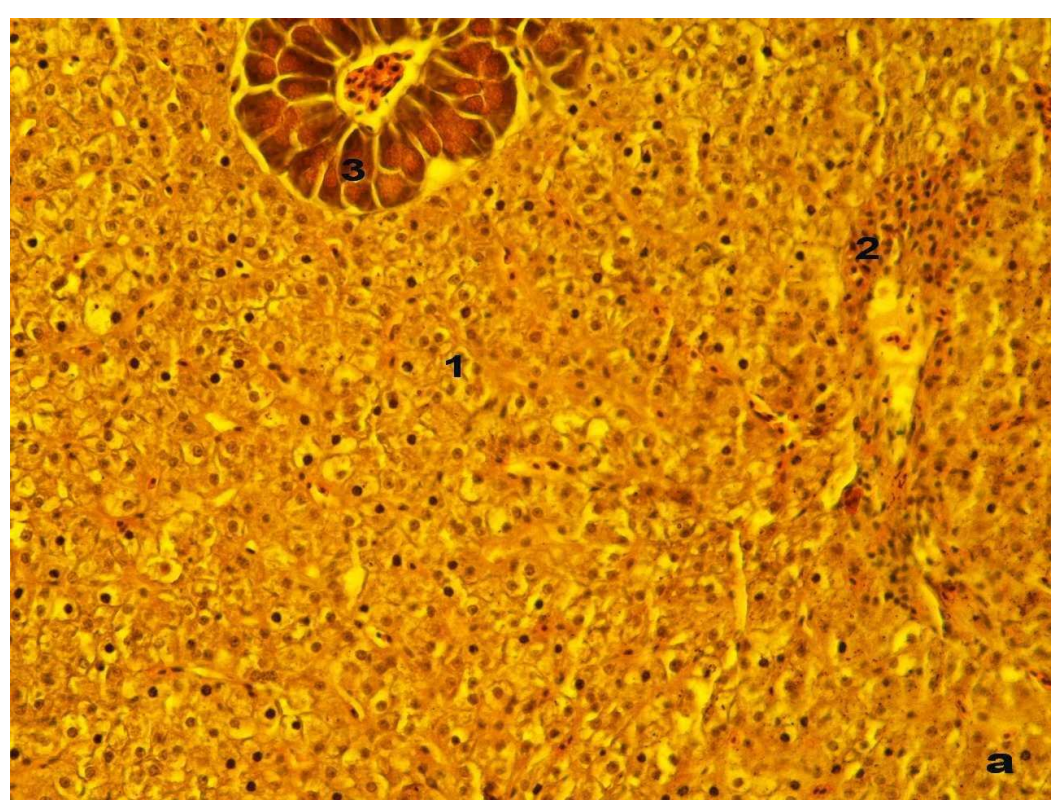

Figura 3. Corte transversal del hepatopáncreas de D. puntazzo (1: hepatocitos; 2: eritrocitos; 3: células acinares)

Algunos autores han encontrado alteraciones hepáticas atribuidas a la sustitución de harina o aceite de pescado por fuentes proteicas vegetales (Pereira et al., 2002; Catacutan \&E Pagador, 2004; Sitjà-Bobadilla et al., 2005; Escaffre et al., 2007) o aceites vegetales (Rodríguez et al., 2005; Ruyter et al., 2006; Wassef et al., 2007; Fountoulaki et al., 2009) o por efecto de la inclusión de carbohidratos en algunas especies carnívoras (Russell et al., 2001; Tan et al., 2006). Entre las alteraciones, se encuentran la acumulación de gotas lipídicas intracelulares, glucógeno, necrosis celular y esteatosis. No obstante, cabe destacar que el hígado de los peces tiene la capacidad de regenerar el parénquima hepático después de la destrucción debido a sustancias tóxicas (Ross et al., 1989).

En el caso del intestino, se extiende desde el final de la región pilórica del estomago hasta el ano e incluye el duodeno, intestino anterior, intestino posterior y recto. No obstante, en algunas especies es difícil diferenciar las tres regiones por lo que se suelen llamar colectivamente intestino (Hibiya, 1982). El intestino suele presentar dos tipos de vellosidades; las vellosidades simples (Fig. 4a) y las vellosidades ramificadas (Fig. 4b) (Daprà et al., 2009). 

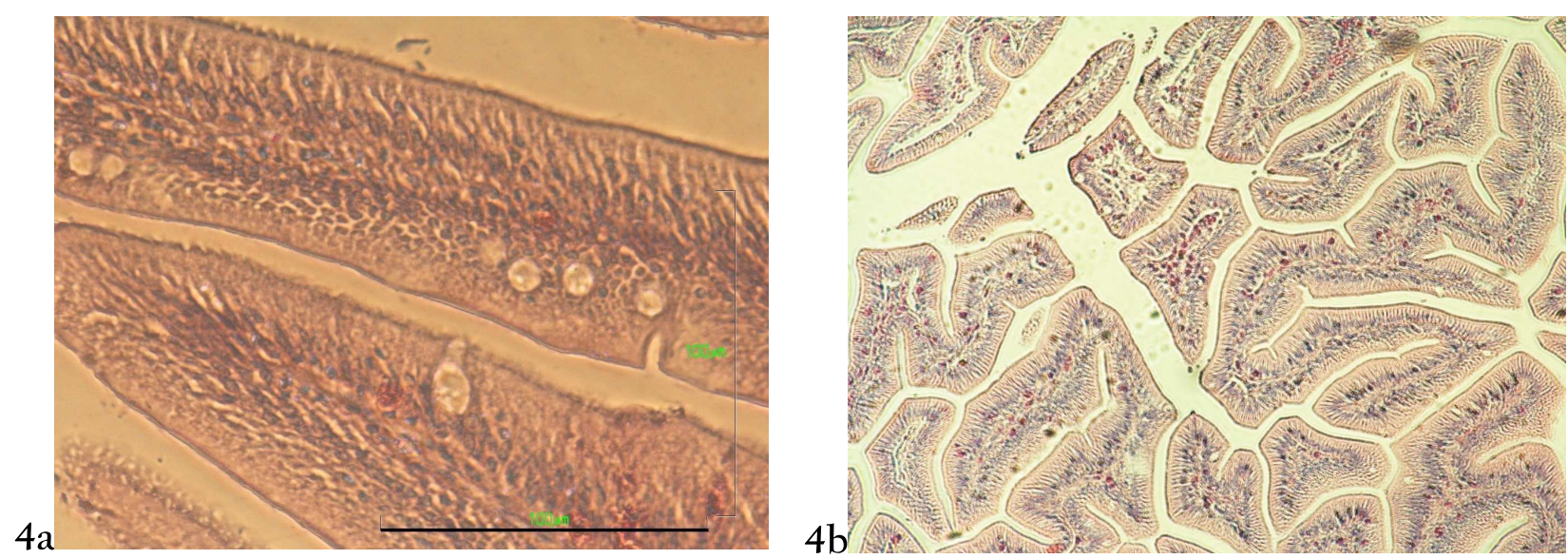

Figura 4 Cortes histológicos del intestino. (a) Porción intermedia del intestino del sargo picudo. (b) Porción posterior del intestino.

Al igual que en el hígado, se han estudiado los efectos de la sustitución parcial o total de la harina y el aceite de pescado por fuentes vegetales y animales principalmente en especies carnívoras como la trucha, salmón o dorada, comprobando que dichas fuentes causan alteraciones en el intestino de los peces: acumulación de gotas lipídicas en los enterocitos, elongación de las vellosidades, proliferación de macrófagos, aumento de células mucosas hasta la enteritis (Baeverfjord \& Krogdahl, 1996; Caballero et al., 2003; Olsen et al., 2003; 2007; Suzuki \& Yamamoto, 2004; Bakke-McKellep et al., 2007; Bonaldo et al., 2006; 2008; Sealey et al., 2009; Refstie et al., 2010 entre otros), lo cual afecta directamente al aprovechamiento del alimento y por ende al crecimiento. En algunos casos, como una respuesta adaptativa del animal al nuevo alimento para mejorar su absorción y en otros casos, como una respuesta inmunológica ante la presencia de algunas sustancias antinutricionales o nocivas que afectan no sólo la absorción del alimento sino el bienestar del animal.

\subsection{CALIDAD NUTRICIONAL DE LA CARNE}

Y por último y no menos importante, la finalidad de toda producción o crianza de animales es el ofrecer un alimento de alto valor nutritivo, como es el caso del pescado, especialmente el marino, cuyos contenido en ácidos grasos poliinsaturados (EPA, DHA, ARA) lo ha colocado dentro de los alimentos prioritarios para una buena alimentación humana. Así, la sustitución del aceite y harina de pescado en la alimentación de especies acuícolas ha dado como resultado una modificación inevitable en la composición de los ácidos grasos del filete del pescado, y la consecuente pérdida 
de las características particulares asociadas a la mejora de la salud por el consumo del pescado y los alimentos marinos. Dado que el perfil de ácidos grasos no sólo está influenciado por el alimento, sino la especies, su hábito alimenticio (herbívoro, omnívoro o carnívoro) y su hábitat (continental o marino), por lo que los peces pueden llegar a tener una menor o mayor capacidad de bioconvertir parte de los AG de su alimento en AGE, especialmente HUFAS (Turchini et al., 2009) modificando estos AG en beneficio no sólo del animal, sino del ser humano que es el objeto de toda producción acuícola.

Estas modificaciones además pueden afectar la calidad sensorial de los filetes de pescado y la percepción que tiene el consumidor del pescado de crianza (Turchini et al., 2009), como en el caso del sargo picudo alimentado con un 60\% de TS que presentó una alteración en la textura (Hernández et al., 2007), o la modificación del sabor y olor de los filetes de las doradas alimentadas con un $40 \%$ de AS (Izquierdo et al., 2005), o como el caso de las doradas alimentadas con un $80 \%$ de AS, cuyos filetes eran más jugosos, aunque con un sabor terroso (Izquierdo et al., 2005). Asimismo, Martínez-Llorens et al. (2007), indicaban diferencias en la textura entre los peces alimentados con AP y las doradas alimentadas con un $72 \%$ de AS, presentando las primeras, filetes más grasos, suaves, pegajosos y menos duros que los peces alimentados con AS.

Sin embargo, hay casos en los que las sustituciones no han afectado la calidad organoléptica (Fountoulakis et al., 2009). Estos autores encontraron que no hubo diferencias entre doradas alimentas con AP y aquellas alimentadas con aceites vegetales, aunque destacaron que en general los filetes tuvieron una baja aceptación. Este hecho podría ser debido a que las doradas de piscifactoría presentan un mayor contenido de grasa muscular y menor humedad en comparación con las salvajes (Grigorakis, 2007). Como consecuencia de una reducción de la natación y un pienso inadecuado, produciendo un aumento de la grasa peri visceral y del tamaño del hígado, como indican Favaloro et al. (2002) y Favaloro \& Mazzola (2003). Los peces salvajes suelen ser más delgados que los peces de piscifactoría (Lie, 2001).

De igual forma es importante recordar que los peces son una excelente fuente de proteína y de AGE como los $\omega 3$, por otra parte, los lípidos de los peces son una fuente de vitamina D y en general proveen también un número de vitaminas del complejo B, así 
como minerales y otros oligoelementos (Lie, 2001), por lo que la calidad nutricional de los filetes juega cada vez más un rol importante en la alimentación y salud humana.

Por todo lo anteriormente mencionado y teniendo en cuenta los estudios de Hernández et al. (2001) y García-García et al. (2008), en los cuales se indica que el sargo picudo es una especie con una buena aceptación por parte de la población encuestada, si esta especie estuviera disponible en los distintos mercados a un precio razonable, acompañada de una campaña de consumo, podría formar parte de la cesta de compra como lo es la dorada, aunque a un mejor precio y calidad. Dicho precio razonable, podría darse si se emplean fuentes proteicas o lipídicas alternativas que reduzcan los costes de producción y que a la vez ofrezcan al consumidor un producto de calidad tanto a nivel organoléptico como nutricional.

\subsection{BIBLIOGRAFÍA}

Aas, T.S., Grisdale-Helland, B., Terjesen, B.F., Helland, S.J. (2006) Improved growth and nutrient utilisation in Atlantic salmon (Salmo salar) fed diets containing a bacterial protein meal. Aquaculture, 259: 365 - 376.

Abellán, E., García Alcazar, A. (1995) Pre-growout and growout experiences with White seabrea (Diplodus sargus sargus, Linnaeus, 1758) and sharpsnout seabream (Diplodus puntazzo, Cetti 1777). Cahier Option Mediterránnées, 16: 57 - 63.

Adamidou, S., Nengas, I., Alexis, M., Foundoulaki, E., Nikolopoulou, D., Campbell, P., Karacostas, I., Rigos, G., Bell, G.J., Jauncey, K. (2009) Apparent nutrient digestibility and gastrointestinal evacuation time in European seabass (Dicentrarchus labrax) fed diets containing different levels of legumes. Aquaculture, 289: 106 - 112.

Almaida-Pagán, P.F., Hernández, M.D., García-García, B., Madrid, J.A., De Costa, J., Mendiola, P. (2007) Effect of total replacement of fish oil by vegetable oil son $n-3$ and $n-6$ polyunsaturated fatty acid desaturation and elongation in sharpsnout seabream (Diplodus puntazzo) hepatocytes and enterocytes. Aquaculture, 272: 589 - 598.

Aslaksen, M.A., Kraugerud, O.F., Penn, M., Svihus, B., Denstadli, V., Jørgensen, H.Y., Hillestad, M., Krogdahl, Å., Storebakken, T. (2007) Screening of nutrient digestibilities and intestinal pathologies in Atlantic salmon, Salmo salar, fed diets with legumes, oilseeds or cereals. Aquaculture, 272: 541 - 555.

Baeverfjord, G., Krogdahl, Å. (1996) Development and regression of soybean meal induced enteritis in Atlantic salmon, Salmo salar L., distal intestine: a comparison with the intestines of fasten fish. Journal of Fish Disease, 19: 375 - 387. 
Bakke-McKellep, A.M., Koppang, E.O., Gunnes, G., Sanden, M., Hemre, G-I., Landsverk, T., Krogdahl, Å. (2007) Histological, digestive, metabolic, hormonal and some immune factor responses in Atlantic salmon, Salmo salar fed genetically modified soybeans. Journal of Fish Diseases, 30: 65 79.

Barrows, F.T., Stone, D.A.J., Hardy, R.W. (2007) The effects of extrusion conditions on the nutritional value of soybean meal for rainbow trout (Oncorhynchus mykiss). Aquaculture, 265: 244 - 252.

Bautista-Teruel, M.N., Fermin, A.C., Kosie, S.S. (2003) Diet development and evaluation for juvenile abalone, Haliotis asinina: animal and plant protein sources. Aquaculture, 219: 645 - 653.

Bell, J.G., McGhee, F., Dick, J.R., Tocher, D.R. (2005) Dioxin and dioxin-like polychlorinated biphenyls (PCBs) in Scottish farmed salmon (Salmo salar): effects of replacement of dietary marine fish oil with vegetable oils. Aquaculture, 243: 305 - 314 .

Bell, J.G., Waagbø, R. (2008) Safe and Nutritious Aquaculture Produce: Benefits and Risks of Alternative Sustainable Aquafeeds. In: Aquaculture in the Ecosystem. (Holmer et al. (Eds)). Springer, Bergen, Norway. 185 - 225 pp.

Benedito-Palos, L., Navarro, J.C., Sitjà-Bobadilla, A., Bell, G., Kaushik, S., Pérez-Sánchez, J. (2008) High levels of vegetable oils in plant protein - rich diets fed to gilthead sea bream (Sparus aurata L.): growth performance, muscle fatty acid profiles and histological alterations of target tissues. British Journal of Nutrition, 100: 992 - 1003.

Benedito-Palos, L., Navarro, J.C., Bermejo-Nogales, A., Saera-Vila, A., Kaushik, S., Pérez-Sánchez, J. (2009) The time course of fish oil wash-out follows a simple dilution model in gilthead sea bream (Sparus aurata L.) fed graded levels of vegetable oils. Aquaculture, 288: 98 - 105.

Benedito-Palos, L., Navarro, J.C., Kaushik, S., Pérez-Sánchez, J. (2010) Tissue-specific robustness of fatty acid signatures in cultured gilthead sea bream (Sparus aurata L.) fed practical diets with a combined high replacement of fish meal and fish oil. Journal of Animal Science, 88: 1759 - 1770.

Benatti, P., Peluso, G., Nicolai, R., Calvani, M. (2004) Polyunsaturaed Fatty Acids: Biochemical, Nutritional and Epigenetic Properties. Journal of the American College of Nutrition, 23: 281 302.

Berge, G., Baeverfjord, G., Skrede, A., Storebakken, T. (2005) Bacterial protein growth on natural gas as protein source in diets for Atlantic salmon, Salmo salar, in saltwater. Aquaculture, 244: 233 - 240.

Bermúdez, L., García-Gacría, B., Gómez, O., Rosique, M.J., Faraco, F. (1989) First results of the ongrowing in cages of Sparus aurata, Puntazzo puntazzo, and Lithognatus mormirus in the Mar Menor (Murcia, SE, Spain). EAS Special Publication, 10: 27 - 28.

Bonaldo, A., Rizzi, L., Badiani, A., Testi, S., Gatta, P.P. (2004) Growth response and body composition of sharpsnout sea bream (Diplodus puntazzo) fed a high energy diet with different protein levels. Italian Journal of Animal Science, 3: 235 - 242.

Bonaldo, A., Roem, A.J., Pecchini, A., Grilli, E., Gatta, P.P. (2006) Influence of dietary soybean meal levels on growth, feed utilization and gut histology of Egyptian sole (Solea aegyptiaca) juveniles. Aquaculture, 261: 580 - 586. 
Bonaldo, A., Roem, A.J., Fagioli, P., Pecchini, A., Cipollini, I., Gatta P.P. (2008) Influence of dietary levels of soybean meal on the performance and gut histology of gilthead sea bream (Sparus aurata L.) and European sea bass (Dicentrarchus labrax L.) Aquaculture Research, 39: 970 - 978.

Borgeson, T.L., Racz, V.J., Wilkie, D.C., White, L.J., Drew, M.D. (2006) Effect of replacing fishmeal and oil with simple or complex mixtures of vegetable ingredients in diets fed to Nile tilapia (Oreochromis niloticus). Aquaculture Nutrition, 12: 141 - 149.

Booth, M.A., Allan, G.L., Frances, J., Parkinson, S. (2001) Replacement of fish meal in diets for Australian silver perch, Bidyanus bidyanus IV. Effects of dehulling and protein concentration on digestibility of grain legumes. Aquaculture, 196: 67 - 85 .

Brett, M.T., Dörthe, C., Müller-Navarra, T. (1997) The role of highly unsaturated fatty acids in aquatic foodweb processes. Freshwater Biology, 38: 483 - 499.

Bureau, D.P., Harris, A.M., Bevan, D.J., Simmons, L.A., Azevedo, P.A., Cho, C.Y. (2000) Feather meals and meat and bone meals from different origins as protein sources in rainbow trout (Oncorhynchus mykiss) diets. Aquaculture, 181: 281 - 291.

Caballero, M.J., Obach, A., Rosenlund, G., Montero, D., Gisvold, M., Izquierdo, M.S. (2002) Impact of different dietary lipid sources on growth, lipid digestibility, tissue fatty acid composition and histology of rainbow trout, Oncorhynchus mykiss. Aquaculture, 214: $253-271$.

Caballero, M.J., Izquierdo, M.S., Kjorsvik, E., Montero, D., Socorro, J., Fernández, A.J., Rosenlund, G. (2003) Morphological aspects of intestinal cells from gilthead seabream (Sparus aurata) fed diets containing different lípid sources. Aquaculture, 225: 325 - 340.

Caggiano, M., Canese, L., Lupo, A., Cirillo, A. (1993) Experiences of artificial reproduction and larval rearing of sheep head seabream Diplodus puntazzo in the South of Italy. E.A.S. Special Pubblication Ostende. Italy. Vol. 19, 326pp

Cardia, F., Lovatelli, A. (2007) A review of cage aquaculture: Mediterranean Sea. Fisheries and Aquaculture Department, FAO, Rome - Italy. 187 pp.

Cardia, F., Lovatelli, A. (2008) Estudio de la acuicultura en jaulas: en mar Mediterráneo en M. Halwart, D. Soto, J.R. Arthur (Eds). Acuicultura en Jaulas - Estudios regionales y panorama mundial. FAO Documento Técnico de Pesca, № 498. Roma, FAO, 165 - 197 pp.

Carter, C.G., Hauler, R.C. (2000) Fish meal replacement by plant meals in extruded feeds for Atlantic salmon, Salmo salar L. Aquaculture, 185: 299 - 311.

Catacutan, M.R., Pagador, G.E. (2004) Partial replacement of fishmeal by defatted soybean meal in formulated diets for the mangrove red snapper, Lutjanus argentimaculatus (Forsskal 1775). Aquaculture Research, 35: 299 - 306.

Chatzifotis, S., Esteban,A.G., Divanach, P. (2006) Fishmeal replacement by alfalfa protein concentrate in sharpsnout sea bream Diplodus puntazzo. Fisheries Science, 72: 1313 - 1315.

Craig, S.R., Gatlin, D.M. (1995) Coconut oil and beef tallow, but not tricaprylin, can replace menhaden oil in the diet of red drum (Sciaenops ocellatus) without adversely affecting growth or fatty acids composition. The Journal of Nutrition, 3041 - 3048. DOI: 0022-3166/95

Daprà, F., Gai, F., Costanzo, M.T., Maricchiolo, G., Micale, V., Sicuro, B., Caruso, G., Genovese, L., Palmegiano, G.B. (2009) Rice protein-concentrate meal as a potential dietary ingredient in 
practical diets for blackspot seabream Pagellus bogaraveo: a histological and enzymatic investigation. Journal of fish Biology, 74: 773 - 789 .

Davies, S.J., Gouveia, A. (2008) Enhancing the nutritional value of pea seed meals (Pisum sativum) by thermal treatment or specific isogenic selection with comparison to soybean meal for African catfish, Clarias gariepinus. Aquaculture, 283: 116 - 122.

De Francesco, M., Parisi, G., Médale, F., Lupi, P., Kaushik, S.J., Poli, B.M. (2004) Effect of long-term feeding with a plant protein mixture based diet on growth and body/fillet quality traits of large rainbow trout (Oncorhynchus mykiss). Aquaculture, 236: 413 - 429.

De Francesco, M., Parisi, G., Perez-Sanchez, J., Gomez-Requeni, P., Medale, F., Kaushik S.J., Mecatti, M., Poli, B.M. (2007) Effect of high-level fish meal replacement by plant proteins in gilthead sea bream (Sparus aurata) on growth and body/fillet quality traits. Aquaculture Nutrition, 13: 361 372.

Dias, J., Conceicão, L., E.C., Ramalho Ribeiro, A., Borges, P., Valente, L.M.P., Dinis, M.T. (2009) Practical diet with low fish-derived protein is able to sustain growth performancein gilthead seabream (Sparus aurata) during the growth-out phase. Aquaculture, 293: 255 - 262.

Divanach, P., Kentouri, M., Charalambakis, G., Pouget, F., Esterioti, A. (1993) Comparison of growth performance of six Mediterranean fish species reared under intensive farming conditions in Crete (Greece), in raceways with the use of self feeders. En: Production, Environment and Quality. Bordeaux Aquaculture '92. G. Barnabé and P. Kestemont (Eds.) European Aquaculture Society. Special Pubication No 18, Ghent, Belgium, pp. 285 - 297.

Drew, M.D., Ogunkoya, A.E., Janz, D.M., Van Kessel, A.G. (2007) Dietary influence of replacing fish meal and oil with canola protein concentrate and vegetable oils on growth performance, fatty acid composition and organochlorine residues in rainbow trout (Oncorhynchus mykiss). Aquaculture, $267: 260-268$.

Dubois, V., Breton, S., Linder, M., Fanni, J., Parmentier, M. (2007) Fatty acid profiles of 80 vegetable oils with regard to their nutritional potential. European Journal of Lipid Science and Technology, 109: $710-732$.

El-Ebiary, E.S.H. (2005) Rearing sharp-snout seabream (Diplodus puntazzo) fingerlings at varying dietary protein and lipid levels. Egyptian Journal of Aquatic Research, 31: 443 - 452.

Emre, Y., Sevgili, H., Sanh, M. (2008) A preliminary study on the utilization of hazelnut meal as a substitute for fish meal in diets of European sea bass. Aquaculture Research, 39: 324 - 328.

Escaffre, A-M., Kaushik, S., Mambrini, M. (2007) Morphometric evaluation of changes in the digestive tract of rainbow trout (Oncorhynchus mykiss) due to fish meal replacement with soy protein concentrate. Aquaculture, 273: 127 - 138.

Faranda, F., Cavaliere, A., Loparo, G., Manganaro, A., Mazzola, A. (1985) Preliminary studies on reproduction of Puntazzo puntazzo (Gmelin 1789) (Pisces Sparidae) under controlled conditions. Aquaculture, 49: 111 - 123.

Favaloro, E., Lopiano, L., Mazzola, A. (2002) Rearing of sharpsnout seabream (Diplodus puntazzo, Cetti, 1777) in a Mediterranean fish farm: monoculture versus polyculture. Aquaculture Research, 33: $137-140$. 
Favaloro, E., Mazzolo, A. (2003) shape change during the growth of sharpsnout seabream reared under different conditions in a fish farm of the southern Tyrrhenian Sea. Aquaculture Engineering, 29: $57-63$.

FAO (2010) Estado mundial de la pesca y la acuicultura. FAO - ONU para la Agricultura y la alimentación. Roma - Italia, 219 pp. (www.fao.org/docrep/013/il820s/il820s.pdf)

Ferguson, H.W. (1989) Systematic pathology of fish. Iowa State University Press/Ames.

Figueiredo - Silva, A., Rocha, E., Dias, J., Silva, P., Rema, P., Gomes, E., Valente, L.M.P. (2005) Partial replacement of fish oil by soybean oil on lipid distribution and liver histology in European sea bass (Dicentrarchus labrax) and rainbow trout (Oncorhynchus mykiss) juveniles. Aquaculture Nutrition, 11: 147 - 155 .

Fountoulaki, E., Vasilaki, A., Hurtado, R., Grigorakis, K., Karacostas, I, Negas, I., Rigos, G., Kotzamanis, Y., Venou, B., Alexis, M.N. (2009) Fish oil substitution by vegetable oils in commercial diets for gilthead sea bream (Sparus aurata L.); effects on growth performance, flesh quality and fillet fatty acid profile. Recovery of fatty acid profiles by a fish oil finishing diet under fluctuating water temperatures. Aquaculture, 289: 317 - 326.

Francis, D.S., Turchini, G.M., Jones, P.L., De Silva, S.S. (2007) Growth performance, feed efficiency and fatty acid composition of juvenile Murray cod, Maccullochella peelii peelii, fed graded levels of canola and linseed oil. Aquaculture Nutrition, 13: 335 - 350.

Franicevic, V. (1989) Improvements in intensive rearing of Puntazzo puntazzo (Gmelin 1789) (Pisces, Sparidae) larvae. EAS Special Publication, 10.

Fujita, H., Tatsumi, H., Ban, T., Tamura, S. (1986) fine ultrastructural characteristics of the liver of the cod (Gadus morhua macrocephalus), with special regard to the concept of a hepatoskeletal system formed by Ito cells. Cellular Tissue Research, 244: $63-67$.

Furuya, VR.B., Furuya, W.M., Hayshi, C., Soares, C.M. (2000) Niveles de inclusión de harina de girasol en La alimentación de la tilapia del Nilo (Oreochromis niloticus) en etapa juvenil. Zootecnia Tropical, $18(1): 1-10$.

Ganga, R., Montero, D., Bell, J.G., Atalah, E., Ganuza, E., Vega-Orellana, O., Tort, L., Acerete, L., Afonso, J.M., Benitez-Sanatana, T., Fernández Vaquero, A., Izquierdo, M. (2011) Stress response in sea bream (Sparus aurata) held under crowded conditions and fed diets containing linseed and/or soybean oil. Aquaculture, 311: 215 - 223.

Gatland, P. (1995) Growth of Puntazzo puntazzo in cages in Selonda bay, Corinthos, Greece. Cahier de Options Mediterránnées, 16: 51 - 55.

Gatlin, D.M. (2000) Nutrición de Reproductores y Juveniles de Peces Marinos en: Avances en Nutrición Acuícola IV. Memorias del IV Simposium Internacional de Nutrición Acuícola. Civer-Ceredo, R., Pérez-Estrada, C.J., Ricque-Marie, D. y Cruz-Suárez, L.E. (Eds). Noviembre 15 - 18 1998. La Paz. B.C.S. - México.

Gatlin, D.M., Barrows, F.T., Brown, P., Dabrowski, K., Gibson Gaylord, T., Hardy, R.W., Herman, E., Hu, G., Krogdahl, A., Nelson, R., Overturf, K., Rust, M., Sealey, W., Skonberg, D., Souza, E.J., Stone, D., Wilson, R., Wurtele, E. (2007) Expanding the utilization of sustainable plant products in aquafeeds: a review. Aquaculture Research, 38: 551 - 579. 
Gatlin, D.M. (2010) Principles of Fish Nutrition. Sothern Regional Aquaculture Center (SRAC) Publication. Department of Wildlife and Fisheries Sciences, United States Department of Agriculture. National Institute of Food and Agriculture. Texas - U.S.A. $1-7$.

García-García, B., Rueda, F.M., Hernández, M.D., Aguado, F., Egea, M.A., Faraco, F. (2001) Crecimiento e índice de conversión del sargo picudo (Puntazzo puntazzo, Gmelin, 1789) en engorde intensivo en tanques. En: Convergencia entre Investigación y Empresa: Un reto para el siglo XXI. FernándezPalacios, H. y Izquierdo, M. (Eds) Monografías del ICCM № 4. Las Palmas de Gran Canaria. Pp: $385-390$.

García-García, B., Hernández, M.D., García-García, J., Martínez, F.J., Jover, M. (2003) Desarrollo de modelos de crecimientos y tasas de alimentación en función del peso, la temperatura y el contenido de harina de soja en la dieta del sargo picudo (Diplodus puntazzo). IX Congreso Nacional de Acuicultura. Cádiz - España.

García-García, B., Hernández, M.D., Cárdenas, S., Muñoz, J.L., Rodríguez, C., Carrasco, J.F., Pastor, E., Gráu, A., Gines, R., Hernández-Cruz, C.M., Estévez, A., Bellot, O., Rodríguez, L.M., OteroLlovo, J., Martínez, S., Tomás, A. (2008) Análisis sensorial de cinco especies de espáridos (besugo, dentón, hurta, pargo y sargo picudo) en ocho localidades costeras de España. Ministerio de Medio Ambiente, Medio Rural y Marino y JACUMAR, Madrid - España 64 pp.

García-García, J., García-García, B. (2010) Econometric model of viability/profitability of on growing sharpsnout sea bream (Diplodus puntazzo) in sea cages. Aquaculture International, 18: 955 - 971.

Gill, N., Higgs, D.a., Skura, B.J., Rowshandeli, M., Dosanjh, B.S., Mann, J., Gannam, A.L. (2006) Nutritive value of partially dehulled and extruded sunflower meal for post-smolt Atlantic salmon (Salmo salar L.) in sea water. Aquaculture Research, 37: 1348 - 1359.

Glencross, B., Hawkins, W., Curnow, J. (2003) Evaluation of canola oils as alternative lipid resources in diets for juvenile red seabream, Pagrus auratus. Aquaculture Nutrition, 9: 305 - 315.

Glencross, B., Evans, D., Hawkins, W., Jones, B. (2004) Evaluation of dietary inclusion of yellow lupin (Lupinus luteus) kernel meal on the growth, feed utilisation and tissue histology of rainbow trout (Oncorhynchus mykiss). Aquaculture, 235: $411-422$.

Glencross, B.D. (2009) Exploring the nutritional demand for essential fatty acids by aquaculture species. Reviews in Aquaculture, 1: 7 - 124.

Gomez-Requeni, P., Mingarro, M., Calduch-Giner, J.A., Medale, F., Martin, S.A.M., Houlihan, D.F., Kaushik, S., Perez-Sanchez, J. (2004) Protein growth performance, amino acid utilisation and somatotropic axis responsiveness to fish meal replacement by plant protein sources in gilthead sea bream (Sparus aurata). Aquaculture, 232: 493 - 510.

Greco, S., Lo Paro, G., Caridi, D., Perdichizzi, F., Cammaroto, S., Micale, V., Genovese, L. (1993) Controlled spawning and larval development in the sharpsnout seabream (Diplodus puntazzo) Sparidae, E.A.S. Special Publication, № 18, pp. 185 - 188.

Grigorakis, K. (2007) Compositional and organoleptic quality of farmed and wild gilthead sea bream (Sparus aurata) and sea bass (Dicentrarchus labrax) and factors affecting it: A review. Aquaculture, 272: $55-75$. 
Grisdale-Helland, B., Ruyter, B., Rosenlund, G., Obach, A., Helland, S.J., Sandberg, M.G., Standal, H., Røsjø, C. (2002) Influence of high contents of dietary soybean oil on growth, feed utilization, tissue fatty acid composition, heart histology and standard oxygen consumption of Atlantic salmon (Salmo salar) raised at two temperatures. Aquaculture, 207: 311 - 329.

Halver, J.E. (2002) The Vitamins. In: Fish Nutrition. (Eds: J.E. Halver y R.W. Hardy) 3er Edition. Academic Press. Elservier Science Imprint. Amsterdam - Boston - London - New York - Oxford - Paris - San Diego - San Francisco - Singapore - Sydney - Tokyo. 810pp.

Hansen, J.Ø., Penn, M., Øverland, M., Shearer, D., Krogdahl, Å., Mydland, L.T., Storebakken, T. (2010) High inclusion of partially deshelled and whole krill meals in diets for Atlantic salmon (Salmo salar). Aquaculture, 310: 164 - 172.

Heck, N.E., Calber, H.E. (1977) Use of animal fat in formulated diets for yellow perch (Perca flavescens). World Mariculture Society, 8: 787 - 794.

Hibiya T. (Editor): An Atlas of Fish Histology. Normal and Pathological Features.-147 pp. Stuttgart/New York: Gustav Fischer Verlag 1982 (for Japan: Tokyo: Kodansha Ltd.). ISBN 3437-30388-0 (Stuttgart), 0-89574-174-1 (New York), 4-06-13974-1 (Japan).

Hernández, M.D., Martínez, F.J., García-García, B. (2001) Sensory evaluation of framed sharpsnout seabream (Diplodus puntazzo). Aquaculture International, 9: 519 - 529.

Hernández, M.D., Martínez, F.J., Jover, M., García-García, B. (2007) Effects of partial replacement of fish meal by soybean meal in sharpsnout seabream (Diplodus puntazzo) diet. Aquaculture, 263: 159 167.

Higgs, J.D. (2000) The changing nature of red meat: 20 years of improving nutritional quality. Trends in Food Science and Technology, 11: 85 - 95.

Izquierdo, M.S., Obach, A., Arantzamendi, L., Montero, D., Robaina, L., Rosenlund, G. (2003) Dietary lípido sources for seabream and seabass: growth performance, tissue composition and flesh quality. Aquaculture Nutrition, 9: 397 - 407.

Izquierdo, M.S., Montero, D., Robaina, L., Caballero, M.J., Rosenlund, G., Ginés, R. (2005) Alternations in fillet fatty acid profile and flesh quality in gilthead seabream (Sparus aurata) fed vegetable oils for a long term period. Recovery of fatty acid profiles by fish oil feeding. Aquaculture, 250: 431 444.

Karakatsouli, N., Papafotiou, P., Papoutsoglou, E. (2006) Mono - and duoculture of juvenile sharpsnout seabream Diplodus puntazzo (Cetti) and gilthead seabream Sparus aurata L. in a recirculated water system. Aquaculture Research, $1-8$.

Kentouri, M., Divanach, P., Charlambakis, G., Pouget, F., Sterioti, A. (1992) Comparison of growth performance of six Mediterranean fish species, reared under intensive framing conditions in Crete (Greece), in raceways with the use of self feeders. Résumés du Colloque Scientifique Sur la Pisciculture Intensive et Environnement Bordeaux. Aquaculture, 14.

Kinkelin, P., Michel C., Ghittino, P. (1991) Caracteres propios de las enfermedades de los peces. En: Tratado de las enfermedades de los peces. Ed. ACRIBIA, S.A., Zaragoza - España 353 pp. (Cap. II pág. 21). 
Kissil, G.W., Lupatsch, I, Higgs, D.A., Hardy, R.W. (2000) Dietary substitution of soy and rapeseed protein concentrates for fish meal, and their effects on growth and nutrient utilization in gilthead seabream Sparus aurata L. Aquaculture Research, 31: 595 - 601.

Kousoulaki, K., Albrektsen, S., Langmyhr, E., Olsen H.J., Campbell, P., Aksnes, A. (2009) The water soluble fraction in fish meal stickwater) stimulates growth in Atlantic salmon (Salmo salar L.) given high plant protein diets. Aquaculture, 289: $74-83$.

Kowalska, a., Zakés, Z., Jankowska, B., Siwicki, A. (2009) Substituting vegetable oil for fish oil in pikeperch diets: the impact on growth, internal organ histology, blood biochemical parameters, and proximate composition. Aquaculture Nutrition, 17: 148 - 163.

Lee, K., Powell, M., Barrows, F., Smiley, S., Bechtel, P., Hardy, R. (2010) Evaluation of supplemental fish bone meal made from Alaska seafood processing by product and dicalcium phosphate in plant protein based diets for rainbow trout (Oncorhynchus mykiss). Aquaculture, 302: 248 - 255.

Li, M.H., Robinson, E.H., Tucker, C.S., Manning, B.B., Khoo, L. (2009) Effects of dried algae Schizochytrium sp., a rich source of docosahexaenoic acid, on growth, fatty acid composition, and sensory quality of channel catfish Ictalurus punctatus. Aquaculture, 292: 232 - 236.

Lie, Ø. (2001) Flesh quality - the role of nutrition. Aquaculture Research, 32: 341 - 348.

Lim, S-J. \& Lee, K-J. (2009) Partial replacement of fish meal by cottonseed meal and soybean meal with iron and phytase supplementation for parrot fish Oplegnathus fasciatus. Aquaculture, 290: 283 289.

Liu, K.K.M., Barrows, T., Hardy, R.W., Dong, F.M. (2004) Body composition, growth performance, and product quality of rainbow trout (Oncorhynchus mykiss) fed diets containing poultry fat, soybean/corn lecithin, or menhaden oil. Aquaculture, 238: 309 - 328.

Maina, J.G., Beames, R.M., Higos, D., Mbugua, P.N., Iwama, G., Lisia, S.M. (2003) Partial replacement of fishmeal with sunflower cake and corn oil in diets for tilapia (Oreochromis niloticus) effect on whole body fatty acids. Aquaculture Research, 34: 601 - 608.

Marcoulli, P.A., Alexis, M.N., Andriopoulou, A., Iliopoulou-Georgudaki J. (2004) Development of a reference diet for use in indispensable amino acid requirement studies of gilthead seas bream Sparus aurata L. Aquaculture Nutrition, 10: 335 - 343.

Marengos, C. (1995) Larviculture of the sheepshead seabream Puntazzo puntazzo (Gmelin 1789) Pisces, Sparidae, C.I.H.E.A.M., Zaragoza, Spain $41-46$ pp.

Martinez, C.A. (1984) Advances in the substitution of fish meal and soybean meal by sunflower meal in diets of Rainbow trout (Salmo gairdneri L.). Anales del Instituto de Ciencias del Mar y Limnología.

Martínez-Llorens, S., Tomás-Vidal, A., Moñino, V.A., Pla Torres, M., Jover Cerdá, M. (2007) Effects of dietary soybean oil concentration on growth, nutrient utilization and muscle fatty acid composition of gilthead sea bream (Sparus aurata L.) Aquaculture Research, 38: 76 - 81.

Martínez-Llorens, S., Tomás, A., Moñino, A., Gómez, J., Pla, M., Jover, M. (2008) Blood and haemoglobin meal as protein sources in diets for gilthead sea bream (Sparus aurata) Effects on growth, nutritive efficiency and fillet sensory differences. Aquaculture Research, 39: 1028 - 1037. 
Martínez-Llorens, S., Tomás Vidal, A., Jauralde García I., Pla, Torres, M., Jover Cerdá, M. (2009) Optimum dietary soybean meal level for maximizing growth and nutrient utilization of ongrowing gilthead seabream (Sparus aurata). Aquaculture Nutrition, 15: 320 - 328.

Martino, R.C., Cyrino, J.E.P., Portz L., Trugo, L.C. (2002) Performance and fatty acid composition of surubim (Pseudoplatystoma coruscans) fed diets with animal and plant lipids. Aquaculture, 209: $233-246$.

Martins, D.A., Valente, L.M.P., Lall, S.P. (2009) Apparent digestibility of lipid and fatty acids in fish oil, poultry fat and vegetable oil diets by Atlantic halibut, Hippoglossus hippoglossus L. Aquaculture, 294: $132-137$.

Mena Sellés, C., García-García, B. (2002) Importancia de la proteína vegetal en la dieta natural de poblaciones salvajes de sargo picudo Diplodus puntazzo (Cetti, 1777); Sus implicaciones en el cultivo intensivo. Revista AquaTIC № 17. www.revistaaquatic.com/swusyiv/hyml/styl705/sargo.htm.

Micale, V., Perdichizzi, F., Basciana, G. (1996) Aspects of the reproductive biology of the sharpsnout seabream Diplodus puntazzo (Cetti, 1777). Gametogenesis and gonadal cycle in captivity during the third year of life. Aquaculture, 140: 281 - 291.

Montero, D., Kalinowski, T., Obach, A., Robaina, L., Tort, L., Caballero, M.J., Izquierdo, M.S. (2003) Vegetable lipid sources for gilthead seabream (Sparus aurata): effects on fish health. Aquaculture, 225: $353-370$.

Montero, D., Grasso, V., Izquierdo, M.S., Ganga, R., Real, F., Tort, L., Caballero, M.J., Acosta, F. (2008) Total substitution of fish oil by vegetable oils in gilthead sea bream (Sparus aurata) diets: Effects on hepatic Mx expresión and some immune parameters. Fish \& Shellfish Immunology, 24: 147 155.

Mørkøre, T., Netteberg, C., Johnsson, L., Pickova, J. (2007) Impact of dietary oil source on product quality of farmed Atlantic cod, Gadus morhua. Aquaculture, 267: 236 - 247.

Mourete, G., Dick, J.R., Bell, J.G., Tocher, D.R. (2005) Effect of partial substitution of dietary fish oil by vegetable oils on desaturation and B-oxidation of $\left[1^{-14} \mathrm{C}\right] 18: 3 n-3$ (LNA) and $\left[1^{-14} \mathrm{C}\right] 20: 5 n^{-}$ 3(EPA) in hepatocytes and enterocytes of European sea bass (Dicentrarchus labrax L.). Aquaculture, 248: 173 - 186.

Mugrditchian, D.s., Hardy, R.W., Iwaoka, W.T. (1981) Linseed oil and animal fat as alternative lipid sources in dry diets for Chinook salmon (Oncorhynchus tshawytscha). Aquaculture, 25: 161 - 172.

Nengas, I., Alexis, M.N., Davies, S.J. (1999) High inclusion levels of poultry meals and related by products in diets for gilthead seabream Sparus aurata L. Aquaculture, 179: 13 - 23.

Ng, W-K., Tee, M-C., Boey, P-L. (2000) Evaluation of crude palm oil and refined palm olein as dietary lipids in pelleted feeds for a tropical bagrid catfish Mystus nemurus (Cuvier \& Valenciennes). Aquaculture Research, 31: 337 - 347.

Ng, W-K., Wang, Y. (2011) Inclusion of crude palm oil in the broodstock diets of female Nile tilapia, Oreochromis niloticus, resulted in enhanced reproductive performance compared to brood fish fed diets with added fish oil or linseed oil. Aquaculture, 314: 122 - 131. 
Noffs, M.D., Martino, R.C., Trugo, L.C., Urbinati, E.C., Fernandes, J.B.K., Takahashi, L.S. (2009) Dietary fish oil replacement with lard and soybean oil affects triacylglycerol and phospholipid muscle and liver docosahexaenoic acid content but not in the brain and eyes of surubim juveniles Pseudoplatystoma sp. Fish Physiology and Biochemistry, 35: 399 - 412.

Ogunkoya, E., Page, G., Adewolu, M., Bureau, D. (2006) Dietary incorporation of soybean meal and exogenous enzyme cocktail can affect physical characteristics of faecal material egested by rainbow trout (Oncorhynchus mykiss) Aquaculture, 254: 466 - 475.

Oliva-Teles, A., Gonçalves, P. (2001) Partial replacement of fishmeal by brewers yeast (Saccaromyces cerevisae) in diets for sea bass (Dicentrarchus labrax) juveniles. Aquaculture, 202: 269 - 278.

Olsen, R.E., Dragnes, B.T., Myklebust, R., Ringo, E. (2003) Effect of soybean oil and soybean lecithin on intestinal lipid composition and lipid droplet accumulation of rainbow trout, Oncorhynchus mykiss Walbaum. Fish Physiology and Biochemistry, 29: 181 - 192.

Olsen, R.E., Hansen, A-C., Rosenlund, G., Hemre,G-I., Mayhew, T.M., Knudsen, D.L., Eroldogan, O.T., Myklebust, R., Karlsen, O. (2007) Total replacement of fish meal with plant proteins in diets for Atlantic cod (Gadus morhua L.) II - Health aspects. Aquaculture, 272: 612 - 624.

Olsvik, P.A., Torstensen, B.E., Berntssen, M.H.G. (2007) Effect of complete replacement of fish oil with plant oil on gastrointestinal cell death, proliferation and transcription of eight genes' encoding proteins responding to cellular stress in Atlantic salmon Salmo salar L. Journal of Fish Biology, 71: $550-568$.

Olvera-Novoa, M.A., Olivera-Castillo, L., Martínez-Palacios, C.A. (2002) Sunflower seed meal as a protein sources in diets for Tilapia rendalli (Boulanger, 1896) fingerlings. Aquaculture Research, 33: $223-229$.

Overland, M., Sørensen, M., Storebakken, T., Penn, M., Krogdahl, Å., Skrede, A. (2009) Pea protein concentrate substituting fish meal or soybean meal in diets for Atlantic salmon (Salmo salar) Effect on growth performance, nutrient digestibility, carcass composition, gut health, and physical feed quality. Aquaculture, 288: $305-311$.

Ozorio, R.O.A., Turini, B.G.S., Môro, G.V., Oliverira, L.S.T., Portz, L., Cyrino, J.E.P. (2010) Growth, nitrogen gain and indispensable amino acid retention of pacú (Piaractus mesopotamicus, Holmberg 1887) fed different brewers yeast (Sccharomyces cerevisiae) levels. Aquaculture Nutrition, 16: 276 283.

Palmegiano, G.B., Daprà, F., Fomeris, G., Gai, F., Gasco, L., Guo, K., Peiretti, P.G., Sicuro, B., Zoccarato, I. (2006) Rice protein concentrate meal as a potential ingredient in practical diets for rainbow trout (Oncorhynchus mykiss). Aquaculture, 258: 357 - 367.

Palmegiano, G.B., Costanzo, M.T., Daprà, F., Gai, F., Galletta, M.G., Maricchiolo, g., Micale, V., Peiretti, P.G., Genovese, L. (2007) Rice protein concentrate meal as potencial dietary ingredient in practical diets for blackspot sebream (Pagellus bogaraveo). Journal of Animal Physiology and Animal Nutrition, 91: 235 - 239.

Papadaki, M., Papadopoulou, M., Siggelaki, I., Mylonas, C. (2008) Egg and sperm production and quality of sharpsnout sea bream (Diplodus puntazzo) in captivity. Aquaculture, 276: 187 - 197. 
Pastor, E., Grau, A., Riera, F., Pou, S., Massuti, E., Grau, A.M. (2000) Experiences in the culture of new species in the "Estación de Acuicultura" of the Balearic government (1980 - 1998). Options Méditerranéennes Serie B. Etudes et recherches, 47: 371 - 379.

Pastor, J., Hernández, M.D., Jover, M., Martínez, F.J., García-García, B. (2001) Efecto de La sustitución parcial de harina de pescado por harina de soja en la dita para sargo picudo (Diplodus puntazzo, Cetti 1777) sobre su crecimiento, composición corporal y palatabilidad. In: VIII Congreso Nacional de Acuicultura, Acuicultura y desarrollo sostenible., Santander (Cantabria), pp. 125 127.

Peng, S., Chen, L., Qin, J.G., Hou, J., Yu, N., Long, Z., Ye, J., Sun, X. (2008) Effect of replacemente of dietary fish oil by soybean oil on growth performance and liver biochemical composition in juvenile black seabream, Acanthopagurs schlegeli. Aquaculture, 276: 154 - 161.

Penn M.H., Bendiksen, E.A., Campbell P., Krogdahl, A. (2011) Pea protein concentrate induces enteropaty in Atlantic salmon (Salmo salar L.). Aquaculture, 310: 267 - 273.

Pereira, T.G., Oliva-Teles, A. (2002) Preliminary evaluation of pea seed meal in diets for gilthead sea bream (Spuarus aurata) juveniles. Aquaculture Research, 33: 1183 - 1189.

Pereira, T.G., Oliva-Teles, A. (2003) Evaluation of corn gluten meal as a protein source in diets for gilthead sea bream (Sparus aurata L.) juveniles. Aquaculture Research, 34: 1111 - 1117.

Pereira, T.G., Oliva-Teles, A. (2004) Evaluation of micronized lupin seed meal as an alternative protein source in diets for gilthead sea bream Sparus aurata L., juveniles. Aquaculture Research, 35: 828 835.

Piedecausa, M.A., Mazón, M.J., García-Garcia, B., Hernández, M.D. (2007) Effects of total replacement of fish oil by vegetable oils in the diets of sharpsnout sea bream (Diplodus puntazzo). Aquaculture, 263: $211-219$.

Pratoomyot, J., Bendiksen, E.A., Bell, J.G., Tocher, D.R. (2008) comparison of effects of vegetable oils blended with southern hemisphere fish oil and decontaminated northern hemisphere fish oil on growth performance, composition and gene expression in Atlantic salmon (Salmo salar L.). Aquaculture, 280: 170 - 178

Pratoomyot, J., Bendiksen, E.A., Bell, J.G., Tocher, D.R. (2010) Effect of increasing replacement of dietary fishmeal with plant protein sources on growth performance and body lipid composition of Atlantic salmon (Salmo salar L.) Aquaculture, 305: 124 - 132.

Regan, M.D., Kuchel, L.J., Huang, S.S.Y., Higgs, D.A., Wang, J., Schulte, P.M., Brauner, C.J. (2010) The effect of dietary fish oil and poultry fat replacement with canola oil on swimming performance and metabolic response to hypoxia in stream type spring Chinook salmon parr. Aquaculture, 308: $183-189$

Refstie, S., Tiekstra, H.A.J. (2003) Potato protein concentrate with low content of solanidine glycoalkaloids in diets for Atlantic salmon (Salmo salar). Aquaculture, 216: $283-298$.

Refstie, S., Baeverfjord, G., Seim, R.R., Elvebø, O. (2010) Effect of dietary yeast cell wall ß-glucans and MOS on performance, gut health, and salmon lice resistance in Atlantic salmon (Salmo salar) fed sunflower and soybean meal. Aquaculture, 305: 109 - 116. 
Richard, N., Morente, G., Kaushik, S., Corraze, G. (2006) Replacement of a large portion of fish oil by vegetable oils does not affect lipogenesis, lipid transport and tissue lipid uptake in European seabass (Dicentrarchus labrax L.) Aquaculture, 261: 1077 - 1087.

Robaina, L., Moyano, F.J., Izquierdo, J.M., Socorro, J., Vergara, J.M., Moreno, D. (1997) Corn gluten and meat and bone meals as proteína sources in diets for gilthead seabream (Sparus aurata): Nutritional and histological implications. Aquaculture, 157: 347 - 359.

Robert, R.J. (1981) Patología de los Peces. Ed. Mundi Prensa. Madrid - España. 366 pp.

Robertson, C., Braadley, T. (1992) Liver ultrastructure of juvenile Atlantic salmon (Salmo salar). Journal of Morphology, 211: $41-54$.

Rodriguez, A., Gisbert, E., Rodríguez, G., Castelló-Orvay, F. (2005) Histopathological observations in European glass eels (Anguilla anguilla) reared under different diets and salinities. Aquaculture, 244: $203-214$.

Romarheim, O.H., Skrede, A., Gao, Y., Krogdahl, A., Denstadli, V., Lilleeng, E., Storebakken, T. (2006) Comparison of white flakes and toasted soybean meal partly replacing fish meal as protein source in extruded feed for rainbow trout (Oncorhynchus mykiss). Aquaculture, 256: 354 - 364.

Romarheim, O.H., Skrede, A., Penn, M., Mydland, L., Krogdahl, A., Storebakken, T. (2008) Lipid digestibility, bile drainage and development of morphological intestinal changes in rainbow trout (Oncorhynchus mykiss) fed diets containing defatted soybean meal. Aquaculture, 274: 329 338.

Ross, M.H., Reith, E.J., Rombell, L.J. (1989) Histology: A text and atlas. $2^{\text {nd }}$ edition. Williams \& Wilkins. Baltimore, Philadelphia, Hong Kong, London, Munich, Sydney, Tokyo.

Russell, P.M., Davies, S.J., Gouveia, A., Tekinay, A.A. (2001) Influence of dietary starch source on liver morphology in juvenile cultured European sea bass (Dicentrarchus labrax L). Aquaculture Research, 32: 306 - 314.

Ruyter, B., Moya-Falcón, C., Rosenlund, G., Vegusdal, A. (2006) Fat content and morphology of liver and intestine of Atlantic salmon (Salmo salar): Effects of temperature and dietary soybean oil. Aquaculture, 252: $441-452$.

Sá, R., Pousao-Ferreira, P., Oliva-Teles, A. (2006) Effect of dietary protein and lipid levels on growth and feed utilization of White sea bream (Diplodus sargus) juveniles. Aquaculture Nutrition, 12: 310 321.

Sakano, E., Fujita, H. (1982) Comparative aspects on the fine structure of the teleost liver. Okajima Folia Anatomy Japanese, 58: 501 - 520.

Sala, E., Ballesteros, E. (1997) Partioning of space and food resources by three fish of the genus Diplodus (Sparidae) in a Mediterranean rocky infralitoral ecosystem. Marine Ecology Progress Series, 152: $273-283$.

Salze, G., McLean, E., Battle, P.R., Schwarz, M.H., Craig, S.R. (2010) Use of soy protein concentrate and novel ingredients in the total elimination of fish meal and fish oil in diets for juvenile cobia, Rachycentron canadum. Aquaculture, 298: 294 - 299. 
Sánchez-Lozano, N.B. Tomás Vidal, A., Martínez-Llorens, S., Nogales Mérida, S., Espert Blanco, J., Moñino López, A., Pla Torres, M., Jover Cerdá, M. (2007) Growth and economic profit of gilthead sea bream (Sparus aurata, L.) fed sunflower meal. Aquaculture, 272: 578 - 534.

Sánchez-Lozano, N.B., Martínez-Llorens, S., Tomás-Vidal, A., Jover Cerdá, M. (2009) Effect of highlevel fish meal replacement by pea and rice concentrated protein on growth, nutrient utilization and fillet quality in gilthead seabream (Sparus aurata, L.) Aquaculture, 298: 83 - 89.

Sánchez-Lozano, N.B., Martínez-Llorens , S., Tomás-Vidal, A., Jover Cerdá, M. (2011) Amino acid retention of gilthead sea bream (Sparus aurata, L.) fed with pea protein concentrate. Aquaculture Nutrition, 17: $604-614$.

Savona, B., Tramati, C., Mazzola, A. (2011) Digestive Enzimes in Larvae and Juveniles of Farmed Sharpsnout Seabream (Diplodus puntazzo) Cetti, 1777). The Open Marine Biology Journal, 5: 47 57.

Sealey, W.M., Barrows, F.T., Smith, C.E., Overturf, K., LaPatra, S.E. (2009) Soybean meal level and probiotics in first feeding fry diets alter the ability of rainbow trout Oncorhynchus mykiss to utilize high levels of soybean meal during grow-out. Aquaculture, 293: 195 - 203.

Sitjà-Bobadilla, A., Peña-Llopis, S., Gómez-Requeni, P., Médale, F., Kaushik, S., Pérez-Sánchez, J. (2005) Effect of fish meal replacement by plant protein sources on non-specific defense mechanisms and oxidative stress in gilthead sea bream (Sparus aurata). Aquaculture, 249: 387 - 400.

Schulz, C., Wickert, M., Kijora, C., Ogunji, J., Rennert, B. (2007) Evaluation of pea protein isolated as alternative protein source in diets for juvenile tilapia (Oreochromis niloticus). Aquaculture Research, 38: $537-545$.

Soler-Vila, A., Coughlan, S., Guiry, M.D., Kraan, S. (2009) The red alga Porphyra dioica as a fish-feed ingredient for rainbow trout (Oncorhynchus mykiss): effects on growth, feed efficiency, and carcass composition. Journal of Applied Phycology, 21: 617 - 624

Stone, D.A.J., Gaylord, G.T., Johanse, K.., Overturf, K., Sealey, W.M., Hardy, R.W. (2008) Evaluation of the effects of repeated fecal collection by manual stripping on the plasma cortisol levels, TNF- $\alpha$ gene expression, and digestibility and availability of nutrients form hydrolyzed poultry and egg meal by rainbow trout, Oncorhynchus mykiss (Walbaum). Aquaculture, 275: 250 - 259.

Storebakken, T., Baeverfjord, G., Skrede, A., Olli, J.J., Berge, G.M. (2004) Bacterial protein grown on natural gas in diets for Atlantic salmon, Salmo salar, in freshwater. Aquaculture, 241: 413 - 425.

Subhadra, B., Lochmann, R., Rawles, S., Chen, R. (2006) Effect of fish-meal replacement with poultry byproduct meal $\mathrm{n}$ the growth, tissue composition and hematological parameters of largemouth bass (Micropterus salmoides) fed diets containing different lipids. Aquaculture, 260: 221 - 231.

Suontama, J., Karlsen, O., Moren, M., Hemre, G., Melle, W., Langmyhr, E., Mundheim, H., Ringoe, E., Olsen, R.E. (2007) Growth, feed conversion and chemical composition of Atlantic salmon (Salmo salar L.) and Atlantic halibut (Hippoglosus hippoglossus L.) fed diets supplemented with krill or amphipods. Aquaculture Nutrition, 13: 241 - 255.

Suzuki, N., Yamamoto, T. (2004) Histological observation of intestinal degeneration of defatted soybean meal diet and supplemental effect of soybean lecithin for fingerling rainbow trout, Oncorhynchus 
mykiss. (En japones, pero con resumen en inglés) Journal of the School of Marine Science and Technology, 2: 25-36.

Takagi, S., Murata, H., Goto, T., Endo, M., Yamashita, H., Ukawa, M. (2008) Taurine is an essential nutrient for yellowtail Seriola quinqueradiata fed non-fish diets based on soy protein concentrate. Aquaculture, 280: 198 - 205.

Tan, Q., Xie, S., Zhu, X., Lei, W., Yang, Y. (2007) Effect of dietary carbohydrate - to - lipid ratios on growth and feed utilization in Chinese longsnout catfish (Leiocassis longirostris Günther). Journal Apply of Ichthyology, 23: $605-610$.

Tanamati, A., Stevanato, F.B., Laguila Visentainer, J.E., Matsushita, M., Evelázio de Souza, N., Visentainer, J.V. (2009) Fatty acid composition in wild and cultivated pacu and pintado fish. European Journal of Lipid Science and Technology, 11l: 183 - 187.

Torrejón Atienza, M., Chatzifotis, S., Divanach, P. (2004) Macronutrient selection by sharp scout seabream (Diplodus puntazzo). Aquaculture, 232: 481 - 491.

Teoh, C-Y., Turchini, G.M., Ng, W-K. (2011) Genetically improved farmed Nile tilapia and red hybrid tilapia showed differences in fatty acid metabolism when fed diets with added fish oil or a vegetable oil blend. Aquaculture, 312: 126 - 136.

Tibaldi, E., Kaushik, S.J. (2003) Aminoacids requirements of Mediterranean fish species. Cahiers Options Mediterranéennes. Vol. 63.

Tomás, A., De la Gándara, F., García-Gómez, A., Perez, L., Jover, M. (2005) Utilization of soybean meal as an alternative protein source in the Mediterranean yellowtail, Seriola dumerili. Aquaculture Nutrition, 11: $333-340$.

Torstensen, B.E., Espe, M., Sanden, M., Stubhaug, I., Waagbø, R., Hemrer, G., Fontanillas, R., Nordgarden, U., Hevrøy, E.M., Olsvik, P., Berntssen, M.H.G. (2008) Novel production of Atlantic salmon (Salmo salar) protein based on combined replacement of fish meal and fish oil with plant meal and vegetable oil blends. Aquaculture, 285: 193 - 200.

Tramati, C., Savona, B., Mazzola, A. (2005) A study of the pattern of digestive enzymes in Diplodus puntazzo (Cetti, 1777) (Osteichthyes, Sparidae) evidence for the definition of nutritional protocols. Aquaculture International, 13: 89 - 95.

Turchini, G.M., Mentasit, T., Froyland, L., Orban, E., Caprino, F., Moretti, V.M., Valfré, F. (2003) effects of alternative dietary lipid sources on performance, tissue chemical composition, mitochondrial fatty acid oxidation capabilities and sensory characteristics in brown trout (Salmo trutta L.) Aquaculture, 225: $251-267$.

Turchini, G.M., Torstensen, B.E., Ng, W-K. (2009) Fish oil replacement in finfish nutrition. Reviews in Aquaculture, 1: 10 - 57 .

Turchini, G.M., Francis, D.S., Keast, R.S.J., Sinclair, A.J. (2011) Transforming salmonid aquaculture from a consumer to a producer of long chain omega-3 fatty acids. Food Chemistry, 124: 609- 614.

Wake, K., Motomatsu, K., Senoo, H. (1987) Stellate cell storing retinol in the liver of adult lamprey, Lampetra japonica, Cellular tissue Research, 249: 289 - 299.

Wang, X-X., Li, Y-J., Hou, C-L., Gao, Y., Wang, Y-Z. (2011) Influence of different dietary lipid sources on the growth, tissue fatty acid composition, histological changes and peroxisome proliferator- 
activated receptor $y$ gene expression in large yellow croaker (Pseudosciaena crocea R.). Aquaculture Research, 1 - 11 .

Wassef, E.A., Wahby, O.M., Sakr, E.M. (2007) Effect of dietary vegetable oils on health and liver histology of gilthead seabream (Sparus aurata) growers. Aquaculture Research, 38: 852 - 861.

Wilson, R.P. (2002) Amino Acids and Proteins. (Eds: J.E. Halver y R.W. Hardy) 3er Edition. Academic Press. Elservier Science Imprint. Amsterdam - Boston - London - New York - Oxford - Paris San Diego - San Francisco - Singapore - Sydney - Tokyo. 810pp

Yoshitomi, B., Aoki, M., Oshima, S., Hata, K. (2006) Evalution of krill (Euphausia superba) meal as a partial replacement for fish meal in rainbow trout (Oncorhynchus mykiss) diets. Aquaculture, 261: $440-446$

Yoshitomi, B., Aoki, M., Oshima, S-I. (2007) Effect of total replacement of dietary fish meal by low fluoride krill (Euphausia superba) meal on growth performance of rainbow trout (Oncorhynchus mykiss) in fresh water. Aquaculture, 266: $219-225$.

Xue, M., Luo, L., Wu, X., Ren, Z., Gao, P., Yu, Y., Pearl, G. (2006) Effects of six alternative lipid sources on growth and tissue fatty acid composition in Japanese sea bass (Lateolabrax japonicus). Aquaculture, 260: 206 - 214.

Zhou, Q-C., Li, C-C., Liu, C-W., Chi, S-Y., Yang, Q-H. (2007) Effects of dietary lipid sources on growth and fatty acid composition of juvenile shrimp, Litopenaeus vannamei. Aquaculture Nutrition, 13: $222-229$.

Zhou, Q-B., Wu, H-D., Zhu, C-S., Yan, X-H. (2010) Effect of dietary lipids on tissue fatty acids profile, growth and reproductive performance of female rice field eel (Monopterus albus). Fish Physiology and Biochemistry. DOI: 10.1007/s10695-010-9444-1.

\section{BIBLIOGRAFÍA DE INTERNET}

http://www.mapa.es/es/pesca/pags/rmarinas mapa/cabopalos/galeria fotos/galeria fotos.htm (Imagen del sargo picudo)

FEDNA http://wwwl.etsia.upm.es/fedna/grasasyaceites/manteca.htm (Datos de la composición del aceite de soja y manteca de cerdo)

Fishbase http://www.fishbase.org/summary/SpeciesSummary.php?id=1749 (Datos tomados de algunas especies marinas) 

CAPITULO 2.

\section{JUSTIFICACIÓN Y OBJETIVOS}





\section{CAPÍTULO 2. JUSTIFICACIÓN Y OBJETIVOS}

El sargo picudo (Diplodus puntazzo) es una de las especies alternativas propuestas por el Ministerio de Medio Ambiente y Medio Rural y Marino, el Instituto Murciano de Investigación y Desarrollo Agrario y Alimentario y la Junta Nacional Asesora de Cultivos Marinos (JACUMAR) a la dorada y la lubina, por ser una especie endémica del Mediterráneo, de fácil reproducción y cuyo ciclo productivo puede solaparse sin problema con la producción de la dorada. Además, por ser una especie omnívora, que puede cohabitar con la dorada u otros espáridos sin que esto afecte a su crecimiento y sin interferir con el crecimiento de las otra especie (Karakatsouli et al., 2006). Actualmente el sargo picudo se produce y comercializa en Grecia, Italia, Turquía y Chipre con precios muy competitivos. Por ello, esta especie puede ser una excelente alternativa para los piscicultores españoles.

No obstante, en los últimos años en los que se ha empezado a producir el sargo, no se ha diseñado y comercializado un pienso específico para esta especie, ya que por el hecho de ser un espárido, se les ha suministrado piensos de dorada. Esto supone un coste adicional en la alimentación del sargo, ya que como especie omnívora, los niveles de materias primas proteicas y lipídicas de origen animal, deberían ser inferiores a los de la dorada, cuyo máximo nivel de inclusión en el pienso en el caso de las harinas y turtós y concentrados proteicos sería de un $40 \%$ y de un $66 \%$ la sustitución del AP, sin que estas sustituciones afectaran los parámetros de crecimiento, niveles que elevan los costes de producción.

Para conocer con exactitud el nivel de reducción en la inclusión de fuentes animales en piensos para el sargo se han realizado únicamente tres trabajos con fuentes proteicas vegetales (Rondán et al., 2004; Chatzifotis et al., 2006; Hernández et al., 2007) y sólo se cuenta con un trabajo con fuentes lipídicas vegetales (Piedecausa et al., 2007).

Con los trabajos realizados en la presente tesis doctoral se pretende ofrecer materias primas alternativas, tanto a nivel proteico como lipídico, que no sólo reduzcan los precios de producción, sino a su vez no afecten la calidad nutricional ni a la salud de los peces, evaluada a través de la histología. 
Así, el objetivo general fue estudiar el efecto de la sustitución de la harina y el aceite de pescado por harinas y aceites alternativos en el crecimiento, parámetros nutritivos, composición corporal y salud del sargo picudo:

En la sustitución de la harina de pescado, el objetivo fue evaluar una fuente proteica económica como el turtó de girasol y un concentrado proteico, que obtuvo buenos resultados en otros espáridos, el concentrado proteico de guisante.

En la sustitución del aceite de pescado el objetivo fue evaluar la inclusión de una fuente lipídica vegetal con contenido de ácidos grasos poliinsaturados (aceite de soja) y otra animal con un alto contenido en ácidos grasos saturados y monoinsaturados. 
CAPÍTULO 3.

PLAN EXPERIMENTAL 



\section{CAPÍTULO 3. PLAN EXPERIMENTAL}

Dado que el sargo picudo tiene diferentes hábitos alimenticios en la fase de preengorde y en la de engorde, las pruebas se plantearon a su vez separando estas dos fases de crecimiento.

Los experimentos de la presente tesis doctoral se dividieron en dos grandes grupos:

1) Las pruebas donde se evaluó la inclusión de Turtó de Girasol (TG) y Concentrado Proteico de Guisante (CPG) en la alimentación del sargo picudo, estudiando los efectos sobre el crecimiento y la eficiencia nutritiva y a su vez sobre la salud del animal. Para ello, se emplearon en principio animales en fase de pre-engorde y posteriormente, con la fuente vegetal que dio un mejor crecimiento, se realizó un experimento en fase de engorde. Para una mejor comprensión de estos experimentos en la Figura 4.1, se muestra un resumen de éstos, así como los parámetros evaluados en cada una de las pruebas.

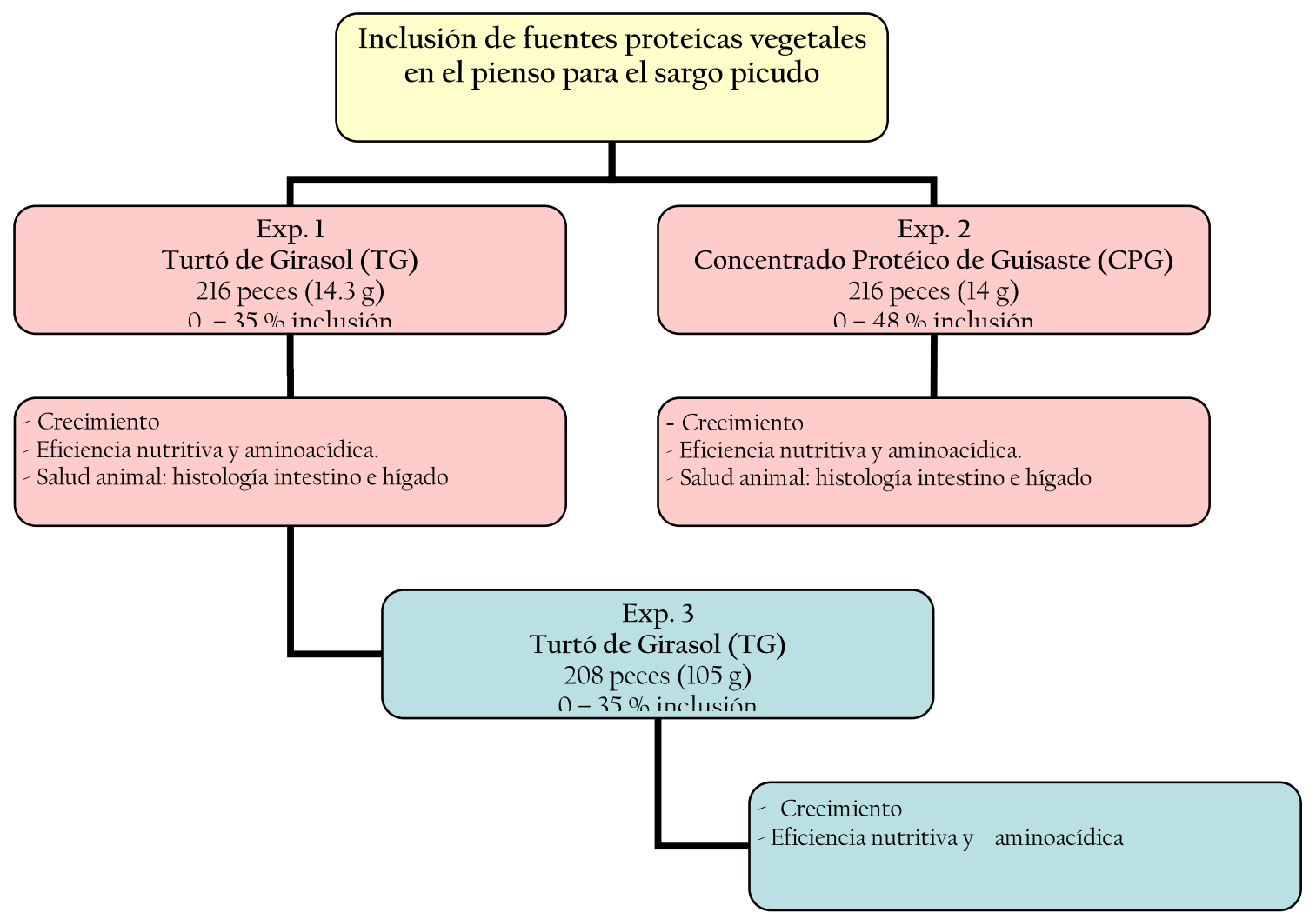

Figura 4.1. Resumen de los experimentos de inclusión de fuentes proteicas vegetales. 
2) Las pruebas donde se evaluó la inclusión de fuentes lipídicas en piensos. Se empleó una fuente con un alto contenido de PUFA, que es el aceite de soja (AS) y una fuente con un alto contenido de SFA y MUFA, que es la manteca de cerdo (MC). Los experimentos se llevaron a cabo con sargos picudos en fase de pre-engorde y al finalizar estos experimentos, se probó el 50\% de sustitución de AS y 50\% de MC con peces en fase de engorde. Todos los piensos se formularon incluyendo un $24 \%$ de TG, el cual obtuvo buenos índices de crecimiento en las pruebas anteriores. En la Figura 4.2, se detalla los tres experimentos realizados con la sustitución del aceite de pescado por las fuentes lipídicas alternativas.

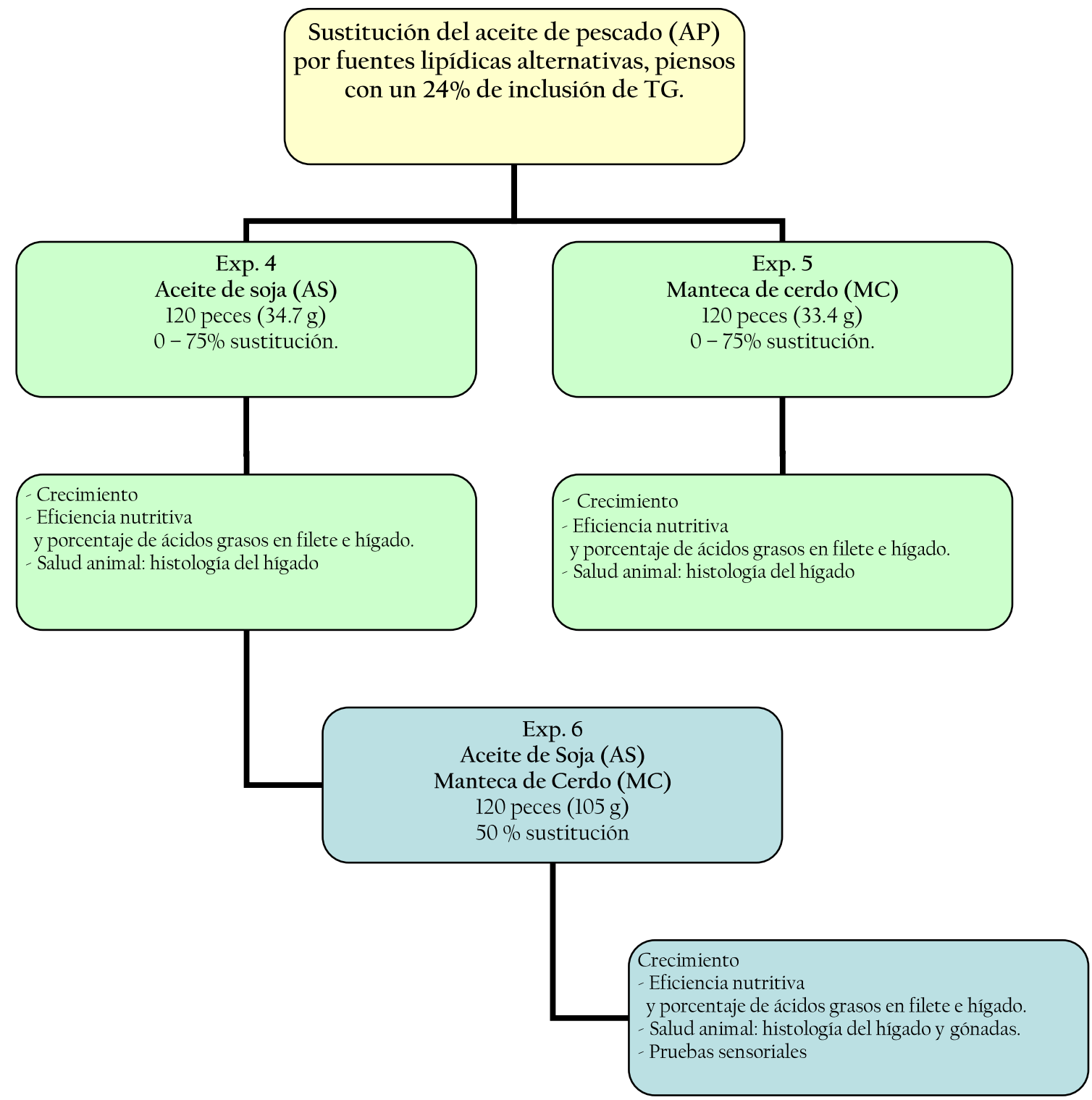

Figura 4.2. Resumen de los experimentos de sustitución del aceite de pescado por fuentes lipídicas alternativas. 
En cuanto a la valoración de la salud del animal, en los experimentos de fuentes proteicas en la fase de pre-engorde se realizó la histología tanto del intestino como del hígado de los sargos al final del ensayo. En los experimentos de fuentes lipídicas en la fase de pre-engorde sólo se realizó la histología del hígado, y en el experimento de fuentes lipídicas en fase de engorde se realizó la histología del hígado y las gónadas, para observar como las diferentes sustituciones o inclusiones afectaron a estos órganos.

Sólo se realizaron análisis sensoriales en el experimento de fuentes lipídicas fase de engorde, debido a que estos peces alcanzaron el tamaño comercial, realizándose la cata con panelistas no entrenados, empleándose el método de prueba triangular (ISO 4120, 1983). 



\section{CAPITULO 4.}

Sunflower meal as a partial substitute in juvenile sharpsnout sea bream (Diplodus puntazzo) diets: Aminoacids retention, gut and liver histology

Aquaculture: (2010) 298, 275 - 281. 



\section{Sunflower meal as a partial substitute in juvenile sharpsnout sea bream (Diplodus puntazzo) diets: Amino acid retention, gut and liver histology}

Silvia Nogales Mérida* , Ana Tomás-Vidal, Silvia Martínez-Llorens, Miguel Jover Cerdá

Institute of Animal Science and Technology, Aquaculture and Biodiversity Group, Polytechnic University of Valencia, Spain

A R T I C L E I N F O

\section{Article history:}

Received 4 September 2009

Received in revised form 27 October 2009

Accepted 28 October 2009

\section{Keywords:}

Diplodus puntazzo

Intestine histology

Liver

\section{A B S T R A C T}

The suitability of sunflower meal (SFM) as a substitute for fish meal was evaluated in sharpsnout sea bream fingerlings ( $14 \mathrm{~g}$ ) by feeding diets in which $0,10,20$ or $30 \%$ of crude protein provided by fish meal was substituted with SFM. The experiment lasted 125 days and survival at the end of the experiment was 95\% The effect of SFM level on growth parameters were not significant $(P<0.05)$. Fish were hand-fed to apparent satiation and feed intake ratio was not affected by SFM inclusion in the diet. Final live weight was $100 \mathrm{~g}$ for all fish fed all diets. Nutritional and biometric parameters were not affected by SFM substitution, but in body composition fish fed the diet with $20 \%$ of crude protein replaced by SFM substitution showed the lowest crude lipid level and the highest moisture content. Crude protein efficiency, gross energy efficiency and amino acid composition and retention of fish fed the various diets did not reach statistical differences. No histological alteration were found in liver, but an increment in goblet cells was observed in mucosa folds, perhaps as a consequence of SFM substitution or due to the high content of arginine and aspartate, known to be responsible for some immune responses. The results of this experiment demonstrated that SFM can supply up to $30 \%$ of crude protein in diets for feeding sharpsnout sea bream juveniles without any adverse effect on fish growth, liver and gut histology and amino acid composition and retention.

(c) 2009 Elsevier B.V. All rights reserved.

\section{Introduction}

Although all the Mediterranean sparidae fish appear as potentially interesting species for culture, the bream species are especially considered because of their satisfactory market price, good growth performance and easy adaptation to captivity. Sharpsnout sea bream is one of the most interesting species: experiments on breeding, rearing larvae and growth out in floating cages and ponds have been carried out in the Mediterranean area (García Gómez and Ortega Ros, 1993) and good growth results (Orban et al., 2000; Hernández et al., 2001; Favarolo et al., 2002) were obtained regarding sharpsnout sea bream, although more data should be collected to better understand the real potential of this fish. There is not much information about its nutritional requirements and the development of correct diets is essential to improve profitability in rearing this species.

It could be that fish with omnivorous feeding habits, such as sharpsnout sea bream (Sala and Ballesteros, 1997), could make a more efficient use of high levels of dietary vegetable protein. Some authors have reported on different aspects of the effects of fish meal substitution in this species, especially with plant protein substitution,

\footnotetext{
* Corresponding author. Polytechnic University of Valencia, Camino de Vera, 14 , 46071, Valencia, Spain. Tel: $+34963877007:$ fax: +34963877439

E-mail address: silvianogales@hotmail.com (S. Nogales Mérida).
}

although only alfalfa (Chatzifotis et al., 2006) and soybean meal (Rondán et al., 2004; Hernández et al., 2007) were assayed.

Sunflower meal (SFM) is highly palatable and has low antinutritional factors (a polyphenolic compound 1-3\%), but has low levels of lysine. In addition, it has high levels of fibre (18-23\%) and lignin. It has been used as an alternative plant protein to fish meal with good results but up to $30 \%$ maximum levels. Martínez (1984) used up to $22 \%$ of SFM in rainbow trout (Onchorynchus mykiss) diets without any adverse effect on fish growth. In Tilapia rendelli, the best results were obtained with $20 \%$ SFM substitution (Olvera-Novoa et al., 2002) and for Nile tilapia fingerlings, Furuya et al. (2000) obtained the best result with $14 \%$ of SFM. In Atlantic salmon, the SFM replacement was 33\% without any adverse effect on their performance (Gill et al., 2006). Recently, in another sparid fish, the gilthead sea bream showed best results with $12 \%$ SFM replacement (Sanchez-Lozano et al., 2007).

Fish meal substitution by protein sources has been implemented in recent decades, but little is known about their effects on fish morphology and possible repercussions on fish health and behaviour. Hansen et al. (2006) studied the effects of plant protein inclusion in Gadus morhua, reporting no histological alteration either in gut or liver. Similar results were reported by Daprà et al. (2009), who partially replaced rice protein concentrate meal in Pagellus bogaraveo experimental diets. The effects of fish meal substitution by soybean meal on the intestinal tract of Salmon salar have been studied by Baeverfjord and Krogdahl (1996), Sanden et al. (2005), Bakke- 
McKellep et al. (2007), Uran et al. (2009) and Øverland et al. (2009) with consistent reporting of enteritis caused by this plant meal substitution. At the same time, Uran et al. (2008) reported intestinal inflammation caused by soybean meal in Cyprimus carpio $\mathrm{L}$.

The relation of amino acid composition, retention of nutrients ingested and their interaction in the intestine and liver of sharpsnout sea bream is not certainly known, so the aim of this experiment was to study the introduction of sunflower meal protein in juvenile sharpsnout sea bream diets and study the effects on growth, nutrient utilisation, body composition, amino acid retention and histological alteration in liver and gut that could be caused by this plant meal substitution.

\section{Material and methods}

\subsection{Production system}

The trial was conducted for 125 days in 12 pens distributed in four cylindrical fiberglass tanks (750 I) set up in a recirculation marine water system ( $30 \mathrm{~m}^{3}$ capacity) with a rotary mechanical filter and a gravity bio pump filter of around $30 \mathrm{~m}^{3}$ capacity. All tanks were equipped with aeration and the water was heated by a heat pump installed in the system. Average water temperature was $22.2 \pm 2^{\circ} \mathrm{C}$, salinity was $33.4 \mathrm{gl}^{-1}$, dissolved oxygen was $6.3 \pm 0.5 \mathrm{mg} \mathrm{l}^{-1}$ and $\mathrm{pH}$ ranged from 7 to 8 . Photoperiod was natural and all tanks had similar light conditions.

\subsection{Fish and feeding regime}

Sharpsnout sea bream (Diplodus puntazzo) fingerlings were obtained from an Italian commercial hatchery and acclimated to laboratory conditions for 8 weeks prior to the feeding experiment. During this period, fish were fed on a standard commercial sea bream diet (48\% crude protein CP; $23 \%$ crude lipid CL; $11 \%$ ash; $2.2 \%$ crude fibre CF and 14\% nitrogen free extract NFE) (Dibaq S.A., SegoviaSpain). Groups of $18 \mathrm{fish}, 14 \mathrm{~g}$ in mean weight, were distributed in cages (three cages per treatment), each cage with a $98 \mathrm{I}$ volume inside a tank of $750 \mathrm{I}$ capacity. Replicates were randomly selected.

\subsection{Diets and feeding}

Four isolipidic and isoproteic diets (20\% CL, $45 \% \mathrm{CP})$ were formulated using commercial ingredients (Table 1), in which CP from fish meal and wheat were substituted with sunflower meal (Table 2 ) at 0 (control diet), 10, 20 and $30 \%$ of total CP. Diets were prepared by cookingextrusion processing with a semi-industrial twin-screw extruder (CLEXTRAL BC-45, St. Etienne, France). Processing conditions were as follows: $100 \mathrm{rpm}$ speed screw, $110^{\circ} \mathrm{C}$ temperature, $30-40 \mathrm{~atm}$ pressure and 1 and $2 \mathrm{~mm}$ diameter pellets, according to fish size.

Fish were fed by hand twice a day $(09.00$ and 16.00) with the experimental diets to apparent satiation for 125 days (February to June). Pellets were distributed slowly, allowing all fish to eat. All fish were anaesthetised with clove oil at $30 \mathrm{mg} \mathrm{L}^{1}$, containing $87 \%$ of euglenol (Guinama $®$, Valencia Spain) and individually weighed every 30 days. At the end of growth trials, five fish per cage were removed to determine biometric parameters and stored at $-30^{\circ} \mathrm{C}$ for whole body composition, and three guts and livers per cage were also collected for histological analysis.

\subsection{Proximate composition and amino acid analysis}

Chemical analyses of the dietary ingredients were determined prior to diet formulation. Diets and their ingredients as well as the whole fish were analysed according to AOAC (1990) procedures: dry matter $\left(105^{\circ} \mathrm{C}\right.$ to constant weight), ash (incinerated at $550{ }^{\circ} \mathrm{C}$ to constant weight), crude protein $(N \times 6.25)$ by the Kjeldahl method
Table 1

Proximate composition and amino acids content of the main ingredients used in the experimental diets (expressed on a dry-matter (DM) basis).

\begin{tabular}{|c|c|c|c|}
\hline International feed number & $\begin{array}{l}\text { Fish meal, herring } \\
(5-02-000)\end{array}$ & $\begin{array}{l}\text { Wheat } \\
(4-05-268)\end{array}$ & $\begin{array}{l}\text { Sunflower meal } \\
(5-04-739)\end{array}$ \\
\hline \multicolumn{4}{|c|}{ Proximate composition of ingredients used in experimental diets } \\
\hline Dry matter (\%) & 91.14 & 88.10 & 89.34 \\
\hline Crude protein (\% DM) & 74.51 & 13.10 & 34.98 \\
\hline Crude lipid (\% DM) & 9,31 & 1.79 & 1.19 \\
\hline Crude fibre (\% DM) & na & 3.25 & 23.63 \\
\hline Ash (\% DM) & 16.94 & 1.88 & 6.95 \\
\hline N-free extract (\% DM) ${ }^{\mathrm{a}}$ & na & 79.98 & 33.25 \\
\hline \multicolumn{4}{|c|}{ Essential amino acid content calculated as $g 100^{-1} g$} \\
\hline Arginine & 6.18 & 0.50 & 3.02 \\
\hline Histidine & 2.66 & 0.28 & 1.07 \\
\hline Isoleucine & 3.54 & 0.42 & 1.66 \\
\hline Leucine & 5.66 & 0.76 & 2.38 \\
\hline Lysine & 4.43 & 0.36 & 1.06 \\
\hline Methionine & 1.63 & 0.12 & 0.58 \\
\hline Phenylalanine & 4.93 & 0.58 & 2.28 \\
\hline Threonine & 3.60 & 0.36 & 1.43 \\
\hline Valine & 3.86 & 0.51 & 1.89 \\
\hline \multicolumn{4}{|c|}{ Nonessential amino acid content calculated as g $100^{-1} \mathrm{~g}$} \\
\hline Alanine & 4.45 & 0.44 & 1.56 \\
\hline Aspartate & 6.33 & 0.62 & 3.14 \\
\hline Cystine & 1.01 & 0.31 & 1.15 \\
\hline Glutamine & 8.99 & 3.37 & 6.84 \\
\hline Glycine & 5.36 & 0.52 & 2.51 \\
\hline Proline & 7.06 & 1.27 & 3.25 \\
\hline Serine & 2.98 & 0.55 & 1.70 \\
\hline Tyrosine & 3.60 & 0.15 & 0.96 \\
\hline EAA/NEAA & 0.92 & 0.54 & 0.73 \\
\hline
\end{tabular}

not analysed.

a $\%$ NFE $=100-\%$ CP-\%CL-\%Ash-\%CF

Table 2

Ingredient and proximate composition of experimental diets.
The

\begin{tabular}{|c|c|c|c|c|}
\hline \multirow[b]{2}{*}{ Ingredients $\left(\mathrm{g} \mathrm{kg}^{-1}\right)$ (IFN) } & \multicolumn{4}{|c|}{$\begin{array}{l}\% \text { of dietary crude protein supplied by } \\
\text { Sunflower meal }\end{array}$} \\
\hline & 0 & 10 & 20 & 30 \\
\hline Fish meal, herring (5-02-000) & 550 & 502 & 454 & 406 \\
\hline Sunflower meal(5-04-739) & & 117 & 235 & 352 \\
\hline Wheat $(4-05-268)$ & 239 & 167 & 94 & 23 \\
\hline Soybean oil (4-07-983) & 51 & 51 & 51 & 51 \\
\hline Fish oil $(7-08-048)$ & 100 & 103 & 106 & 108 \\
\hline Maltodextrin & 50 & 50 & 50 & 50 \\
\hline Vitamin mix ${ }^{a}$ & 6.3 & 6.3 & 6.3 & 6.3 \\
\hline Vitamin $C^{a}$ & 1.5 & 1.5 & 1.5 & 1.5 \\
\hline Mineral mix & 2.2 & 2.2 & 2.2 & 2.2 \\
\hline \multicolumn{5}{|c|}{ Analysed composition (\% dry weight) } \\
\hline Dry matter (DM) & 91.99 & 87.30 & 91.81 & 92.29 \\
\hline Crude protein (CP) & 42.16 & 43.26 & 43.09 & 44.69 \\
\hline Crude lipid (CL) & 18.80 & 19.79 & 20.04 & 20.12 \\
\hline Ash & 10.04 & 10.08 & 10.30 & 10.17 \\
\hline Crude fibre (CF) & 0.48 & 2.28 & 4.85 & 7.44 \\
\hline \multicolumn{5}{|l|}{ Calculated values } \\
\hline $\mathrm{N}$-free extract (\% NFE) ${ }^{c}$ & 28.52 & 24.59 & 21.72 & 17.58 \\
\hline GE $\left(M J \mathrm{~kg}^{-1}\right)^{\mathrm{d}}$ & 22.6 & 22.5 & 22.1 & 21.8 \\
\hline $\left.\mathrm{CP} / \mathrm{GE}(\mathrm{g} \mathrm{M})^{-1}\right)^{d}$ & 18.7 & 19.2 & 19.5 & 20.5 \\
\hline
\end{tabular}

a Vitamin and mineral mix (values are $\mathrm{g} \mathrm{kg}^{-1}$ except those in parenthesis): Premix: 25: Choline, 10; ol- $\alpha$ tocopherol, 5; ascorbic acid, 5; $\left(\mathrm{PO}_{4}\right)_{2} \mathrm{Ca}_{3}$, 5. Premix composition: retinol acetate, $1,000,000 \mathrm{IU} \mathrm{kg}{ }^{-1}$; calcipherol, $500 \mathrm{IU} \mathrm{kg}^{-1}$; DL-atocopherol, 10 ; menadione sodium bisulphite, 0.8 ; thiamin hydrochloride, 2.3 ; riboflavin, 2.3 ; pyridoxine hydrochloride, 15; cyanocobalamin, 25; nicotinamide, 15; pantothenic acid, 6; folic acid, 0.65; biotin, 0.07; ascorbic acid, 75; inositol, 15; betaine, 100; polypeptides 12. (Dibaq-Diproteg).

${ }^{b} \mathrm{Zn}, 5 ; \mathrm{Se}, 0.02 ; 1,0,5 ; \mathrm{Fe}, 0.2 ; \mathrm{Cu0}, 15 ; \mathrm{Mg}, 5.75 ; \mathrm{Co}, 0.02 ;$ Met, 1.2; Cys, 0.8; Lys, 1.3 ; Arg, 0.6; Phe, 0.4; Trcp, 0.7; excpt. $1000 \mathrm{~g}$ (Dibaq-Diproteg).

c \%NFE $=100-\%$ CP-\%CL-\%Ash-\%CF.

${ }^{d} \mathrm{CE}$ : Gross energy: calculated using: $23.9 \mathrm{~kJ} \mathrm{~g}^{-1}$ proteins, $39.8 \mathrm{~kJ} \mathrm{~g}^{-1}$ lipids and $17.6 \mathrm{~kJ} \mathrm{~g}^{-1}$ carbohydrates, 
after an acid digestion (Kjeltec 2300 Auto Analyser, Tecator Höganas, Sweden), crude lipid extracted with methyl-ether (Soxtec 1043 extraction unit, Tecator) and crude fibre by acid and basic digestion (Fibertec System M., 1020 Hot Estractor, Tecator). All analyses were performed in triplicate.

Following the method previously described by Bosch et al. (2006) amino acids of fish carcass and diets were analysed through a Waters HPLC system (Waters 474, Waters, Milford, MA, USA) consisting of two pumps (Model 515, Waters), an auto sampler (Model 717 , Waters), a fluorescence detector (Model 474, Waters) and a temperature control module. Aminobutyric acid was added as an internal standard pattern before hydrolysation. The amino acids were derivatised with $\mathrm{AQC}$ (6-aminoquinolyl-N-hydroxysuccinimidyl carbamate). Methionine and cysteine were determined separately as methionine sulphone and cysteic acid after oxidation with performic acid. Amino acids were separated with a C-18 reverse-phase column Waters Acc. Tag ( $150 \mathrm{~mm} \times 3.9 \mathrm{~mm})$, and then transformed to methionine and cystine.

\subsection{Histological analysis}

The gastrointestinal tracts collected were divided into three parts: 1) Anterior intestine (AI), 2) Mid intestine (MI), 3) Posterior intestine (PI). Tissue samples were fixed in phosphate buffered formalin $(4 \% \mathrm{pH}$ 7.4) and then transferred to $70 \%$ ethanol for storage until processing. All formalin fixed tissues were routinely dehydrated in ethanol, equilibrated in Ultraclear ${ }^{\mathrm{TM}}$ and embedded in paraffin according to standard histological techniques. Eighteen longitudinal sections (approximately $5 \mu \mathrm{m}$ thick) of anterior, mid and posterior intestines per treatment were cut and stained with haematoxylin and eosin (HE). Processing of the tissues took place at the Histology section of the Animal Science Department of the Polytechnic University of Valencia (Spain). Blinded histological examination was performed by light microscopy (Nikon Phase Contrast 0.90 Dry Japan). Tissue morphology was assessed according to Baeverfjord and Krogdahl (1996) as well as Lundstedt's (2004) methodology, but in liver morphology evaluation the McFadzen et al. (1997) criteria were used, in addition to quantification of hepatocytes, to observe possible alterations revealed through differences in the hepatocyte condition or hepatic cell morphology.

\subsection{Statistical analysis}

Growth data and nutritive parameters were treated using multifactor analysis of variance (ANOVA), introducing the initial live weight as covariate (Snedecor and Cochran, 1971). Newman-Keuls test was used to assess specific differences among diets at a significance levels of $P<0.05$ significance levels (Statgraphics, Statistical Graphics System, Version Plus 5.1, Herndon, Virginia, USA).

The number of hepatocytes was quantified per area $\left(125.000 \mu \mathrm{m}^{2}\right)$ at the same time as the length and width of the mucosa fold, and the numbers of mucus cells were analysed with a simple ANOVA. Histological analysis of hepatocytes and acinar cells was performed using the methodology of McFadzen et al. (1997) and evaluated by a Cross Tabulation and Chi Square contrast $\left(X^{2}\right)$ on Statgraphics.

\section{Results}

\subsection{Growth performance and biometric analysis.}

Amino acid profiles were similar in all experimental diets (Table 3). The relationship between essential (EAA) and nonessential (NEAA) amino acids ranged from 0.89-0.93 in all diets.

Fish survival was $95 \%(P<0.05)$ during the experimental period and there was no statistical difference among groups.
Table 3

Total amino acid composition $\left(\mathrm{g} 100^{-1} \mathrm{~g}\right.$ ) of experimental diets in dry weight.

\begin{tabular}{lllll}
\hline & \multicolumn{4}{c}{ \% of dietary crude protein supplied by Sunflower meal } \\
\cline { 2 - 5 } Amino acids & 0 & 10 & 20 & 30 \\
\hline Essential amino acids & & & & \\
Arginine & 3.13 & 3.74 & 3.25 & 3.19 \\
Histidine & 1.24 & 1.45 & 1.25 & 1.22 \\
Isoleucine & 1.93 & 1.97 & 1.92 & 1.92 \\
Leucine & 3.42 & 3.47 & 3.12 & 3.09 \\
Lysine & 3.72 & 3.54 & 2.95 & 2.95 \\
Methionine & 1.30 & 1.09 & 1.17 & 1.04 \\
Phenylalanine & 1.68 & 2.18 & 1.83 & 1.75 \\
Threonine & 1.99 & 2.18 & 1.90 & 1.83 \\
Valine & 2.25 & 2.28 & 2.22 & 2.24 \\
& & & & \\
Nonessential amino acids & & & & \\
Alanine & 2.86 & 2.70 & 2.50 & 2.47 \\
Aspartate & 4.28 & 4.51 & 3.85 & 3.98 \\
Cystine & 1.44 & 1.10 & 1.06 & 1.20 \\
Glutamine & 6.76 & 7.02 & 6.40 & 6.67 \\
Glycine & 2.67 & 3.05 & 2.64 & 2.62 \\
Proline & 2.00 & 2.40 & 1.80 & 1.76 \\
Serine & 1.93 & 2.13 & 1.75 & 1.77 \\
Tyrosine & 1.29 & 1.65 & 1.20 & 1.09 \\
EAA/NEAA & 0.89 & 0.89 & 0.93 & 0.89 \\
\hline
\end{tabular}

The evolution of fish weight gain showed a marked weight increase and similar fish growth among treatments. In Table 4, the different growth parameters demonstrated no statistical differences $(P<0.05)$ among experimental diets. SGR fluctuated from 1.55 to $1.58 \%$ day $^{-1}$ and TGC ranged from 1.74 to 1.82 among treatments. In feed efficiency there were no statistical differences.

In relation to biometric parameters (Table 4 ), none of those studied showed significant differences $(P<0.05)$.

Table 4

Response of sharpsnout sea bream fed diets containing different percentage of total crude protein (CP) from sunflower meal for 125 days.
cosponse of sharpsnout sea bream fed diets containing

\begin{tabular}{|c|c|c|c|c|c|c|}
\hline & \multicolumn{6}{|c|}{$\%$ of dietary crude protein supplied by Sunflower meal } \\
\hline & 0 & 10 & 20 & 30 & SEM & $P$-value \\
\hline Initial weight ( $\mathrm{g}$ ) & 14.1 & 14.7 & 14.0 & 14.6 & 0.33 & 0.34 \\
\hline Final weight (g) & 103 & 100 & 100 & 104 & 3.02 & 0.75 \\
\hline $\operatorname{SGR}\left(\% \mathrm{day}^{-1}\right)^{\mathrm{a}}$ & 1.58 & 1.55 & 1.56 & 1.58 & 0.02 & 0.73 \\
\hline $\mathrm{TGC}^{\circ}$ & 1.82 & 1.74 & 1.80 & 1.80 & 0.04 & 0.57 \\
\hline $\mathrm{FI}\left(\mathrm{g} 100 \mathrm{~g} \mathrm{fish}^{-1} \mathrm{day}^{-1}\right)^{c}$ & 2.16 & 2.20 & 2.27 & 2.11 & 0.11 & 0.77 \\
\hline $\mathrm{FCR}^{\mathrm{d}}$ & 1.91 & 1.93 & 1.98 & 1.85 & 0.10 & 0.78 \\
\hline $\mathrm{PER}^{e}$ & 1.36 & 1.37 & 1.29 & 1.31 & 0.06 & 0.75 \\
\hline $\mathrm{CF}^{f}$ & 1.91 & 1.83 & 1.90 & 2.02 & 0.10 & 0.64 \\
\hline $\mathrm{HSI}^{\mathrm{g}}(\%)$ & 0.96 & 1.01 & 0.80 & 0.96 & 0.11 & 0.52 \\
\hline $\mathrm{MF}^{\mathrm{h}}(\%)$ & 1.17 & 1.33 & 1.26 & 1.44 & 0.15 & 0.64 \\
\hline $\mathrm{ISI}^{1}(\%)$ & 1.66 & 1.81 & 2.10 & 1.66 & 0.26 & 0.59 \\
\hline VSH( $(\%)$ & 6.53 & 6.90 & 6.93 & 6.96 & 0.30 & 0.72 \\
\hline $\mathrm{DP}^{\mathrm{k}}(\%)$ & 78.6 & 77.4 & 77.5 & 78.6 & 0.70 & 0.65 \\
\hline
\end{tabular}

Data in the same row with different superscripts differ at $P<0.05$. (mean \pm S.E.M. $n=3$ ) initial weight in each phase was considered as covariable for live weight and SGR a Specific growth rate $\left(\%\right.$ day $\left.^{-1}\right), S G R=100 \times \ln$ (final weight/initial weight)/days. ${ }^{b}$ Thermal Growth Coefficient $\left(\right.$ TGC) $=1000^{*}\left[\mathrm{FW}^{1 / 3}-\mathrm{IW}^{1 / 3}\right] /\left(T^{0}-\right.$ minimum $T^{0}$ to feed).

Feed Intake ratio ( $\mathrm{g} 100 \mathrm{~g} \mathrm{fish}^{-1} \mathrm{day}^{-1}$ ), Fl=100 $\times$ feed consumption ( $\mathrm{g}$ )/average biomass $(\mathrm{g}) \times$ days.

d Feed Conversion ratio, $\mathrm{FCR}=$ feed offered $(\mathrm{g}) /$ biomass gain $(\mathrm{g})$.

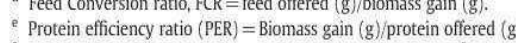

${ }^{\mathrm{f}}$ Condition Factor $(\mathrm{CF})=\left[\right.$ body weight $(\mathrm{g}) /$ total length $\left.(\mathrm{cm})^{3}\right] \times 100$.

Hepatosomatic index $(\mathrm{HSI})=[$ liver weight $(\mathrm{g}) /$ body weight $(\mathrm{g})] \times 100$.

${ }^{\mathrm{h}}$ Mesenteric fat $(\mathrm{MF})=[$ mesenteric fat weight $(\mathrm{g})$ /body weight $(\mathrm{g})] \times 100$.

${ }^{\prime}$ Intestine somatic index (ISI) $=[$ intestine weight $(\mathrm{g}) /$ body weight $(\mathrm{g})] \times 100$.

${ }^{3}$ Viscerosomatic index (VSI) $=100 \times$ [visceral weight ( $g$ )/fish weight $(\mathrm{g})$ ].

${ }^{k}$ Dressout percentage (DP) $=100 \times$ [total fish weight $(g)$ - visceral weight $(g)$ - head weight $(\mathrm{g})] /$ fish weight $(\mathrm{g})$. 
Table 5

Proximate composition and protein and energy conversion efficiency of Diplodus puntazzo fed the experimental diets.

\begin{tabular}{|c|c|c|c|c|c|c|c|}
\hline & \multicolumn{7}{|c|}{ \% of dietary crude protein supplied by Sunflower meal } \\
\hline & Initial & 0 & 10 & 20 & 30 & SEM & $P$-value \\
\hline Moisture (\%) & 69.4 & $63.6^{a}$ & $63.7^{\mathrm{a}}$ & $64.7^{b}$ & $63.1^{a}$ & 0.2 & 0.03 \\
\hline Crude protein (\% ww) & 15.2 & 17.2 & 17.4 & 17.3 & 17.3 & 0.1 & 0.54 \\
\hline Crude lipid (\% ww) & 11.2 & $14.8^{\mathrm{b}}$ & $13.5^{\mathrm{ab}}$ & $12.3^{\mathrm{a}}$ & $13.7^{\mathrm{ab}}$ & 0.4 & 0.34 \\
\hline Ash $(\%$ ww) & 4.4 & 3.7 & 3.8 & 4.1 & 3.9 & 0.1 & 0.22 \\
\hline CPE (\%) & 24.0 & 24.6 & 22.9 & 23.3 & 1.2 & 0.77 & \\
\hline $\operatorname{GEE}(\%)^{2}$ & 26.4 & 25.9 & 23.2 & 26.9 & 1.8 & 0.53 & \\
\hline
\end{tabular}

Values are the mean \pm S.E.M $(n=3)$. The same letters are not different $(P>0.05)$. Newman-Keuls test.

${ }^{y}$ Grude protein efficiency, CPE $(\%)=$ increment of protein corporally $(g) \times 100$ protein ingestion $(g)$.

${ }_{z}$ Gross energy efficiency, GEE $(\%)=$ increment of energy corporally $(\mathrm{kJ}) \times 100$ energy ingestion $(\mathrm{k})$.

\subsection{Whole - body composition and retention}

Carcass composition at the end of the trial is shown in Table 5. There were statistical differences $(P<0.05)$ in moisture and $\mathrm{Cl}$ : fish fed the $20 \%$ SFM substitution obtained the highest moisture content (64.7\%) as well as the lowest $\mathrm{CL}$ value (12.3\%). In CP, and ash there were no statistical differences among treatments. For amino acids in fish body composition (Fig. 1), statistical differences $(P<0.05)$ were only observed for valine and leucine, increasing as SFM substitution

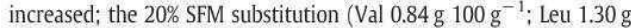
$100 \mathrm{~g}^{-1}$ ) obtained the highest values.

No statistical differences $(P<0.05)$ were found among treatments in protein and energy retention (Table 5). As in amino acid retention (Fig. 2), no statistical differences were found among treatments, only a slight fluctuation.

\subsection{Liver and intestine morphology.}

Inclusion of SFM in the diet did not cause fish liver alterations, as seen in comparison of hepatocyte nuclei, cytoplasm, hepatic vacuolation and pancreatic acinar cells (Fig. 3 ) showed that the liver in all treatments suffered the same moderate nuclear atrophy and a slight granular texture in cytoplasm, with small vacuoles, while most of the pancreatic acinar cells showed distinct acini and pale nuclei (Fig, 4). There were no statistical differences in hepatocyte nuclei (HN) hepatocyte cytoplasm (HC), hepatic vacuolation (HV) and pancreatic

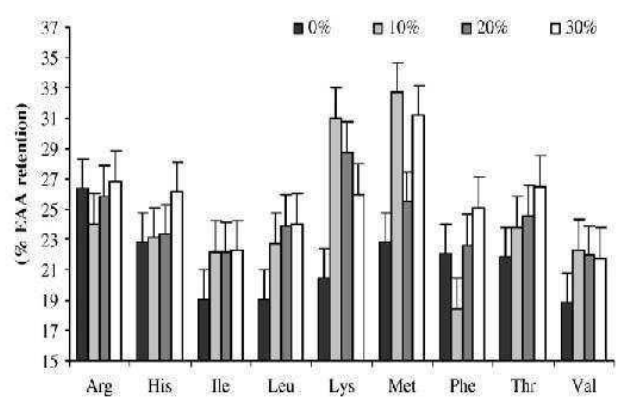

Fig. 2. Percentage of essential amino acid (EAA) retention in D. puntazzo juveniles fed with the different experimental diets for 125 days. Data with different superscripts differ at $P<0.05$ (means \pm SEM; $n=3$ ). Calculated according to: IAA retention (\%) = (amino acid gain $(\mathrm{g}) /$ amino acid intake $(\mathrm{g})) \times 100$.

acinar cells (PAC). Hepatocyte quantification (Table 6) showed no statistical differences among treatments $(P<0.05)$.

Intestinal segments (Table 6) appeared normal and did not show statistical differences $(P<0.05)$ among treatments in length, but a clear elongation of villi was notable compared with the control diet, while comparing fold lengths among intestine portions the PI exhibited the longest villi and the MI the shortest (Fig. 5). Lamina Propria (LP) in the Al portion became wider as SFM inclusion increased, and in the other portions presented fluctuations between treatments. Muscularis thickness in $\mathrm{Al}$ was less in the 0 and 30\% diets treatments; in Ml fish fed the $10 \%$ diet was the thickest and PI was similar in all treatments. Goblet cells in MI presented statistical differences in fish fed the $10 \%$, where the largest number of cells was obtained.

\section{Discussion}

Sunflower meal (SFM) inclusion in the diet did not affect fish survival during the experimental period. Similar results were reported by Furuya et al. (2000), who replaced SFM up to $28 \%$ in Nile Tilapia and Gill et al (2006) who replaced SFM up to $20 \%$ in Atlantic salmon with high fish survival. However, Chatzifotis et al. (2006) registered low survival rates among juvenile sharpsnout sea bream fed alfalfa as protein source. Most of the fish deaths recorded in this experiment were due to the aggressive behaviour of $D$. puntazzo towards its co-specifics for both space and food, facts already reported by Karakatsouli et al. (2006) and Favarolo
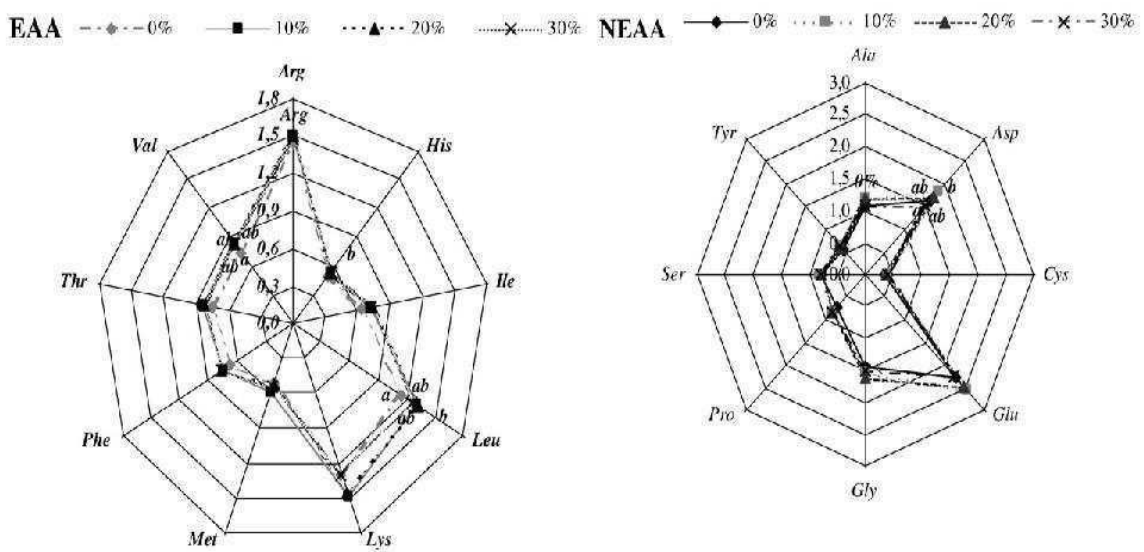

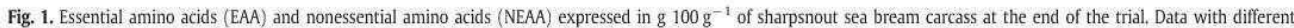
superscripts differ at $P<0.05$ (mean \pm S.E.M.; $n=3$ ) 


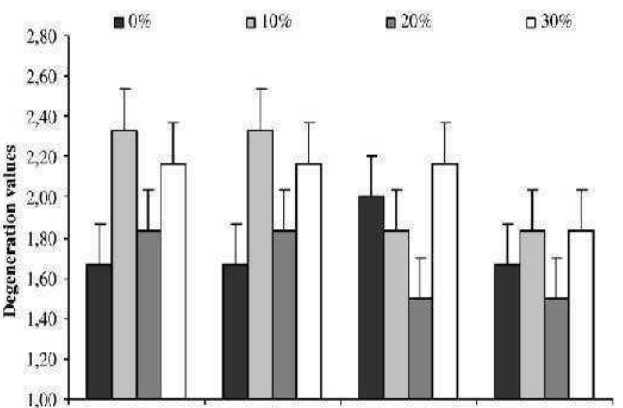

$\mathrm{LN}$

LHC

PAC

Fig. 3. Liver status of sharpsnout sea bream fed the different experimental diets based on the methodology of McFadzen et al. (1997). LN = hepatocyte nuclei; $\mathrm{HC}=$ hepatocyte cytoplasm; $\mathrm{HV}=$ hepatic vacuolation and $\mathrm{PAC}=$ pancreatic acinar cells. Data with different superscripts differ at $P<0.05$ (means \pm SEM; $n=3$ ).

et al. (2002), who indicated that this behaviour is especially common when they are in monoculture conditions.

The amino acids profile of all experimental diets was well balanced, as shown by growth and feed efficiency parameters. Likewise, arginine has been associated with fish growth (Fournier et al., 2002) and, combined with methionine, is known to be responsible for protein synthesis (Li et al., 2007).

Growth parameters (final weight and SGR) were different from those reported by Sanchez-Lozano et al. (2007), who, during their experimental phase with Sparus aurata, recorded fish growth inversely proportional to SFM substitution. However, in a salmonid species, such

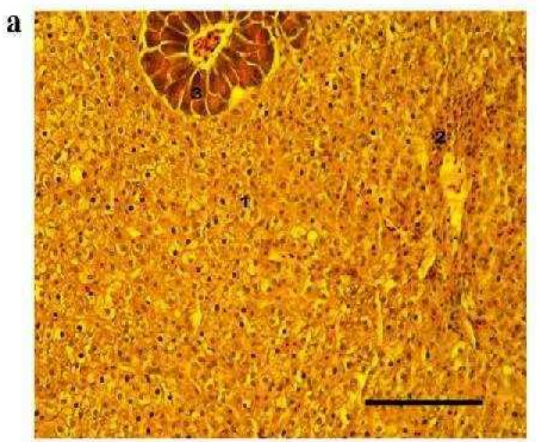

b

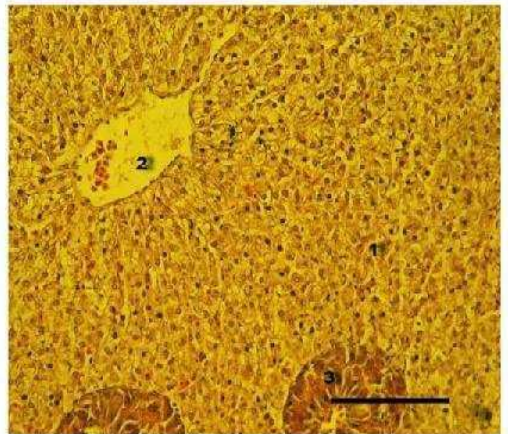

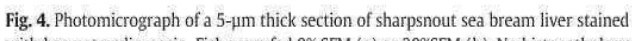
with haematoxylin-eosin. Fish were fed $0 \%$ SFM (a) or 30\%SFM (b). No histopathology was observed among treatments (photo at 20x): (1) hepatocytes; (2) blood vessel; (3) acinar cells.

Table 6

Histological values of liver and intestine of sharpsnout sea bream juveniles at the end of the trial.

\begin{tabular}{|c|c|c|c|c|c|c|}
\hline & \multicolumn{6}{|c|}{$\begin{array}{l}\text { \% of dietary crude protein supply by Sunflower meal } \\
\text { substitution }\end{array}$} \\
\hline & 0 & 10 & 20 & 30 & SEM & $P$-value \\
\hline Hepatocytes $^{3}$ & 859 & 782 & 808 & 898 & 51.8 & 0.44 \\
\hline \multicolumn{7}{|c|}{ Villi length $(\mu \mathrm{m})$} \\
\hline A.I. & 658.2 & 827.0 & 862.0 & 747.6 & 100.7 & 0.52 \\
\hline M.I. & 549.0 & 671.7 & 677.7 & 584.7 & 71.7 & 0.53 \\
\hline P.I. & 835.3 & 902.7 & 932.0 & 997.7 & 79.8 & 0.57 \\
\hline \multicolumn{7}{|c|}{ Lamina propria width $(\mu \mathrm{m})$} \\
\hline A.I. & 14.3 & 17.9 & 20.3 & 20.6 & 4.0 & 0.66 \\
\hline M.I. & 17.2 & 18.2 & 16.7 & 14.1 & 3.13 & 0.82 \\
\hline P.I. & 27.7 & 15.0 & 19.8 & 23.0 & 3.95 & 0.22 \\
\hline \multicolumn{7}{|c|}{ Villi width $(\mu m)$} \\
\hline A.1. & 103.1 & 127.1 & 131.7 & 98.4 & 11.5 & 0.18 \\
\hline M.I. & 99.0 & 124.1 & 119.2 & 90.1 & 8.3 & 0.06 \\
\hline P.I. & 146.3 & 118.6 & 124.8 & 122.8 & 12.4 & 0.44 \\
\hline \multicolumn{7}{|c|}{ Muscularis thickness $(\mu \mathrm{m})$} \\
\hline A.I. & 32.3 & 50.7 & 52.4 & 32.5 & 7.2 & 0.15 \\
\hline M.I. & 41.9 & 51.3 & 37.2 & 34.5 & 4.8 & 0.15 \\
\hline P.I. & 43.7 & 42.7 & 44.8 & 44.5 & 4.1 & 0.98 \\
\hline \multicolumn{7}{|c|}{ Goblet cells (number of cells per segment) } \\
\hline A.l. & 640 & 777 & 672 & 596 & 122.1 & 0.76 \\
\hline M.I. & $547^{\mathrm{a}}$ & $836^{b}$ & $482^{a}$ & $503^{\mathrm{a}}$ & 76.9 & 0.04 \\
\hline P.I. & 573 & 910 & 742 & 1034 & 139.2 & 0.18 \\
\hline
\end{tabular}

Values are the mean

$\mathrm{Al}=$ anterior intestine; $\mathrm{MI}=$ mid intestine; $\mathrm{Pl}=$ posterior intestine.

'Ouantity of hepatocytes per area $\left(125.000 \mathrm{um}^{2}\right)$.
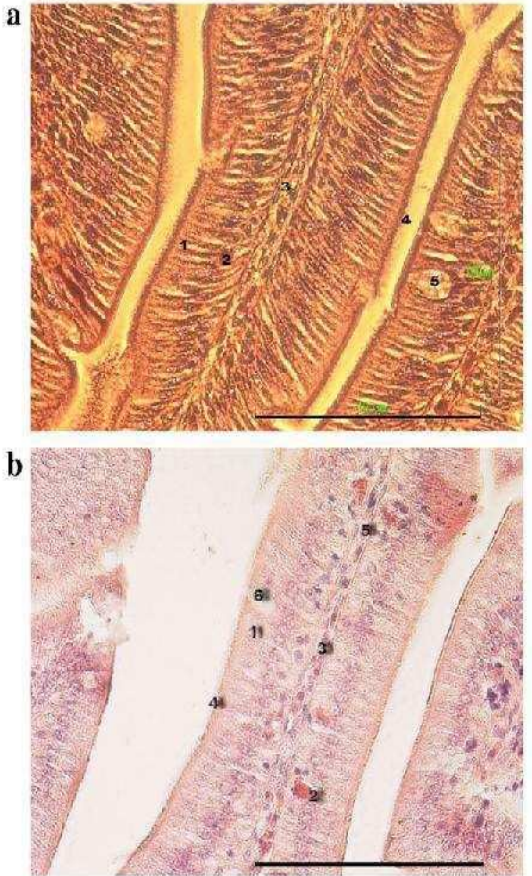

Fig. 5. Histological details of the haematoxylin-eosin stained medium villous folds 5 - $\mu \mathrm{m}$ thick) of D. puntazzo fed the diet with $0 \%$ SFM (a) or $30 \%$ SFM (b) at $20 \times$ : (1) enterocytes. (2) granulocytes (3) microvilli. (4) (5) Lamina propria (6) goblet cells. 
as Salmo salar fed with a maximum of $20 \%$, SFM did not cause any adverse effect in growth (Gill et al., 2006), although Furuya et al. (2000) obtained better results with a maximum of $14 \%$ of SFM replacement in Nile Tilapia, attributing lower growth to high fibre level with SFM substitution.

Regarding feed utilisation in sharpsnout sea bream, no level of SFM substitution resulted in statistical differences, and similar results were reported by Hernández et al. (2007) with soybean meal. In contrast. Chatzifotis et al. (2006), who studied different plant meal substitutions, obtained inversely proportional results with statistical differences between treatments and observed that high plant meal substitution resulted in worse FCR values. Similar results were obtained by Sanchez-Lozano et al. (2007), who considered the high fibre levels in plant meal affected fish growth and feed utilisation.

In summary, there are different criteria used by many researchers that have worked with SFM. For example Sanchez-Lozano et al (2007) advised the use of $12 \%$ as a maximum substitution, while in freshwater fish, Furuya et al. (2000) recommended 14\%, although Olvera-Novoa et al, (2002) and Gill et al. (2006), both working with freshwater species, considered $20 \%$ SFM as an optimum plant mea substitution. Nevertheless, juvenile sharpsnout sea bream fed with $30 \%$ of CP provided by SFM had normal growth without showing any statistical difference among treatments. The difference in weight gain and FCR between D. puntazzo (ranging from 1.85 to 1.98 ) and S. aurata (fluctuating from 1.69 to 2.59 ) could be attributed to the ability of $D$. puntazzo to feed on the bottom of the tank, feeding behaviour that obviously does not occur in cages (Karakatsouli et al., 2006), and even though in our case the fish were in cages, perhaps if these fish were in tanks they would achieve better growth and feed efficiency.

Biometric parameters measured in sharpsnout sea bream demonstrated that different SFM inclusion levels did not affect any value reported. On the contrary, Hernández et al. (2007) obtained inversely proportional results in hepatosomatic index and a slight reduction in mesenteric fat index while plant meal substitution increased.

The significant differences found among dietary groups in terms of moisture content and crude lipid differed from data reported by Hernández et al. (2007) and Sanchez-Lozano et al. (2007), who did not obtain statistical differences in any of the parameters analysed. Crude protein efficiency (CPE) and gross energy efficiency (GEE) results differed from those reported by Sanchez-Lozano et al. (2007) probably due to sharpsnout sea bream feeding habits, and similar results were reported by Furuya et al. (2000). On the other hand, Gill et al. (2006) concluded that with up to $20 \%$ of SFM substitution there was no adverse effect on CPE in Atlantic salmon.

Fish in the present study grew without showing any apparent pathological disease that could be caused by nutrient deficiency or levels of indigestible carbohydrates originating from the hulls (cell wall matrix, e.g. cellulose, hemicellulose and lignin) and non-starch polysaccharides (Van Soest et al., 1991; Francis et al,, 2001), as shown in the biometric analysis.

The only statistical differences in the body composition of fish fed with the different SFM substitutions were in valine, leucine and aspartate, with a positive increase, and, as Saavedra et al. (2007) indicated, the EAA profile in the fish carcass has been widely used as a good indicator of amino acid requirements of fish. Thus the $D$. puntazzo amino acid profile in the different treatments at the end of the trial implied a balance of amino acid values in the experimental diets.

Tryptophan (Trp) was not possible to analyse in the raw material, or experimental diets or body composition, but according to Guillaume et al. (2004) this EAA is present in fish meal in approximately 0.52$0.75 \mathrm{mg} \mathrm{kg}^{-1}$. Fontaine et al, (2001) indicated that Trp content in SFM ranged from 0.34 to $0.59 \%$ and as the experimental diets only had $30 \%$ maximum replacement of $\mathrm{CP}$ by SFM, the differences in Trp levels were likely small.

In amino acid retentions there were no statistical differences among treatments as a result of balance in amino acid composition of the experimental diets. The same conclusion as proposed by Aragão et al. (2004), who affirmed that when dietary amino acid profile is balanced through supplementation, an increase in amino acid retention is probably reflected in an increase in protein retention. Another important reason for these results seemed to be that in nature, vegetable protein is a part of $D$. puntazzo's diet (Mena Sellés and García García, 2002).

Moreover, hepatocyte morphology seemed not to be altered by vegetal substitution, similar to hepatic cell quantification, although a reduction in number of hepatocytes in the 10 and $20 \%$ dietary treatments was observed, perhaps due to slight hypertrophy caused by an accumulation of glycogen, similar to results reported by Pereira et al. (2002) in rainbow trout fed diets with a partial substitution of Brassica by-products. Likewise, Hansen et al. (2006) indicated no histopathology in livers of cod fed a mixture of soy protein concentrate and wheat gluten with a maximum inclusion of $440 \mathrm{~g} \mathrm{~kg}^{-1}$. It should be noted that histological analysis shows that this species presents a hepatopancreas instead of two separate organs.

In gut histology as described previously, it seemed that SFM substitution did not alter fish morphology, except perhaps for a slight elongation of villi, especially in the PI portion, possibly due to the increment of crude fibre (7.4\%) and reduction in carbohydrate in the higher substitution diets, with similar results reported by Aslaksen et al. (2007). However, Baeverfjord and Krogdahl (1996) and Uran et al. (2009), reported enteritis in Atlantic salmon fed a diet based on partial replacement of fish meal by soybean meal. Uran et al. (2008) also reported enteritis in common carp, attributing this alteration to soya saponins that induced inflammation and monocyte proliferation, although Uran et al. (2009) indicated that this affect could fluctuate according to the soybean meal source.

On the other hand, Goblet cells are associated with the immune system through the production of mucus which acts as a lubricant in the alimentary tract and provides protection against chemical and mechanical damage (Marchetti et al., 2006). Thus, this aspect could be considered an alteration of mucosa folds of the mid - and distal portions, especially in the $10 \%$ and $30 \%$ treatment groups, possibly due to different factors, such as fibre content. Other possible factors may be the presence of a polyphenolic compound that could cause a reaction in mucosa folds, or the higher amount of arginine $\left(3.74 \mathrm{~g} 100^{-1} \mathrm{~g}\right)$ and

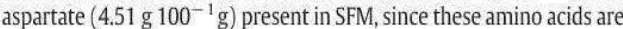
known to improve insulin secretion and growth hormone as well as increase the production of lymphocytes and the regulation of cytokine production that has immunostimulatory effects (Li et al., 2007).

These authors also indicated that an adequate dietary provision of all amino acids is necessary to sustain normal immunocompetence and protect the host from a variety of diseases in all species. The results of this study showed that in sharpsnout sea bream, amino acid composition of the experimental diets was well balanced and retention was good.

\section{Acknowledgements}

This research was supported by grants from the 'Planes Nacionales de Acuicultura (JACUMAR)' in Spain.

\section{References}

A.0.A.C. (Association of official Analytical Chemists, 1990. Official Methods of Analysis, 15th ed. Association of Official Analytical Chemists, Arlington, VA, USA. 1298 pp. ragão, C., Conceição, L.E.C., Martins, D., Ronnestad, L., Gomes, E., Dinis, M.T., 2004. A balance dietary amino acids profile improves amino acids retention in post-larval Senegalense Sole (Solea senegalensis). Aquaculture 233, 293-304.

Aslaksen, M.A., Kraugerud, O.F., Penn, M., Svihus, B., Denstadli, V., Jorgensen, H.Y Hillestad, M., Krogdahl, A., Storebakken, T., 2007. Screening of nutrient digestibilities and intestinal pathologies in Atlantic salmon, Salmo salar, fed diets with legumes oil seeds or cereals. Aquaculture 272, 541-555.

Baeverfjord, G. Krogdahl, A., 1996. Development and regression of soybean meal induced enteritis in Atantic salm Dolmo saler L distal intestine: a can mea with the intestines of fasten fish. J Fish Dis 19, 375-387. 
Bakke-McKellep, A.M., Koppang, E.A., Gunnes, G., Sanden, M., Hemre, G.-l., Landsverk, T., Krogdahl, A., 2007. Histological, digestive, metabolic, hormonal and some modified soybeans. Fish Dis $30,65-79$.

Bosch, L, Alegria, A., Farré, R., 2006. Application of the 6-aminoquinolyl-N-hydroxysuccinimidyl carbamate (AOC), reagent to the RP-HPIC determination of amino acids in infant foods. J. Chromatogr. B: Anal. Technology Biomedical Life Science 831, 176-183 www.elservier.com/locate/chromb,

Chatzifotis, S., Estaban, A.G., Divanach, P.. 2006. Fishmeal replacement by alfalfa protein concentrate in sharpsnout sea bream Diplodus puntazzo. Fish. Sci. 72, 1313-1315. Cenovese, L., Palme dietary ingredient in practical diets for blackspot seabream Pagellus bogaraveo: a histological and enzymatic investigation. J. Fish Biol. 74, 773-789.

avarolo, E, Lopiano, L, Mazzola, A., 2002. Short Communication. Rearing sharpnout sea bream (Diplodus puntazzo Cetti 1777) in a Mediterranean fish farm monoculture versus policulture. Aquac, Res. 33, 137-14

ontaine, J., Hörr, J., Schirmer, B., 2001. Near-infrared reflectance spectroscopy enables the fast and accurate prediction of the essential amino acid contents in soy rapeseed meal, sunflower meal, pe

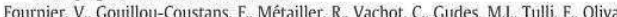
Teles, A, Tibaldi, E Kau, SJ, 2002 . Protein and a Teles, A., Tibaldi, E., Kaushik, S.J., 2002. Protein and arginine requirements for maintenance and nitrogen gain in four teleosts. Br. J. Nutr, 87, 459-469, alternate fish ingredients and their effects in fish. Aquaculture 199, 197-227.
a

Furuya, V.R.B., Furaya, W.M., Hayshi, C., Soares, C.M., 2000. Niveles de inclusión de harina de girasol en la alimentación de la tilapia

etapa juvenil. Zootecnia Trop. 18 (1), 1-10,
García Gómez, A., Ortega Ros, A., 1993, Revisión general del cultivo de nuevas especies piscicola en el area mediterranea y experiencias realizadas en el Centro Oceanografico de Murcia. Informes Técnicos Instituto Español de Oceanografía 141, 1-32.

Gill, N., Higgs, D.A., Skura, B.J, Rowshandeli, M., Dosanjh, S., Mann, J., Gannam, A.L. 2006. Nutritive value of partially dehulled and extruded sunflower meal for postsmolt Atlantic Salmon (Salmo salar L) in sea water. Aquac. Res. 37, 1348-1359.

Guillaume, J., Kaushik, S., Bergot, P., Métailler, R. (Eds.), 2004. Nutrición y alimentación de peces y crustáceos. Ediciones Mundi-prensa, Madrid - España. $475 \mathrm{pp}$.

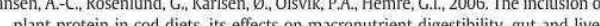
plant protein in cod diets, its effects on macronutrient digestibility, gut and live

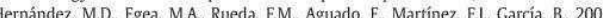

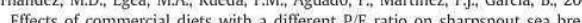
Effects of commercial diets with a different $\mathrm{P} / \mathrm{E}$ ratio on sharpsnout sea bream
(Diplodus puntazzo) growth and nutrient utilisation. Aquaculture 195, 321-329. Hernández, M.D., Martínez, F.J. Jover, M. García, B. 2007. Effects of partial replacement of fish meal by soybean meal in sharpsnout seabream (Diplodus puntazzo) diet. Aquaculture 263, 159-167.

arakatsouli, N. Ppafotiou, P., Papoutsoglou, S.E., 2006. Mono and duo culture of juvenile sharpsnout sea bream Diplodus puntazzo (Cetti) and Gilthead seabrean Sparus aurata L, in a recirculated water system. Aquac, Res. 37, 1654-1661.

Li, P., Yin, Y.L, Li, D., Kim, S.W.. Wu, G., 2007. Amino acids and immune function. Br. J. Nutr. $98,237-252$

Lundstedt, L.M., 2004. Adaptative histological variations in the gut of pintado Pseudoplatystoma corruscans) fed different protein levels. Aquaculture Congress San Paolo Brazil, pp. 33-44.
Marchetti, L., Capacchietti, M., Sabbieti, M.G., Accili, D., Materazzi, G., Menghi, G., 2006 Histology and carbohydrate histochemistry of the alimentary canal in the rainbow Histology and carbohydrate histochemistry of the alime
trout Oncorhynchus mykiss. J. Fish Biol, 68, 1808-1821.

Martínez, C.A., 1984. Advances in the substitution of fish meal and soybean meal by sunflower meal in diets of raingow trout (Salmo Gairdneri L) An Inst. Cienc My Limnol. Univ. Nac. Auton. Méx. 13 (2), 345-350.

McFadzen, I.R.B., Coombs, S.H., Halliday, N.C., 1997. Histological indices of the nutritional condition of sardine, Sardina pilchardus (Walbaum) larvae off the north coast of Spain. J. Exp. Mar. Biol, Ecol. 212, 239-258.

Mena Sellés, C., García García, B., 2002. Importancia de la proteína vegetal en la dieta hatural de poblaciones salvajes de Sargo picudo Diplodus puntazzo Sus implicaciones en el cultivo intensivo. Revista AquaTIC $\mathrm{N}^{\circ}$ 17. www. revistaaquatic.com/swusyiv/hyml/sty1705/sargo,htm.

Olvera-Novoa, M., Olivera-Castillo, L, Martínez-Palacios, C.A., 2002. Sunflower seed meal as a protein source in diet for Tilapia rendalli (Boulanger, 1986) fingerlings, Aquac, Res, 33, 223-22.

Orban, E., Di Lena, G., Ricelli, A., Paletti, F., Casini, L., Gabelli, L., Caproni, R., 2000. Quality characteristics of sharpsnout sea bream (Diplodus puntazzo) from different intensive rearing systems. Aquaculture $70,27-32$,

Krogdahl. A., Skrede, A., 2009. Pe protein concentrate substituting fish meal or soybean meal in diets for Atlantic salmon (Salmo salar) - effect on growth performance, nutrient digestibility, carcass

Pereira, O, Rosa, E., Pires, M.A., Fontainhas-Fernandes, A., 2002. Brassica by-products in diets of ranbow trout (Oncorhynchus mykiss) and their effects on performance, body compositon, thyroid status and liver histology. Anim. Feed Sci. Technol. 101, 171-182. Effects of fishmeal replacement with soybean meal as protein source, and protein replacement with carbohydrates as an alternative energy source on sharpsnout sea bream, Diplodus puntazzo, fatty acid profile. Aquac. Res. 53, 1220-1227.

Saavedra, M., Beltran, M., Pousão-Ferreira, P., Dinis, M.T., Blasco, J., Conceição, LE.C 2007. Evaluation of bioavailability of individual amino actds in Diplodus puntazzo larvae: towards the ideal dietary amino acid profile. Aquaculture 263, 192-198. Sala, E., Ballesteros, E., 1997. Partioning of space and food resources by three fish of the genus Diplodus (Sparidae) in a Mediterranean rocky infralitoral ecosystem. Mar. Ecol. Prog. Ser. 152, 273-28

Sanchez-Lozano, N.B., Tomás-Vidal, A., Martínez-Llorens, S., Nogales-Mérida, S., Espert, Jrean (Sparus aurata L.) fed sunflower meal. Aquaculture 272, 528-534

Sandeam (Sparus aurata L.) fed sunflower meal. Aquaculture 272, 528-534. 2005 An examination of the intestinal tract of Atlantic salmon, Salmo salar $L_{\text {, }}$ parr fed different varieties of soy and maize.J Fish Dis 28, 317-330.

Snedecor, G., Cochran, W., 1971. Statistical Methods. The lowas State University Press, Ames, lowa, USA. 592 pp.

Uran, P.A., Goncalves, A.A., Taverne-Thiele,J.J. Schrama, J.W. Verreth. J.A.J. Rombout, J.H.W.M., 2008. Soybean meal induces intestinal inflammation in common carp (Cyprimus carpio L.). Fish Shellfish Immunol 25, 751-760.

Uran, P.A., Scrama, J.W., Jaafari, S., Baardsen, G., Rombout, J.H.W.M., Koppe, W., Verrth, J.A.J 2009. Variation in commercial sources of soybean meal influences the severity of enteritis in Atlantic salmon (Salmo salar L). Aquac. Nutr. 15, 492-499.

Van Soest, P.J., Robertson, J.B., Lewis, B.A., 1991. Symposium: carbohydrate methodology, metabolism, and nutritional implications in dairy cattle; methods for dietary fibre, neutral detergent fibre, and no starch polysaccharides in relation to anima nutrition. J. Dairy Sci. 74, 3583-3597. 



\section{CAPÍTULO 5}

Sharpsnout sea bream (Diplodus puntazzo) growth and health status altered by Pea

Protein Concentrate.

Enviado a: Aquaculture Research. 



\title{
SHARPSNOUT SEA BREAM (Diplodus puntazzo) GROWTH AND HEALTH STATUS ALTERED BY PEA PROTEIN CONCENTRATE.
}

\author{
Silvia Nogales Mérida, Ana Tomás-Vidal, Silvia Martínez-Llorens, Javier Moya \& Miguel Jover \\ Cerdá. \\ ${ }^{1}$ Aquatic Resources Research Group. Animal Science Institute. Polytechnic University of Valencia.
}

Correspondence: Silvia Nogales-Mérida, Polytechnic University of Valencia. Camino de Vera, 14. 46071- Valencia (Spain). silvianogales@hotmail.com. Tel: 34-96-3877434; Fax 34-96-3877439

\begin{abstract}
Four diets were formulated for replacing $0,16,32$ and $48.7 \%$ of fish meal by pea protein concentrate (PPC) supplemented with methionine $\left(0,1,3\right.$ and $\left.4 \mathrm{~g} \mathrm{~kg}^{-1}\right)$. These diets were prepared to feed sharpsnout sea bream juveniles $(14 \mathrm{~g})$. Each diet was tested by triplicate. Experimental diets were isoproteic $(43 \% \mathrm{CP})$ and isolipidic $(19 \% \mathrm{CL})$ and fish were fed to satiation twice a day. After 125 days, fish growth was affected by treatment. Feed efficiency did not present significant differences in any treatment. In biometric parameters, there was a gradual and significant reduction in hepatosomatic index. Neither corporal analyses nor retention were affected by PPC inclusion. Essential amino acids (EAA) retention did not present any statistical differences among treatments. Apparently fish liver did not exhibit alteration, although, there was observed a reduction in hepatocytes quantity per area. Besides, fish intestine presented a gradual increment in length and goblet cells in middle intestine and posterior intestine and a reduction of these cells in anterior intestine. The lamina propria also increased in the anterior intestine. All these alteration shown that PPC, still contained antinutritional substances that affect the gastrointestinal tract and therefore reduce fish growth.
\end{abstract}

Keywords: Amino acid retention; Diplodus puntazzo; Pea protein concentrate; Liver; Intestine; Histology.

\section{Introduction}

Sharsnout sea bream (Diplodus puntazzo) is one of the alternative species to amplify fish offer in Mediterranean aquaculture, its production and commercialization is rising in Italy and Greek. But most of this production has been based mainly on fishmeal and a partial inclusion of soybean meal as protein sources. According to Rana, Siriwardena and Hasan (2009) the prices of these meals have been rising more than $260 \%$ in the last decade, causing a rise prices in commercial pellets. Besides, one of the most common Mediterranean fish, gilthead sea bream has decreased its production, due to low market prices. In the last years a few research works with soybean meal as substitute to fishmeal in sharpsnout sea bream (Rondán, Hernández, Egea, García, Jover, Rueda \& Martínez 2004; Hernandez, Martínez, Jover \& García García 2007) have been done. Other vegetable meals have also been assayed to feed sharpsnout sea bream, such as alfalfa protein concentrate (APC) (Chatzifotis, Esteban \& Divanach 2006) and 
sunflower meal (SFM) (Nogales-Mérida, Tomás-Vidal, Martínez-Llorens \& Jover Cerdá 2009), but with low level inclusion.

In the last decade pea protein concentrate (PPC) has been considered an alternative source to replace not only fishmeal but also soybean meal thanks to the high protein content $(42-70 \% \mathrm{CP})$, a similar amino acids profile to soybean meal (Booth, Allan, Frances \& Parkinson 2001; Øverland, Sørensen, Storebakken, Penn, Krogdahl \& Skrede 2009), lack of anti-nutritional factors, good binding properties and good palatability.

It has been proved in some marine species, such as Sparus aurata (SánchezLozano, Martínez-Llorens, Tomás-Vidal \& Jover Cerdá 2010); Oncorhynchus mykiss (Thiessen, Campbell \& Tyler 2003) and Salmo salar (Carter \& Hauler 2000; Øverland et al. 2009; Penn, Bendiksen, Campbell \& Krogdahl 2011), with good results in growth up to $200 \mathrm{~g} \mathrm{~kg}^{-1}$. Besides, Schulz, Wickert, Kijora, Ogunki and Rennert (2007) essayed in Oreochromis niloticus with good results in growth and feed efficiency parameters with up to $149 \mathrm{~g} \mathrm{~kg}^{-1}$ of PPC inclusion.

In spice of the apparent beneficial properties indicated above, Shulz et al. (2007) indicated that PPC produced by air-classified, dry process of fine grinding of dehulled peas presented increased levels on antinutritional factors like protease inhibitors, phytic acid and $\alpha$-galactosides, that is not the case of PPC obtained by wet processing methods that include acidic washing or thermal processing produces a protein with lower levels of antinutritional ingredients. Besides, Frackek, Kostyra, Kostyra and Krawczuk (2007), indicated that pea proteins, like globulins, albumins and insolubles, are the potential allergens for humans and animal.

Furthermore there are some researches on alternative meals and their effects on fish gut and liver, especially soybean meal (Grisdale-Helland, Helland, Baeverfjord \& Berge 2002; Krogdahl, Bakke-McKellep \& Baeverfjord 2003; Catacutan \& Pagador 2004; Marcouli, Alexis, Andriopoulou \& Iliopoulou-Georgudaki 2004; Evans, Pasnik, Peres, Lim \& Klesius 2005; Bonaldo, Roem, Pecchini, Grilli \& Gatta 2006; Bonaldo, Roem, Faagioli, Pecchini, Cipollini \& Gatta 2008; Urán, Gonçalves, TAverne-Thiele, Schrama, Verreth \& Rombout 2008; Urán, Schrama, Jaafari, Baardsen, Rombout, Koppe \& Verreth 2009), some in pea meal (Sitjà-Bobadilla, Peña-Llopis, GómezRequeni, Médale, Kaushik, \& Pérez-Sánchez 2005) or pea protein concentrate (Overland et al. 2009; Penn et al. 2011 among others). Most of them reported alteration in gut and liver caused by antinutritional factors or amino acids deficiency present in alternative vegetable meals. In sharpsnout sea bream only, Nogales-Mérida et al. (2010) studied how sunflower meal affected gut and liver morphology. Considering all this facts the purpose of this study was to determinate the effect of PPC incorporation in experimental diets and on performance, gut histology and amino acids retention of sharpsnout sea bream.

\section{Material and Methods}

\subsection{Experimental conditions, fish and feeding regime}

The experiment was carried out at the Aquaculture laboratory of the Animal Science Technological Institute of Polytechnic University of Valencia, (Valencia, Spain). D. 
puntazzo juveniles were brought from an Italian commercial hatchery and acclimatised to laboratory conditions for eight weeks. They were fed with a standard commercial diet, Microbaq 10 (48\% Crude Protein; 23\% Crude Lipid; 11\% Ash; 2.2\% Crude Fibre and 14\% Nitrogen Free Extract) (Dibaq-Diproteg, S.A. Segovia, Spain).

Four cylindrical fibreglass $(750 \mathrm{~L})$ tanks were used to set up in a recirculating marine water system $\left(30 \mathrm{~m}^{3}\right.$ capacity). All the tanks were equipped with aeration and water was heated by a heat pump installed in the system. Throughout the experiment period, the temperature fluctuated from $18.6^{\circ} \mathrm{C}$ through $26.4^{\circ} \mathrm{C}$ with an average temperature of $22.2 \pm 2^{\circ} \mathrm{C}$; the dissolved oxygen was $6.3 \pm 0.4 \mathrm{mg} \mathrm{L}^{-1}$. The pH was 7.4 \pm 1.0 . $\mathrm{NH}_{4}^{+}$value was $0.02 \pm 0.1 \mathrm{mg} \mathrm{L}^{-1}$. $\mathrm{NO}_{2}^{-}$was $0.1 \pm 0.06$ and the salinity was $31 \pm 5$. Photoperiod was natural and all tanks had similar light conditions.

From the initial pool, 216 fish were collected with an initial average weight of $14 \mathrm{~g}$ and distributed into 12 basket with a capacity of $98 \mathrm{~L}$ (18 fish per basket). Triplicate groups of fish were fed by hand (at 09:00 and 16:00 h) to satiety for 125 days (from February 20 to June 25) in two separate meals 6 days per week. At the beginning and end of the experiment, fish were weighed individually, but in the middle of the experiment they were weighed in groups of two or three every three weeks after fasting for $24 \mathrm{~h}$ and anaesthesia with clove oil containing $87 \%$ of eugenol (Guinama ${ }^{\circledR}$, Valencia, Spain).

At the outset 10 fish were collected for initial corporal analysis and at the end of the experiment five fish per tank were removed to determinate biometric parameters and stored at $-30{ }^{\circ} \mathrm{C}$ for whole body composition. Besides, three fish per tank were collected for histology analysis. Their guts and liver were removed and kept in formaldehyde $10 \% \mathrm{v} / \mathrm{v}$.

\subsection{Experimental diets}

Composition of experimental diets is shown in Table 1. Four approximately isonitrogenous (450 $\mathrm{g} \mathrm{kg}^{-1}$ crude protein CP) and isolipidic diets (200 $\mathrm{g} \mathrm{kg}^{-1}$ crude lipid CL) were formulated including PPC in substitution of fishmeal at levels of $0,162,325$, and $487 \mathrm{~g} \mathrm{~kg}^{-1}(0,16,32$ and 48 respectively), supplemented with methionine $(0,1,3$ and $4 \mathrm{~g} \mathrm{~kg}^{-1}$ ) (Table 1), but final proximate composition ranged among $424-435 \mathrm{~g} \mathrm{~kg}^{-1}$ in CP and $188-192 \mathrm{~g} \mathrm{~kg}^{-1}$ in CL. The PPC inclusion level was calculated for substituting 0,20, 40 and $60 \%$ of protein from fish meal. Additionally, soybean oil was included at $51 \mathrm{~g} \mathrm{~kg}^{-1}$ in all diets following results obtained in previous trial (Piedecausa, Mazón, García García \& Hernández 2007). Amino acids in diets and raw material are shown in table II. Diets were prepared by cooking-extrusion processing with a semiindustrial twin-screw extruder (CLEXTRAL BC-45, Firmity, St. Etienne, France). Processing conditions were as follows: $100 \mathrm{rpm}$ speed screw, $110^{\circ} \mathrm{C}$ of temperature and $30-40 \mathrm{~atm}$ pressure and 1 and $2 \mathrm{~mm}$ diameter pellets, according to fish size.

\section{Biometric analysis}

At the end of the experimental period, three animals from each basket were sacrificed to collect data on fish length, total weight and liver and mesenteric fat weights. These data were used to calculate the condition factor (CF), hepatosomatic index, (HSI), intestinal somatic index (ISI), mesenteric fat (MF) and dress out percentage (DP). All these 
values were calculated according to the following formulas: $\mathrm{CF}=$ [body weight $(\mathrm{g}) /$ total length $\left.(\mathrm{cm})^{3}\right] \times 100$. HSI $=[$ liver weight $(\mathrm{g}) /$ body weight $(\mathrm{g})] \times 100 . \mathrm{MF}=$ [mesenteric fat weight $(\mathrm{g}) /$ body weight $(\mathrm{g})] \times 100$. ISI $=[$ intestine weight $(\mathrm{g}) /$ body weight $(\mathrm{g})] \times 100$. VSI $=[$ visceral weight $(\mathrm{g}) /$ fish weight $(\mathrm{g})] \times 100 . \mathrm{DP}=[$ total fish weight $(\mathrm{g})$ - visceral weight $(\mathrm{g})$-head weight $(\mathrm{g})] /$ fish weight $(\mathrm{g})] \mathrm{x} 100$. Crude protein efficiency, CPE $(\%)=($ Increment of protein corporally $(\mathrm{g})) \times 100 /$ (ingestion protein, $(\mathrm{g}))$. Grow energy efficiency, GEE $(\%)=(\%)$ (Increment of energy corporally, $(\mathrm{kJ})) \times 100 /$ (ingestion de energy $(\mathrm{kJ})$ )

Table 1. Ingredients and proximate composition of experimental diets

\begin{tabular}{|c|c|c|c|c|}
\hline Ingredients $\left(\mathrm{g} \mathrm{kg}^{-1}\right)$ & 0 & 16 & 32 & 48 \\
\hline Fish meal, herring (5-02-000) & 550 & 442 & 333 & 225 \\
\hline Pea protein meal & 0 & 162 & 325 & 487 \\
\hline Wheat (4-05-268) & 239 & 180 & 120 & 61 \\
\hline Fish oil (7-08-048) & 100 & 104 & 108 & 112 \\
\hline Soybean oil & 51 & 51 & 51 & 51 \\
\hline Maltodextrin & 50 & 50 & 50 & 50 \\
\hline Vitamin mix $^{a}$ & 6.3 & 6.3 & 6.3 & 6.3 \\
\hline Mineral mix $^{\mathrm{b}}$ & 2.2 & 2.2 & 2.2 & 2.2 \\
\hline Vitamin C & 1.5 & 1.5 & 1.5 & 1.5 \\
\hline Methionine $e^{c}$ & 0 & 1 & 3 & 4 \\
\hline \multicolumn{5}{|c|}{ Proximate composition ( $\mathrm{g} \mathrm{kg}^{-1}$ dry matter) } \\
\hline Dry Matter (DM) & 919.9 & 924.0 & 927.9 & 927.9 \\
\hline Crude protein $(\mathrm{CP})$ & 424.5 & 426.8 & 431.8 & 435.6 \\
\hline Crude lipid (CL) & 188.0 & 190.0 & 192.6 & 187.0 \\
\hline Ash & 100. & 89.8 & 79.6 & 70.4 \\
\hline Crude fibre (CF) & 4.8 & 5.2 & 7.1 & 11.6 \\
\hline \multicolumn{5}{|l|}{ Calculated values } \\
\hline $\mathrm{N}$-free extract $(\% \mathrm{NFE})^{\mathrm{d}}$ & 282.7 & 288.2 & 288.9 & 295.4 \\
\hline $\mathrm{CPD}\left(\mathrm{g} 100 \mathrm{~g}^{-1}\right)^{\mathrm{e}}$ & 366.9 & 377.8 & 379.9 & 384.5 \\
\hline $\mathrm{GE}\left(\mathrm{MJ} \mathrm{kg}^{-1}\right)^{\mathrm{f}}$ & 22.6 & 22.9 & 23.1 & 23.1 \\
\hline $\mathrm{CP} / \mathrm{GE}\left(\mathrm{g} \mathrm{MJ}^{-1}\right)^{\mathrm{f}}$ & 18.8 & 18.6 & 18.7 & 18.9 \\
\hline \multicolumn{5}{|c|}{ 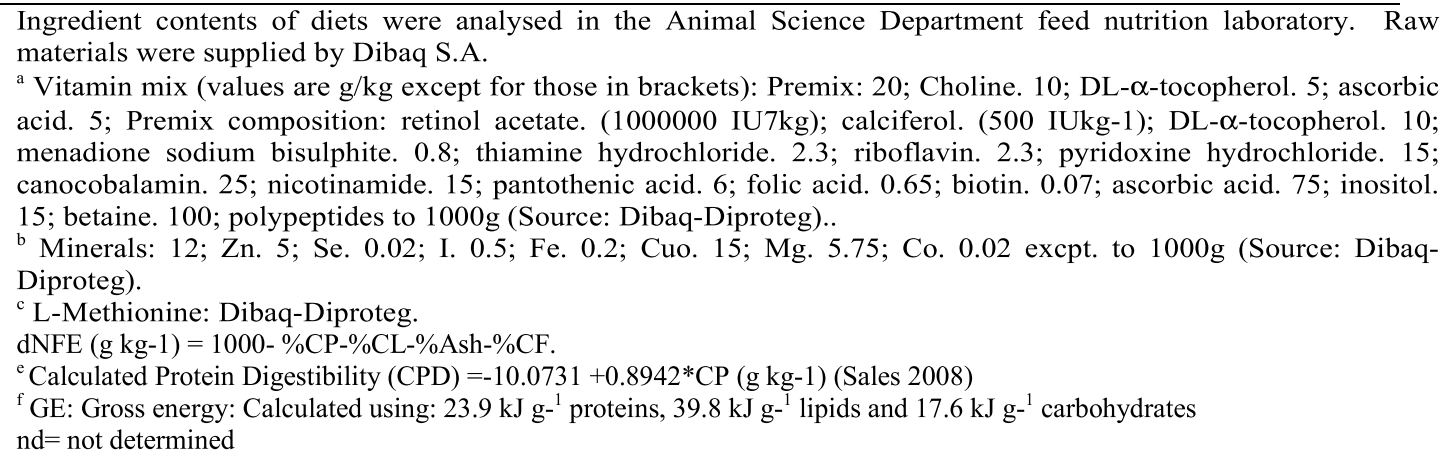 } \\
\hline
\end{tabular}

\subsection{Chemical analysis}

Dietary ingredients, diets and fish composition were analysed by the Association of Official Analytical Chemists AOAC (1990) procedures; dry matter after drying in an 
oven at $105^{\circ} \mathrm{C}$ until constant weight; ash by incineration in a muffle furnace at $550{ }^{\circ} \mathrm{C}$ for $5 \mathrm{~h}$; crude protein $(\mathrm{N} \times$ 6.25) by the Kjeldahl method after acid digestion (Kjeltec 2300 Auto Analyser, Tecator Höganas, Sweden); crude lipid was extracted using diethyl ether extraction in a Soxhlet 1043 extraction unit, Tecator. Crude fibre analyses of raw materials and diets were performed following the Ankom system (Fibertec System M., 1020 Hot Extractor, Tecator).

Amino acid analyses (hydrolysis and performic acid oxidation) of raw material, diets and body fish were done following Bosch, Alegria and Farré (2006), methodology, but with a slight modification. Approximately $100 \mathrm{~g}$ of crude protein was used to determine the amino acid values not only for experimental diets and raw material, but also for fish body analysis instead of $25 \mathrm{~g}$ of crude protein as the authors suggested. To determine the amino acids retention, the following formula was used:

AA Retention $(\%)=($ Increment of Amino acids corporally g) x $100 /$ (ingestion of protein $g$ )

\section{Histological methodology}

The gastrointestinal tracts collected were divided into three parts: 1) Anterior intestine (AI), 2) Mid intestine (MI), 3) Posterior intestine (PI). Tissue samples were fixed in phosphate buffered formalin $(4 \% \mathrm{pH} 7.4)$ and then transferred to $70 \%$ ethanol for storage until processing. All formalin fixed tissues were routinely dehydrated in ethanol, equilibrated in Ultraclear ${ }^{\mathrm{TM}}$ and embedded in paraffin according to standard histological techniques. Eighteen longitudinal sections (approximately $5 \mu \mathrm{m}$ thick) of anterior, mid and posterior intestines per treatment were cut and stained with haematoxylin and eosin (HE). Processing of the tissues took place at the Histology section of the Animal Science Department of the Polytechnic University of Valencia (Spain). Blinded histological examination was performed by light microscopy (Nikon Phase Contrast 0.90 Dry JAPAN). Tissue morphology was assessed according to Baeverfjord and Krogdahl (1996) as well as Lundstedt's (2004) methodology, but in liver morphology evaluation the McFadzen, Coombs and Halliday (1997) criteria were used, in addition to quantification of hepatocytes, to observe possible alterations revealed through differences in the hepatocyte condition or hepatic cell morphology.

In liver, hepatocytes and acinar cell degeneration status were evaluated. In intestine, the villous length, villous width, lamina propria width, muscular thickness and number of goblet cells per area $\left(125.000 \mu \mathrm{m}^{2}\right)$ were measured in $\mu \mathrm{m}$.

\subsection{Statistical analysis}

Growth data and nutritive parameters were treated using multifactor analysis of variance (ANOVA), introducing the initial live weight as covariate (Snedecor \& Cochran 1971). Newman-Keuls test was used to assess specific differences among diets at significance levels of $\mathrm{P}<0.05$ (Statgraphics, Statistical Graphics System, Version Plus 5.1, Herndon, Virginia, USA).

The number of hepatocytes was quantified per area $\left(125.000 \mu \mathrm{m}^{2}\right)$ at the same time as the length and width of the mucosa fold, and the numbers of mucus cells were analysed with a simple ANOVA. Histological analysis of hepatocytes and acinar cells 
was performed using the McFadzen et al. (1997) methodology and evaluated by a Cross Tabulation and Chi Square contrast $\left(\mathrm{X}^{2}\right)$ on Statgraphics.

\section{Results}

The experimental diets showed that some amino acids exhibited a tendency to increment as PPC inclusion increase, although histidine, methionine, threonine, alanine, glycine, proline and tyrosine content diminished while PPC inclusion increase, besides the relation between EAA and NEAA showed a tendency to increase as the PPC inclusion augmented $(0.89,0.91,0.94$ and 0.96 respectively) Table 2.

Table 2. Amino acid content of ingredients and experimental diets expressed on a dry matter (DM) basis.

\begin{tabular}{|c|c|c|c|c|c|c|}
\hline & FM & PPC & $\mathbf{0}$ & 16 & 32 & 48 \\
\hline \multicolumn{7}{|c|}{ Essential amino acid content calculated as: $\mathrm{g} \mathrm{kg}^{-1}$} \\
\hline Arginine & 61.8 & 67.1 & 35.04 & 38.98 & 42.91 & 46.85 \\
\hline Histidine & 26.6 & 15.6 & 15.22 & 14.73 & 14.22 & 13.73 \\
\hline Isoleucine & 35.4 & 25.6 & 20.35 & 20.46 & 20.55 & 20.66 \\
\hline Leucine & 56.6 & 46.3 & 32.72 & 33.72 & 34.70 & 35.69 \\
\hline Lysine & 44.3 & 38.8 & 25.12 & 26.44 & 27.74 & 29.06 \\
\hline Methionine & 16.3 & 5.5 & 9.21 & 8.28 & 7.34 & 6.41 \\
\hline Phenylalanine & 49.3 & 37.6 & 28.34 & 28.80 & 29.25 & 29.72 \\
\hline Threonine & 36.0 & 23.4 & 20.55 & 20.27 & 19.97 & 19.69 \\
\hline Valine & 38.6 & 28.2 & 22.31 & 22.45 & 22.56 & 22.69 \\
\hline \multicolumn{7}{|c|}{ Non-essential amino acid content calculated as: $\mathrm{g} \mathrm{kg}-\mathrm{I}$} \\
\hline Alanine & 44.5 & 24.1 & 25.41 & 24.27 & 23.12 & 21.99 \\
\hline Aspartate & 63.3 & 57.6 & 36.12 & 38.30 & 40.46 & 42.63 \\
\hline Cystine & 10.1 & 11.0 & 6.21 & 6.74 & 7.27 & 7.80 \\
\hline Glutamine & 89.9 & 95.0 & 56.53 & 60.46 & 64.37 & 68.30 \\
\hline Glycine & 53.6 & 25.3 & 30.58 & 28.62 & 26.63 & 24.66 \\
\hline Proline & 70.6 & 25.1 & 41.50 & 37.28 & 33.01 & 28.79 \\
\hline Serine & 29.8 & 28.7 & 17.55 & 18.70 & 19.84 & 20.98 \\
\hline Tyrosine & 36.0 & 23.2 & 20.12 & 19.91 & 19.69 & 19.48 \\
\hline $\mathrm{EAA} / \mathrm{NEAA}^{\mathrm{c}}$ & 0.92 & 0.99 & 0.89 & 0.91 & 0.94 & 0.96 \\
\hline
\end{tabular}

Fish survival rate at the end of the trial was over $91 \%$ in all dietary groups. This percentage was due to fish that escaped from their cage not to fish death.

Final fish growth at the end of the trial was affected by PPC inclusion. Fish growth was diminishing while PPC inclusion increased. Similar values were observed in SGR and TCG. Sharpsnout sea bream fed $48 \%$ of PPC inclusion obtained the lowest 
value. Feed efficiency parameters were not affected by PPC inclusion, although, fish fed $32 \%$ PPC presented the highest value in FIR and FCR and the lowest value in PER $(2.11,1.90$ and 1.31 respectively) (Table 3$)$.

In figure 1 it is observed a comparison among TGC values obtained by different researchers. Only sharpsnout sea bream fed with sunflower meal $\left(352 \mathrm{~g} \mathrm{~kg}^{-1}\right)$ and gilthead sea bream fed up to $325 \mathrm{~g} \mathrm{~kg}^{-1}$ obtained higher values than D. puntazzo fed with PPC inclusion.

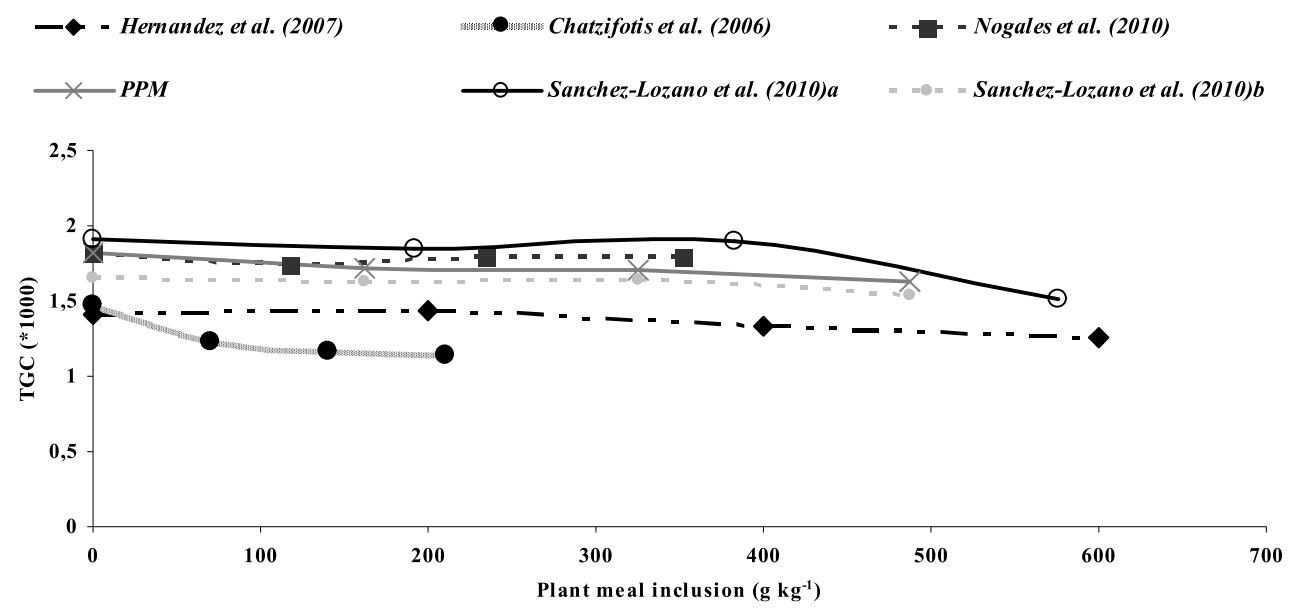

Figure 1. Results of sharpsnout sea bream growth fed with different plant ingredients obtained by some authors (alfalfa concentrate by Chatzifotis et al. 2006; soybean meal by Hernández et al. 2007 and sunflower meal by Nogales-Mérida et al. 2010) and also comparing with gilthead sea bream growth (mixture of rice and pea protein concentrates by Sánchez-Lozano et 2010a and pea protein concentrate by Sánchez-Lozano et al. 2010b).

Thermal Growth Coefficient TGC* $1000=1000 *\left[\mathrm{Fw}^{1 / 3}-\mathrm{Iw}^{1 / 3}\right] /\left(\mathrm{T}^{\mathrm{o}}-\right.$ minimum $\mathrm{T}^{\mathrm{o}}$ to feed $)$

In biometric parameter (Table 3) there was an only statistical difference in HSI observing a gradual reduction of liver weight as vegetal substitution increased, and fish fed with $60 \%$ of PPC diet obtained the lowest percentage $(0.7 \%)(\mathrm{P}<0.05)$. In wholebody composition (Table 4), moisture, protein, lipid and ash content of fish carcass at the end of the growth trial were not affected by fish meal substitution. The retention of ingested protein (CPE) and ingested energy (GEE), there were also no statistical differences among diets.

Table 3. Responses of sharpsnout sea bream fed diets containing different percentages of total crude protein (CP) from PP for 125 days.

\begin{tabular}{|c|c|c|c|c|c|}
\hline & $\mathbf{0}$ & 16 & 32 & 48 & SEM \\
\hline Initial weight (g) & 14.07 & 14.43 & 13.57 & 14.23 & 0.36 \\
\hline Final weight (g) & $103.5^{\mathrm{c}}$ & $96.22^{\mathrm{b}}$ & $91.77^{\mathrm{ab}}$ & $89.04^{\mathrm{a}}$ & 1.59 \\
\hline $\mathrm{TCG} * 1000^{\mathrm{a}}$ & $1.82^{\mathrm{b}}$ & $1.72^{\mathrm{a}}$ & $1.70^{\mathrm{a}}$ & $1.63^{\mathrm{a}}$ & 0.02 \\
\hline $\operatorname{SGR}\left(\% \text { day }^{-1}\right)^{\mathrm{b}}$ & $1.60^{\mathrm{c}}$ & $1.54^{\mathrm{b}}$ & $1.50^{\mathrm{ab}}$ & $1.47^{\mathrm{a}}$ & 0.01 \\
\hline FIR (g $100 \mathrm{~g} \mathrm{fish}^{-1}$ day $\left.^{-1}\right)^{\mathrm{d}}$ & 2.16 & 2.06 & 2.11 & 1.94 & 0.09 \\
\hline $\mathrm{FCR}^{\mathrm{e}}$ & 1.91 & 1.84 & 1.90 & 1.78 & 0.08 \\
\hline
\end{tabular}




\begin{tabular}{lccccc} 
PER $^{\mathrm{f}}$ & 1.36 & 1.36 & 1.31 & 1.38 & 0.06 \\
CF $^{\mathrm{g}}$ & 1.91 & 1.96 & 1.96 & 2.04 & 0.11 \\
HSI $(\%)^{\mathrm{h}}$ & $0.96^{\mathrm{b}}$ & $0.77^{\mathrm{ab}}$ & $0.79^{\mathrm{ab}}$ & $0.66^{\mathrm{a}}$ & 0.07 \\
MFI (\%) & 1.17 & 1.23 & 1.42 & 1.32 & 0.23 \\
ISI (\%) & 1.62 & 2.10 & 1.91 & 1.60 & 0.25 \\
VSI (\%) & 6.53 & 6.22 & 6.45 & 7.12 & 0.34 \\
DP $(\%)^{\mathrm{i}}$ & 78.56 & 79.23 & 77.99 & 77.83 & 0.81 \\
\hline
\end{tabular}

Data in the same row with different superscripts differ at $(\mathrm{P}<0.05)$. All values are means of triplicate baskets $(n=3)$.

Initial weight was considerer as covariable for final weight and SGR.

${ }^{a}$ Thermal Growth Coefficient $(\mathrm{TGC})=1000 *\left[\mathrm{Fw}^{1 / 3}-\mathrm{Iw}^{1 / 3}\right] /\left(\mathrm{T}^{\mathrm{o}}\right.$-minimum $\mathrm{T}^{\mathrm{o}}$ to feed $)$.

${ }^{\mathrm{b}}$ Specific growth rate $(\%$ day- 1$), \mathrm{SGR}=100 \times \ln$ (final weight $/$ initial weight $) /$ days

${ }^{\mathrm{d}}$ Feed Intake ratio $\left(\mathrm{g} 100 \mathrm{~g}\right.$ fish $\left.{ }^{-1} \mathrm{day}^{-1}\right), \mathrm{FIR}=100 \mathrm{x}$ feed consumption $(\mathrm{g}) /$ average biomass $(\mathrm{g}) \mathrm{x}$ days.

Feed Conversion ratio, FCR $=$ feed intake $(\mathrm{g}) /$ weight gain $(\mathrm{g})$

${ }^{\mathrm{f}}$ Protein efficiency ratio PER = weight gain $(\mathrm{g}) /$ protein intake $(\mathrm{g})$

${ }^{\mathrm{g}}$ Condition Factor $(\mathrm{CF})=$ (body weight $(\mathrm{g}) /$ fork length $\left.(\mathrm{cm}) 3\right) \times 100$.

${ }^{\mathrm{h}}$ Hepatosomatic index $(\mathrm{HSI})=($ liver weight $(\mathrm{g}) /$ body weight $(\mathrm{g})) \times 100$.

${ }^{\mathrm{i}}$ Mesenteric fat $(\mathrm{MF})=($ mesenteric fat weight $(\mathrm{g}) /$ body weight $(\mathrm{g})) \times 100$.

${ }^{\mathrm{j}}$ Intestine Somatic Index (ISI) $=($ intestine weight $(\mathrm{g}) /$ body weight $(\mathrm{g})) \times 100$.

${ }^{\mathrm{k}}$ Viscerosomatic index $(\mathrm{VSI})=($ visceral weight $(\mathrm{g}) /$ body weight $(\mathrm{g})) \times 100$. /fish weight (g).

${ }^{1}$ Dressout percentage $(\%)(D P)=100 \times($ total fish weight - visceral weight - head weight $(\mathrm{g}))$

In relation to whole-body amino acid composition (Table 5) no statistical differences were observed for any amino acid. The retention of ingested amino acid (Table 6) showed only statistical difference in proline and fish fed $48 \%$ PPC inclusion obtained the highest value $(20.76 \%)$. Besides, methionine and glycine showed a marked increase in AA retention, while PPC inclusion increased.

Table 4. Proximate composition and protein and energy conversion efficiency of Diplodus puntazzo fed the experimental diets.

\begin{tabular}{lcccccc}
\hline & Initial & $\mathbf{0}$ & $\mathbf{1 6}$ & $\mathbf{3 2}$ & $\mathbf{4 8}$ & SEM \\
\hline Moisture (\%) & 69.57 & 63.59 & 64.81 & 64.12 & 65.26 & 0.47 \\
Crude Protein (\% ww) & 15.10 & 17.22 & 17.20 & 17.47 & 17.53 & 0.21 \\
Crude Lipid (\%ww) & 11.11 & 14.82 & 12.32 & 13.28 & 12.57 & 0.80 \\
Ash ((\%ww) & 4.39 & 3.72 & 3.93 & 4.04 & 3.99 & 0.15 \\
Retention & & & & & & \\
CPE (\%) & & 23.99 & 24.03 & 23.50 & 25.01 & 1.14 \\
GEE $(\%)^{\mathrm{z}}$ & & 26.48 & 23.78 & 24.15 & 25.10 & 1.76 \\
\hline
\end{tabular}

Different superscript letters denote significant differences within row $(\mathrm{P}<0.05)$. All values are means of triplicate baskets $(\mathrm{n}=12)$.

${ }^{\mathrm{y}}$ Crude protein efficiency, CPE $(\%)=($ Increment of protein corporally $(\mathrm{g})) \times 100 /$ (ingestion protein, $\left.(\mathrm{g})\right)$

${ }^{\mathrm{z}}$ Grow energy efficiency, GEE $(\%)=(\%)($ Increment of energy corporally, $(\mathrm{kJ}))$ x $100 /$ (ingestion de energy $\left.(\mathrm{kJ})\right)$

There were no differences in liver nuclei (LN), liver hepatocyte cytoplasm (LHC), hepatocyte vacuolation (HV) and pancreatic acinar cells (PAC). Hepatocytes in general presented a similar structure in all treatments, roundish polygonal cell body with clear nucleus with a nucleolus, with a quantity of lipid or glycogen in the cytoplasm (Table 7). In figure 2 there is observed the liver of different treatments, there is observed a similar pattern in all of them. 
Histological analysis, (Table 8) villous length, lamina propria, villous width and muscularis thickness were measured in the anterior, medium and posterior portions and mucus cells were counted. Comparing villous length (VL) and Lamina propria width among intestine portions, the posterior section was the longest and width of all three, in this experiment, but in general it was observed a tendency to increment VL as PPC inclusion increased. There was significant difference in PI among treatment; this was enlarging while PPC inclusion increased. In anterior intestine (AI) there was significant difference in lamina propria width and muscularis thickness and fish fed $48 \%$ PPC obtained the highest value in both parameters. Although, fish fed 12 and $48 \%$ PPC presented the lowest goblet cells number per segment. In mid intestine, fish fed the 0 and $48 \%$ PPC obtained the lowest value in villous width and the same time the highest amount of goblet cells. In posterior intestine (PI) differences were found in muscularis thickness and goblet cells and fish fed $0 \%$ PPC presented the lowest value in muscularis thickness and fish fed the maximum inclusion exhibited the highest cell number in goblet cells counting. It can observed in Figure 3 the PI portion of fish fed the four treatments.

\section{Discussion}

Survival at the end of the experimental period was higher in comparison to Hernández et al. (2007) and Chatzifotis et al. (2006) results and most of the death in this trial could be attributed to fish escapade.

Pea protein concentrate inclusion affected growth parameters, even the lowest inclusion (16\%) altered fish growth. On the contrary, in gilthead sea bream there was only significant difference in fish fed $480 \mathrm{~g} \mathrm{~kg}^{-1}$ PPC (Sánchez-Lozano et al. 2010). Besides, Carter and Hauler (2000); Thiessen et al. (2003) and Øverland et al. (2009), who also tested PPC in salmonids, reported no statistical differences up to $33 \%$ of substitution. Similar results, but with a higher substitution level (50\%), was reported by Davies and Gouveia (2008) in Clarias gariepinus. Although Schulz et al. (2007) obtained lowest growth in tilapia fingerlings fed up to $223 \mathrm{~g} \mathrm{~kg}^{-1}$ PPC inclusion and higher feed efficiency in fish fed up to $149 \mathrm{~g} \mathrm{~kg}^{-1}$ PPC inclusion.

The adverse growth results obtained in this trial could be due to the presence of some antinutrional compounds present in pea seeds, resistance to the process used to obtain PPC, such as protease inhibitors, lectins, tannins cyanogens, phytic acids, saponins, antivitamins (Francis, Makker \& Becker 2001). Some of these substances are known to reduce fish growth, like tannins and cyanogens. Besides, Schulz et al. (2007) commented that the process used to obtain the pea protein increased the phytic acid content in comparison to raw peas from $6-10 \mathrm{~g} \mathrm{~kg}^{-1}$ to $23-31 \mathrm{~g} \mathrm{~kg}^{-1}$. Besides, Fraczek et al. (2007) commented that PPC contained potential allergens for humans and animals. 
Table 5. Effects of dietary pea protein concentrate on whole-body amino acid composition at the end of the trial.

\begin{tabular}{|c|c|c|c|c|c|c|}
\hline Parameters & Initial & $\mathbf{0}$ & 16 & 32 & 48 & SEM \\
\hline \multicolumn{7}{|c|}{ Essential amino acids contain calculated on: $\mathrm{g} \mathrm{kg}^{-} \mathrm{ww}^{1}$} \\
\hline Arginine & 14.5 & 14.4 & 15.4 & 15.0 & 15.9 & 0.11 \\
\hline Histidine & 4.2 & 4.8 & 4.8 & 5.1 & 5.3 & 0.05 \\
\hline Isoleucine & 6.3 & 6.4 & 6.3 & 6.7 & 7.0 & 0.02 \\
\hline Leucine & 11.6 & 11.4 & 11.6 & 12.1 & 12.3 & 0.05 \\
\hline Lysine & 11.3 & 12.8 & 12.9 & 13.5 & 13.0 & 0.09 \\
\hline Methionine & 4.5 & 5.1 & 4.9 & 5.8 & 5.4 & 0.06 \\
\hline Phenylalanine & 7.3 & 6.6 & 6.6 & 7.0 & 7.7 & 0.07 \\
\hline Threonine & 7.1 & 7.5 & 7.5 & 7.5 & 8.1 & 0.05 \\
\hline Valine & 7.0 & 7.3 & 7.3 & 7.7 & 7.9 & 0.03 \\
\hline \multicolumn{7}{|c|}{ No essential amino acids contain calculated on: $g \mathrm{~kg}^{-1} \mathrm{ww}$} \\
\hline Alanine & 9.9 & 10.8 & 11.3 & 11.2 & 11.3 & 0.07 \\
\hline Aspartate & 14.3 & 16.1 & 15.5 & 15.8 & 15.9 & 0.12 \\
\hline Cystine & 3.3 & 3.4 & 3.1 & 4.3 & 3.9 & 0.05 \\
\hline Glutamine & 21.0 & 22.6 & 22.4 & 22.8 & 22.3 & 0.14 \\
\hline Glycine & 12.7 & 14.3 & 16.6 & 16.0 & 16.4 & 0.15 \\
\hline Serine & 6.9 & 7.8 & 7.3 & 7.5 & 7.8 & 0.06 \\
\hline Proline & 6.7 & 7.4 & 8.4 & 8.2 & 9.2 & 0.08 \\
\hline Tyrosine & 5.2 & 5.5 & 5.1 & 5.6 & 6.1 & 0.07 \\
\hline EAA/NEAA & 0.92 & 0.87 & 0.86 & 0.89 & 0.89 & \\
\hline
\end{tabular}

Data in the same row with different superscripts differ at $\mathrm{P}<0.05$. Dates are the mean of triplicate group per treatments \pm SEM (standard error of the pooled means).

EAA, Essential amino acids,; NEAA, Non-essential amino acids.

Despite of depressing fish growth at the end of the experiment, PPC did not affect feed efficiency parameters; similar results were reported by Sánchez-Lozano et al. (2010); Øverland et al. (2009); Davies and Gouveia (2008); Thiessen, et al. (2003) and Carter and Hauler (2000). They attributed these results to PPC characteristics like low carbohydrates content, low tripsin inhibitor $1.9 \mathrm{TIU} \mathrm{mg}^{-1}$ (Davies \& Gouveia 2008) and high lysine content in PPC (Sánchez-Lozano et al. 2010) in comparison to other form of pea meal (whole seed and dehulled) or treatment process (raw, extruded, autoclaved, etc). On the contrary Schulz et al. (2007) obtained differences up to $148.8 \mathrm{~g}$ $\mathrm{kg}^{-1}$ of PPC feeding juvenile Oreochromis niloticus attributing to an increase in phytic acid content due to the creation of complexes with proteins that could reduce feed efficiency and low mineral absorption. These could lead to indicate that feed efficiency could be conditioned by the process of elaboration (Sánchez-Lozano et al. 2010) or origin of raw material.

Only HSI in sharpsnout sea bream was affected by PPC inclusion, decreasing the liver size as the vegetable meal increased, although gilthead sea bream's liver was not affected by PPC inclusion (Sánchez-Lozano et al. 2009, 2010). Nevertheless Hernandez et al. (2007) obtained similar results with soybean meal inclusion in juveniles, but not in adults. The HSI could be attributed to the enzymatic activity that is higher in adults than juveniles (Tramati, Savona \& Mazzola 2005). Another reason, proposed by Russell, Davies, Gouveia and Tekinay (2001), could be the rapid absorption and assimilation of starch in the PPC diets that caused an increase in liver glycogen content observed in seas bass fed with 20 and $40 \%$ of pea seed meal, which produced a decrease in HSI. According to Li, Mai, Trushenski and Wu (2009), Arginine can stimulate the release of insulin and glucagon, hormones responsible of glycogen absorption in liver. And this 
EAA was increasing while PPC increased in experimental diets (Table 2). On the other side, higher glycogen deposition seemed to induce enlargement of gilthead sea bream and sea bass livers (Adamidou, 2008). As Aas, Hatlen, Grisdale-Helland, Terjesen, Penn, Bakke-McKellep, and Helland (2007) commented that halibut was most sensitive to alternative protein meal that produced a gradual reduction of liver than Atlantic salmon (Aas, Grisdale-Helland, Terjesen \& Helland 2006). As it is observed it seems that the reaction of a specific meal is related to the specie itself, more than to the alternative meal.

Pea protein concentrate did not affect corporal composition at the end of the trial; similar results were reported by Hernandez et al. (2007) and Nogales-Mérida et al. (2010) in the same specie as well as Sánchez-Lozano et al. (2010), Díaz, Conceicão, Ramalho Ribeiro, Borges, Valente and Dinis (2009) who tested in S. aurata. Protein and energy retention was similar in all treatments just like Nogales-Mérida et al. (2010) and Hernández et al. (2007) reported in juveniles of sharpsnout sea bream. Although Sánchez-Lozano et al. (2010) indicated a reduction in CPE as the vegetable protein increased in experimental diets.

The whole body amino acid composition of the juvenile sharpsnout sea bream was similar in all treatment, showing that AA of experimental diets did not affect its composition, similar values were obtained in gilthead sea bream fed with PPC (Sánchez-Lozano et al. 2010) and in a mixture of PPC and rice protein concentrate (Sánchez-Lozano et al. 2009). However, Nogales-Merida et al. (2010) reported statistical differences in some EAA (valine, leucine and aspartate) with a positive increase with sunflower meal inclusion. As well as Alam, Teshima, Yaniharto, Koshio and Ishikawa (2002), who fed Paralichthys olivaceus juveniles with semi-purified diets.

Table 6. Effects of dietary pea protein concentrate on amino acid retention at the end of the trial.

\begin{tabular}{lccccc}
\hline Parameters & $\mathbf{0}$ & $\mathbf{1 6}$ & $\mathbf{3 2}$ & $\mathbf{4 8}$ & SEM \\
\hline Essential amino acids & & & & \\
Arginine & 23.50 & 23.72 & 19.95 & 21.13 & 2.09 \\
Histidine & 18.61 & 19.58 & 21.08 & 25.04 & 2.92 \\
Isoleucine & 18.07 & 18.30 & 18.77 & 21.16 & 1.36 \\
Leucine & 19.90 & 20.33 & 19.92 & 21.29 & 1.47 \\
Lysine & 30.27 & 29.59 & 28.90 & 27.85 & 2.78 \\
Methionine & 32.31 & 35.57 & 46.87 & 53.98 & 6.80 \\
Phenylalanine & 13.04 & 13.24 & 13.39 & 16.26 & 1.98 \\
Threonine & 21.19 & 22.08 & 21.71 & 26.06 & 2.24 \\
Valine & 19.01 & 19.54 & 19.96 & 22.14 & 1.44 \\
No essential amino acids & & & & \\
Alanine & 24.75 & 28.26 & 28.38 & 32.35 & 2.36 \\
Aspartate & 26.24 & 24.33 & 22.75 & 23.18 & 2.50 \\
Cystine & 31.66 & 27.16 & 35.18 & 32.28 & 5.18 \\
Glutamine & 23.25 & 22.26 & 20.56 & 20.91 & 2.00 \\
Glycine & 27.64 & 35.99 & 35.62 & 43.13 & 4.45 \\
Serine & 25.96 & 23.49 & 21.94 & 23.26 & 2.45 \\
Proline & $10.48^{\mathrm{a}}$ & $13.80^{\mathrm{ab}}$ & $14.60^{\mathrm{ab}}$ & $20.76^{\mathrm{b}}$ & 1.88 \\
Tyrosine & 15.77 & 15.02 & 16.47 & 19.99 & 2.92 \\
Retention of ingested amino acid (\%) & Fish amino acid gain (g)/ingested amino acids (g) x 100. & \\
\end{tabular}


The essential amino acids retention did not present significant differences among treatments, but it was observed a tendency to compensate the lack of certain EAA in the highest inclusion levels (325 and $487 \mathrm{~g} \mathrm{~kg}^{-1}$ PPC), especially in methionine that increased from 32 to 54\%. Sánchez-Lozano et al. (2009) did not find significant difference in any EAA, although fish fed the $60 \%$ presented the highest retention except in lysine and methionine. Nevertheless, Sánchez-Lozano et al. (2010) reported significant differences in most of the EAA and fish fed the $48 \%$ of PPC diet presented the lowest value, attributing these differences to the highest ingestion and lowest growth that was not the case of sharpsnout sea bream. Nogales-Mérida et al. (2010) did not find significant differences in AA retention, attributing in part to sharpsnout sea bream omnivorous habits in nature (Mena Sellés \& Garcia Garcia 2002). If EAA retention is compared with other marine species like salmon, it was observed that EAA retention increased while bacterial protein meal (BPM) increased (Aas, Gridale-Helland, Terjesen $\&$ Helland 2006), although in halibut was higher until 18\% of BPM inclusion (Aas, Hatlen, Grisdale-Helland, Terjesen, Penn, Bakke-McKellp \& Helland 2007). In both cases, the AA retention was correlated to fish growth.
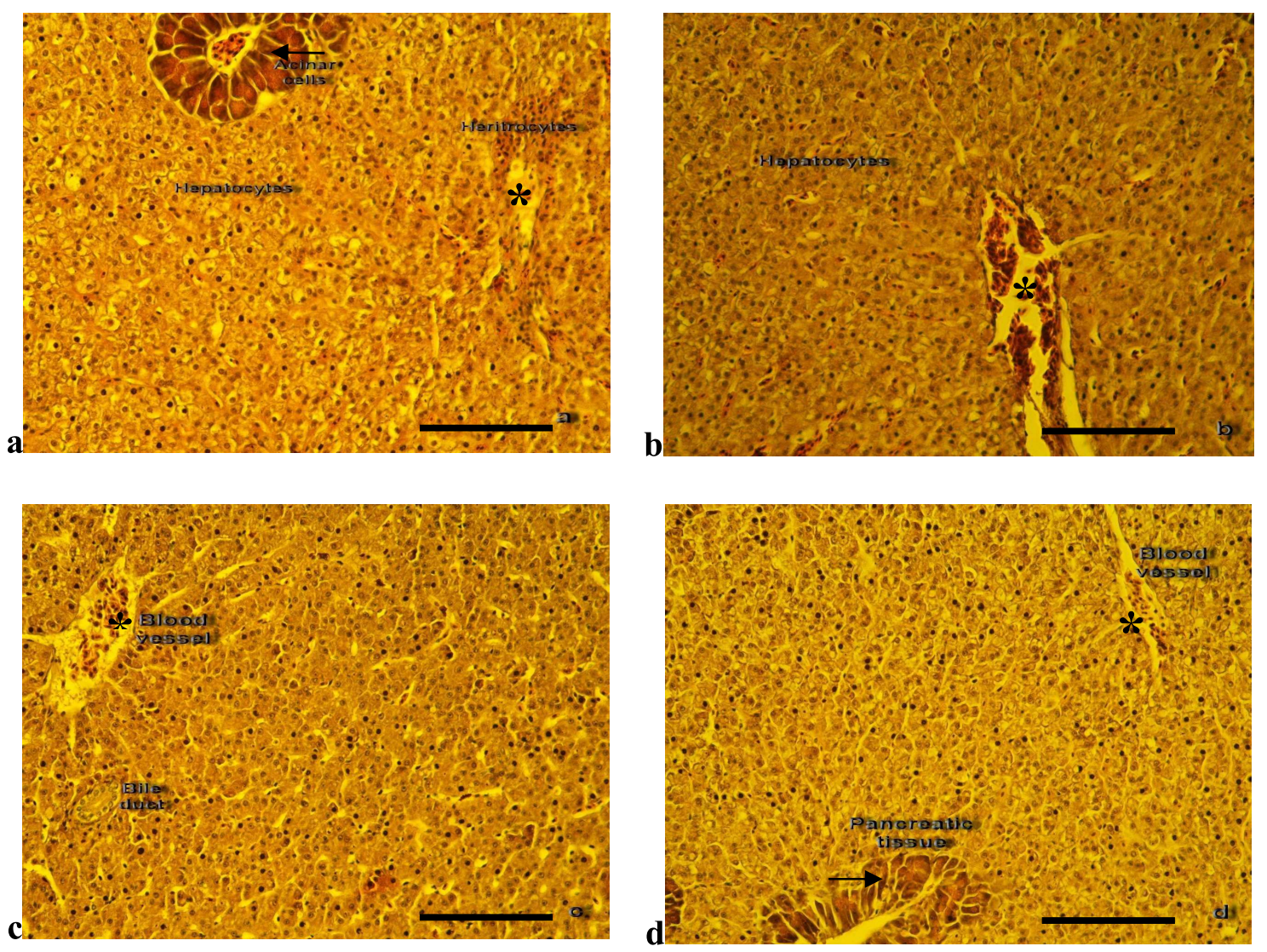

Figure 2. Photomicrograph of a $5-\mu \mathrm{m}$ thick section of sharpsnout sea bream liver stained with haematoxylin-eosin. (Barr $=100 \mu \mathrm{m})$. a) $0 \%$, b) 20\%, c) $40 \%$ and d) 60\%. Acinar cells (arrows). Blood vessels $(*)$.

Despite HSI reduction, hepatocyte morphology was not affected by treatments, nevertheless, hepatocytes quantification was related to HSI, showing a reduction of the cells sizes. This could be explained by Russell et al. (2001) results. They substituted fish meal by pea meal in sea bass, reported a high rate of liver glycogen storage compared to the control group. At the same time, these authors compared the relationships between dietary composition and the general hepatic architecture, and also 
observed a sinusoidal reduction in livers obtained from fish fed with pea meal diets and a more uniform appearance in the hepatocyte distribution and more compact cellular dimension, as well as an increase in glycogen deposition in livers of sea bass fed on the pea meal diets.

Table 7. Histological criteria for indices of condition of sharpsnout sea bream liver.

\begin{tabular}{cccccccccccccc}
\hline Diets & \multicolumn{2}{c}{ Liver nuclei } & \multicolumn{3}{c}{$\begin{array}{c}\text { Liver } \\
\text { hepatocyte } \\
\text { cytoplasm }\end{array}$} & \multicolumn{4}{c}{$\begin{array}{c}\text { Hepatic } \\
\text { vacuolation }\end{array}$} & \multicolumn{3}{c}{$\begin{array}{c}\text { Pancreatic } \\
\text { acinar cells }\end{array}$} \\
& 1 & 2 & 3 & 1 & 2 & 3 & 1 & 2 & 3 & 1 & 2 & 3 & $\mathrm{n}$ \\
\hline 0 & 6 & - & - & 4 & 2 & - & 2 & 4 & - & 4 & 2 & - & 6 \\
16 & 6 & - & - & 6 & - & - & 6 & - & - & 4 & 2 & - & 6 \\
32 & 4 & 2 & - & 6 & - & - & 4 & 2 & - & 4 & 2 & - & 6 \\
48 & 6 & - & - & 6 & - & - & 6 & - & - & 4 & 2 & - & 6 \\
\hline
\end{tabular}

Grade level evaluation: 1 (Healthy); 2 (Intermediate); 3 (Degraded).

Intestinal morphology, according to measure and quantification, were affected by treatments, especially in the villous length in distal intestine, which underwent a gradual elongation, showing that there was an augmentation of absorption rate as PPC inclusion increased. This portion is known to be the site of maximum absorption of protein or amino acids (Al-Hussaini, 1949 and Hepher 1988). Another possible cause to this elongation could be attributed not only to food type, but also to natural seasonal fluctuation (Brugger 1991), or perhaps a higher content of glutamine caused an increased in villous lengths like in Cyprinus carpio (Yan \& Qiu-Zhou 2006). This last fact could also affect sharpsnout sea bream because glutamine content increased as PPC increased in experimental diets.

Table 8. Histological values of liver and intestine of sharpsnout sea bream juveniles at the end of the trial.

\begin{tabular}{|c|c|c|c|c|c|}
\hline & $\mathbf{0}$ & 12 & 32 & 48 & SEM \\
\hline Hepatocytes $^{1}$ & $859^{\mathrm{b}}$ & $864^{\mathrm{b}}$ & $737^{\mathrm{a}}$ & $999^{b}$ & 32.8 \\
\hline \multicolumn{6}{|c|}{ Villous Length $(\mu \mathrm{m})$} \\
\hline AI & 658,2 & 724.0 & 759.3 & 887.7 & 68,1 \\
\hline MI & 549.0 & 585.2 & 593.3 & 630.3 & 36,4 \\
\hline PI & $835.3^{\mathrm{a}}$ & $1051.7^{\mathrm{ab}}$ & $1031.0^{\mathrm{ab}}$ & $1163.7^{b}$ & 60.2 \\
\hline \multicolumn{6}{|c|}{ Lamina propria width $(\mu \mathrm{m})$} \\
\hline $\mathrm{AI}$ & $14,3^{\mathrm{b}}$ & $19.5^{\mathrm{ab}}$ & $18.9^{\mathrm{ab}}$ & $23.7^{\mathrm{a}}$ & 2,4 \\
\hline MI & 17.2 & 17.8 & 22.3 & 17.3 & 2 \\
\hline PI & 27,7 & 28.7 & 27.5 & 25.6 & 4.47 \\
\hline \multicolumn{6}{|c|}{ Villous width $(\mu \mathrm{m})$} \\
\hline AI & 103,1 & 108.2 & 112.0 & 116.8 & 5,78 \\
\hline MI & $99^{\mathrm{b}}$ & $108.2^{\mathrm{ab}}$ & $119.6^{\mathrm{a}}$ & $98.6^{\mathrm{b}}$ & 4.3 \\
\hline PI & 146,3 & 124.2 & 122.8 & 117.8 & 8.3 \\
\hline \multicolumn{6}{|c|}{ Muscularis thickness $(\mu \mathrm{m})$} \\
\hline AI & $32,3^{\mathrm{a}}$ & $40.7^{\mathrm{ab}}$ & $39.5^{\mathrm{ab}}$ & $42.7^{\mathrm{b}}$ & 2,7 \\
\hline MI & 41.9 & 42.7 & 33.7 & 42.0 & 5.9 \\
\hline PI & $43,7^{\mathrm{a}}$ & $54.2^{\mathrm{b}}$ & $47.3^{\mathrm{ab}}$ & $40.7^{\mathrm{ab}}$ & 6.0 \\
\hline \multicolumn{6}{|c|}{ Goblet cells (number of cells per segment) } \\
\hline $\mathrm{AI}$ & $640^{\mathrm{c}}$ & $469^{\mathrm{a}}$ & $581^{\mathrm{b}}$ & $493^{\mathrm{a}}$ & 19,3 \\
\hline MI & $547^{\mathrm{bc}}$ & $435^{\mathrm{a}}$ & $475^{\mathrm{ab}}$ & $564^{\mathrm{c}}$ & 25,5 \\
\hline PI & $573^{\mathrm{a}}$ & $843^{\mathrm{a}}$ & $663^{\mathrm{a}}$ & $1046^{\mathrm{b}}$ & 40,8 \\
\hline
\end{tabular}


$\mathrm{AI}=$ anterior intestine; $\mathrm{MI}=$ mid intestine; $\mathrm{PI}=$ posterior intestine

Quantification of hepatocytes fluctuated among $737-999$ cells $/ 125.000 \mu^{2}$.

If these results are compared with those commented by Sanden, Bersntssen, Krogdahl, Hemre and Bakke-McKellep (2005) on Salmon salar morphology, the intestinal histology of sharpsnout sea bream fed with PPC could be considered moderate. Nevertheless, Øverland et al. (2009) concluded that PPC may replace $20 \%$ of fish meal protein in feeding Atlantic salmon without any morphological changes. On the contrary, deleterious effects were commented by Fernández-Quintela, Del Barrio, Macarulla and Martínez (1998) such as; an increment in intestinal weight attributed to the presence of lectins in PPC, which could interact with epithelial surface of the intestine, causing a hyperplasia as they observed in rats".
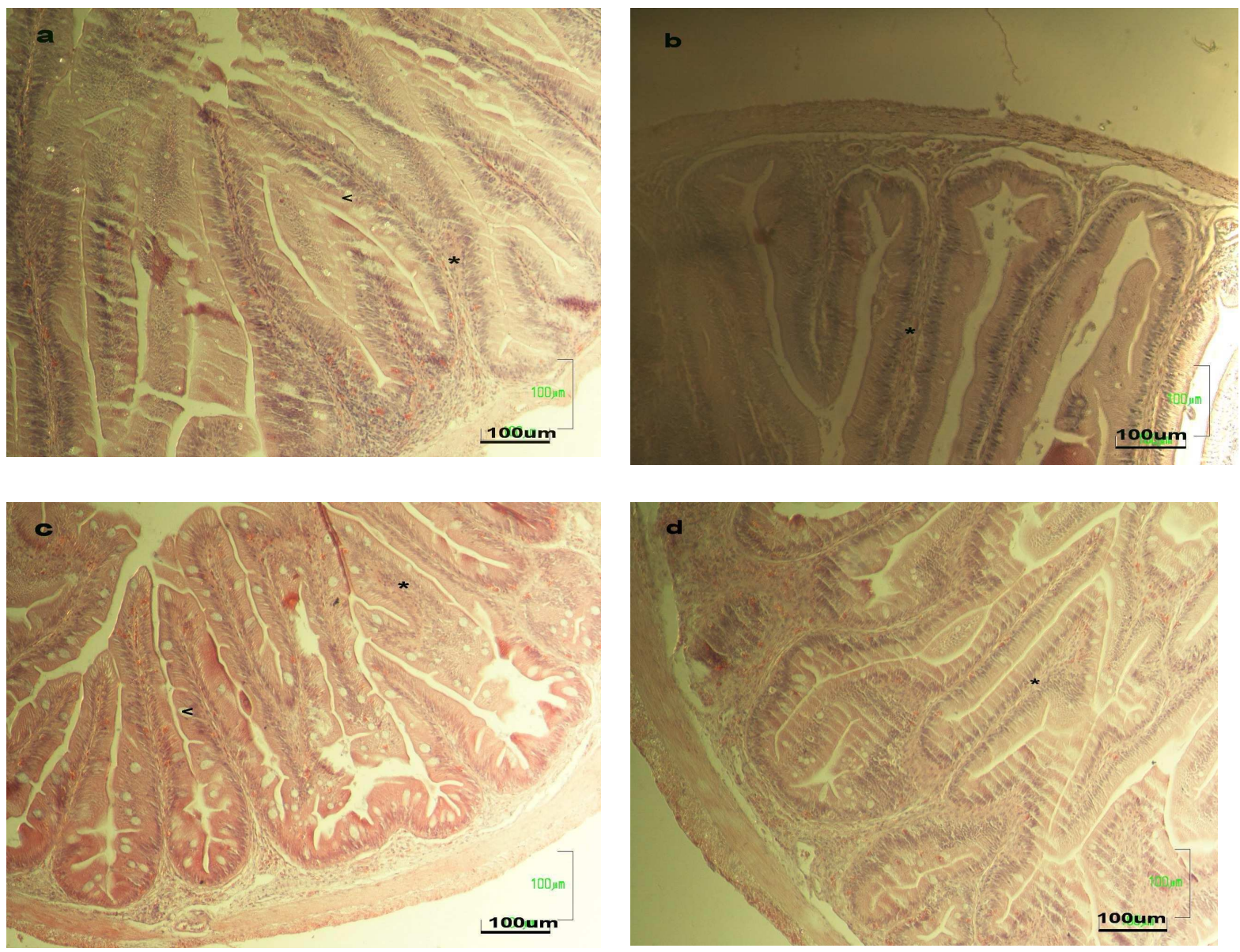

Figure 3. Histological details of the haematoxylin-eosin stained posterior villous folds $(5-\mu \mathrm{m}$ thick) of D. puntazzo fed the diet with $0 \%$ (a); $16 \%$ (b); $32 \%$ (c) and $48 \%$ (d) of pea protein (Barr size $100 \mu \mathrm{m})$.

$(*)$ Lamina propria, $(<)$ goblet cells.

In summary, this adverse effect could be due to the presence of antinutritional factors that enhanced in PPC instead of diminished, because of the process used to obtain this vegetable protein. It seemed that the presence of these substances and the morphology of the specie could contribute to alter gastrointestinal tract and reduce fish growth. 


\section{Conclusion}

The present trial showed that PPC diminished fish growth, but without affecting body and amino acids composition and retention. This vegetable protein also compromised gastrointestinal tract histology, especially in the distal portion length and number of goblet cells along the fish gut. Further research is needed to identify the causative agent(s) of gut alteration and fish growth reduction. Pea protein concentrate proved to be an inappropriate substitute to fish meal in sharpsnout sea bream juveniles rearing.

\section{Acknowledgements}

This work was financed by the Fisheries Unit of the Valencian Regional Government and JACUMAR (Spain).

\section{References}

Aas T.S., Grisdale-Helland B., Terjesen B.F. \& Helland S.J. (2006) Improved growth and nutrient utilization in Atlantic salmon (Salmo salar) fed diets containing a bacterial protein meal. Aquaculture, 259, 365 - 376.

Aas T.S., Hatlen B., Grisdale-Helland B., Terjesen B.F., Penn M., Bakke-McKellep A.M. \& Helland S.J. (2007) Feed intake, growth and nutrient utilization in Atlantic halibut (Hippoglossus hippoglossus) fed diets containing a bacterial protein meal. Aquaculture Research 38, $351-360$.

Adamidou, S. (2008) Effect of Extrusion on the nutritional value of peas (Pisum sativum), chickpeas (Cicer arietinum) and faba beans (Vicia faba) and inclusion in feeds for European seabass (Dicentrarchus labrax) and gilthead seabream (Sparus aurata) Doctoral Thesis, Institute of Aquaculture, University of Stirling, Stirling, Scotland. $210 \mathrm{pp}$.

Alam M.S., Teshima S-I., Yaniharto D., Koshio S., Ishikawa M. (2002) Influence of different dietary amino acid patterns on growth and body compositon of juvenile Japanese flounder, Paralichthys olivaceus. Aquaculture 210, 359 - 369.

Al-Hussaini AH. (1949) On the functional morphology of the alimentary tract of some fish in relation to differences in their feeding habits: Cytology and Physiology. Quarterly Journal Microscopical Science Vol. 90 (4), 323 - 354.

AOAC (1990). Official Methods of Analysis, $15^{\text {th }}$ end. Association of Official Analytical Chemists, Arlington, VA, USA, $1298 \mathrm{pp}$.

Baeverfjord G. \& Krogdahl Å. (1996) Development and regression of soybean meal induced enteritis in Atlantic salmon, Salmo salar L., distal intestine: a comparison with the intestines of fasten fish. Journal of Fish Disease 19, 375 - 387.

Bonaldo A., Roem A.J., Pecchini A., Grilli E. \& Gatta P.P. (2006) Influence of dietary soybean meal levels on growth, feed utilization and gut histology of Egyptian sole (Solea aegyptica) juveniles. Aquaculture 261, 580 - 586.

Bonaldo A., Roem A.J., Faagioli P., Pecchini A., Cipollini I. \& Gatta P.P. (2008.) Influence of dietary levels of soybean meal on the performance and gut histology of gilthead sea bream (Sparus aurata L.) and European sea bass (Dicentrarchus labrax L.) Aquaculture Research 39, 970 - 978.

Booth M.A., Allan G.L., Frances J. \& Parkinson S. (2001) Replacement of fish meal in iet for Australian silver perch, Bidyanus bidyanus IV. Effects of dehulling and protein concentration on digestibility of grain legumes. Aquaculture 196, $67-85$.

Bosch L., Alegria A. \& Farré R (2006) Application of the 6-aminoquinolyl-N-hydroxysuccinimidyl carbamate (AQC), reagent to the RP-HPLC determination of amino acids in infant foods. Journal of Chromatography. B. Anal Technology Biomedical Life Science 831, 176-183.

Brugger K.E. (1991) Anatomical adaptation of the gut to diet in red-winged blackbirds (Agelaius phoemiceus) The Auk 108, 562 -567. 
Carter C.G. \& Hauler R.C. (2000) Fish meal replacement by plant meals in extruded feeds for Atlantic salmon, Salmo salar L. Aquaculture 185, 299 - 311.

Catacutan M.R. \& Pagador G.E. (2004) Partial replacement of fishmeal by defatted soybean meal in formulated diets for the mangrove red snapper Lutjanus argentimaculatus (Forsskal 1775). Aquaculture Research 35, 299-306.

Chatzifotis S., Esteban A. \& Divanach P. (2006) Fishmeal replacement by alfalfa protein concentrate in sharp snout sea bream Diplodus puntazzo. Fishery Science 72, 1313 - 1315.

Davies S.J. \& Gouveia A. (2008) Enhancing the nutritional value of pea seed meals (Pisum sativum) by thermal treatment or specific isogenic selection with comparison to soybean meal for African catfish, Clarias gariepinus. Aquaculture 283, $116-122$.

Díaz J., Conceicão L.E.C., Ramalho Ribeiro A., Borges P., Valente L.M.P. \& Dinis M.T. (2009) Practical diet with low fish-derived protein is able to sustain growth performance in gilthead seabream (Sparus aurata) during the grow-out phase. Aquaculture 293, 255 - 262.

Evans J.J., Pasnik D.J., Peres H., Lim C. \& Klesius P.H. (2005) No apparent differences in intestinal histology of channel catfish (Ictalurus punctatus) fed heat-treated and non-heat-treated raw soybean meal. Aquaculture Nutrition 11, 123 - 129.

Fernández-Quintela A., Del Barrio A.S., Macarulla M.T. \& Martínez J.A. (1998) Nutritional evaluation and metabolic effects in rats of protein isolated obtained from seeds of three legume species. Journal of the Science of Food and Agriculture 78, 251 -260.

Frackek R.J., Kostyra E., Kostyra H. \& Krawczuk S. (2007) Immunoreactive properties of pea protein extract and its trypsin hydrolysates. Journal of Animal and Feed Sciences 16, 472 - 484.

Francis, G., Makker, H.P.S., Becker, K., 2001. Antinutritional factors present in plant -derived alternate fish ingredients and their effects in fish. Aquaculture 199, $197-227$.

Grisdale-Helland B., Helland S.J., Baeverfjord G. \& Berge G.M. (2002) Full-fat soybean meal in diets for Atlantic halibut: growth, metabolism and intestinal histology. Aquaculture Nutrition. 8, 265 - 270.

Hepher B. (1988) Nutrition of pound fish. Cambridge University Press, Cambridge, Great Britain, 385pp.

Hernandez M.D., Martínez F.J., Jover M. \& García García B. (2007) Effects of partial replacement of ifhs meal by soybean meal in sharpsnout sea bream (Diplodus puntazzo) diet. Aquaculture 263, 159-167.

Krogdahl Å., Bakke-McKellep A.M. \& Baeverfjord G. (2003) Effects of graded levels of standard soybean meal on intestinal structure, mucosal enzyme activities, and pancreatic responsse in Atlantic salmon (Salmo salar L.) Aquaculture Nutrition 9, 361 - 371.

Li P., Mai K., Trushenski J. \& Wu. G. (2009) New developments in fish amino acid nutrition : towards functional and environmentally oriented aquafeeds. Amino Acids 37, 43 - 53.

Lundstedt L.M. (2004) Adaptative histological variations in the gut of Pintado (Pseudoplatystoma corruscans) fed different protein levels. Biology Congress 2004 (Manaus - Brasil) 33 - 44pp.

Marcouli P.A., Alexis M.N., Andriopoulou A. \& Iliopoulou-Georgudaki J. (2004) Development of a reference diet for use in indispensable amino acid requirement sutides of gilthead seabream Sparus aurata L. Aquaculture Nutrition 10, 335 - 343.

McFadzen I.R.B., Coombs S.H. \& Halliday N.C. (1997) Histological indices of the nutritional condition of sardine, Sardina pilchardus (Walbaum) larvae off the north coast of Spain. Journal of Experimental Marine Biology and Ecology 212, 239 - 258.

Mena Sellés C. \& García García B. (2002) Importancia de la proteína vegetal en la dieta natural de poblaciones salvajes de Sargo picudo Diplodus puntazzo (Cetti, 1777); sus implicaciones en el cultivo intensivo. AquaTIC No 17 www.revistaaquatic.com/swusyiv/hyml/sty1705/sargo.htm

Nogales-Mérida S., Tomás-Vidal A., Martínez-Llorens S. \& Jover Cerdá M. (2010) Sunflower meal as a partial substitute in juvenile sharpsnout sea bream (Diplodus puntazzo) diets: amino acid retention, gut and liver histology. Aquaculture 298, 275 - 281.

Øverland M., Sørensen M., Storebakken T., Penn M., Krogdahl A. \& Skrede A. (2009) Pea protein concentrate substituting fish meal or soybean meal in diets for Atlantic salmon (Salmo salar) - Effect 
on growth performance, nutrient digestibility, carcass composition, gut health and physical feed quality. Aquaculture 288, $305-311$.

Piedecausa M.A., Mazón M.J., García García B. \& Hernández M.D. (2007) Effects of total replacement of fish oil by vegetable oils in the diets of sharpsnout sea bream (Diplodus puntazzo). Aquaculture 263, $211-219$.

Penn M.H., Bendiksen E.A., Campbell P. \& Krogdahl, A. (2011) High level of dietary pea protein concentrate induces enteropathy in Atlantic salmon (Salmo salar L.) Aquaculture 310, 267 - 273.

Rana K.J., Siriwardena S. \& Hasan M.R. (2009) Impact of rising feed ingredient prices on aquafeeds and aquaculture production. FAO Fisheries and Aquaculture Technical paper. Rome - Italy. 78 pp.

http://www.fao.org/docrep/012/i1143e/i1143e.pdf http://www.fao.org/docrep/012/i1143e/i1143e.pdf

Rondán M., Hernández M.D., Egea M.A., García B., Jover M., Rueda F.M. \& Martínez F.J. (2004) Effects of fishmeal replacement with soybean meal as protein source, and protein replacement with carbohydrate as an alternative energy source on sharpsnout seas bream, Diplodus puntazzo, fatty acid profile. Aquaculture Research 35, 1220 - 1227.

Russell P.M., Davies S.J., Gouveia A. \& Tekinay A.A. (2001) Influence of dietary starch source on liver morphology in juvenile cultured European sea bass (Dicentrarchus labrax L). Aquaculture Research 32, (1) $306-314$.

Sánchez-Lozano N.B., Martínez-Llorens S., Tomás-Vidal A. \& Jover Cerdá M. (2009) Effect of highlevel dfish meal replacement by pea and rice concentrate proteína on growth, nutrient utilization and fillet quality in gilthead seabream (Sparus aurata, L) Aquaculture 298, 83 - 89.

Sánchez-Lozano N.B., Martínez-Llorens S., Tomás-Vidal A. \& Jover Cerdá M. (2010) Amino acid retention of gilthead sea bream (Sparus aurata L.) fed with pea protein concentrate. Aquaculture Nutrition 17, $604-614$.

Sanden M., Bersntssen M.H.G., Krogdahl Å., Hemre G-I. \& Bakke-McKellep A-M (2005) An examination of the intestinal tract of Atlantic salmon Salmo salar L., parr fed different varieties of soy and maize. Journal of Fish Diseases 28, 317 - 330.

Schulz C., Wickert M., Kijora C., Ogunki J. \& Rennert B. (2007) Evaluation of pea protein isolated as alternative protein sources in diets for juvenile tilapia (Oreochromis niloticus). Aquaculture Research 38, $537-545$.

Sitjà-Bobadilla A., Peña-Llopis S., Gómez-Requeni P., Médale F., Kaushik S. \& Pérez-Sánchez J. (2005) Effect of fish meal replacement by plant protein sources on non-specific defence mechanisms and oxidative stress in gilthead sea bream (Sparus aurata). Aquaculture 249, 387 - 400.

Snedecor G. \& Cochran W. (1971) Statistical Methods. 593 p. The Iowas State University Press. Ames. Iowa, USA

Thiessen D.L., Campbell G.L. \& Tyler R.T. (2003) Utilization of thin distillers' solubles as a palatability enhancer in rainbow trout (Oncorhynchus mykiss) diets containing canola meal or air-classified pea protein. Aquaculture Nutrition 9, 1 - 10.

Tramati C., Savona B. \& Mazzola A. (2005) A study of the pattern of digestive enzymes in Diplodus puntazzo (Cetti, 1777) (Osteichthyes, Spariedae): evidence for the definition of nutritional protocols. Aquaculture International 13, 89 - 95.

Urán P.A., Gonçalvex A.A., Taverne-Thiele J.J., Schrama J.W., Verreth J.A.J. \& Rombout J.H.W.M. (2008) Soybean mealinduces intestinal inflammation in common carp (Cyprinus carpio L.) Fish \& Shellfish Immunology 25, 751 - 760 .

Urán P.A., Schrama J.W., Jaafari S., Baardsen G., Rombout J.H.W.M., Koppe W. \& Verreth J.A.J. (2009) Variation in commercial sources of soybean meal influences the severity of enteritis in Atlantic salmon (Salmo salar L.). Aquaculture Nutrition 15, 492 - 499.

Yan L. \& Qui-Zhou X. (2006) Dietary glutamine supplementation improves structure and function of intestine of juvenile Jian carp (Cyprinus caripio var. Jian). Aquaculture 256, 389 - 394. 



\section{CAPÍTULO 6}

A study of parcial replacement of fish meal with sunflower meal on growth, amino acid retention, and body composition of sharpsnout seabream, Diplodus puntazzo (Actinopterygii): Perciformes: Sparidae)

Acta Ichthyologica et Piscatoria, (2011) 41 (1): 47 - 54. 



\title{
A STUDY OF PARTIAL REPLACEMENT OF FISH MEAL WITH SUNFLOWER MEAL ON GROWTH, AMINO ACID RETENTION, AND BODY COMPOSITION OF SHARPSNOUT SEABREAM, DIPLODUS PUNTAZZO (ACTINOPTERYGII: PERCIFORMES: SPARIDAE)
}

\author{
Silvia NOGALES MÉRIDA, Miguel JOVER CERDÁ, Silvia MARTÍNEZ \\ LLORENS, and Ana TOMÁS VIDAL*
}

Institute of Animal Science and Technology, Group of Aquaculture and Biodiversity and Polytechnic University of Valencia

Nogales Mérida S., Tomás Vidal A., Martínez Llorens S., Jover Cerdá M. 2011. A study of partial replacement of fish meal with sunflower meal on growth, amino acid retention, and body composition of sharpsnout seabream, Diplodus puntazzo (Actinopterygii: Perciformes: Sparidae). Acta Ichthyol. Piscat. 41 (0): 00-00.

Background. Our previous study demonstrated that sharpsnout seabream, Diplodus puntazzo (Walbaum, 1792), can be fed with up to $34.8 \%$ sunflower meal (SFM), with excellent results in growth parameters and feed efficiency. The aim of the current study was to test the replacement of fish meal with SFM in the diet formulation for sharpsnout seabream and to evaluate growth, nutritive parameters, amino acid retention, and body composition of the fish during the fattening period.

Material and Methods. Sixteen baskets (300 L capacity), each with thirteen fish, were distributed in a recirculated saltwater system to allow four experimental diets containing $40 \%$ crude protein (CP) and $20 \%$ crude lipid (CL) with $0 \%, 11.7 \%, 23.5 \%$, and $34.8 \%$ SFM partially replacing fish meal to be used in quadruplicate for this experiment. The fish were fed these diets ad libitum during the experiment, which lasted for 162 days. Growth, nutrition efficiency, biometrics, carcass composition, amino acid composition, and amino acid retention of the experimental fish were evaluated.

Results. There were no statistical differences in the growth parameters among the treatments. However, fish fed a diet containing 34.8\% SFM had the lowest feed intake (FI), lowest feed conversion ratio (FCR), and the highest protein efficiency ratio (PER). There were also no statistical differences in the biometric parameters although fish fed the diet containing 10\% SFM had the lowest CP levels. Leucine was the only difference in the essential amino acid (EEA) profile with fish fed a diet containing 11.7\% SFM having the lowest levels of leucine. Although there were fluctuations among the amino acid retentions, they were not statistically significant.

Conclusions. SFM (up to $34.8 \%$ ) can be included in the diets of sharpsnout seabream, thereby, replacing $27 \%$ of the fish meal without altering the fish growth.

Keywords: Diplodus puntazzo, protein sources, sunflower meal (SFM), amino acid composition and retention

\footnotetext{
* Correspondence: Dr. Ana Tomás Vidal, Departamento de Ciencia Animal, Universidad Politécnica de Valencia, Camino de Vera, 14, 46071 - Valencia, Spain, phone: 34-96-3879385, fax: 34-96-3877439, e-mail: atomasv@dca.upv.es
}

Sharpsnout seabream, Diplodus

INTRODUCTION puntazzo (Walbaum, 1792), are omnivorous fish of increasing interest in 
aquaculture production as an alternative product to gilthead seabream and sea bass in the European market, especially in Spain. In recent years, several researchers studying sharpsnout seabream in the fattening period before they reached market size documented that this species has a lower increasing weight than those reported to gilthead sea bream, but similar lower increasing weights when compared to gilthead seabream but has similar increasing weights [the same time of weight increase as...? I am not sure if I understand this correctly] to sea bass (22 months) and Pagrus pagrus (20 months). Only three reports have described fish meal replacement by vegetal sources in sharpsnout seabream, such as replacement by soybean meal (Rondán et al. 2004, Hernández et al. 2007) and alfalfa meal (Chatzifotis et al. 2006).

According to Ahmad et al. (2004), sunflower meal (SFM) is an important byproduct obtained following the extraction of oil from sunflower seeds used for livestock feed. SFM is a rich source of good quality protein that is available at a low price when compared with other sources of vegetal proteins. Sunflower seeds also contain a large amount of phenolic compounds, such as chlorogenic-, quinic-, and caffeic acids (Gandhi et al. 2008), but these substances may be reduced by common processing techniques, such as dry and wet heating, although heat treatment may decrease the nutritional quality of proteins and carbohydrates (Francis et al. 2001). However, due to the absence of an effective dehulling process, the fibre content of sunflower seeds remains fairly high $(15 \%-24 \%)$ limiting the use of SFM in fish nutrition. The following maximal substitutions of SFM were obtained without statistical differences: $12 \%$ in gilthead seabream (Sánchez Lozano et al. 2007); 22\% in rainbow trout (Martínez 1984, Sanz et al. 1994); 60\% in tilapia (Furuya et al. 2000, Maina et al. 2003); and $20 \%$ in Tilapia randalli fingerlings.
Similarly, in Atlantic salmon, SFM substitution up to $33 \%$ was reported without any adverse effects on final fish weight (Gill et al. 2006). The metabolisable energy of SFM is low (8371 $\mathrm{kJ} \cdot \mathrm{kg}^{-1}$ ) when compared to other oil meals (Ahmad et al. 2004). According to Furuya et al. (2000), the limiting factors of sunflower meal utilisation in fish nutrition include high crude fibre (CF) content and a low lysine level.

The aim of this study was to evaluate if SFM protein could be used to replace fish meal in the diet formulation for sharpsnout seabream and to study the effects of these new diets on growth, nutrient utilisation, body composition and amino acid retention of the sharpsnout seabream.

\section{MATERIAL AND METHODS}

Sharpsnout seabream were obtained from an Italian commercial hatchery and were stocked in two cylindrical fibreglass tanks (1750 L) inside a recirculated seawater system. The fish were kept in these tanks and were fed $a d$ libitum with a diet containing $45 \%$ crude protein (CP) and $20 \%$ crude lipid (CL) for a month before the experiment started. The feeding trial was conducted at the aquaculture laboratory (Animal Science Department at the Polytechnic University of Valencia, Valencia, Spain). Two hundred and eight fish (average weight 106 $\pm 1.7 \mathrm{~g}$ ) were randomly placed into sixteen baskets ( $300 \mathrm{~L}$ capacity) with two fish per cylindrical fibreglass tank $(750 \mathrm{~L})$. The tanks were set up in a marine water recirculation system $\left(30 \mathrm{~m}^{3}\right.$ capacity) with a rotary mechanic filter and a gravity biofilter with an approximate capacity of $36 \mathrm{~m}^{3}$. All tanks were equipped with aeration, and the water was heated by a heat pump installed in the system. The following equipment was used to control water parameters: an oxymeter (OxyGuard, Handy Polaris V 1.26), a refractometer with $0 \%-100 \%$ capacity (Zuzi A67410) and a kit using the colorimetric method to 
determinate nitrate $\left(\mathrm{NO}_{3}-\mathrm{N}\right)$, ammonia $\left(\mathrm{NH}_{3}-\mathrm{N}\right)$ and nitrite nitrogen $\left(\mathrm{NO}_{2}-\mathrm{N}\right)$. The kits were obtained from AquaMerck (Merck KGaA, Darmstadt, Germany). The water temperature $\left(22.29 \pm 3.7^{\circ} \mathrm{C}\right)$ and dissolved oxygen $\left(6.04 \pm 0.7 \mathrm{mg} \cdot \mathrm{L}^{-1}\right)$ were measured daily. The salinity $(30.05 \pm 4.3$ $\left.\mathrm{g} \cdot \mathrm{L}^{-1}\right), \mathrm{pH}(6.7 \pm 1.0), \mathrm{NH}_{3}-\mathrm{N}(0.05 \pm 0.1$ $\left.\mathrm{mg} \cdot \mathrm{L}^{-1}\right), \mathrm{NO}_{2}-\mathrm{N}\left(0.34 \pm 0.2 \mathrm{mg} \cdot \mathrm{L}^{-1}\right)$, and $\mathrm{NO}_{3}-\mathrm{N}\left(41.1 \pm 33.7 \mathrm{mg} \cdot \mathrm{L}^{-1}\right)$ were measured three times a week. The photoperiod was natural, and all tanks had similar light conditions. Each experimental diet was tested in quadruplicate.

Four experimental diets were formulated (Table 1), and each diet contained $45 \% \mathrm{CP}$, approximately 22.45 $\mathrm{MJ} \cdot \mathrm{kg}^{-1}$ of energy and one of the four levels of SFM $(0 \%, 11.7 \%, 23.5 \%$, and $34.8 \%$ ). The $11.7 \%, 23.5 \%$, and $34.8 \%$ SFM inclusion levels were calculated for replacing the following levels of fish meal: $8.8 \%, \quad 17.7 \%$, and $27 \%$, respectively. While preparing the diets, wheat and SFM were ground to a fine particle size in a hammer mill (Technochufa, Valencia, Spain). All ingredients were then thoroughly mixed with vitamins and minerals. The diets were prepared by extrusion cooking with a semi-industrial twin-screw extruder (Clextral BC-45, St. Etienne, France), which helped to destroy harmful microorganisms while minimising the loss of nutrients or flavours. The processing conditions were as follows: 100 rpm screw speed, $110^{\circ} \mathrm{C}$ temperature, $4053-5066-\mathrm{kPa}$ pressure and $2-3 \mathrm{~mm}$ diameter pellets according to fish size. The diets were stored in plastic buckets at room temperature until they were fed to the fish. All diets were administered within three months of being manufactured.

The experiment lasted for 162 days (July 302008 through January 8 2009). The experimental diets were hand fed to the fish to apparent visual satiety twice daily $(0900 \mathrm{~h}$ and $1700 \mathrm{~h})$ for five days a week and just once on Saturday
$(1000 \mathrm{~h})$. Feed intake (FI) was carefully monitored to minimise feed wastage.

During the experimental period, fish were fasted for $24 \mathrm{~h}$ followed by anaesthetisation with $30 \mathrm{mg} \cdot \mathrm{L}^{-1}$ of clove oil (Guinama, Valencia, Spain) containing $87 \%$ Eugenol. The fish were bulk weighed and counted every three weeks, except at the beginning and end of the experiment when all fish were weighed individually.

Pooled samples of five fish from the initial stock population and four fish from each basket at the end of the experiment were taken to record the biometric parameters and were stored at $20^{\circ} \mathrm{C}$ for subsequent whole body composition analyses.

Chemical analyses of the dietary ingredients were determined prior to diet formulation. The diets, ingredients in the diets and the whole fish were analysed according to AOAC (Anonymous 1990) procedures as follows: dry matter $\left(105^{\circ} \mathrm{C}\right.$ to constant weight); ash (incinerated at $550^{\circ} \mathrm{C}$ to constant weight); $\mathrm{CP}(\mathrm{N} \times 6.25)$ by the Kjeldahl method after acid digestion (Kjeltec 2300 Auto Analyser, Tecator, Höganas, Sweden); CL extraction with methyl ether (Soxtec 1043 extraction unit; Tecator); and $\mathrm{CF}$ by acid and basic digestion (Fibertec System M. 1020 Hot Extractor; Tecator). All analyses were performed in triplicate.

Following the method previously described by Bosch et al. (2006), the amino acids from fish carcasses and diets were analysed by a Waters HPLC system (Waters 474; Waters, Milford, MA, USA) consisting of two pumps (Model 515; Waters), an auto sampler (Model 717; Waters), a fluorescence detector (Model 474; Waters) and a temperature control module. Amino butyric acid was added as an internal standard pattern before hydrolysation. The amino acids were derivatised with 6-aminoquinolyl-Nhydroxysuccinimidyl carbamate (AQC). Methionine and cysteine were determined separately as methionine sulphone and cysteic acid after oxidation with performic 
acid. Amino acids were separated with a C-18 reverse-phase column (Waters Acc.
Tag; $150 \mathrm{~mm} \times 3.9 \mathrm{~mm}$ ) and were then transformed into methionine and cysteine.

Table 1

Ingredients composition of the experimental diets tested on sharpsnout seabream, Diplodus

puntazzo

\begin{tabular}{lllll}
\hline Ingredient $\left[\mathrm{g}^{\mathrm{kg}} \mathrm{kg}^{-1}\right]$ & $0 \% \mathrm{SFM}$ & $11.7 \mathrm{SFM}$ & $23.5 \mathrm{SFM}$ & $34.8 \mathrm{SFM}$ \\
\hline Fish meal, herring & 603 & 550 & 496 & 440 \\
Sunflower meal & 0 & 117 & 235 & 348 \\
Wheat & 200 & 132 & 64 & 3 \\
Dextrine & 50 & 50 & 50 & 50 \\
Soybean oil & 46 & 46 & 46 & 46 \\
Fish oil & 91 & 95 & 99 & 103 \\
Vitamin mix & 6.3 & 6.3 & 6.3 & 6.3 \\
Mineral mix & 2.2 & 2.2 & 2.2 & 2.2 \\
Vitamin C & 1.5 & 1.5 & 1.5 & 1.5 \\
\hline
\end{tabular}

${ }^{a}$ The vitamin mix (values are $\mathrm{g} \cdot \mathrm{kg}^{-1}$ except to those in parenthesis) included the following:, 20; Choline, 10; DL- $\infty$-tocopherol , 5; and ascorbic acid, 5. retinol acetate (1 $000000 \mathrm{IU} / \mathrm{kg})$; calciferol (500 IU/kg); DL- $\infty$-tocopherol, 10; menadione sodium bisulphite, 0.8 ; thiamin hydrochloride, 2.3 ; riboflavin, 2.3; pyridoxine hydrochloride, 15; cyanocobalamin, 25; nicotinamide, 15; pantothenic acid, 6; folic acid, 0.65; biotin, 0.07; ascorbic acid, 75; inositol, 15; betaine, 100; and polypeptides.

${ }^{b}$ The mineral mix included the following: $\mathrm{Zn}, 5 ; \mathrm{Se}, 0.02 ; \mathrm{I}, 0.5 ; \mathrm{Fe}, 0.2 ; \mathrm{Cu} 15 ; \mathrm{Mg}$, 5.75; Co, 0.02; excpt. to $1000 \mathrm{~g}$ (Source: Dibaq-Diproteg).

The growth data and nutritive parameters were treated using multifactor analysis of variance (ANOVA) introducing the initial live weight as a covariate (Snedecor and Cochran 1971). The Newman-Keuls test was used to assess specific differences among diets at a significance level of $P<0.05$ (Statgraphics, Statistical Graphics System, Version Plus 5.1, Herndon, VA, USA).
Nowadays, there is not a specific regulation about fish welfare in Spain, especially animal used in experiments, but here in the Polytechnic University of Valencia, there is an Animal Welfare Commission, and all experiments were carried out according to the Animal Welfare Commission's rules or protocols.

Table 2

Proximate composition and amino acid composition of ingredients and experimental diets tested on sharpsnout seabream, Diplodus puntazzo 
Diet

\begin{tabular}{|c|c|c|c|c|c|c|c|}
\hline \multicolumn{2}{|c|}{ Component } & Fish meal & SFM & $0 \mathrm{SFM}$ & 11.7 SFM & 23.5 SFM & $34.8 \mathrm{SFM}$ \\
\hline \multicolumn{2}{|c|}{ Dry matter $[\% \mathrm{DM}]$} & 92.84 & 90.00 & 92.43 & 92.89 & 93.37 & 94.26 \\
\hline \multicolumn{2}{|c|}{ Crude protein $[\% \mathrm{DM}]$} & 71.20 & 38.33 & 45.48 & 45.48 & 44.99 & 44.42 \\
\hline \multicolumn{2}{|c|}{ Crude lipid [\% DM] } & 9.98 & 2.17 & 20.84 & 20.92 & 21.53 & 21.02 \\
\hline \multicolumn{2}{|c|}{ Ash $[\% \mathrm{DM}]$} & 16.75 & 7.96 & 11.64 & 11.45 & 11.22 & 11.23 \\
\hline \multicolumn{2}{|c|}{ Crude fibre $[\% \mathrm{DM}]$} & 0 & 23.00 & 0.48 & 2.28 & 4.85 & 7.44 \\
\hline \multicolumn{2}{|c|}{ NFE $[\%$ DM $]$} & 0 & 28.5 & 21.55 & 19.87 & 17.40 & 15.89 \\
\hline \multicolumn{2}{|c|}{ Gross energy $\left[\mathrm{kJ} \mathrm{g}^{-1} \mathrm{DM}\right]$} & 20.99 & 15.04 & 22.96 & 22.69 & 22.38 & 21.78 \\
\hline \multicolumn{2}{|c|}{$\mathrm{CP} / \mathrm{GE}\left[\mathrm{g} \mathrm{MJ}^{-1}\right]^{\mathrm{c}}$} & 34.65 & 25.48 & 19.81 & 20.04 & 20.10 & 20.39 \\
\hline \multirow{9}{*}{ 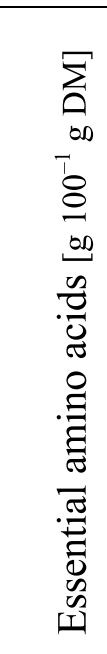 } & Arginine & 6.13 & 3.07 & 3.65 & 3.66 & 3.68 & 3.67 \\
\hline & Histidine & 2.64 & 1.09 & 1.50 & 1.48 & 1.46 & 1.44 \\
\hline & Isoleucine & 3.51 & 1.69 & 2.00 & 2.01 & 2.01 & 2.00 \\
\hline & Leucine & 5.62 & 2.42 & 3.33 & 3.29 & 3.24 & 3.18 \\
\hline & Lysine & 4.40 & 1.07 & 3.02 & 2.86 & 2.70 & 2.53 \\
\hline & Methionine & 1.61 & 0.59 & 1.23 & 1.18 & 1.14 & 1.09 \\
\hline & Phenylalanine & 4.89 & 2.32 & 2.33 & 2.37 & 2.41 & 2.44 \\
\hline & Threonine & 3.57 & 1.45 & 2.11 & 208 & 2.05 & 2.00 \\
\hline & Valine & 3.83 & 1.92 & 2.32 & 2.32 & 2.32 & 2.30 \\
\hline \multirow{8}{*}{ 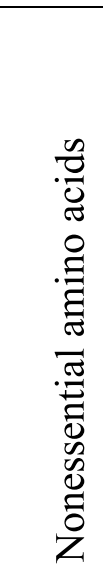 } & Alanine & 4.42 & 1.58 & 2.90 & 2.81 & 2.72 & 2.61 \\
\hline & Asparagine & 6.27 & 3.19 & 4.09 & 4.08 & 4.06 & 4.02 \\
\hline & Cystine & 1.00 & 1.17 & 0.85 & 0.90 & 0.95 & 0.99 \\
\hline & Glutamine & 8.92 & 6.95 & 6.14 & 6.26 & 6.39 & 6.48 \\
\hline & Glycine & 5.32 & 2.55 & 3.23 & 3.22 & 3.21 & 3.18 \\
\hline & Proline & 7.00 & 3.30 & 4.14 & 4.11 & 4.07 & 4.01 \\
\hline & Serine & 2.96 & 1.73 & 1.91 & 1.92 & 1.93 & 1.92 \\
\hline & Tyrosine & 3.57 & 0.97 & 1.72 & 1.67 & 1.63 & 1.57 \\
\hline \multicolumn{2}{|c|}{ EAA/NEAA } & 0.92 & 0.73 & 0.86 & 0.85 & 0.84 & 0.83 \\
\hline
\end{tabular}

${ }^{\mathrm{a}}$ Nitrogen Free Extract (NFE) $\%=100-\mathrm{CP} \%-\mathrm{CL} \%-\mathrm{Ash} \%-\mathrm{CF} \%$.

Crude Protein $(\mathrm{CP}) \%=(($ Titration volume for the sample $(\mathrm{ml})-($ Titration volume for the blank $(\mathrm{ml})) * 0.875) /$ sample weight $(\mathrm{g})$

Crude Lipid (CL) \% $=100 *(($ Weight of beaker and fat residue $(\mathrm{g})-$ Weight of beaker $(\mathrm{g})) /$ initial sample weight $(\mathrm{g}))$

Crude Fibre $\%=($ residue $(\mathrm{g}))-($ ash $(\mathrm{g}))$

${ }^{\mathrm{b}} \mathrm{GE}$; Gross energy that was calculated using the following: $23.9 \mathrm{~kJ} \cdot \mathrm{g}^{-1}$ protein, $39.8 \mathrm{~kJ} \cdot \mathrm{g}^{-1}$ lipids and $17.6 \mathrm{~kJ} \cdot \mathrm{g}^{-1}$ carbohydrates. 
$\mathrm{SFM}=$ sunflower meal

\section{RESULTS}

Experimental diets (Table 2) had well balanced levels of $\mathrm{CP}$ and CL. However, as a consequence of SFM inclusion in the diets, the $\mathrm{CF}$ increased from $0.5 \%$ through $7.4 \%$. The amino acid profiles of the experimental diets, irrespective of SFM inclusion, were similar. The relations between essential amino acids (EAA) and nonessential amino acids (NEAA) were also similar among the experimental diets $(0.89,0.88,0.93$, and 0.89 for $0 \%, 11.7 \%, 23.5 \%$, and $34.8 \%$ SFM, respectively).

Fish survival was $88 \%(P<0.05)$ during the experimental period, and survival did not differ among groups.

During the experimental period, fish growth was homogeneous and was unaffected by SFM inclusion although this growth was not good enough due to the gradual reduction of temperature in the course of the trial.

The final weight $(\mathrm{Fw})$ fluctuated from 253 to $266 \mathrm{~g}$, and the SGR values were similar in all treatments from $0.65 \%$ per day to $0.69 \%$ per day even though the thermal coefficient of growth (TCG) levels were almost equal in all diets (1.10 to 1.16$)$ without statistical differences. Considering feed efficiency, only the feed intake ratio (FIR) was affected by SFM inclusion with fish fed $34.8 \%$ SFM having the lowest value $\left(1.52 \mathrm{~g} \cdot 100 \mathrm{~g}^{-1}\right.$ fish / day). The other parameters did not have statistical differences among treatments $(P<0.05)$ (Table 3).

In the biometric parameters, the only statistical difference was found in hepatosomatic index (HIS) with fish fed the diet containing $34.8 \%$ SFM having the lowest value (0.98). In mesenteric fat index (MFI), however, an inverse correlation was observed with SFM inclusion whereas CF and viscerosomatic index (VSI) were not affected by the treatments (Table 3 ).

In Table 4, the CP content was the only value affected by SFM with fish fed the diet containing $11.7 \%$ SFM having the lowest value (17.78) with a statistical difference. The fish fed diet with $11.7 \%$ SFM had a higher moisture level and a lower CL content when compared to other experimental groups. Furthermore, the ash content was slightly diminished when the SFM inclusion was increased $(P<0.05)$.

Table 3

Growth performance, feed efficiency, and biometric parameters of sharpsnout seabream,

Diplodus puntazzo, fed experimental diets (0\% SFM through 30\% SFM) for 162 days

\begin{tabular}{lllll}
\hline \multirow{2}{*}{ Diets } & \multicolumn{3}{c}{ Diet } \\
\cline { 2 - 5 } & $0 \mathrm{SFM}[n=4]$ & $11.7 \mathrm{SFM}[n=4]$ & $23.5 \mathrm{SFM}[n=4]$ & 34.8 SFM $[n=4]$ \\
\hline Iw $(\mathrm{g})$ & $106 \pm 0.90$ & $105 \pm 0.90$ & $105 \pm 0.90$ & $106 \pm 0.90$ \\
FW (g) & $266 \pm 9.70$ & $253 \pm 9.77$ & $265 \pm 9.49$ & $262 \pm 9.52$ \\
SGR $^{1}$ & $0.69 \pm 0.03$ & $0.65 \pm 0.03$ & $0.69 \pm 0.03$ & $0.68 \pm 0.03$ \\
WG $(\%)$ & $150 \pm 8.91$ & $142 \pm 8.91$ & $152 \pm 8.91$ & $147 \pm 8.91$ \\
FI $^{2}$ & $1.74^{\mathrm{a}} \pm 0.04$ & $1.67^{\mathrm{ab}} \pm 0.04$ & $1.65^{\mathrm{ab}} \pm 0.04$ & $1.52^{\mathrm{b}} \pm 0.04$ \\
$\mathrm{FCR}^{3}$ & $3.04 \pm 0.19$ & $2.85 \pm 0.19$ & $2.63 \pm 0.19$ & $2.56 \pm 0.19$
\end{tabular}




$\begin{array}{lllll}\mathrm{PER}^{4} & 0.78 \pm 0.03 & 0.83 \pm 0.03 & 0.91 \pm 0.03 & 0.96 \pm 0.04 \\ \mathrm{TCG}^{5} & 1.15 \pm 0.05 & 1.1 \pm 0.05 & 1.16 \pm 0.05 & 1.13 \pm 0.05 \\ \mathrm{CF}^{6} & 1.93 \pm 0.05 & 1.95 \pm 0.05 & 1.91 \pm 0.05 & 1.95 \pm 0.05 \\ \mathrm{HSI}^{7} & 1.24^{\mathrm{a}} \pm 0.47 & 1.30^{\mathrm{a}} \pm 0.50 & 1.08^{\mathrm{ab}} \pm 0.47 & 0.98^{\mathrm{b}} \pm 0.47 \\ \mathrm{VSI}^{8} & 5.3 \pm 0.26 & 5.62 \pm 0.28 & 5.69 \pm 0.26 & 5.38 \pm 0.26 \\ \mathrm{MFI}^{9} & 1.53 \pm 0.12 & 1.43 \pm 0.12 & 1.18 \pm 0.12 & 1.15 \pm 0.12\end{array}$

Each value is the mean \pm S.E.M. of data from quadruplicate groups. The data in the same row with different superscripts differ at $P<0.05$. Data on CF, HSI and MFI indices were calculated from 16 fish. Initial weight in each phase was considered as co-variables for the final weight $(\mathrm{Fw})$ and SGR.

${ }^{1}$ Specific growth rate $(\% /$ days $): \mathrm{SGR}=100 \times \ln ($ final weight $/$ initial weight $) /$ days

${ }^{2}$ Feed intake ratio $(\mathrm{g} / 100 \mathrm{~g}$ fish / days $): \mathrm{FI}=100 \times$ feed consumption $/$ average biomass $\times$ days; ${ }^{3}$ Feed conversion ratio: FCR $=$ feed offered / biomass gained; ${ }^{4}$ Protein efficiency ratio: PER = biomass gained / protein offered; ${ }^{5}$ Thermal coefficient of growth: TCG $=1000 \times[$ $\left.\mathrm{Fw}^{1 / 3}-\mathrm{Iw}^{1 / 3}\right] /\left(\mathrm{T}^{\mathrm{o}}-\right.$ minimum $\mathrm{T}^{\mathrm{o}}$ to feed $\times$ days $) ;{ }^{6}$ Condition factor: $\mathrm{CF}=100 \times$ (body weight / total length $\left.{ }^{3}\right) ;{ }^{7}$ Hepatosomatic index: HSI $=100 \times($ liver weight $/$ body weight $) ;{ }^{8}$ Viscerosomatic index: VSI $=100 \times($ visceral weight $/$ fish weight $) ;{ }^{9}$ Mesenteric fat index: $\mathrm{MFI}=100 \times($ mesenteric fat weight /body weight $]$; All weights are in $\mathrm{g}$, length in $\mathrm{cm}$; $\mathrm{Iw}=$ Initial weight

$\mathrm{Fw}=$ Final weight

Comparing the EAA composition in whole fish bodies, the only statistical difference was found in the leucine content. Similar to CP contents, the fish fed diet with $11.7 \%$ SFM had the lowest leucine level $\left(1.26 \mathrm{~g} \cdot 100 \mathrm{~g}^{-1} \mathrm{ww}\right)$ when compared to fish subjected to the other treatments. The other EEAs were present in the same quantity in whole fish bodies, except for lysine. Lysine levels were slightly reduced when the SFM inclusion was increased while there was an increase in EAA when compared to the initial fish body values (Table 4).

In corporal retention-crude protein efficiency (CPE) and gross energy efficiency (GEE), there were no statistical differences among treatments. In both retention parameters, however, there was a slight increment as vegetal meal increased. In EEA retention, there were no statistical differences among treatments although an increment in lysine and methionine contents was observed as the SFM inclusion increased. However, a fluctuation in the other EAA was observed among treatments (Table 4). 
Table 4

Proximate composition, essential-amino-acid composition, and retention of sharpsnout seabream, Diplodus puntazzo, carcasses at the end of experiment

\begin{tabular}{|c|c|c|c|c|c|c|}
\hline & \multicolumn{5}{|c|}{ Diet } \\
\hline & & Initial & 0 SFM & 11.7 SFM & $23.5 \mathrm{SFM}$ & $34.8 \mathrm{SFM}$ \\
\hline \multirow{2}{*}{\multicolumn{2}{|c|}{$\begin{array}{l}\text { Moisture }(\%) \\
\text { Crude protein }(\% \mathrm{ww})\end{array}$}} & 65.00 & $63.61 \pm 0.47$ & $64.54 \pm 0.47$ & $64.21 \pm 0.47$ & $64.58 \pm 0.47$ \\
\hline & & 17.44 & $18.41^{\mathrm{b}} \pm 0.14$ & $17.78^{\mathrm{a}} \pm 0.14$ & $18.16^{\mathrm{ab}} \pm 0.14$ & $18.15^{\mathrm{ab}} \pm 0.14$ \\
\hline \multicolumn{2}{|c|}{ Crude lipid (\%ww) } & 13.06 & $13.77 \pm 0.52$ & $13.13 \pm 0.52$ & $13.67 \pm 0.52$ & $12.61 \pm 0.52$ \\
\hline \multicolumn{2}{|c|}{ Ash $(\% w w)$} & 4.28 & $4.22 \pm 0.15$ & $4.10 \pm 0.15$ & $3.89 \pm 0.15$ & $3.98 \pm 0.15$ \\
\hline \multirow{9}{*}{ 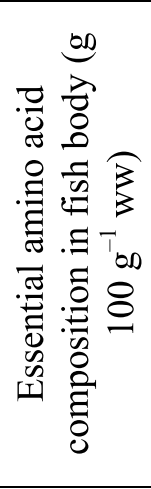 } & Histidine & 0.45 & $0.56 \pm 0.02$ & $0.49 \pm 0.02$ & $0.53 \pm 0.02$ & $0.52 \pm 0.02$ \\
\hline & Arginine & 1.49 & $1.78 \pm 0.05$ & $1.68 \pm 0.05$ & $1.69 \pm 0.05$ & $1.76 \pm 0.05$ \\
\hline & Threonine & 0.76 & $0.93 \pm 0.03$ & $0.90 \pm 0.03$ & $0.91 \pm 0.03$ & $0.93 \pm 0.03$ \\
\hline & Valine & 0.83 & $0.86 \pm 0.01$ & $0.82 \pm 0.01$ & $0.84 \pm 0.01$ & $0.83 \pm 0.01$ \\
\hline & Methionine & 0.40 & $0.47 \pm 0.01$ & $0.46 \pm 0.01$ & $0.47 \pm 0.01$ & $0.48 \pm 0.01$ \\
\hline & Lysine & 1.45 & $1.45 \pm 0.04$ & $1.41 \pm 0.04$ & $1.39 \pm 0.04$ & $1.41 \pm 0.04$ \\
\hline & Isoleucine & 0.73 & $0.70 \pm 0.01$ & $0.68 \pm 0.01$ & $0.70 \pm 0.01$ & $0.70 \pm 0.01$ \\
\hline & Leucine & 1.26 & $1.33^{\mathrm{b}} \pm 0.01$ & $1.26^{\mathrm{a}} \pm 0.01$ & $1.30^{\mathrm{ab}} \pm 0.01$ & $1.31^{\mathrm{ab}} \pm 0.01$ \\
\hline & Phenylalanine & 0.70 & $0.82 \pm 0.03$ & $0.76 \pm 0.03$ & $0.84 \pm 0.03$ & $0.83 \pm 0.03$ \\
\hline \multicolumn{2}{|c|}{ EAA/NEAA } & 0.87 & 0.90 & 0.89 & 0.92 & 0.92 \\
\hline \multirow{2}{*}{$\begin{array}{c}\text { Retention } \\
\text { values }\end{array}$} & $\mathrm{CPE}^{1}(\%)$ & & $13.60 \pm 1.12$ & $13.41 \pm 1.12$ & $14.88 \pm 1.12$ & $15.40 \pm 1.12$ \\
\hline & $\operatorname{GEE}^{2}(\%)$ & & $14.50 \pm 138$ & $14.26 \pm 1.38$ & $16.11 \pm 1.38$ & $15.71 \pm 1.38$ \\
\hline \multirow{9}{*}{ 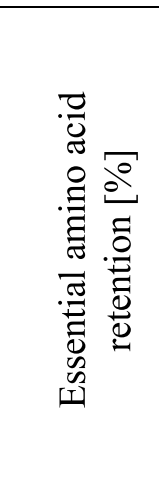 } & Histidine & & $13.99 \pm 1.61$ & $11.67 \pm 1.61$ & $14.29 \pm 1.61$ & $14.58 \pm 1.61$ \\
\hline & Arginine & & $17.50 \pm 1.50$ & $16.73 \pm 1.50$ & $17.70 \pm 2.50$ & $19.71 \pm 1.50$ \\
\hline & Threonine & & $16.29 \pm 1.69$ & $16.10 \pm 1.69$ & $17.72 \pm 1.69$ & $19.21 \pm 1.69$ \\
\hline & Valine & & $12.11 \pm 0.89$ & $11.53 \pm 0.89$ & $12.84 \pm 0.89$ & $13.01 \pm 0.89$ \\
\hline & Methionine & & $13.68 \pm 1.31$ & $14.27 \pm 1.31$ & $15.92 \pm 1.31$ & $18.03 \pm 1.31$ \\
\hline & Lysine & & $15.42 \pm 1.31$ & $15.98 \pm 1.31$ & $17.56 \pm 1.31$ & $19.52 \pm 1.31$ \\
\hline & Isoleucine & & $10.80 \pm 0.87$ & $10.98 \pm 0.87$ & $12.04 \pm 0.87$ & $12.02 \pm 0.87$ \\
\hline & Leucine & & $13.26 \pm 0.92$ & $12.77 \pm 0.92$ & $14.48 \pm 0.92$ & $15.20 \pm 0.92$ \\
\hline & Phenylalanine & & $12.48 \pm 1.35$ & $11.37 \pm 1.35$ & $13.86 \pm 1.35$ & $13.86 \pm 1.35$ \\
\hline
\end{tabular}

Values are the means \pm S.E.M $(n=4)$. The means followed by the same superscript do not differ $(\mathrm{P}<0.05$; Newman-Keuls $)$

$\mathrm{EAA}=$ Essential Amino Acids

NEAA $=$ Non essential Amino Acids

$\mathrm{CPE}=$ Crude Protein Efficiency

$\mathrm{GEE}=$ Gross Energy Efficiency

${ }^{1}$ Crude protein efficiency: CPE $(\%)=($ fish protein gain, g) x $100 /$ (protein intake, g)

${ }^{2}$ Gross energy efficiency: GEE (\%) = (fish energy gain, kJ) x $100 /$ (energy intake, kJ) 


\section{DISCUSSION}

The amino acid profile of all experimental diets was well balanced, which was similar to the profile reported by Aas et al. (2006) who included up to $36 \%$ bacterial protein meal in Salmo salar. They reported good final fish growth at the end of experimental period, attributing these results to well balanced amino acids in the experimental diets. In addition, Mai et al. (2006) indicated that lysine is the most limiting amino acid in ingredients used for production of commercial fish feeds, especially when fish meal is replaced by plant protein sources. In their study, the lysine ranged from 3.72 to 2.95 $\mathrm{g} \cdot \mathrm{kg}^{-1}$. Nevertheless, sharpsnout seabream growth rates were not as good when compared with other fattening experiments where better growth values were obtained in a shorter period of time in this species (Orban et al. 2000 and Hernández et al. 2007). One possible reason for the lower growth in our study may be explained by the temperature regime because the heat pump was broken for the final two months of the study and the temperature dropped from 27.4 to $18.1^{\circ} \mathrm{C}$.

In sharpsnout seabream, the growth parameters were not affected by SFM inclusion even with the high level of $\mathrm{CF}$ present in the experimental diets, especially in the diets with $23.5 \%$ and $34.8 \%$ SFM inclusion. It was possible that the omnivorous habits of the sharpsnout seabream enabled this species to accept a diet with up to $7 \% \mathrm{CF}$ content without affecting their final growth. Similar results were presented by Gill et al. (2006) who substituted fish meal with $33 \%$ dehulled SFM in Salmo salar although these authors only reported $3.65 \% \mathrm{CF}$ in the maximal inclusion. Mena Sellés and García García (2002) reported that one of the preferred foods of $D$. puntazzo, especially in autumn and winter, was algae. According to Lahaye (1991), algae have high fibre contents $(32.7 \%-74.6 \%$ DM). Moreover, the sharpsnout seabream gut is longer than the gut found in other species from the same genera, such as $D$. sargus and $D$. vulgaris, which may be the reason why this fish was not affected by the high fibre content in the experimental diets. Furthermore, Tramati et al. (2005) found an enzymatic pattern that is well suited to protein digestion but also has a high potential for digesting vegetal polysaccharides, which is in agreement with its omnivorous habits.

On the other hand, Sánchez Lozano et al. (2007) assayed a maximal SFM inclusion of $36 \%$ in Sparus aurata and were only able to replace fish meal with $12 \%$ as a maximal inclusion without affecting fish growth. At the same time, Olvera-Novoa et al. (2002) were only able to obtain a $20 \%$ SFM inclusion without statistical differences in Tilapia rendalli, whereas Furuya et al. (2000) recommended $14 \%$ as a maximal replacement for juvenile Nile tilapia. Regarding feed efficiency parameters, Sánchez Lozano et al. (2007) showed an increment in FIR whereas Olvera Novoa et al. (2002) reported a reduction in FI as the SFM substitution increased. Gill et al. (2006) reported similar results to our study with regard to PER.

Another important fact to consider is the solitary behaviour of sharpsnout seabream in nature, especially in mature animals [Harmelin-Vivien et al. 1995; Macpherson 1998). Monoculture conditions give rise to competition for food and space with increasing aggressiveness and a reduction in biomass (Karakatsouli et al. 2006). This competition for food and space was observed throughout this trial, which may have been an additional cause of the low growth rates achieved at the end of the experimental period.

On the other hand, an optimal amino acid profile in experimental diets may have not allowed homogeneous growth, feed conversion ratio (FCR) and PER with a reduction of FIR. Furuya et al. (2000) suggested that better fish growth and efficiency was related to a well 
balanced amino acid profile. In addition, Gill et al. (2006) did not report statistical differences in FI, but they did report an increase in FI as the SFM inclusion increased.

In biometric parameters, the reduction in HIS and MFI may have been partially caused by the $\mathrm{CF}$ in experimental diets. In addition, D. puntazzo starts its reproduction activity between October and December (Hernández 2006, Papadaki et al. 2008), and these fish may use their reserves (fat and glycogen), energy and nutrients for gonad development instead of retaining their reserves in visceral fat or liver, which may also affect fish growth in later months.

In body composition, only fish fed diet with $11.7 \%$ SFM inclusion obtained the lowest value in $\mathrm{CP}$ indicating that the vegetal meal did not affect body composition, which was similar to the results of Gill et al. (2006) and Sánchez Lozano et al. (2007) results. However, Olvera-Novoa et al. (2002) obtained statistical differences not only in CP but also in CL, ash and humidity as a consequence of SFM inclusion leading to a reduction of $\mathrm{CP}$ and an increase in $\mathrm{CL}$ and ash content.

Leucine was the only EAA that presented a statistical difference, with the lowest value presented in $11.7 \%$ SFM inclusion. According to Choo et al. (1991), the excess EAA increased feed efficiency but depressed FI, growth and protein deposition of rainbow trout. In general, SFM inclusion did not alter EAAs in carcasses, especially lysine that is known to affect fish growth and health (Mai et al. 2006), allowing a uniform fish growth among treatments. Similar results were reported by Helland and Grisdale-Helland (2006). However, Olvera-Novoa et al. (2002) and Gómez-Requeni et al. (2004) attributed growth reduction to the amino acid deficiency.

The EAA retention found in our study was low in comparison with rates reported by Helland et al. (2006) and Aas et al. (2006). This difference may be due to the high FI in relation to low final fish growth achieved at the end of the experiment. Moreover, there was a fluctuation in amino acid retention in different treatments, which may have been a response by inner fish metabolism to equilibrate EAA content in their bodies according to their needs. According to $\mathrm{Li}$ et al. (2009), amino acids have important and versatile roles in fish nutrition and metabolism. The functions of amino acids include the following: appetite stimulation (alanine, glutamate, proline, and serine); growth and development regulation (arginine, glutamine, and leucine); and dietary supplementation of amino acids (lysine, methionine, threonine, and tryptophan) to compensate for their deficiencies in plant feedstuffs. In the case of SFM, the EAA retention rates were not affected even with the highest inclusion $(34.8 \%)$.

\section{CONCLUSION}

The maximal SFM inclusion (34.8\%) did not alter growth parameters, nutritive parameters or amino acid profiles in sharpsnout seabream, even in diets with the highest $\mathrm{CF}$ content $(23.5 \%$ and $34.8 \%$ SFM). It was possible that the natural feeding habits of sharpsnout seabream enable the fish to accept a diet with a $\mathrm{CF}$ level over $7 \%$ without affecting the final weight. The low growth found in all treatments may have been attributed to several factors that should be further investigated.

\section{ACKNOWLEDGEMENT}

This research was supported by grants from the Planes Nacionales de Acuicultura (JACUMAR).

\section{REFERENCES}

Aas T.S., Hatlen B., Grisdale-Helland B., Terjesen B.F., Bakke-McKellep A.M., Helland S.J. 2006. Effects of diets containing a bacterial protein meal on growth and feed utilisation in ranbow trout (Oncorhynchus 
mykiss). Aquacutlure 261 (1): 357-368. DOI: 10.1016/j.aquaculture.2006.07.033

Ahmad T., Aslam Z., Rasool S. 2004. Reducing fiber content of sunflower oil meal through treatment of enzymes produced from Arachnoitus sp. Animal Science Journal $\mathbf{7 5}$ (3): 231-235. DOI: $10.1111 / \mathrm{j} .1740-$ 0929.2004.00181.x

Anonymous 1990. Official methods of analysis. Association of Official Analytical Chemists (AOAC). Arlington, VA, USA.

Bosch L., Alegría A., Farré R. 2006. Application of the 6-aminoquinolyl- $\mathrm{N}$ hydroxysuccinimidyl carbamate (AQC), reagent to the RP-HPLC determination of amino acids in infant foods. Journal of Chromatography B 831 (1-2): 176-183. DOI: 10.1016/j.jchromb.2005.12.002

Chatzifotis S., Esteban A.G., Divanach P. 2006. Fishmeal replacements by alfalfa protein concentrate in sharp snout sea bream Diplodus puntazzo. Fisheries Science 72 (6): 13131315. DOI: $\quad 10.1111 / \mathrm{j} .1444-$ 2906.2006.01290.x

Choo P.-S., Smith T.K., Cho C.Y., Ferguson H.W. 1991. Dietary excesses of leucine influence growth and body composition of rainbow trout. Journal of Nutrition 121 (12): 1932-1939.

Francis G., Makker H.P.S., Becker K. 2001. Antinutritional factors present in plant-derived alternate fish feed ingredients and their effects in fish. Aquaculture 199 (3-4): 197-227. DOI: 10.1016/S0044-8486(01)00526-9

Furuya V.R.B., Furuya W.M., Hayashi C., Soares C.M. 2000. Niveles de Inclusión de Harina de Girasol en la Alimentación de la Tilapia del Nilo (Oreochromis niloticus), en etapa juvenil (Inclusion levels of sunflower meal in diets for juvenile Nile tilapia (Oreochromis niloticus)),. Zootecnia Tropical 18 (1): 91-106.

Gandhi A.P., Jha K., Gupta V. 2008. Technical paper studies on the production of defatted sunflower meal with low polyphenol and phytate contents and its nutritional profile. ASEAN Food Journal 15 (1): 97-100.

Gill N., Higgs D.A., Skura B.J., Rowshandeli M., Dosanjh B.S., Mann J., Gannam A.L. 2006. Nutritive value of partially dehulled and extruded sunflower meal for post-smolt Atlantic salmon (Salmo salar L.) in sea water. Aquaculture Research 37 (13): 1348-1359. DOI: $10.1111 /$ j.1365-2109.2006.01567.x

Gómez-Requeni P., Mingarro M., CalduchGiner J.A., Médale F., Martin S.A.M., Houlihan D.F., Kaushik S., Pérez-Sánchez J. 2004. Protein growth performance, amino acid utilisation and somatotropic axis responsiveness to fish meal replacement by plant protein sources in gilthead sea bream (Sparus aurata). Aquaculture 232 (1-4): 493510. DOI: $10.1016 / \mathrm{S} 0044-8486(03) 00532-5$

Harmelin-Vivien M.L., Harmelin J.G., Leboulleux V. $1995 . \quad$ Microhabitat requirements for settlement of juvenile sparid fishes on Mediterranean rocky shores. Hydrobiologia 300/3001: 309 - 320.

Helland S.J., Grisdale-Helland B. 2006. Replacement of fish meal with wheat gluten in diets for Atlantic halibut (Hippoglossus hippoglossus): Effect on whole-body amino acid concentrations. Aquaculture 261 (4): 1363-1370.

DOI: 10.1016/j.aquaculture.2006.09.025

Hernández M.D. 2006. El cultivo de una especie omnívora: el sargo picudo (Diplodus puntazzo). [The production of an omnivorous specie: sharpsnout seabream (Diplodus puntazzo)] Pp. 99-114. In: Zamora S., Martínez F.J., Cruz V. (eds.) Acuicultura III: Cultivo y Alimentación de peces. Universidad Internacional del Mar, Murcia, Spain.

Hernández M.D., Martínez F.J., Jover M., García García B. 2007. Effects of partial replacement of fish meal by soybean meal in sharpsnout seabream (Diplodus puntazzo) diet. Aquaculture 263 (1-4): 159-167. DOI: 10.1016/j.aquaculture.2006.07.040

Karakatsouli N., Papafotiou P., Papoutsoglou S.E., 2006. Mono- and duoculture of juvenile sharpsnout seabream Diplodus puntazzo (Cetti) and gilthead seabream Sparus aurata L. in a recirculated water system. Aquaculture Research 37 (16): 1654-1661. DOI: 10.1111/j.1365-2109.2006.01612.x

Lahaye M. 1991. Marine algae as sources of fibres: Determination of soluble and insoluble dietary fibre contents in some 'sea vegetables'. Journal of the Science of Food and $\begin{array}{llll}\text { Agriculture } \quad 54 & \text { (4): } & 587-594 .\end{array}$ DOI: $10.1002 /$ jsfa.2740540410

Li P., Mai K., Trushenski J., Wu G. 2009. New developments in fish amino acid nutrition: Towards functional and environmentally oriented aquafeeds. Amino Acids 37 (1): 4353. DOI: $10.1007 / \mathrm{s} 00726-008-0171-1$

Macpherson E. 1998. Ontogenetic shifts in habitat use and aggregation in juvenile sparid fishes. Journal of Experimental Marine Biology and Ecology 220 (1): 127-150. DOI: 10.1016/S0022-0981(97)00086-5

Mai K., Zhang L., Ai Q., Duan Q., Zhang C., Li H., Wan J., Liufu Z. 2006. Dietary lysine requirement of juvenile Japanese seabass, Lateolabrax japonicus. Aquaculture 258 (14): 535-542. DOI: 10.1016/j.aquaculture.2006.04.043

Maina J.G., Beames R.M., Higgs D., Mbugua P.N., Iwama G., Kisia S.M. 2003. Partial 
replacement of fishmeal with sunflower cake and corn oil in diets for tilapia Oreochromis niloticus (Linn): Effect on whole body fatty acids. Aquaculture Research 34 (8): 601-608. DOI: $10.1046 /$ j.1365-2109.2003.00848.x

Martínez C.A. 1984. Advances in the substitution of fish meal and soybean meal by sunflower meal in diets of rainbow trout (Salmo gairdneri L.). Anales Del Instituto De Ciencias Del Mar Y Limnología Univ. Nacional. Autónoma México 13 (2): 345-350. http://biblioweb.dgsca.unam.mx/cienciasdelm ar/instituto/19862/articulo235.html

Mena Sellés C., García García B. 2002. Importancia de la proteína vegetal en la dieta natural de poblaciones salvajes de Sargo picudo Diplodus puntazzo (Cetti, 1777); sus implicaciones en el cultivo intensivo.(Importance of vegetable protein in natural diet of wild population of sharpsnout seabream (Diplodus puntazzo); and its implication in intensive culture AquaTIC: Revista Electrónica de Acuicultura. Tecnología e Investigación en Castellano (17): (there is no page number) http://www.revistaaquatic.com/aquatic/html/ar t1705/sargo.htm

Olvera-Novoa M., Olivera-Castillo L. MartínezPalacios C.A. 2002 Sunflower seed meal as a protein source in diets for Tilapia rendalli (Boulanger 1896) fingerlings. Aquaculture Research 33 (3): 223-229. DOI: 10.1046/j.1365-2109.2002.00666.x

Orban E., Di Lena G., Ricelli A., Paoletti F., Casini I., Gambelli L., Caproni R. 2000. Quality characteristics of sharpsnout sea bream (Diplodus puntazzo) from different intensive rearing systems. Food Chemistry 70 (1): 27-32. DOI: 10.1016/S09567135(99)00112-7

Papadaki M., Papadopoulou M., Siggelaki I., Mylonas C.C. 2008. Egg and sperm production and quality of sharpsnout sea bream (Diplodus puntazzo) in captivity. Aquaculture 276 (1-4): 187-197. DOI: 10.1016/j.aquaculture.2008.01.033

Rondán M., Hernández M.D., Egea M.A., García B., Jover M., Rueda F.M., Martínez F.J. 2004. Effects of fishmeal replacement with soybean meal as protein source, and protein replacement with carbohydrates as an alternative energy source on sharpsnout sea bream, Diplodus puntazzo, fatty acid profile. Aquaculture Research 35 (13): 1220-1227. DOI: $10.1111 / \mathrm{j} .1365-2109.2004 .01130 . \mathrm{x}$

Sánchez Lozano N.B., Tomás Vidal A., Martínez-Llorens S., Nogales Mérida S., Espert Blanco J., Moñino López A., Pla Torres M., Jover Cerdá M. 2007. Growth and economic profit of gilthead sea bream (Sparus aurata L.) fed sunflower meal. Aquaculture 272 (1-4): 528-534. DOI: 10.1016/j.aquaculture.2007.07.221

Sanz A., Morales A.E., De la Higuera M., Gardenete G. 1994. Sunflower meal compared with soybean meals as partial substitutes for fish meal in rainbow trout (Oncorhynchus mykiss) diets: protein and energy utilization. Aquaculture 128 (3-4): 287-300. DOI: 10.1016/0044-8486(94)903182

Snedecor G., Cochran W. 1971. Statistical methods. The Iowa State University Press, Ames, IA, USA.

Tramati C., Savona B., Mazzola A. 2005. A study of the pattern of digestive enzimes in Diplodus puntazzo (Cetti, 1777)(Osteichhyes, Sparidae): evidence for the definition of nutritional protocols. Aquaculture international 13, 89-95. DOI: $10.1007 / \mathrm{s} 10499$ 004-9028-0

Received: 2 April 2009

Accepted: 1 June 2010

Published electronically: 00 March 2011 


\section{CAPÍTULO 7}

Gradual fish oil substitution by soybean oil and Diplodus puntazzojuveniles' performance. Fatty acid profile and liver histology.

Enviado a: Journal of World Aquaculture Society. 



\title{
Gradual fish oil substitution by soybean oil and Diplodus puntazzo juveniles'
}

\author{
performance. Fatty acid profile and liver histology.
}

Nogales-Mérida, S., Tomás Vidal, A., Martinez-Llorens, S., Moya V.J., Jover Cerdá, M. Institute of Animal Science and Technology. Aquaculture and Biodiversity Group. Polytechnic University of Valencia.

Correspondence: Silvia Nogales Mérida, Polytechnic University of Valencia. Camino de Vera, 14. 46071Valencia (Spain). silvianogales@hotmail.com. Tel: 34-96-3877007; Fax 34-96-3877439

\begin{abstract}
The present study was performed to determine the percentage of soybean oil on the performance of growth, fatty acids and liver histology of sharpsnout sea bream. It was done to determinate the adequate soybean oil inclusion without reduction fish fillet quality and alters fish health. Four isonitrogenous (41\%) and isolipid (21\%) experimental diets were formulated containing $0 \%, 25 \%, 50 \%$ and $75 \%$ soybean oil in experimental diets. One hundred and twenty fish of initial of approximately $35 \mathrm{~g}$ average weight were randomly allocated into 12 cages connected to a closed recirculation system. Fish were hand-fed to apparent satiation for 84 days. Increasing the level of soybean oil had no significant effects on growth and feed efficiency parameters. Biometrics, body composition and protein and energy efficiency were not affected by fish oil replacement. Muscle and liver fatty acids reflected fish oil substitution. Although fish fed until 50\% soybean oil did not present significant difference in highly unsaturated fatty acids content. The thrombogenic index reduced while soybean oil inclusion increased in sharpsnout sea bream's diets. Moreover, histology did not show statistical differences among treatments.
\end{abstract}

According to a market survey on carnivorous aquaculture species, gilthead sea bream (Sparus aurata), sea bass (Dicentrarchus labrax), turbot (Psetta maxima), salmon (Salmo salar) and trout (Oncorhynchus mykiss) are the most consumed by the Spanish population. But there are some species such as sharpsnout sea bream (Diplodus puntazzo) of interest in aquaculture production, as they could be an alternative in aquaculture diversification (Garcia Garcia et al. 2007) thanks to its omnivorous habits. This nutritional habit could be advantage to obtain a reduction in fish meal and fish oil consumption to improve fish production sustainability.

As it is known, fish oil (FO) has been used as a basic component of fish nutrition in aquaculture. In the last decade, there has been investigating the presence of dioxin and dioxin-like polychlorinated biphenyls in fish oil and how the replacement of fish oil by vegetable oils affect (Lundebye et al. 2004; Bell et al. 2005; Turchini et al. 2009). On the other hand, Soybean oil (SO) has been widely used to feed marine species as well as continental fish with different results ranging from similar growth to fish fed with FO to deleterious effects due to this vegetable oil inclusion, especially reported in Salmonidae. Negative effects are being attributed to high levels of plant oil inclusion in fish nutrition previously associated with degeneration in histological tissue structure (Alexis 1997), resulting in an accumulation of large lipid vacuoles in the enterocytes and hepatocytes (Olsen et al. 2003; Caballero et al. 2002 and Ruyter et al. 2006). Perhaps due to selective fish accumulation of 18:2n-6 and 18:1n-9 (Ruyter et al. 2006). Wassef et al. (2007) also commented that gilthead sea bream fed with a mix of vegetable oils (palm oil, soybean oil, cottonseed oil, sunflower oil and linseed oil) presented hepatocytes with nuclear migration and numerous varying sized lipid vacuoles, compared with fish fed on FO. In sharpsnout sea bream juveniles were not reported hepatic alteration with partial FO substitution by pork lard (Nogales-Mérida et al. 2011). 
Besides, the replacement of FO with SO affects the fatty acid (FA) composition, especially highly unsaturated fatty acids (HUFA), as marine fish are unable to synthesize these FA from linolenic (LNA) and linoleic acid, (LA) (Turchini et al. 2009; Wassef et al. 2007; Piedecausa et al. 2007). Although Díaz-López et al. (2009) commented that FO replacement is possible when HUFA are present in the diet at sufficient quantities to meet the EFA requirement of the fish. The EFA deficiency has been associated not only to fish death or poor growth, but also an increased sensitivity to stressful situations (Glencross 2009), that could cause health problem and fish death.

Therefore, the aim of this study was to determine the optimum percentage of FO replacement by SO on sharpsnout sea bream to prevent health problem and define the ideal percentage of SO to improve flesh quality. This objective could be achieved by comparing the fatty acid profile of fish fillets and how this vegetable oil could alter liver histology at the end of the experimental period.

\section{Material and Methods.}

One hundred and twenty fish were employed with initial average weight (34.8 \pm 7 g), fed with four experimental diets (Table 1) that were partially replaced by soybean oil; $0,25,50$ and $75 \%$ as a maximum percentage to be tested. Experimental diets were almost isoproteic $41 \%$ crude protein (CP) and isolipidic $21 \%$ crude lipid (CL). Three replicates were performed per treatment. In this experiment, $24 \%$ of sunflower meal was included in all experimental diets because fish growth and feed efficiency were not altered by the inclusion of this vegetable meal (Nogales-Mérida et al. 2010).

Table 1. Experimental diets: formulation and proximal analysis.

\begin{tabular}{|c|c|c|c|c|}
\hline Ingredients $\left(\mathrm{g} \mathrm{kg}^{-1}\right)$ & $0 \%$ & $25 \%$ & $50 \%$ & $75 \%$ \\
\hline Fish meal $(5-02-000)^{\mathrm{a}}$ & 454 & 454 & 454 & 454 \\
\hline Sunflower meal $(5-04-739)^{\mathrm{b}}$ & 235 & 235 & 235 & 235 \\
\hline Wheat $(4-05-268)^{c}$ & 94 & 94 & 94 & 94 \\
\hline Dextrin (4-08-023) & 50 & 50 & 50 & 50 \\
\hline Soybean Oil (4-07-983) & 0 & 50 & 100 & 150 \\
\hline Fish oil (7-08-048) & 157 & 107 & 57 & 7 \\
\hline Multivitamin mix & 6.3 & 6.3 & 6.3 & 6.3 \\
\hline Mineral mix ${ }^{\mathrm{e}}$ & 2.2 & 2.2 & 2.2 & 2.2 \\
\hline Vitamin C & 1.5 & 1.5 & 1.5 & 1.5 \\
\hline \multicolumn{5}{|c|}{ Proximate analysis (\% Dry matter) } \\
\hline Dry matter & 93.31 & 92.97 & 93.61 & 92.29 \\
\hline Crude Protein (CP) & 41.51 & 40.98 & 41.64 & 41.48 \\
\hline Crude Lipid (CL) & 20.62 & 20.12 & 21.77 & 21.41 \\
\hline Ash & 10.95 & 10.40 & 10.87 & 10.44 \\
\hline Crude Fibre (CF) & 4.85 & 4.79 & 4.86 & 4.85 \\
\hline \multicolumn{5}{|l|}{ Values calculated } \\
\hline Nitrogen free extract $(\mathrm{NFE})^{\mathrm{f}}$ & 22.07 & 23.71 & 20.86 & 21.82 \\
\hline $\mathrm{GE}(\mathrm{Mj} / \mathrm{kg})^{\mathrm{g}}$ & 22.01 & 21.97 & 22.29 & 22.28 \\
\hline $\mathrm{CP} / \mathrm{GE}(\mathrm{g} / \mathrm{MJ})$ & 18.86 & 18.66 & 18.68 & 18.62 \\
\hline
\end{tabular}

${ }^{\mathrm{a}}$ Fish meal: DM: 93.6\%; CP: 72.9\%; CL: 8.7\%; Ash: 17.0\%; GE: $20.89 \mathrm{Mj} / \mathrm{kg}$

${ }^{\mathrm{b}}$ Sunflower meal: DM: 91.4\%; CP: 38.3\%; CL: 2.2\%; CF: 21\%; Ash: 8.0\% NFE: 30.5\%; GE: 15.39

$\mathrm{Mj} / \mathrm{kg}$

${ }^{c}$ Wheat: DM: 88.5\%; CP: 9.1\%; CF: 3.2\%; Ash: 1.5\%; NFE: $84.0 \%$, GE: $17.79 \mathrm{Mj} / \mathrm{kg}$

${ }^{\mathrm{d}}$ Multivitamin mix (values are $\mathrm{g} \mathrm{kg}^{-1}$ except those in parentheses): premix, 25; choline, 10; DL- $\infty$ tocopherol, 5; ascorbic acid, 5; $\left(\mathrm{PO}_{4}\right)_{2} \mathrm{Ca}_{3}$ 5. Premix composition: retinol acetate, $100000 \mathrm{IU} / \mathrm{kg}$ calcipherol 500IU/kg; DL- $\infty$ - tocopherol, 10; menadione sodium bisulphite, 0.8; thiamine hydrochloride, 2.3; riboflavin, 2.3; pyridoxine hydrochloride, 15; cyanocobalamin, 25; nicotinamide, 15; 
pantothenic acid, 6; folic acid, 0.65; biotin, 0.07; ascorbic acid, 75; inositol, 15; betaine, 100; polypeptides. 12. (Dibaq-Diproteg)

${ }^{\mathrm{e}} \mathrm{Zn}, 5$; Se, 0.02; I 0.5; Fe, 0.2; CuO, 15; Mg, 5.75; Co, 0.02. (Dibaq-Diproteg)

${ }^{\mathrm{f}} \mathrm{NFE}(\%)=100-\% \mathrm{CP}-\% \mathrm{CL}-\%$ Ash-\%CF.

${ }^{\mathrm{g}}$ Gross energy: Calculated using: $23.9 \mathrm{~kJ} / \mathrm{g}$ proteins, $39.8 \mathrm{~kJ} \mathrm{~g}^{-1}$ lipids and $17.6 \mathrm{~kJ} / \mathrm{g}$ carbohydrates

Fish were brought from University of Valencia, Spain with an average weight of 15 g. A month before the trial started, these fish were fed with a Microbaq 15 commercial diet (CP 50\%; CL 20\%; Nitrogen free extract (NFE) 13\% and Ash 10\%) (Dibaq Diproteg, Segovia, Spain). Ten fish per cage were placed at the beginning of the experiment. Three cages were inserted into cylinder-conical tanks of $750 \mathrm{~L}$ capacity. A total of four cylindrical fibreglass tanks, set up in a marine water recirculation system with a capacity of $30 \mathrm{~m}^{3}$, were used in this trial.

Table 2. Fatty acids composition of ingredients and experimental diets expressed in $\%$ of FAME identified in samples.

\begin{tabular}{|c|c|c|c|c|c|c|}
\hline & \multicolumn{2}{|c|}{ Ingredients } & \multicolumn{4}{|c|}{ Experimental diets } \\
\hline & FO & $\mathrm{SO}$ & $0 \%$ & $25 \%$ & $50 \%$ & $75 \%$ \\
\hline $\mathrm{C} 14: 0$ & 4.64 & nd & 4.98 & 3.61 & 2.48 & 1.57 \\
\hline $\mathrm{C} 15: 0$ & 0.51 & nd & 0.58 & 0.41 & 0.24 & 0.00 \\
\hline $\mathrm{C} 16: 0$ & 15.68 & 10.96 & 18.20 & 16.18 & 14.62 & 14.50 \\
\hline C18:0 & 3.76 & 3.20 & 4.58 & 4.29 & 4.08 & 4.36 \\
\hline $\mathrm{C} 20: 0$ & 0.24 & nd & 0.26 & nd & nd & nd \\
\hline $\mathrm{C} 22: 0$ & 0.17 & nd & 0.24 & 0.25 & 0.34 & 0.47 \\
\hline $\mathrm{C} 24: 0$ & 0.07 & nd & 0.13 & 0.14 & 0.16 & 0.19 \\
\hline$S F A$ & 24.84 & 14.16 & 28.70 & 24.89 & 21.91 & 21.08 \\
\hline C16:1 & 5.79 & nd & 5.91 & 4.31 & 3.02 & 1.74 \\
\hline C18:1n-7 & 4.32 & nd & 4.07 & 3.61 & 3.31 & 3.05 \\
\hline $\mathrm{C} 18: \ln 9 \mathrm{c}$ & 19.29 & 25.03 & 15.78 & 17.05 & 19.17 & 20.32 \\
\hline $\mathrm{C} 20: 1$ & 4.85 & nd & 3.89 & 2.61 & 1.54 & 0.49 \\
\hline $\mathrm{C} 22: \ln 9$ & 5.08 & nd & 3.75 & 2.30 & 1.45 & 0.44 \\
\hline $\mathrm{C} 24: 1$ & 0.82 & nd & 0.64 & 0.53 & 0.42 & 0.20 \\
\hline$M U F A$ & 40.16 & 25.03 & 34.04 & 30.41 & 28.91 & 26.24 \\
\hline C18:2n6 (LA) & 5.74 & 54.60 & 6.38 & 17.87 & 30.47 & 40.63 \\
\hline C18:3n3 (LNA) & 2.15 & 6.15 & 1.49 & 2.56 & 3.63 & 4.42 \\
\hline $\mathrm{C} 18: 3 \mathrm{n} 6$ & 0.19 & nd & 0.16 & 0.14 & 0.11 & 0.0 \\
\hline $\mathrm{C} 20: 2 \mathrm{n} 6$ & 2.07 & nd & 1.98 & 0.71 & 0.95 & 0.49 \\
\hline $\mathrm{C} 20: 3 \mathrm{n} 3$ & 1.20 & nd & 0.22 & 0.06 & 0.09 & 0.00 \\
\hline $\mathrm{C} 20: 3 \mathrm{n} 6$ & 0.20 & nd & 0.17 & 0.08 & 0.07 & 0.04 \\
\hline C20:4n6 (ARA) & 0.94 & nd & 1.22 & 0.90 & 0.68 & 0.40 \\
\hline $\mathrm{C} 20: 5 \mathrm{n} 3$ & 7.87 & nd & 8.89 & 6.90 & 5.18 & 3.05 \\
\hline $\mathrm{C} 22: 2$ & 0.98 & nd & 0.74 & 0.55 & 0.32 & 0.15 \\
\hline C22:5n3 (EPA) & 2.25 & nd & 2.05 & 1.51 & 1.05 & 0.54 \\
\hline C22:6n3 (DHA) & 10.44 & nd & 12.77 & 9.18 & 6.17 & 2.69 \\
\hline$P U F A$ & 34.02 & 60.75 & 36.05 & 40.46 & 48.73 & 52.41 \\
\hline n-3 HUFA & 20.56 & 0 & 23.70 & 17.60 & 12.40 & 6.27 \\
\hline n3 & 23.90 & 6.15 & 25.41 & 20.21 & 16.13 & 10.69 \\
\hline n6 & 9.14 & 54.60 & 9.90 & 19.70 & 32.29 & 41.56 \\
\hline $\mathrm{n} 3 / \mathrm{n} 6$ & 2.61 & 0.11 & 2.57 & 1.03 & 0.50 & 0.26 \\
\hline EPA/DHA & 0.75 & 0 & 0.70 & 0.75 & 0.84 & 1.13 \\
\hline n6/n3 & 0.38 & 8.88 & 0.39 & 0.97 & 2.00 & 3.89 \\
\hline
\end{tabular}

nd: not detected.

PUFA $=(\mathrm{C} 18: 2 \mathrm{n} 6)+(\mathrm{C} 18: 3 \mathrm{n} 3)+(\mathrm{C} 20: 4 \mathrm{n} 6)+(\mathrm{C} 20: 5 \mathrm{n} 3)+(\mathrm{C} 22: 6 \mathrm{n} 3)$

$\Omega_{3}$ HUFA $=(\mathrm{C} 22: 5 \mathrm{n} 3)+(\mathrm{C} 20: 5 \mathrm{n} 3)+(\mathrm{C} 22: 6 \mathrm{n} 3)$

All ingredients of experimental diets were ground, mixed, and then passed through an extruder (CLEXTRAL BC-45, Firmity, St. Etienne, France) and four rod- 
shaped extruded diets of two $\mathrm{mm}$ in diameter were prepared under processing conditions of $0.63 \mathrm{~g}$ screw speed, $110 \mathrm{C}$ and $30-40 \mathrm{~atm}$.

Fish were fed by hand to apparent satiation six days/week for 12 weeks. They were fed two times a day $(0900$ and $1400 \mathrm{~h})$. The trial was divided into three periods; in each period, fish were weighed one by one to determine growth and efficiency parameters. Fish were reared in a sea water recirculation system with almost constant temperature $(22.8 \pm 1.3 \mathrm{C})$. Dissolved oxygen was $6.5 \pm 0.3 \mathrm{mg} \mathrm{L}^{-1}$, salinity $27.7 \pm 2.2$ $\mathrm{g} / \mathrm{L}, \mathrm{NO}_{2}{ }^{-} 0.2 \pm 0.1 \mathrm{mg} / \mathrm{L}, \mathrm{NO}_{3}{ }^{-} 31.1 \pm 12.8 \mathrm{mg} / \mathrm{L}$ and $\mathrm{pH}$ ranged from 6 to 7 . Photoperiod was natural and all tanks had similar light conditions.

At the outset, only ten fish and at the end five fish per basket were sacrificed to determine fish composition and fatty acid modifications in fish liver and muscle caused by FO substitution. It was collected nine livers per treatment to histological analysis.

Chemical samples of raw material, diets and fish carcass were analysed according to the Association of Official Analytical chemists (AOAC 1990) procedures: dry matter (105 $\mathrm{C}$ to constant weight), ash (incinerated at $550 \mathrm{C}$ to constant weight) and crude protein ( $\mathrm{N}$ x 6.25) were determined by Kjeltec 2300 Auto Analyser, (Tecator, Höganas, Sweden) and lipid was determined using a Foss Tecator Soxtec 1043 extraction unit using diethyl ether as a solvent. All analyses were performed in triplicate.

Fatty acid methyl esters (FAME) of total lipids were prepared directly as previously described O'Fallon, et al. (2007). FAME was done with raw material, experimental diets and six subsamples of liver and muscles from each treatment. FAME analysis was performed in a Focus Gas Chromatograph (Thermo, Milan, Italy) equipped with a split/splitless injector and a flame ionisation detector. Separation of methyl esters was performed in a fused silica capillary column $\mathrm{SP}^{\mathrm{TM}} 2560$ (Supelco, PA, USA) (100 m x $0.25 \mathrm{~mm} \times 0.2 \mu \mathrm{m}$ film thickness). The carrier gas was Helium at a linear velocity of $20 \mathrm{~cm} / \mathrm{sec}$. The samples were injected with a split ratio of $1 / 100$. The initial oven temperature was set at $140 \mathrm{C}$ held for five minutes and increased to 240 at 4 $\mathrm{C} / \mathrm{min}$ and finally maintained at that temperature for $30 \mathrm{~min}$. Both, detector and injector temperatures were set at $260 \mathrm{C}$. The individual fatty acids were identified by comparing their retention times with standards of fatty acid methyl esters supplied by Supelco (PA, USA).

Two fish per tank were sacrificed to collect and fix their livers in phosphate buffered formalin (4\% $\mathrm{pH} 7.4)$ and then transfer them to $70 \%$ ethanol for storage until processing. All formalin fixed tissues were routinely dehydrated in ethanol, equilibrating in Ultraclear ${ }^{\mathrm{TM}}$ and embedded in paraffin according to standard histological techniques. Longitudinal sections (approximately $5 \mu \mathrm{m}$ thick) were cut and stained with haematoxylin and eosin (HE). Processing of the tissues took place at the Histology section of the Animal Science Department of the Polytechnic University of Valencia (Spain). Blinded histological examination was performed by light microscopy (Nikon Phase Contrast 090 Dry, Japan, MJVS). Tissue morphology was evaluated according to McFadzen et al. (1997) criteria in addition to quantification of hepatocytes to observe possible alterations revealed through differences in the hepatocyte condition or hepatic cell morphology. The quantification of hepatocytes was done per area $\left(125.000 \mu \mathrm{m}^{2}\right)$. 
Table 3. Effect of partial replacement of fish oil by soybean oil on growth and nutritive parameters of sharpsnout sea bream at the end of the trial.

\begin{tabular}{lccccc}
\hline \multicolumn{1}{c}{ Treatments } & $0 \%$ & $25 \%$ & $50 \%$ & $75 \%$ & SEM \\
\hline IBW $(\mathrm{g})$ & 32.3 & 35.3 & 35.0 & 36.2 & \pm 2.74 \\
$\mathrm{FBW}(\mathrm{g})$ & 108.4 & 103.7 & 104.6 & 105.7 & \pm 2.05 \\
$\% \mathrm{BWG}$ & 221.8 & 200.2 & 201.9 & 200.5 & \pm 10.22 \\
$\mathrm{SGR}^{1}\left(\%\right.$ day $\left.^{-1}\right)$ & 1.36 & 1.31 & 1.32 & 1.33 & \pm 0.02 \\
$\mathrm{TGC}^{2}$ & 1.88 & 1.79 & 1.80 & 1.82 & \pm 0.04 \\
$\mathrm{FCR}^{3}$ & 2.17 & 2.11 & 2.28 & 2.28 & \pm 0.12 \\
$\mathrm{FI}^{4}$ & 2.69 & 2.50 & 2.66 & 2.64 & \pm 0.13 \\
$\mathrm{PER}^{5}$ & 1.19 & 1.25 & 1.13 & 1.15 & \pm 0.06
\end{tabular}

Different superscript letters denote significant differences within row $(\mathrm{P}<0.05)$. All values are means of triplicate baskets $(\mathrm{n}=3)$.

Initial weight in each phase was considerer as covariable for live weight and SGR.

${ }^{1}$ Specific growth rate $(\% /$ day $), S G R=100 \times \ln$ (final weight $/$ initial weight $) /$ days

${ }^{2}$ Thermal Growth Coefficient, TGC $=1000 *\left[\mathrm{Fw}^{1 / 3}-\mathrm{Iw}^{1 / 3}\right] /\left(\right.$ effective $\left.\mathrm{T}^{\mathrm{o}}\right)$

${ }^{3}$ Feed Conversion ratio, FCR $=$ feed offered $(\mathrm{g}) /$ Biomass gain $(\mathrm{g})$

${ }^{4}$ Feed Intake ratio (g $100 \mathrm{~g} /$ fish/day), FI $=100 \mathrm{x}$ feed consumption $(\mathrm{g}) /$ average biomass $(\mathrm{g}) \mathrm{x}$ days

${ }^{5}$ Protein efficiency ratio, PER $=$ Biomass gain $(\mathrm{g}) /$ protein offered $(\mathrm{g})$

Growth data and nutritive parameters were treated using multifactor analysis of variance (ANOVA), introducing the initial live weight as covariate (Snedecor and Cochran 1971). Newman-Keuls test was used to assess specific differences among diets at 0.05 significant levels (Stat graphics, Statistical Graphics System, Version Plus 5.1, Herndon, Virginia, USA). Hepatocyte quantification was analysed by One-Way ANOVA and analysis by McFadzen et al. (1997) criterion was done using a cross tabulation and Chi-Square contrast $\left(\mathrm{X}^{2}\right)$ methodology.

\section{Results}

Table 2 shows the fatty acids of experimental diets. A gradual increment in Linoleic Acid (LA) and Linolenic Acid (LNA) can be observed, and in consequence the sums of the polyunsaturated fatty acids (PUFA) also rose as the SO inclusion was increased $(36 \%, 40.5 \%, 48.7 \%, 52.4 \%$ respectively). However, the highly unsaturated fatty acid ( $\Omega_{3}$ HUFA) values decreased as SO inclusion was increased from $23.70 \%$ to $6.27 \%$. A decreasing percentage in DHA, EPA and the $\mathrm{n} 3 / \mathrm{n} 6$ ratio was observed as a consequence of replacing FO by SO. As a result, saturate fatty acids (SFA) diminished while SO inclusion increased.

The gradual SO inclusion combined with $24 \%$ of sunflower meal in experimental diets did not alter final fish growth over the 84 days that the experiment lasted. Fish survival was high, an average of $96 \%$ and without statistical differences among treatments. 
Table 4. Effect of soybean oil level on biometric parameters, whole body composition and nutrient retention of sharpsnout sea bream.

\begin{tabular}{lcccccc}
\hline & Initial & $0 \%$ & $25 \%$ & $50 \%$ & $75 \%$ & SEM \\
\hline $\mathrm{CF}^{\mathrm{a}}$ & & 2.18 & 2.00 & 2.37 & 2.12 & 0.15 \\
$\mathrm{HSI}^{\mathrm{b}}$ & & 1.44 & 1.38 & 1.44 & 1.41 & 0.09 \\
$\mathrm{MF}^{\mathrm{c}}$ & & 2.61 & 2.20 & 2.72 & 2.40 & 0.26 \\
$\mathrm{VSI}^{\mathrm{d}}$ & & 9.75 & 9.02 & 9.55 & 9.34 & 0.57 \\
$\mathrm{DP}^{\mathrm{e}}$ & & 76.00 & 76.83 & 76.49 & 77.33 & 0.73 \\
Moisture (\%) & 70.52 & 63.56 & 63.82 & 63.91 & 63.09 & 0.48 \\
$\mathrm{CP}(\% \mathrm{wm})$ & 15.83 & 16.99 & 16.59 & 16.94 & 16.78 & 0.30 \\
$\mathrm{CL}(\% \mathrm{wm})$ & 9.54 & 14.53 & 15.21 & 14.89 & 15.11 & 0.49 \\
Ash (\% wm) & 4.10 & 3.92 & 4.14 & 3.97 & 4.04 & 0.13 \\
Calculated values & & & & & & \\
GE (MJ/kg) & 7.58 & 9.85 & 10.02 & 9.97 & 10.02 & 0.24 \\
CPE (\%) & & 20.97 & 21.11 & 20.00 & 19.98 & 1.51 \\
GEE (\%) & & 24.52 & 26.03 & 23.96 & 24.32 & 1.78 \\
\hline
\end{tabular}

Different superscript letters denote significant differences within row $(\mathrm{P}<0.05)$. All values are means of triplicate baskets $(n=3)$.

${ }^{\mathrm{a}}$ Condition Factor, $\mathrm{CF}=\left[\right.$ body weight $(\mathrm{g}) /$ total length $\left.(\mathrm{cm})^{3}\right] \times 100$.

${ }^{\mathrm{b}}$ Hepatosomatic index, HSI $=[$ liver weight $(\mathrm{g}) /$ body weight $(\mathrm{g})] \mathrm{x} 100$.

${ }^{\mathrm{c}}$ Mesenteric fat index, MFI $=[$ mesenteric fat weight $(\mathrm{g}) /$ body weight $(\mathrm{g})] \times 100$.

${ }^{\mathrm{d}}$ Viscerosomatic index, VSI $=100 \mathrm{x}$ [visceral weight $(\mathrm{g}) /$ fish weight $\left.(\mathrm{g})\right]$

${ }^{\mathrm{e}}$ Dress out percentage, DP $=100 \mathrm{x}$ [total fish weight $(\mathrm{g})$ - visceral weight $(\mathrm{g})$-head weight $\left.(\mathrm{g})\right] /$ fish weight $(\mathrm{g})$

${ }^{\mathrm{f}}$ Gross energy, GE $=$ Calculated using: $23.9 \mathrm{~kJ} / \mathrm{g}$ proteins, $39.8 \mathrm{~kJ} / \mathrm{g}$ lipids and $17.6 \mathrm{~kJ} / \mathrm{g}$ carbohydrates

${ }^{\mathrm{g}}$ Crude protein efficiency, CPE (\%) = (Increment of protein corporally $\left.(\mathrm{g})\right) \times 100 /$ (ingestion protein, $\left.(\mathrm{g})\right)$

${ }^{\mathrm{h}}$ Grow energy efficiency, GEE $(\%)=(\%)$ (Increment of energy corporally, ( kJ)) x $100 /$ (ingestion de energy $(\mathrm{kJ}))$

Growth parameters and feed efficiency are observed in Table 3. An average BWG of $206 \%$ was achieved at the end of the trial. Feed efficiency did not exhibit statistical differences in diets. In feed efficiency, the FCR values were from 2.1 to $2.3 \%$. The final body weight fluctuated between experimental diets from 104 to $108 \mathrm{~g}$ and the SGR was between 1.36 and $1.31 \%$ /day $(\mathrm{P}<0.05)$.

Table 4 shows the biometric and body parameters measured at the end of the trial. There were no statistical differences in any value; similar results were obtained in Crude protein efficiency (CPE) and Gross Energy efficiency.

Fatty acids (FA) of fish fillet and fish liver are presented in Table 5. These FA reflected SO inclusion in experimental diets. Fish muscle presented statistical differences in SFA and fish fed $75 \%$ had the lowest value $(28.6 \%)$. In monounsaturated fatty acids (MUFA), there were also differences, with fish fed the $75 \%$ diet presenting the lowest value $(26.8 \%)$. Most relevant FA for fish growth and health were also affected by FO substitution, reporting statistical differences. In LA, the highest value obtained was with $75 \%$ diet $(27.4 \%)$ compared with $0 \%$ diet $(7.1 \%)$. In LNA, the highest value was reported with fish fed the $75 \%$ diet $(2.5 \%)$. ARA was the only essential fatty acids (EFA) that did not present statistical differences among treatments. In EPA, the lowest values were obtained with the $75 \%$ and $50 \%$ diets $(4.9 \%$ and $5.7 \%)$ compared with $0 \%$ and $25 \%$ diets $(7.6 \%$ and $6.9 \%)$. In DHA, similar results were observed, with fish fed $0 \%$ and $25 \%$ diet presenting the highest percentage $(13.8 \%$ and $14.1 \%)$ and in PUFA, the highest value was observed in $75 \%(50.5 \%)$. Aterogenic index diminished while SO inclusion increased. But, trombogenic index were similar in all treatments $(\mathrm{P}<0.05)$. 
In fish liver (Table 5), the values were similar to those obtained in fish muscle. There were no statistical differences in SFA, MUFA and polyunsaturated fatty acids (PUFA) content. HUFA values presented statistical differences; fish fed with $50 \%$ and $75 \%$ SO inclusion presented the lowest value. In LA, the lowest value was obtained with $0 \% \operatorname{diet}(4.8 \%)$. In LNA, the lowest was also reported with the $0 \% \operatorname{diet}(0.7 \%)$. In contrast, ARA, EPA and DHA were the lowest values achieved with the $75 \% \operatorname{diet}(0.7 \%$ ARA; $2.1 \%$ EPA and 5.1\% in DHA, respectively) $(\mathrm{P}<0.05)$.

If the percentage of fatty acids obtained in fish muscle and liver are related to the percentage of fatty acids of their experimental diets, some interesting data can be observed, as shown in Fig. 2: In fig. 2a, statistical differences were observed in EPA and DHA, with fish fed $75 \%$ diet presenting the highest ratio $(1.6 \%$ and $3.5 \%$ respectively), as the graph showed the percentage of these EFA rising as the SO inclusion was increased. Similar results were observed in ARA ratio without statistical differences. On the contrary, in LA, fish fed the control diet reported the highest value $(1.1 \%)$ compared with the other treatments. In fig. $2 b$, no statistical differences were observed, but the same tendency reported in fish muscle was observed in fish liver with the same EFA $(\mathrm{P}<0.05)$.

Hepatocyte quantification and hepatic cells morphological status are reported in Table 6. Histological analysis of hepatic cells (liver nuclei; liver hepatocyte cytoplasm, hepatocyte vacuolation and pancreatic acinar cells) did not exhibit any statistical differences. Hepatocyte quantification did not present statistical differences among treatments. Regular shaped hepatocytes with some lipid accumulation in the cytoplasm and, in most cases, central allocated nuclei were observed in fish fed with different experimental diets (Fig. 3).

\section{Discussion}

The inclusion of sunflower meal in sharpsnout sea bream diet, combined with an increased percentage of SO was considered, previous good results achieved by NogalesMerida et al. (2010), and also to provide this omnivorous species with a certain quantity of fibre that the fish found in nature with algae consumption (Sala and Ballesteros 1997; Costa and Cataudella, 2007).

As it was expected experimental diets presented a gradual decreasing percentage of essential fatty acids for marine species. In the maximum substitution ARA diminished a $67 \%$ and EPA and DHA diminished a $66 \%$ and $79 \%$ respectively (Table 2). But if these results are compared with Piedecausa et al. (2007) diet's these EFA diminished from 84 to $86 \%$. This reduction did not affect fish growth, but it apparently diminished fish survival, especially fish fed with linseed oil (34\%). They attributed to an increment of stress conditions that induced bacterial infection. That was not the case of this research.

Fish growth and feed efficiency results were not affected by soybean oil inclusion. Similar results were obtained by Piedecausa et al. (2007). At the same time, different SO inclusion did not alter any biometric parameter in sharpsnout sea bream. But the complete FO substitution by SO increased the HSI, (Piedecausa et al. 2007), maybe due to the deficiency in EFA that Tacon (1992) described in some marine and continental species. 
Table 5. Fatty acids profile of liver and fillets of sharpsnout sea bream fed the experimental diets.

\begin{tabular}{|c|c|c|c|c|c|c|c|c|c|c|}
\hline & \multicolumn{5}{|c|}{ Fatty acids in liver } & \multicolumn{5}{|c|}{ Fatty acids in fillet (muscle) } \\
\hline & $0 \%$ & $25 \%$ & $50 \%$ & $75 \%$ & SEM & $0 \%$ & $25 \%$ & $50 \%$ & $75 \%$ & SEM \\
\hline C14:0 & $2.5^{\mathrm{c}}$ & $2.0^{\mathrm{bc}}$ & $1.9^{\mathrm{ab}}$ & $1.4^{\mathrm{a}}$ & 0.1 & $2.8^{\mathrm{b}}$ & $2.2^{\mathrm{b}}$ & $2.2^{\mathrm{b}}$ & $1.4^{\mathrm{a}}$ & 0.2 \\
\hline C15:0. & $0.4^{\mathrm{b}}$ & $0.3^{\mathrm{ab}}$ & $0.2^{\mathrm{ab}}$ & $0.2^{\mathrm{a}}$ & 0.0 & 0.3 & 0.2 & 0.2 & 0.8 & 0.0 \\
\hline $\mathrm{C} 16: 0$ & 22.2 & 22.2 & 21.6 & 22.2 & 1.0 & $20.7^{\mathrm{c}}$ & $19.2^{\mathrm{bc}}$ & $18.0^{\mathrm{ab}}$ & $16.4^{\mathrm{a}}$ & 0.6 \\
\hline C18:0. & 6.0 & 6.6 & 6.3 & 6.1 & 0.4 & 4.5 & 4.7 & 4.5 & 4.6 & 0.3 \\
\hline C20:0 & 0.2 & 0.2 & 0.2 & 0.2 & 0.0 & 0.1 & 0.1 & 0.1 & 0.1 & 0.0 \\
\hline $\mathrm{C} 22: 0$ & 0.1 & 0.1 & 0.1 & 0.1 & 0.0 & 0.0 & 0.1 & 0.1 & 0.1 & 0.0 \\
\hline $\mathrm{C} 24: 0$. & 0.00 & 0.1 & 0.1 & 0.1 & 0.0 & 0.0 & 0.0 & 0.0 & 0.0 & 0.0 \\
\hline$S F A$ & 31.4 & 31.6 & 30.5 & 30.4 & 1.3 & $28.6^{c}$ & $26.7^{b c}$ & $25.1^{b}$ & $22.7^{a}$ & 0.8 \\
\hline C15:1. & - & - & - & - & & 0.0 & 0.0 & $\operatorname{tr}$ & 0.0 & 0.0 \\
\hline C16:1. & $4.4^{\mathrm{c}}$ & $3.4^{\mathrm{b}}$ & $3.1^{\mathrm{b}}$ & $2.5^{\mathrm{a}}$ & 0.1 & $4.9^{\mathrm{c}}$ & $4.1^{\mathrm{b}}$ & $3.9^{\mathrm{b}}$ & $2.5^{\mathrm{a}}$ & 0.2 \\
\hline C18:1(n9)t. & $0.3^{\mathrm{c}}$ & $0.2^{\mathrm{bc}}$ & $0.2^{\mathrm{b}}$ & $0.1^{\mathrm{a}}$ & 0.0 & 0.3 & 0.2 & 0.2 & 0.4 & 0.1 \\
\hline C18:1(n9) & 23.4 & 22.7 & 24.8 & 24.6 & 1.6 & 19.7 & 19.3 & 19.7 & 19.5 & 0.8 \\
\hline $\mathrm{C} 18: 1(\mathrm{n} 7)$ & $5.7^{\mathrm{c}}$ & $4.8^{\mathrm{b}}$ & $4.6^{\mathrm{b}}$ & $3.9^{\mathrm{a}}$ & 0.2 & $4.5^{\mathrm{c}}$ & $4.0^{\mathrm{b}}$ & $3.6^{\mathrm{ab}}$ & $3.2^{\mathrm{a}}$ & 0.2 \\
\hline C20:1(n9) & $3.8^{\mathrm{c}}$ & $3.1^{\mathrm{b}}$ & $2.6^{\mathrm{b}}$ & $2.0^{\mathrm{a}}$ & 0.2 & $2.0^{\mathrm{c}}$ & $1.7^{\mathrm{bc}}$ & $1.6^{\mathrm{b}}$ & $1.0^{\mathrm{a}}$ & 0.1 \\
\hline $\mathrm{C} 22: 1$ (n9) & $1.1^{\mathrm{b}}$ & $0.4^{\mathrm{a}}$ & $0.4^{\mathrm{a}}$ & $0.2^{\mathrm{a}}$ & 0.1 & 0.6 & 0.6 & 0.4 & 0.1 & 0.1 \\
\hline $\mathrm{C} 24: 1$ (n9) & 0.3 & 0.2 & 0.2 & 0.2 & 0.0 & $0.2^{\mathrm{ab}}$ & $0.2^{\mathrm{b}}$ & $0.2^{\mathrm{ab}}$ & $0.1^{\mathrm{a}}$ & 0.0 \\
\hline$M U F A$ & 39.0 & 34.9 & 35.9 & 33.7 & 1.9 & $32.2^{b}$ & $30.2^{a b}$ & $29.6^{a b}$ & $26.8^{a}$ & 1.1 \\
\hline $\mathrm{C} 18: 2(\mathrm{n} 6) \mathrm{t}$ & - & 1.9 & 0.0 & - & 0.9 & 0.0 & 0.0 & $\operatorname{tr}$ & $\operatorname{tr}$ & 0.0 \\
\hline C18:2(n6)c (LA) & $4.8^{\mathrm{a}}$ & $10.0^{\mathrm{b}}$ & $15.6^{\mathrm{c}}$ & $21.7^{\mathrm{d}}$ & 1.3 & $7.1^{\mathrm{a}}$ & $13.9^{\mathrm{b}}$ & $19.8^{\mathrm{c}}$ & $27.4^{\mathrm{d}}$ & 0.7 \\
\hline $\mathrm{C} 18: 3(\mathrm{n} 6)$ & 0.2 & 0.9 & 0.3 & 0.4 & 0.3 & $0.1^{\mathrm{a}}$ & $0.2^{\mathrm{b}}$ & $0.3^{\mathrm{c}}$ & $0.3^{\mathrm{c}}$ & 0.0 \\
\hline C18:3(n3) (LNA) & $0.7^{\mathrm{a}}$ & $1.2^{\mathrm{b}}$ & $1.3^{\mathrm{b}}$ & $1.7^{\mathrm{c}}$ & 0.1 & $1.0^{\mathrm{a}}$ & $1.6^{\mathrm{b}}$ & $2.1^{\mathrm{c}}$ & $2.5^{\mathrm{d}}$ & 0.1 \\
\hline $\mathrm{C} 20: 2(\mathrm{n} 6)$ & $0.8^{\mathrm{a}}$ & $1.1^{\mathrm{b}}$ & $1.2^{\mathrm{b}}$ & $1.3^{\mathrm{b}}$ & 0.1 & 0.9 & 0.8 & 0.9 & 1.0 & 0.1 \\
\hline $\mathrm{C} 20: 3(\mathrm{n} 6)$ & $0.3^{\mathrm{a}}$ & $0.5^{\mathrm{b}}$ & $0.5^{\mathrm{b}}$ & $0.8^{\mathrm{c}}$ & 0.1 & $0.3^{\mathrm{a}}$ & $0.4^{\mathrm{a}}$ & $0.4^{\mathrm{a}}$ & $0.7^{\mathrm{b}}$ & 0.0 \\
\hline $\mathrm{C} 20: 3(\mathrm{n} 3)$ & 0.3 & 0.3 & 0.3 & 0.2 & 0.0 & 0.1 & 0.1 & 0.4 & 0.1 & 0.1 \\
\hline C20:4(n6) (ARA) & $1.4^{\mathrm{b}}$ & $1.3^{\mathrm{b}}$ & $1.1^{\mathrm{ab}}$ & $0.7^{\mathrm{a}}$ & 0.1 & 1.6 & 1.6 & 1.3 & 1.2 & 0.1 \\
\hline $\mathrm{C} 22: 2$ & $0.9^{\mathrm{b}}$ & $0.7^{\mathrm{b}}$ & $0.7^{\mathrm{b}}$ & $0.4^{\mathrm{a}}$ & 0.0 & 0.8 & 0.6 & 0.7 & 0.5 & 0.1 \\
\hline $\mathrm{C} 20: 5(\mathrm{n} 3)(\mathrm{EPA})$ & $4.4^{\mathrm{c}}$ & $3.6^{\mathrm{bc}}$ & $2.9^{\mathrm{ab}}$ & $2.1^{\mathrm{a}}$ & 0.3 & $7.6^{\mathrm{c}}$ & $6.9^{\mathrm{bc}}$ & $5.7^{\mathrm{ab}}$ & $4.9^{\mathrm{a}}$ & 0.4 \\
\hline $\mathrm{C} 22: 5(\mathrm{n} 3)$ & $3.4^{\mathrm{b}}$ & $2.7^{\mathrm{b}}$ & $1.9^{\mathrm{a}}$ & $1.4^{\mathrm{a}}$ & 0.3 & 5.9 & 2.8 & 2.5 & 2.2 & 1.4 \\
\hline $\mathrm{C} 22: 6(\mathrm{n} 3)$ (DHA) & $12.4^{\mathrm{b}}$ & $10.4^{\mathrm{b}}$ & $7.8^{\mathrm{ab}}$ & $5.1^{\mathrm{a}}$ & 1.4 & $13.8^{\mathrm{b}}$ & $14.1^{\mathrm{b}}$ & $11.2^{\mathrm{ab}}$ & $9.5^{\mathrm{a}}$ & 0.9 \\
\hline PUFA & 29.6 & 33.5 & 33.6 & 35.9 & 2.5 & $39.2^{a}$ & $43.1^{b}$ & $45.2^{b}$ & $50.5^{c}$ & 1.2 \\
\hline$n-3 H U F A$ & $20.2^{c}$ & $16.6^{b c}$ & $12.5^{a b}$ & $8.6^{a}$ & 1.8 & $27.3^{b}$ & $23.9^{b}$ & $19.4^{a}$ & $16.6^{a}$ & 1.2 \\
\hline n3 & $21.3^{\mathrm{c}}$ & $18.0^{\mathrm{bc}}$ & $14.1^{\mathrm{ab}}$ & $10.5^{\mathrm{a}}$ & 1.9 & $28.4^{\mathrm{b}}$ & $25.6^{\mathrm{b}}$ & $21.9^{\mathrm{a}}$ & $19.3^{\mathrm{a}}$ & 1.2 \\
\hline n6 & $7.5^{\mathrm{a}}$ & $14.8^{\mathrm{b}}$ & $18.8^{\mathrm{c}}$ & $25.0^{\mathrm{d}}$ & 1.0 & $10.0^{\mathrm{a}}$ & $16.9^{\mathrm{b}}$ & $22.6^{\mathrm{c}}$ & $30.6^{d}$ & 0.7 \\
\hline $\mathrm{n} 3 / \mathrm{n} 6$ & $2.8^{\mathrm{d}}$ & $1.2^{\mathrm{c}}$ & $0.8^{\mathrm{b}}$ & $0.4^{\mathrm{a}}$ & 0.1 & $2.9^{\mathrm{c}}$ & $1.5^{\mathrm{b}}$ & $1.0^{\mathrm{a}}$ & $0.6^{\mathrm{a}}$ & 0.1 \\
\hline EPA/DHA & 0.4 & 0.4 & 0.4 & 0.4 & 0.0 & $0.6^{\mathrm{b}}$ & $0.5^{\mathrm{a}}$ & $0.5^{\mathrm{ab}}$ & $0.5^{\mathrm{ab}}$ & 0.0 \\
\hline $\mathrm{n} 6 / \mathrm{n} 3$ & $0.3^{\mathrm{a}}$ & $0.9^{\mathrm{ab}}$ & $1.6^{\mathrm{b}}$ & $2.6^{\mathrm{c}}$ & 0.2 & $0.4^{\mathrm{a}}$ & $0.7^{\mathrm{b}}$ & $1.0^{\mathrm{c}}$ & $1.6^{\mathrm{d}}$ & 0.1 \\
\hline$I A^{a}$ & 0.30 & 0.33 & 0.39 & 0.40 & 0.03 & 0.23 & 0.23 & 0.24 & 0.23 & 0.01 \\
\hline$I T^{\mathrm{b}}$ & 0.33 & 0.31 & 0.29 & 0.27 & 0.02 & $0.29^{a}$ & $0.24^{b}$ & $0.22^{b}$ & $0.17^{c}$ & 0.01 \\
\hline
\end{tabular}

Different superscript letters denote significant differences within row $(\mathrm{P}<0.05)$. Four replicate per experimental baskets were analysed.

a,b,c,d Different letters denoted statistical differences among treatments.

${ }^{a}$ Index of atherogenicity: (IA) $=\left[\left(a^{*} 12: 0\right)+(b * 14: 0)+\left(c^{*} 16: 0\right)\right] /\left[d^{*}(\right.$ PUFA $n-6+n-3)+e^{*}($ MUFA $)+f$

*(MUFA-18:1)]

${ }^{\mathrm{b}}$ Index of thrombogenicity $(\mathrm{IT})=\mathrm{IT}=[\mathrm{g} *(14: 0+16: 0+(18: 0)] /[(\mathrm{h} * \mathrm{MUFA})+\mathrm{i} *($ MUFA-18:1) $+(\mathrm{m} * \mathrm{n}-$

$6)+(n * n-3)+(n-3 / n-6)]$

(Where a, c, d, e, f=1, b=4, g=1, h, i, m=0.5 and $n=3$ ).

In addition, whole body composition was similar in all treatments, showing that partial FO substitution did not affect any parameter analysed and coinciding with Piedecausa et al. (2007), except for ash content, for which these authors reported a reduction in fish fed vegetable oil diets. Similar results were noted by Martínez-Llorens et al. (2007) and Fountoulaki et al. (2009). Likewise, CPE and GEE were not affected by FO substitution, in agreement with the results of Piedecausa et al. (2007) and Martínez-Llorens et al. (2007). Moreover, Turchini et al. (2009) indicated that the use of vegetable oil did not significantly affect growth performance and feed utilisation in omnivorous and herbivorous fish. However, with a few exceptions, most feeding trials conducted to date have been relatively short-term and the long-term effects of dietary 
inclusion of vegetable oil and animal fats remain to be elucidated, particularly with regard to the effects on the fish immune system.
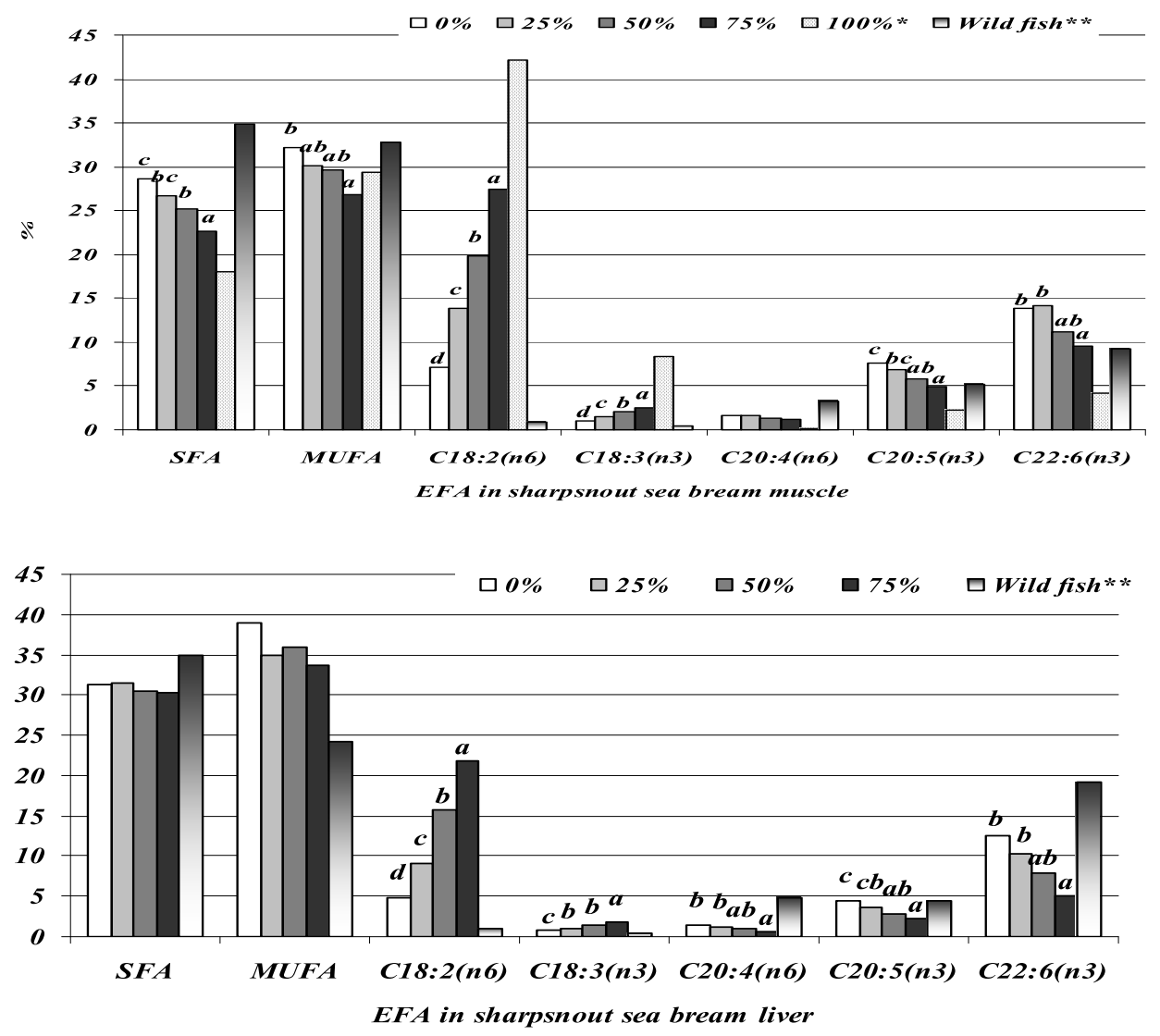

Figure 1. Fatty acids in muscle and liver of $\underline{D}$. puntazzo fed with the experimental diets at the end of the trial and comparing with $100 \%$ SO and wild sharpsnout sea bream in the muscle. Values expressed in percentage of FAME identified in samples. Data are the means $(n=6) \pm$ SEM. Different letters denote statistical differences $\mathrm{P}<0.05$.

$* 100 \%$ SO (Piedecausa et al., 2007)

** Wild fish (Rueda et al., 2001)

As Shearer (2001) and Turchini et al. (2009) reported, fatty acid profile of fish reflects the fatty acid profile of their diet. And in this case, fatty acids of muscle and liver of fish fed with different experimental diets exhibited statistical differences as a logical consequence of oil replacement (Table 5). But, only fish fed $75 \%$ SO diet exhibited significant differences in DHA and up to $50 \%$ SO presented significant differences in EPA. In ARA there were no differences among treatments, these percentage showed that fish fed $50 \%$ SO inclusion did not alter its $\Omega_{3}$ and $\Omega_{6}$. If these HUFA contents are related to values obtained by Piedecausa et al. (2007) and Almaida Pagan et al. (2007), they presented a high reduction, more than $60 \%$ of ARA, EPA and DHA content in comparison to sharpsnout sea bream fed FO diets. And they concluded that sharpsnout sea bream presents a typical "marine" pattern and it cannot completely compensate for dietary oil composition differences. Besides, Peng et al. (2008) obtained coincident results, limiting the inclusion of vegetable oil at levels above $80 \%$ in black sea bream diets according to growth values achieved. Comparing the $\Omega_{3}$ values there is more than $40 \%$ of reduction y EPA and DHA. In gilthead sea bream, Izquierdo et al. (2003) and Benedito-Palos et al. (2009) found more than $45 \%$ reduction in HUFA content in diets with 60 and $66 \%$ of FO substitution by SO. Comparing the facts commented above and the results obtained in the present trial it could assume that 
sharpsnout sea bream has certain ability to make better use of vegetable oils than other carnivorous sea breams.

Table 6. Hepatocyte quantification and morphological evaluation of sharpsnout sea bream liver at the end of the experimental period.

\begin{tabular}{cccccc}
\hline & $0 \%$ & $25 \%$ & $50 \%$ & $75 \%$ & SEM \\
\hline Hepatocytes $^{\mathrm{a}}$ & 768 & 1013 & 828 & 833 & 72.05 \\
\hline Liver nuclei & $\begin{array}{c}\text { Liver hepatocyte } \\
\text { cytoplasm }\end{array}$ & $\begin{array}{c}\text { Hepatocyte } \\
\text { vacuolation }\end{array}$ & $\begin{array}{c}\text { Pancreatic acinar } \\
\text { cells }\end{array}$
\end{tabular}

\begin{tabular}{lcccccccccccc} 
& 1 & 2 & 3 & 1 & 2 & 3 & 1 & 2 & 3 & 1 & 2 & 3 \\
\hline $0 \%$ & 6 & 0 & - & 6 & - & - & 5 & 1 & - & 6 & - & - \\
$25 \%$ & 5 & 1 & - & 5 & 1 & - & 4 & 2 & - & 6 & - & - \\
$50 \%$ & 6 & - & - & 5 & 1 & - & 2 & 4 & - & 6 & - & - \\
$75 \%$ & 5 & 1 & - & 2 & 4 & - & 2 & 4 & - & 6 & - & - \\
P-value & 0.5708 & & & 0.0776 & & & 0.2881 & & & 0.3975 & &
\end{tabular}

1 (Healthy) 2. (Intermediate) 3 (Degraded)

Different superscript letters denote significant differences within row $(\mathrm{P}<0.05)$.

Six replicates per treatment were analysed.

${ }^{\mathrm{a}}$ Hepatocytes / $125000 \mu \mathrm{m}^{2}$

Besides, comparing the EFA of experimental diets and the fatty acids in liver and fillet of D. puntazzo (Fig. 2), could lead to think that this species could have a certain capacity to elongate and de-saturate from precursors (C18:2n-6 and C18:3n-3) to compensate the diminishing of highly unsaturated fatty acids (C20:4n-6, C20:5n-3 and C22:6n-3) in their diets. Similar results were commented by Benedito-Palos et al. (2008) in S. aurata fed with a mix of vegetable oils. However, this compensation does not seem to be enough in fish fed with $75 \%$ SO diet to reach the values reported by those fed with 0, 25 and 50\% diets, perhaps due to development and physiological stage and their environment (Turchini et al. 2009). On the contrary, Martino et al. (2002), who tested different animal and vegetable oils in an omnivorous continental species, reported a higher content of these EFA with special emphasis on $\Omega_{3}$ HUFA in (Pesudoplatystoma coruscans) spotted surubim's liver fed with soybean and linseed oil diets, thanks to the capacity of these species to bio-convert $\mathrm{C}_{18}$ PUFA to longer and more unsaturated fatty acids (Turchini et al. 2009).

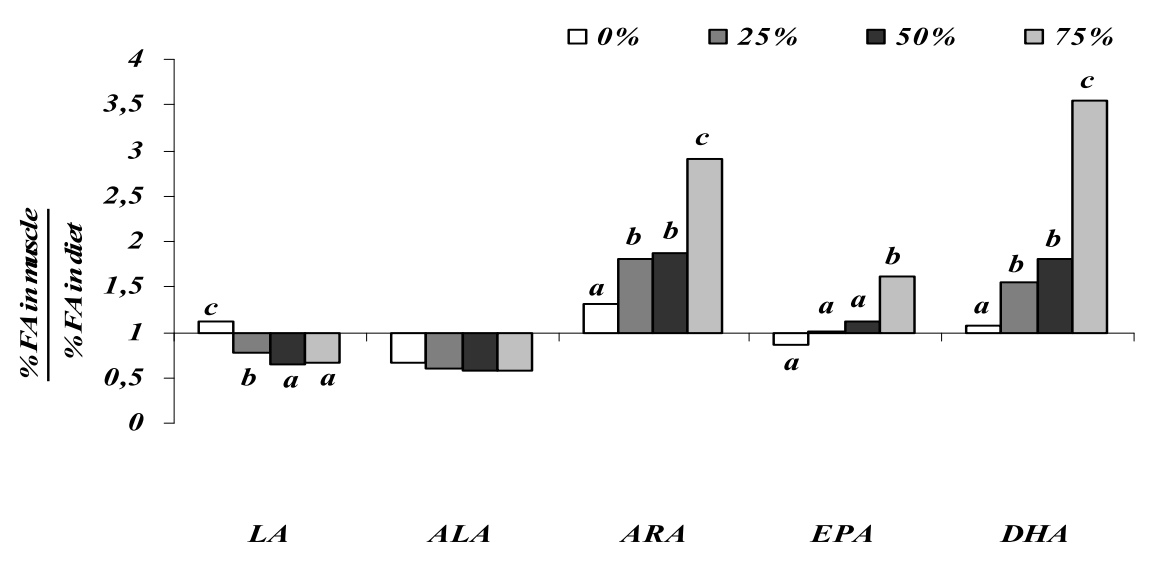




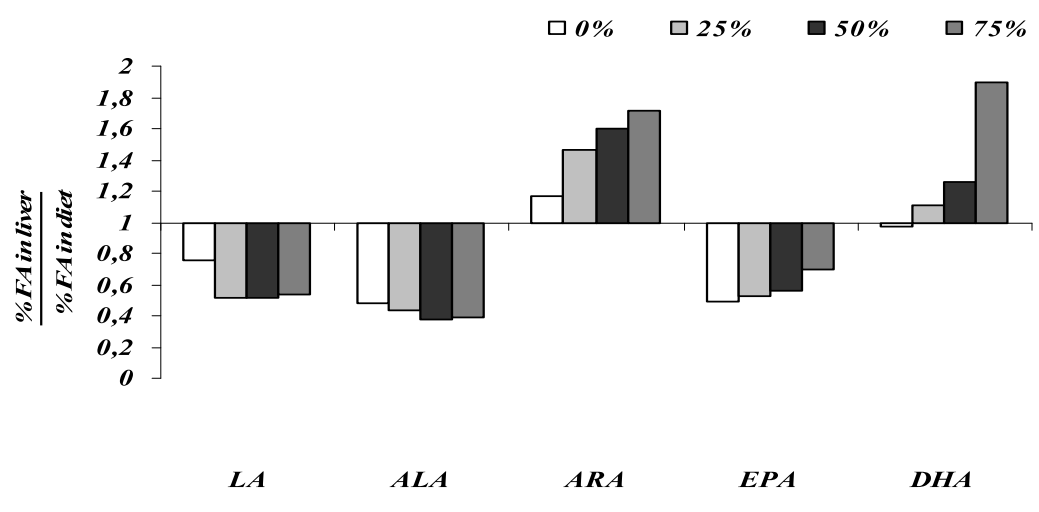

Figure 2. The relation between percentage of fatty acids in muscle (a) and liver (b) of sharpsnout sea bream and experimental diets; Linoleic acids (LA C18: 2n6); Linolenic acids (LNA C18: 3n3), Eicosapentaenoic acids (EPA C20: 5n3) and docosahexaenoic acids (DHA C22: 6n3). Data are the means $(\mathrm{n}=6) \pm$ SEM. Different letters denote statistical differences $\mathrm{P}<0.05$.

In addition, the comparison of EFA of wild sharpsnout sea bream and experimental animals showed that fillets of wild fish (Rueda et al. 2001) presented higher values of SFA, MUFA, ARA and lower content of EPA, DHA, LA, LNA as it is shown in fig. 1. This figure also showed a great reduction in SFA and HUFA and a considerable increment in LA and LNA in fish fed 100\% SO (Piedecausa et al. 2007) in comparison with the maximum substitution. Although in liver FA of wild sharpsnout sea bream was observed a higher content of SFA, ARA, EPA and DHA and lower values of MUFA, LA and LNA in comparison to experimental fish, including $0 \% \mathrm{SO}$. Although the values obtained by Rueda et al. (2001) in wild sharpsnout sea bream could be affected by the period of the year of animal sampling. Mena Selles and Garcia Garcia (2002) reported that stomach content of wild sharpsnout sea bream vary along the year, according to the abundance of animal or vegetable meal. Finally, fillet of $D$. puntazzo fed even with $75 \%$ SO diet could be consider as healthier as wild sharpsnout sea bream fillets.

The Atherogenicity Index (IA) and the Trombogenicity Index (TI) were lower than those reported by Rueda et al. (2001). These indexes are used to determinate if a food could induce to some coronary or brain diseases. These values should not exceed from five, and in sharpsnout sea bream fillet fed with SO does not reach 0.4. This showed that $D$. puntazzo fillets are healthy for human consumption.

Soybean oil substitution had no apparent effect on sharpsnout sea bream liver morphology. Hepatocytes exhibited similar morphology in all treatments; perhaps no alteration was detected because fish liver according to Roberts (1981) seems to be diffuse and in most cases if there is an alteration it is usually focal that might be why no alteration were detected. The most common cause of liver degeneration is fatty acid oxidation inducing fat infiltration in hepatocytes. (Roberts 1981). Caballero et al. (2002) also reported homogeneous sized hepatocytes with some vacuolated cytoplasm in trout fed with a 50\% SO diet, which did not differ too much from the control diet in relation to other vegetable oils. Figueiredo Silva et al. (2005) reported a normal histological pattern in sea bass, despite the marked hepatocellular vacuolation, corresponding to naturally high lipid content, although hepatocytes displayed little or no glycogen content in sea bass fed with $50 \% \mathrm{SO}$. The lipid fraction of fish tissues is most significantly affected by the nature of dietary lipids (vegetable oils versus fish oils), with triglycerides (neutral lipids) being much more affected than phospholipids (polar 
lipids). One possible reason why livers of sharpsnout sea bream fed with different SO substitution did not present high amounts of lipid droplets in hepatocytes could be due to temperature, as Ruyter et al. (2006) reported that trout fed at $12^{\circ} \mathrm{C}$ presented less lipid accumulation in enterocytes than fish fed at $5^{\circ} \mathrm{C}$, while another possible reason could be fish habits.

However, fish liver shows both intra- and inter-specific variability. Such differences from one species to another and from one individual to another could be correlated with the amount of energy that they store (glycogen and/or lipid), depending on the specific metabolic activities related to seasonal changes, temperature, sexual maturity and nutritional status (Bruslé and Gonzales i Anadon, 1996).
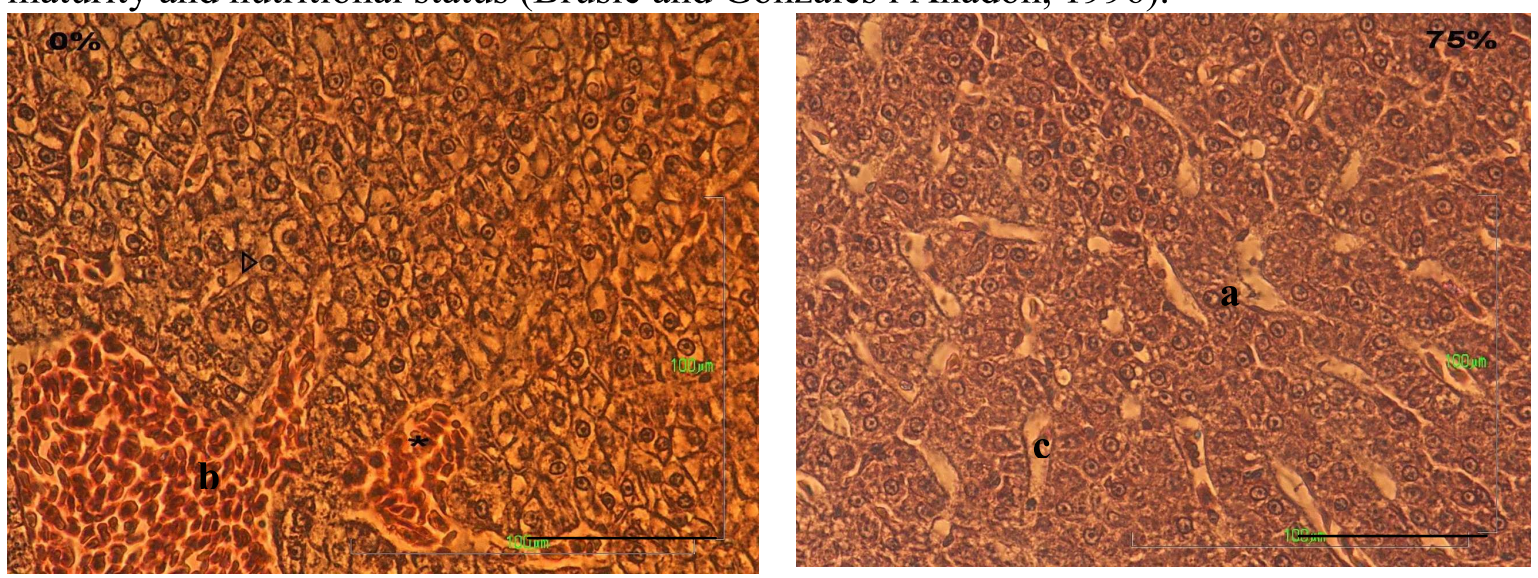

Figure 3. Livers from fish fed the control diet $(0 \%)$ and the maximum substitution $(75 \%)$. a) hepatocytes,

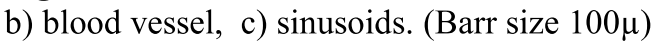

Sharpsnout sea bream juveniles could accept FO replacement by soybean oil up to $75 \%$ for a period of 84 days without affecting growth, feed efficiency parameters biometric and body composition. However, there were no statistical differences in fish fillet fed with 50\% SO in ARA, DHA and EPA contents. These essential fatty acids are known to prevent cardiovascular and neurological diseases. Moreover, the values obtained in this trial showed that until $75 \%$ of soybean oil inclusion could present similar values than wild $D$. puntazzo. This trial also showed that liver morphology was not affected by this vegetable oil. Perhaps, fish production would be not only based on growth versus profit, but also consider fish health and fillet quality, so the data obtained in this trial could take into account as a preliminary result.

\section{Acknowledgments}

This study was supported by grants from the "Planes Nacionales de Acuicultura (JACUMAR)" and Consellería de Agricultura Pesca y Alimentación, Valencia, Spain.

\section{Literature Cited}

Alexis, M.N. 1997. Fish meal and fish oil replacers in Mediterranean marine fish diets. CIHEAM Options Mediterraneennes 183 - 204.

AOAC (Association of official Analytical Chemists). 1990. Official Methods of Analysis, $15^{\text {th }}$ end. (AOAC), Arlington, VA, USA.

Almaida Pagán, P.F., M.D. Hernández, B. García García, J.A. Madrid, J. De Costa, and P. Mendiola. 2007. Effects of total replacement of fish oil by vegetables oils on n-3 and n-6 polyunsaturated fatty acid desaturation and elongation in sharpsnout seabream (Diplodus puntazzo) hepatocytes and enterocytes. Aquaculture 272:589 - 598. 
Bell, J.G, F. McGhee, J.R. Dick, and D.R. Tocher. 2005. Dioxin and dioxin-like polychlorinated biphenyls (PCBs) in Scottish farmed salmon (Salmo salar): effects of replacement of dietary marine fish oil with vegetable oils. Aquaculture 243:305 - 314.

Benedito-Palos, L., J.C. Navarro, A. Sitjà-Bobadilla, G.J. Bell, S. Kaushik, and J. Perez-Sánchez. 2008. High levels of vegetable oils in plant protein rich diets fed to gilthead sea bream (Sparus aurata L.) growth performance, muscle fatty acid profiles and histological alterations of target tissues. British Journal of Nutrition 100:992 - 1003

Benedito-Palos, L., J.C. Navarro, A. Bermejo-Nogales, A. Saera-Vila, S. Kaushik, and J. Pérez-Sánchez. 2009. The time course of fish oil wash-out follows a simple dilution model in gilthead sea bream (Sparus aurata L.) fed graded levels of vegetable oils. Aquaculture 288:98 -105.

Bruslé, J., and G. González i Anadon. 1996. The structure and function of fish liver. Pages Science 77-93 in J. S. Datta Munshi, and H. M. Dutta, editors. Fish Morphology. CRC Press. Balkema Publishers, Brookfield, VT, USA.

Caballero, M.J., A. Obach, G. Rosenlund, D. Montero, M. Gisvold, and M.S. Izquierdo. 2002. Impact of different dietary lipid sources on growth lipid digestibility tissue fatty acid composition and histology of rainbow trout Oncorhynchus mykiss. Aquaculture 214:253-271.

Costa, C., and S. Cataudella. 2007. Relationship between shape and trophic ecology of selected species of Sparids of the Caprolace costal lagoon (Central Tyrrhenian sea). Environmental Biological Fishes $78: 115-123$.

Díaz-Lopez, M., M.J. Pérez, N.G. Acosta, D.R. Tocher, S. Jerez, A. Lorenzo, and C. Rodríguez. 2009. Effect of dietary substitution of fish oil by Echium oil on growth, plasma parameters and body lipid composition in gilthead seabream (Sparus aurata L.) Aquaculture Nutrition 15: $500-512$.

Figueiredo-Silva, A., E. Rocha, J. Dias, P. Silva, P. Rema, E. Gomes, and L.M.P. Valente. 2005. Partial replacement of fish oil by soybean oil on lipid distribution and liver histology in European sea bass (Dicentrarchus labrax) and rainbow trout (Oncorhynchus mykiss) juveniles. Aquaculture Nutrition 11:147 - 155 .

Fountoulaki, E., A. Vasilaki, R. Hurtado, K. Grigorakis, I. Karacostas, L. Nengas, G. Rigos, Y. Kotzaminis, B. Venou, and M.N. Alexi. 2009. Fish oil substitution by vegetable oils in commercial diets for gilthead sea bream (Sparus aurata L.); effects on growth performance, flesh quality and fillet fatty acid profile. Recovery of fatty acids profiles by a fish oil finishing diet under fluctuation water temperatures. Aquaculture 289:317 - 326.

Garcia-García, B., M.D. Hernández, S. Cárdenas, J.L. Muñoz, C. Rodriguez, J.F. Carrasco, E. Pastor, A. Gráu, R. Ginés, C.M. Hernández-Cruz, A. Estévez, O. Bellot, L. Rodríguez, J. Otero-Llovo, S. Martínez, and A. Tomás. 2007. Análisis sensorial de cinco especies de espáridos (Besugo, Dentón, Hurta, Pargo y Sargo picudo) en ocho localidades costeras de España. Ministerio de Medio Ambiente y Medio Rural y Marino and JACUMAR. Madrid - España.

Glencross, D. 2009. Exploring the nutritional demand for essential fatty acids by aquaculture species. Reviews in Aquaculture 1:71 - 124.

Izquierdo, M.S., A. Obach, L. Arantzamendi, D. Montero, and G. Rosenlund. 2003. Dietary lipid sources for sea bream and sea bass growth performance, tissue composition and flesh quality. Aquaculture Nutrition 9:397 - 407.

Lundebye, A-K., M.H.G. Berntssen, Ø. Lie, G. Ritchie, P. Isosaari, H. Kiviranta, and T. Vartiainen. 2004. Dietary uptake of dioxins (PCDD/PCDFs) and dioxin-like PCBs in Atlantic salmon (Salmo salar). Aquaculture Nutrition 10:199 - 207.

Martínez-Llorens, S., A. Tomás Vidal, A.V. Moñino, M. Pla Torres, and M. Jover Cerda. 2007. Effects of dietary soybean oil concentration on growth, nutrient utilization and muscle fatty acid composition of gilthead se bream (Sparus aurata L.).Aquaculture Research 38:76 -81.

Martino, R.C., J.E.P. Cyprino, L. Portz, and L.C. Trugo. 2002. Performance and fatty acid composition of surubim (Pseudoplatystoma coruscans) fed diets with animal and plant lipids. Aquaculture 209:233 - 246.

McFadzen, I.R.B., S.H. Coombs, and N.C. Halliday. 1997. Histological indices of the nutritional condition of sardine, Sardina pilchardus (Walbaum) larvae off the north coast of Spain. Journal of Experimental Marine Biology and Ecology 212:239 - 258.

Mena Sellés, C., and B. García García. 2002. Importancia de la proteína vegetal en la dieta natural de poblaciones salvajes de Sargo picudo Diplodus puntazzo (Cetti, 1777): sus implicaciones en el cultivo intensivo. AquaTIC $\mathrm{N}^{\circ}$ 17. (www.revistaaquatic.com)

Nogales-Mérida, S., A. Tomás-Vidal, S. Martínez-Llorens, and M. Jover Cerda. 2010. Sunflower meal as a partial substitute in juvenile sharpsnout sea bream (Diplodus puntazzo) diets: Amino acid retention, gut and liver histology. Aquaculture 298:275 - 281 . 
Nogales-Mérida, S., A. Tomás-Vidal, M. Jover Cerda, and S. Martínez-Llorens. 2011. Growth performance, histological alterations and fatty acid profile in muscle and liver of sharpsnout sea bream (Diplodus puntazzo) with partial replacement of fish oil by pork fat. Aquaculture International. DOI 10.1007/s10499-010-9410-z.

Olsen, R.E., T.B. Dragnes, R. Myklebust, and E. Ringø. 2003. Effect of soybean oil and soybean lecithin on intestinal lipid composition and lipid droplet accumulation of rainbow trout, Oncorhynchus mykiss Walbaum. Fish Physiology and Biochemistry 29:181 - 192.

O'Fallon, J.V., J.R. Busboom, M.L. Nelson, and C.T. Gaskins. 2007. A direct method for fatty acid methyl ester synthesis. Application to wet meat tissues, oils and feedstuffs. Journal of Animal Science 85:1511-1521.

Piedecausa, M.A., M.J. Mazón, B. García García, and M.D. Hernández. 2007. Effects of total replacement of fish oil by vegetable oils in the diets of sharpsnout sea bream (Diplodus puntazzo). Aquaculture 263:211-219.

Peng, S., L. Chen, J.G. Qin, J. Hou, N. Yu, Z. Long, J. Ye, and X. Sun. 2008. Effect of replacement of dietary fish oil by soybean oil on growth performance and liver biochemical composition in juvenile black seabream Acanthopagrus schlegeli. Aquaculture 276:154 - 161

Roberts, R.J. 1981. Patología de los peces. Ed. Mundi Prensa. Madrid, Spain.

Rueda, F.M., M.D. Hernández, M.A. Egea, F. Aguado, B. García, and F.J. Martínez. 2001. Differences in tissue fatty acid compostion between reared and wild sharpsnout sea bream, Diplodus puntazzo (Cetti, 1977). British Journal of Nutrition 86:617 - 622.

Ruyter, B., C. Moya-Falcón, G. Rosesnlund, and A. Vegusdal. 2006. Fat content and morphology of liver and intestine of Atlantic salmon (Salmo salar): Effects of temperature and dietary soybean oil. Aquaculture 252:441-452.

Sala, E., and E. Ballesteros. 1997. Partitioning of space and food resources by three fish of the genus Diplodus (Sparidae) in a Mediterranean rocky infralittoral ecosystem. Marine Ecology Progress Series 152:273- 283 .

Shearer, K.D. 2001. The effect of Diet Composition and Feeding Regime on the Proximate Composition of Farmed Fishes. Pages $31-41$ in SC Kestin and PD Warris, editors. Farmed Fish Quality. Fishing New Books publising, Bristol, United Kingdom.

Snedecor, G., and W. Cochran. 1971. Statistical Methods. The Iowas State University Press, Ames, Iowa, USA.

Tacon, A.G.J. 1992. Nutritional fish pathology Morphological signs of nutrient deficiency and toxicity in farmed fish. FAO Corporate Document Repository. Rome - Italy. http://www.fao.org/DOCREP/003/T0700s/T0700S03.htm

Turchini, G.M., B.E. Torstensen, and W-K. Ng. 2009. Fish oil replacement in finfish nutrition. Reviews in Aquaculture 1:10 - 57.

Wassef, E.A., O.M. Wahby, and E.M. Sakr. 2007. Effect of dietary vegetable oils on health and liver histology of gilthead seabream (Sparus aurata) growers. Aquaculture Research 38, 852 - 861. 


\section{CAPÍTULO 8}

Growth performance, histological alterations and fatty acid profile in muscle and liver of sharp snout sea bream (Diplodus puntazzo) with partial replacement of fish oil by pork lard

Publicada en: Aquaculture International DOI 10.1007/S10499-010-9410-z 

Aquacult Int

\title{
Growth performance, histological alterations and fatty acid profile in muscle and liver of sharp snout sea bream (Diplodus puntazzo) with partial replacement of fish oil by pork fat
}

\author{
Silvia Nogales-Mérida · Ana Tomás-Vidal · Miguel Jover Cerdá · \\ Silvia Martínez-Llorens
}

Received: 22 April 2010/Accepted: 20 December 2010

(C) Springer Science+Business Media B.V. 2011

\begin{abstract}
Four isonitrogenous (42\% crude protein) and isolipidic (20\%) diets were formulated using four different percentages of pork fat to substitute fish oil at $0,25,50$ and $75 \%$ to evaluate the performance, body composition, fatty acids and liver histology of sharpsnout sea bream juveniles. One hundred and twenty fish (average weight $33.4 \pm 2.9 \mathrm{~g}$ ) were randomly distributed into pens ( 901 capacity). Triplicate groups were fed each test diet twice a day to apparent satiation for 84 days. No difference was observed for feeding and growth performance. The only significant difference with respect to carcass was in moisture content $(P<0.05)$. With respect to liver fatty acids, there were significant differences in EPA and DHA, being fish fed $75 \%$ of pork fat that obtained the lowest value. With respect to muscle fatty acids, there were significant differences in saturated fatty acids and fish fed $0 \%$ of pork fat obtained the lowest value, but in poly unsaturated fatty acids the $75 \%$ of pork fat reported the lowest value. Although in both fish muscle and liver fatty acids, fish fed $75 \%$ pork fat diet presented significant difference in $\mathrm{n}-3$ highly unsaturated fatty acids and $n 3 / n 6$, but in LA fish fed the $0 \%$ of pork fat diet presented the lowest value in liver and in fish muscle not only the $0 \%$ but also the $25 \%$ of pork fat diet obtained the lowest value.
\end{abstract}

Keywords Pork fat · Fatty acids - Fish oil - Histology · Liver - Muscle

\section{Introduction}

Many authors have addressed the issue of fish oil (FO) replacement in aquafeeds (Xue et al. 2006) due to the limited supply and high cost of fish oils and fishmeal, along with the possible accumulation of dioxins and dioxin-like polychlorinated biphenyls in fish oils, which have forced the industry to investigate alternative lipid sources for using in fish diets (FSAI 2005; Lundebye et al. 2004; Turchini et al. 2009). Marine fish oils and most

\footnotetext{
S. Nogales-Mérida $(\square)$ - A. Tomás-Vidal - M. J. Cerdá · S. Martínez-Llorens Aquatic Resources Research Group. Animal Science Department, Polytechnic University of Valencia, Camino de Vera, 14, 46071 Valencia, Spain e-mail: silvianogales@hotmail.com
} 
vegetable oils, which contain a high proportion of polyunsaturated fatty acid (PUFA), are very susceptible to peroxidation (Sargent et al. 2002). Fish oil replacement with alternative lipid sources seems to be possible if the essential fatty acid (EFA) requirements are satisfied (Sargent and Tacon 1999). Terrestrial animal fats and/or vegetable oils, with lower cost and greater supplies, may therefore be good substitutes for FO. According to

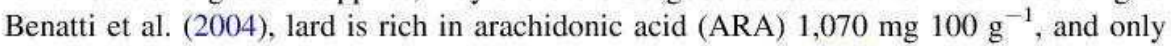
shark oil has a higher quantity. Moreover, as Izquierdo et al. (2005) mention, marine fish have low ability to convert some abundant vegetable oils such as linoleic (LA) and linolenic acids (LNA) into ARA and eicosapentaenoic (EPA), and docosahexaenoic acids (DHA).

In the last century, lard began to be considered less healthy than vegetable oils (such as olive and sunflower oil), due to its high saturated fatty acid and cholesterol content. But recently some researchers have indicated that the chemical characteristics of animal fats can vary widely depending on dietary history, species and age (Turchini et al. 2009) as well as body portion and sex (Kotch et al. 1968). In the case of pork fat, the feeding background influence the fatty acid composition being pork fed with acorn fruits that present a higher C18:2 and C18:1 (Diaz et al. 1996) and C20:5n-3 than pigs fed with commercial diets (Ventanas et al. 2007).

Nevertheless, terrestrial animal fats have been tested in some aquaculture experiments with acceptable results at a certain level to replace fish oil. Fish oil was replaced by pork fat (PF), beef tallow and other vegetable oils in Lateolabrax japonicus with good results (Xue et al. 2006). Turchini et al. (2003) totally replaced fish oil with alternative oils including pork fat in Salmo trutta, reporting the lowest growth for pork fat. Caballero et al. (2002) also replaced fish oil by other oils including a mix with $60 \%$ of pork fat and $30 \%$ of olive oil on Oncorhynchus mykiss, without significant differences in growth and feed efficiency among experimental diets, although the authors reported alteration in fish liver fed with the mix of pork fat and olive oil.

Another aspect that should be considered is the wide availability and economical price of rendered animal fats, which make them attractive alternatives to fish oil in fish-feed formulations. Besides, animal fats contain n-3 HUFA, which is not the case for many vegetable oils (Turchini et al. 2009).

This research could help to find an alternative to a partial replacement of fish oil by mammalian oil (pork fat), a cheap and available lipid source to fish diet. Besides, this omnivorous fish could reach a higher substitution levels than carnivorous fish like Sparus aurata, providing a low cost production without affecting fish health.

No trials have been conducted in Diplodus species replacing fish oil with animal fat, or histological investigation of the same, and how animal fat could affect sharpsnout sea bream liver morphology, growth performance, feed efficiency and fatty acids, so the aim of this trial was to evaluate the effect of fish oil replacement on fish growth, muscle and liver fatty acid profile and the histological alteration that this alternative might cause in liver morphology.

\section{Methods}

Experimental design

Sharpsnout sea bream were fed four iso-nitrogenous and iso-lipid extruded diets (see Table 1), produced in our laboratory with a semi-industrial twin-screw extruder

\section{$\underline{\text { Springer }}$}


Table 1 Ingredients $(\mathrm{g} / \mathrm{kg})$ and proximate composition of the experimental diets containing different percentage of pork fat

\begin{tabular}{|c|c|c|c|c|}
\hline Ingredients $\left(\mathrm{g} \mathrm{kg}^{-1}\right)$ & $\begin{array}{l}\text { Diet } 1 \\
0 \%\end{array}$ & $\begin{array}{l}\text { Diet } 2 \\
25 \%\end{array}$ & $\begin{array}{l}\text { Diet } 3 \\
50 \%\end{array}$ & $\begin{array}{l}\text { Diet } 4 \\
75 \%\end{array}$ \\
\hline Fishmeal $(5-02-000)^{\mathrm{a}}$ & 454 & 454 & 454 & 454 \\
\hline Sunflower meal $(5-04-739)^{\mathrm{b}}$ & 235 & 235 & 235 & 235 \\
\hline Wheat $(4-05-268)^{c}$ & 94 & 94 & 94 & 94 \\
\hline Dextrin (4-08-023) & 50 & 50 & 50 & 50 \\
\hline Fish oil (7-08-048) & 157 & 107 & 57 & 7 \\
\hline Pork fat & & 50 & 100 & 150 \\
\hline Vitamin \& mineral mix ${ }^{\mathrm{d}}$ & 10 & 10 & 10 & 10 \\
\hline \multicolumn{5}{|l|}{ Proximate analyses $\mathrm{g} \mathrm{kg}^{-1}$} \\
\hline Dry matter (DM) & 933.1 & 926.7 & 927.9 & 926.2 \\
\hline Crude protein $(\mathrm{CP})$ & 415.1 & 425.1 & 422.5 & 423.5 \\
\hline Crude lipid (CL) & 206.2 & 193.1 & 198.1 & 200.8 \\
\hline Ash & 109.5 & 107.9 & 109.0 & 108.9 \\
\hline Crude fibre (CF) & 48.5 & 49.6 & 49.3 & 49.5 \\
\hline \multicolumn{5}{|l|}{ Calculated values } \\
\hline Carbohydrate $\left(\mathrm{g} \mathrm{kg}^{-1}\right)^{\mathrm{e}}$ & 220.7 & 224.3 & 221.1 & 217.3 \\
\hline $\mathrm{GE}\left(\mathrm{Mj} \mathrm{kg}^{-1}\right)^{f}$ & 22.01 & 21.81 & 21.89 & 21.96 \\
\hline $\mathrm{CP} / \mathrm{GE}\left(\mathrm{g} \mathrm{MJ}^{-1}\right)^{\mathrm{f}}$ & 20.49 & 19.49 & 19.30 & 19.28 \\
\hline
\end{tabular}

All analyses were performed in the Animal Science Department feed nutrition laboratory

${ }^{a}$ Fishmeal: $\left(\mathrm{g} \mathrm{kg}^{-1}\right)$ DM: $93.6 \%$; CP: 729; CL: 87; Ash: 170; GE: $20.89 \mathrm{Mj} \mathrm{kg}^{-1}$

b Sunflower meal $\left(\mathrm{g} \mathrm{kg}^{-1}\right)$ : DM: 914; CP: 383; CL: 22; CF: 210; Ash: 80 NFE: 305; GE: $15.39 \mathrm{Mj} \mathrm{kg}^{-1}$

${ }^{\circ}$ Wheat $\left(\mathrm{g} \mathrm{kg}^{-1}\right)$ : DM: 885; CP: 91; CL: 21, CF: 32; Ash: 15; NFE: 840 , GE: $17.79 \mathrm{Mj} \mathrm{kg}^{-1}$

d Vitamin and mineral mix (values are $\mathrm{g} / \mathrm{kg}$ except those in parentheses): Premix: 20; Choline. 10; DL- $\alpha-$ tocopherol. 5; ascorbic acid. 5; Premix composition: retinol acetate (1,000,000 IU/kg); calcipherol. ( 500 $\left.\mathrm{IUkg}^{-1}\right)$; DL- $\alpha$-tocopherol. 10; menadione sodium bisulphite. 0.8 ; thiamine hydrochloride. 2.3 ; riboflavin. 2.3; pyridoxine hydrochloride. 15 ; cyanocobalamin. 25 ; nicotinamide. 15 ; pantothenic acid. 6 ; folic acid. 0.65 ; biotin. 0.07 ; ascorbic acid. 75 ; inositol. 15 ; betaine. 100 ; polypeptides. 12 ; Zn. 5 ; Se. 0.02 ; I. 0.5 ; Fe. 0.2; CuO. 15; Mg. 5.75; Co. 0.02; Met. 0.2; Cys. 0.8; Lys. 1.3; Arg. 0.6; Phe. 0.4; Try. 0.7; Excipient. to $1,000 \mathrm{~g}$ (Source: Dibaq-Diproteg)

- Carbohydrate $=1,000-(\mathrm{CP}-\mathrm{CL}-\mathrm{CF}-\mathrm{Ash})$

${ }^{f}$ Gross energy: Calculated using: $23.9 \mathrm{~kJ} \mathrm{~g}^{-1}$ proteins, $39.8 \mathrm{~kJ} \mathrm{~g}^{-1}$ lipids and $17.6 \mathrm{~kJ} \mathrm{~g}^{-1}$ carbohydrates

(CLEXTRAL BC-45, Firmity, St. Etienne, France). Processing conditions were as follows: $100 \mathrm{rpm}$ speed screw, temperature $110^{\circ} \mathrm{C}$ and $30-40 \mathrm{~atm}$ pressure and 1- and 2-mmdiameter pellets, according to fish size.

The design was done with one control group fed with $100 \%$ of fish oil, and three increasing levels of pork fat $(25,50$ and $75 \%)$. The groups were tested in triplicate. The increasing levels of pork fat used to replace fish oil on the basis of dietary energy level presented an average value of $20.34 \mathrm{MJ} \mathrm{kg}^{-1}$. Dietary composition is given in Table 1. The composition of all diets was similar with $389-394 \mathrm{~g} \mathrm{~kg}^{-1}$ protein, $178-191 \mathrm{~g} \mathrm{~kg}^{-1}$ lipid, and vitamins and minerals according to NRC (1993). Experimental diets and fatty acid profile of ingredients are shown in Table 2 . 
Aquacult Int

Table 2 Fatty acid composition (\%) for fish oil, pork fat and experimental diets used to feed sharpsnout sea bream juveniles

\begin{tabular}{|c|c|c|c|c|c|c|}
\hline & \multirow[t]{2}{*}{ Fish oil \% } & \multirow[t]{2}{*}{ Pork fat $\%$} & \multicolumn{4}{|c|}{$\%$ of dietary crude lipid supplied by Pork fat } \\
\hline & & & $0 \%$ & $25 \%$ & $50 \%$ & $75 \%$ \\
\hline C14:0 & 4.64 & 1.35 & 4.98 & 4.34 & 3.13 & 2.42 \\
\hline C $15: 0$ & 0.51 & nd & 0.58 & 0.52 & 0.28 & 0.00 \\
\hline C16:0 & 15.68 & 23.29 & 18.20 & 24.91 & 23.20 & 25.62 \\
\hline C18:0 & 3.76 & 10.37 & 4.58 & 9.15 & 11.35 & 14.60 \\
\hline $\mathrm{C} 20: 0$ & 0.24 & nd & 0.26 & 0.20 & nd. & nd. \\
\hline $\mathrm{C} 22: 0$ & 0.17 & nd & 0.24 & 0.18 & 0.15 & 0.07 \\
\hline $\mathrm{C} 24: 0$ & 0.07 & nd & 0.13 & 0.13 & 0.08 & 0.06 \\
\hline SFA & 25.07 & 35.01 & 28.96 & 39.42 & 38.20 & 42.77 \\
\hline C16:1 & 5.79 & 2.19 & 5.91 & 4.43 & 3.95 & 3.19 \\
\hline $18: 1(\mathrm{n} 7)$ & 4.32 & nd & 4.07 & 3.84 & 4.87 & 5.54 \\
\hline C18:1(n9)c & 19.29 & 51.66 & 15.78 & 18.01 & 24.35 & 27.18 \\
\hline C20:1 & 4.85 & nd & 3.89 & 2.55 & 1.81 & 0.93 \\
\hline $\mathrm{C} 22: 1(\mathrm{n} 9)$ & 5.08 & nd & 3.75 & 2.31 & 1.33 & 0.30 \\
\hline $\mathrm{C} 24: 1$ & 0.82 & nd & 0.64 & 0.61 & 0.36 & 0.14 \\
\hline MUFA & 40.16 & 53.84 & 34.04 & 31.75 & 36.68 & 37.27 \\
\hline $\mathrm{C} 18: 2(\mathrm{n} 6) \mathrm{t}$ & 0.00 & nd & - & - & - & - \\
\hline $\mathrm{C} 18: 2(\mathrm{n} 6) \mathrm{C}$ & 5.74 & 9.25 & 6.38 & 7.70 & 9.11 & 9.85 \\
\hline C18:3(n3) & 2.15 & 1.21 & 1.49 & 1.32 & 1.22 & 0.91 \\
\hline C18:3(n6) & 0.19 & nd & 0.16 & 0.11 & 0.09 & 0.00 \\
\hline $\mathrm{C} 20: 2(\mathrm{n} 6)$ & 2.07 & nd & 1.98 & 1.27 & 1.13 & 0.75 \\
\hline $\mathrm{C} 20: 3(\mathrm{n} 3)$ & 1.20 & nd & 0.22 & 0.18 & 0.16 & 0.12 \\
\hline $\mathrm{C} 20: 3(\mathrm{n} 6)$ & 0.20 & & 0.17 & 0.11 & 0.11 & 0.08 \\
\hline C20:4(n6) & 0.94 & 0.08 & 1.22 & 0.90 & 0.71 & 0.51 \\
\hline $\mathrm{C} 20: 5(\mathrm{n} 3)$ & 7.87 & nd & 8.89 & 6.31 & 4.83 & 3.19 \\
\hline $\mathrm{C} 22: 2$ & 0.98 & nd & 0.74 & 0.51 & 0.33 & 0.15 \\
\hline $22: 5(\mathrm{n} 3)$ & 2.25 & nd & 2.05 & 1.40 & 1.04 & 0.67 \\
\hline $\mathrm{C} 22: 6(\mathrm{n} 3)$ & 10.44 & nd & 12.77 & 8.14 & 5.64 & 3.03 \\
\hline PUFA & 34.02 & 10.54 & 36.05 & 27.94 & 24.36 & 18.35 \\
\hline n-3 HUFA & 20.60 & 0 & 23.70 & 15.84 & 11.50 & 6.89 \\
\hline $\mathrm{n} 3$ & 23.90 & 1.21 & 25.41 & 17.34 & 12.88 & 7.00 \\
\hline n6 & 9.14 & 9.34 & 9.90 & 10.09 & 11.15 & 11.20 \\
\hline $\mathrm{n} 3 / \mathrm{n} 6$ & 2.61 & 0.13 & 2.57 & 1.72 & 1.15 & 0.63 \\
\hline EPA/DHA & 0.75 & nd & 0.70 & 0.78 & 0.86 & 1.05 \\
\hline $\mathrm{n} 6 / \mathrm{n} 3$ & 0.38 & 7.73 & 0.39 & 0.58 & 0.87 & 1.60 \\
\hline
\end{tabular}

SFA saturated fatty acids, MUFA mono un-saturated fatty acids, PUFA poly unsaturated fatty acids, $n-3$ HUFA: $\mathrm{n}-3$ highly unsaturated fatty acids, $c$ cis, $t$ trans

Animals and husbandry

Ten fish per pen was introduced. A total of 120 juveniles (average weight $33.4 \pm 2.9 \mathrm{~g}$ ) were distributed in 12 pens (three pens per fibre cylindrical tanks of 7501 of capacity).

\section{Springer}


Each pen has a 981 capacity. The fish were from University of Valencia, Spain. The trial took place at the Science Department Aquaculture Laboratory of the Polytechnic University of Valencia. The trial lasted 84 days (March 10th to June 2nd).

Water parameters were recorded three times per week, and average temperature during the trial was $22.8 \pm 1.3^{\circ} \mathrm{C}$, dissolved oxygen $6.5 \pm 0.3 \mathrm{mg} \mathrm{l}^{-1}$, salinity $27.7 \pm 2.2$, pH values $6.5 \pm 0.1, \mathrm{NO}_{2}{ }^{-} 0.19 \pm 0.1, \mathrm{NH}_{4}{ }^{+} 0.0, \mathrm{NO}_{3}{ }^{-} 31.1 \pm 12.8$. Photoperiod was natural and all tanks had similar light conditions.

During the experimental period, sharpsnout sea bream juveniles were fed to apparent satiation, twice a day from Monday through Friday (0900 and 1500) and once on Saturday at mid-day.

Sampling procedure

Fish were weighed at the beginning of the experiment and every 28 days until the end of the trial. All fish were anaesthetised with clove oil at $30 \mathrm{mg} \mathrm{1}$, containing $87 \%$ of euglenol (Guinama ${ }^{(}$, Valencia Spain) and individually weighed. During the trial, apparent feed intake was monitored for each experimental group in order to measure their daily intake rate (FI). The effects on growth were determined by evaluating a number of growth and nutrient utilisation indexes, including weight gain. Specific growth rate $\left(\%\right.$ day $\left.^{-1}\right)$, SGR $=100 \times \ln ($ final weight $(\mathrm{g}) /$ initial weight $(\mathrm{g})) /$ days. Thermal coefficient of growth, $\mathrm{TCG}=1,000 *\left[\mathrm{Fw}^{1 / 3}-\mathrm{Iw}^{1 / 3}\right] /\left(\mathrm{T}^{\circ} \mathrm{C}\right.$-minimum $\mathrm{T}^{\circ} \mathrm{C}$ to feed $)$, apparent feed conversion ratio, $\mathrm{FCR}=$ feed offered $(\mathrm{g}) /$ biomass gain $(\mathrm{g})$. Apparent feed intake $\left(\mathrm{g} 100 \mathrm{~g} \mathrm{fish}^{-1}\right.$ day $\left.^{-1}\right)$, $\mathrm{AFI}=100 \times$ feed offered $(\mathrm{g}) /$ average biomass $(\mathrm{g}) \times$ days. Protein efficiency ratio, PER $=$ Biomass gain $(\mathrm{g}) /$ protein offered $(\mathrm{g})$. Crude protein efficiency, CPE $(\%)$ : Fish protein gain $(\mathrm{g}) \times 100 /$ protein intake $(\mathrm{g})$. Gross energy efficiency, GEE $(\%)$ : Fish energy gain $(\mathrm{kJ}) \times 100 /$ energy intake $(\mathrm{kJ})$, as well as the survival percentage.

At the beginning of the experiment, five fish were collected for carcass analyses and at the end of the experiment; five fish per pen were collected for biometric analyses. Of the collected fish, two from each pen were sampled for histological analyses and fatty acids from liver and muscle. The other three fish from each pen were used for carcass analyses.

\section{Analytical methods}

Chemical analyses of the dietary ingredients were carried out prior to diet formulation. Diets and their ingredients as well as the whole fish were analysed according to A.O.A.C (1990) procedures: dry matter $\left(105^{\circ} \mathrm{C}\right.$ to constant weight), ash (incinerated at $550^{\circ} \mathrm{C}$ to constant weight $)$ and crude protein $(\mathrm{N} \times 6.25)$ by the Kjeldahl method after an acid digestion (Kjeltec 2300 Auto Analyser, Tecator Höganas, Sweden), crude lipid extracted with methyl-ether (Soxtec 1043 extraction unit, Tecator) and crude fibre by acid and basic digestion (Fibertec System M., 1020 Hot Extractor, Tecator). All analyses were performed in triplicate.

Fatty acid methyl esters of total lipids were prepared directly as previously described by O'Fallon, et al. (2007). FAME was done with raw material, experimental diets and six subsamples of liver and muscles from each treatment. The analyses were performed in a Focus gas chromatograph (Thermo, Milan, Italy) equipped with a split/splitless injector and a flame ionisation detector. Separation of methyl esters was performed in a fused silica capillary column $\mathrm{SP}^{\mathrm{TM}} 2,560$ (Supelco, PA, USA; $100 \mathrm{~m} \times 0.25 \mathrm{~mm} \times 0.2 \mu \mathrm{m}$ film thickness). The carrier gas was Helium at a linear velocity of $20 \mathrm{~cm} / \mathrm{s}$. The samples were injected with a split ratio of $1 / 100$. The initial oven temperature was set at $140^{\circ} \mathrm{C}$ held for 
$5 \mathrm{~min}$ and increased to 240 at $4^{\circ} \mathrm{C} / \mathrm{min}$ and finally maintained at that temperature for $30 \mathrm{~min}$. Both detector and injector temperatures were set at $260^{\circ} \mathrm{C}$. The individual fatty acids were identified by comparing their retention times with standards of fatty acid methyl esters supplied by Supelco (PA, USA).

Histological analyses

Tissue samples were fixed in phosphate-buffered formalin $(4 \% \mathrm{pH} \mathrm{7.4)}$ and then transferred to $70 \%$ of ethanol for storage until processing. All formalin fixed tissues were routinely dehydrated in ethanol, equilibrated in Ultraclear ${ }^{\mathrm{TM}}$ and embedded in paraffin according to standard histological techniques (Sheehan and Hrapchek 1983). Liver sections (approximately $5 \mu \mathrm{m}$ thick) were cut and stained with haematoxylin and eosin ( $\mathrm{H}$ and $\mathrm{E}$ ). Blinded histological examination was performed by light microscopy (Nikon Phase Contrast 0.90 Dry JAPAN). The McFadzen et al. 's(1997) criteria were used in liver morphology evaluation, in addition to quantification of hepatocytes, to observe possible alterations revealed through differences in the hepatocyte condition or hepatic cell morphology. The quantification was done per area $\left(125,000 \mu \mathrm{m}^{2}\right)$.

Statistical analyses

Growth data and nutritive parameters were treated using multifactor analyses of variance (ANOVA), introducing the initial live weight as covariate (Snedecor and Cochran 1971). Newman-Keuls test was used to assess specific differences among diets at 0.05 significant levels (Stat graphics, Statistical Graphics System, Version Plus 5.1, Herndon, Virginia, USA). Histological analyses of hepatocytes and acinar cells were performed using the McFadzen et al.'s (1997) methodology and evaluated by a cross tabulation and chi square contrast $\left(\mathrm{X}^{2}\right)$ on Statgraphics.

\section{Results}

In Table 2, the FAA of experimental diets and raw material are presented. Fish oil replacement affected the fatty acid content in experimental diets, especially in C16:0, $\mathrm{C} 18: 0, \mathrm{C} 18: 1 \mathrm{n} 9$ and $\mathrm{C} 18: 2 \mathrm{n} 6$ increasing the percentage as $\mathrm{PF}$ incremented in experimental diets, on the contrary $\mathrm{C} 20: 0, \mathrm{C} 18: 3 \mathrm{n} 3, \mathrm{C} 20: 4 \mathrm{n} 6, \mathrm{C} 20: 5 \mathrm{n} 3$ and $\mathrm{C} 22: 6 \mathrm{n} 3$ diminished as FO decreased in the diets. If we consider the EFA, only linoleic acid presented a positive value as the PF substitution increased $(6.38 ; 7.70 ; 9.11 ; 9.85 \%$, respectively). The PUFA content also diminished as PF increased in experimental diets. In addition, the high unsaturated fatty acids ( $\mathrm{n}-3$ HUFA) was absent in PF analyses, causing a gradual reduction as PF content increased in experimental diets $(23.7,15.84,11.5$, and $6.89 \%$, respectively). Fish survival at the end of the trial was similar in all treatment $(97 \%)$.

Growth and feed efficiency are reported in Table 3. At the end of the trial, no significant differences were observed in growth or nutritive parameters. Specific growth rate fluctuated from 1.37 to $1.27 \%$ day $^{-1}$. Apparent feed intake ranged from 2.69 to $2.49 \mathrm{~g} 100 \mathrm{~g}$ fish $^{-1}$.

Biometric values are also presented in Table 3. There were no significant differences in any parameters measured. HSI fluctuated from 1.35 to $1.46 \%$ among treatments and MFI ranged from 2.61 to $2.96 \%$. 
Table 3 Growth performance, diet utilisation and biometric parameters in sharpsnout sea bream fed the experimental diets

\begin{tabular}{|c|c|c|c|c|c|c|}
\hline & \multicolumn{6}{|c|}{$\%$ of dietary crude lipid supplied by Pork fat } \\
\hline & Control $0 \%$ & $25 \%$ & $50 \%$ & $75 \%$ & S.E.M. & $P$ value \\
\hline Final weight $(\mathrm{g})$ & 105.68 & 105.24 & 98.61 & 96.80 & 2.51 & 0.0863 \\
\hline Weight gain $(\%)$ & 221.8 & 214.8 & 199.5 & 185.0 & 10.35 & 0.1379 \\
\hline SGR $\left(\% \text { day }^{-1}\right)^{\mathrm{a}}$ & 1.37 & 1.37 & 1.29 & 1.27 & 0.03 & 0.0804 \\
\hline $\mathrm{FCR}^{\mathrm{b}}$ & 2.17 & 2.04 & 2.13 & 2.21 & 0.07 & 0.4507 \\
\hline PER $^{\mathrm{C}}$ & 1.19 & 1.21 & 1.17 & 1.19 & 0.04 & 0.8922 \\
\hline AFI $\left(g 100 \mathrm{~g} \mathrm{fish}^{-1}\right)^{d}$ & 2.69 & 2.50 & 2.52 & 2.49 & 0.06 & 0.1222 \\
\hline $\mathrm{TCG}^{\mathrm{e}}$ & 1.88 & 1.86 & 1.74 & 1.69 & 0.05 & 0.0563 \\
\hline \multicolumn{7}{|c|}{ Biometric parameters $(\%)$} \\
\hline $\mathrm{CF}^{f}$ & 2.18 & 2.19 & 2.13 & 2.12 & 0.08 & 0.9146 \\
\hline $\mathrm{HSI}^{\mathrm{g}}$ & 1.44 & 1.35 & 1.47 & 1.46 & 0.08 & 0.6325 \\
\hline $\mathrm{MFI}^{\mathrm{h}}$ & 2.61 & $2 . .90$ & 2.76 & 2.96 & 0.03 & 0.8321 \\
\hline $\mathrm{VSI}^{\mathrm{i}}$ & 9.75 & 9.86 & 10.00 & 10.27 & 0.32 & 0.6871 \\
\hline Dressout $^{j}$ & 76 & 77 & 75 & 75 & 0.01 & 0.2126 \\
\hline
\end{tabular}

No statistical differences were found $\mathrm{P}>0.05$ (mean \pm S.E.M.; $\mathrm{n}=12$ )

Initial weight in each phase was considered as co-variable for live weight and SGR

${ }^{a}$ Specific growth rate $\left(\%\right.$ day $\left.^{-1}\right), \mathrm{SGR}=100 \times \ln$ (final weight $(\mathrm{g}) /$ initial weight $\left.(\mathrm{g})\right) /$ days

b Apparent feed conversion ratio, FCR $=$ feed offered $(\mathrm{g}) /$ biomass gain $(\mathrm{g})$

c Protein efficiency ratio, PER $=$ Biomass gain $(\mathrm{g}) /$ protein offered $(\mathrm{g})$

d Apparent Feed Intake ( $\mathrm{g} 100 \mathrm{~g}_{\text {fish }}^{-1}$ day $^{-1}$ ), FI $=100 \times$ feed offered $(\mathrm{g}) /$ average biomass $(\mathrm{g}) \times$ days

c Thermal Coefficient of Growth, TCG $=1,000^{*}\left[\mathrm{Fw}^{1 / 3}-\mathrm{Iw}^{1 / 3}\right] /\left(\mathrm{T}^{\circ} \mathrm{C}-\right.$ minimum $\mathrm{T}^{\mathrm{C}} \mathrm{C}$ to feed)

${ }^{f}$ Condition Factor, $\mathrm{CF}=\left[\right.$ fish weight $(\mathrm{g}) /$ total length $\left.(\mathrm{cm})^{3}\right] \times 100$

${ }^{2}$ Hepatosomatic index, HSI $=[$ liver weight $(\mathrm{g}) /$ fish weight $(\mathrm{g})] \times 100$

${ }^{\text {h }}$ Mesenteric fat index, MFI $=[$ mesenteric fat weight $(\mathrm{g}) /$ fish weight $(\mathrm{g})] \times 100$

${ }^{i}$ Viscerosomatic index, VSI $=100 \times$ [visceral weight $(\mathrm{g}) /$ fish weight $\left.(\mathrm{g})\right]$

j Dress out percentage, DP $=100 \times[$ total fish weight $(\mathrm{g})$ - visceral weight $(\mathrm{g})$ - head weight $(\mathrm{g})] /$ fish weight $(\mathrm{g})$

Body composition is shown in Fig. 1. Moisture was the only parameter that presented statistical difference, with fish fed the control diet and $75 \%$ diet, obtaining the lowest value (63.55 and $64.24 \%$ ) compared with 25 and $50 \%$. In crude protein efficiency (CPE) and crude energy efficiency (CEE), there were no significant differences among treatments. There were no significant differences in GE, and all treatments presented similar values (9.53-10.31 $\mathrm{MJ} \mathrm{kg}^{-1}$ ).

Fatty acid levels in liver and muscle were affected by lipid composition of experimental diets (Fig. 2). In liver, there were significant differences in n-3 HUFA and fish fed with $75 \%$ of substitution with pork fat exhibited the lowest value $(12.75 \%)$ compared to 0,25 , $50 \%$ of pork fat inclusion $(20.19,18.38$ and $15.55 \%$, respectively). On the contrary, LA (C18-2n6), in fish fed 0 and $25 \%$ of pork fat presented the lowest values (4.82 and $6.02 \%)$.

In liver, fish fed with $75 \%$ of substitution with pork fat presented the lowest values in EPA, DHA and n3/n6 (3.01, 7.66 and $1.45 \%$, respectively) $(P<0.05)$. In fish muscle, fish fed $0 \%$ of pork fat exhibited the lowest value in saturated fatty acids $(28.56 \%)$ and in 


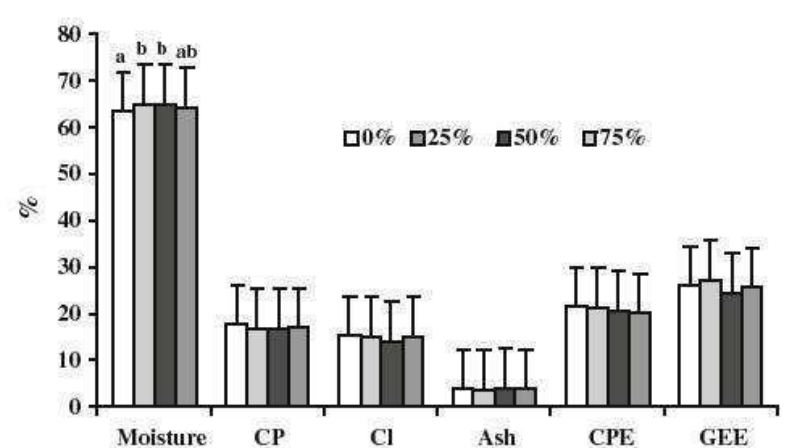

Fig. 1 Proximate composition and protein and energy efficiency of Diplodus puntazzo fed the experimental diets. Data represent the mean \pm SEM of three replicates. Values for the same parameter with different superscripts are significantly different $(P<0.05)$. Gross energy, GE $\left(\mathrm{Mj} \mathrm{kg}^{-1}\right)$ : calculated using: $23.9 \mathrm{~kJ} \mathrm{~g}^{-1}$ proteins, $39.8 \mathrm{~kJ} \mathrm{~g}^{-1}$ lipids and $17.6 \mathrm{~kJ} \mathrm{~g}^{-1}$ carbohydrates crude protein efficiency, CPE $(\%)$ : Fish protein gain $(\mathrm{g}) \times 100 /$ protein intake $(\mathrm{g})$. Gross energy efficiency, GEE $(\%)$ : Fish energy gain $(\mathrm{kJ}) \times 100$ /energy intake $(\mathrm{kJ})$

C18:2n6 (7.09\%), but in polyunsaturated fatty acids (PUFA), n-3 HUFA and the n3/n6 presented the highest values $(39.22,27.29$ and $2.84 \%$, respectively) $(P<0.05)$.

Figure 3 shows the relationship between EFA in muscle and experimental diets, and the EFA in liver and experimental diets. Significant differences were observed for ARA, EPA and DHA in muscle and liver. In muscle (Fig. 3a), fish fed 50 and $75 \%$ of pork fat exhibited the highest percentages (2.66 and 3.04\%), and in DHA, the highest value reached was $75 \%$ of pork fat $(3.38 \%)$. In liver (Fig. 3b), similar results were obtained, with fish fed the $75 \%$ of pork fat diet reporting the highest value in ARA, EPA and DHA $(2.36,0.94$ and $2.52 \%)(P<0.05)$.

Table 4 shows significant differences among treatments. Fish fed 0 and $75 \%$ of pork fat diets presented the lowest values (768 and 746 hepatocytes $/ 125,000 \mu \mathrm{m}^{2}$ ) in comparison with 25 and $50 \%(P<0.05)$. However, if we compared the liver nuclei, liver hepatocyte cytoplasm, hepatocyte vacuolation and pancreatic acinar cells among treatments, no significant differences were reported. In Fig. 4, the hepatic cells of different treatments exhibited similar morphology, but with a slight increment in intracellular lipid deposition.

\section{Discussion}

As expected, fatty acids levels were correlated with the quantity of pork fat substitution, but it seemed that this modification did not affect fish survival at the end of the trial. Similar results were reported by Turchini et al. (2003), who noted a mortality rate from 1.18 to $7.06 \%$ per tank.

Fish growth parameters were not affected by pork fat inclusion in the experimental diets; similar results were reported by Heck and Calbert (1977) who partially replaced fish oil by pork fat in yellow perch Perca flavescens. Similar results were reported by Xue et al. (2006), Caballero et al. (2002) and Turchini et al. (2003) who replaced 50, 60 and 100\%, respectively, of fish oil by soybean oil, corn oil, rapeseed oil, olive oil, palm oil, canola oil, beef tallow, poultry fat and pork fat inclusion in carnivorous fishes. Turchini et al. (2009) also indicated that animal fats when incorporated at no more than $50 \%$ of the dietary lipid 

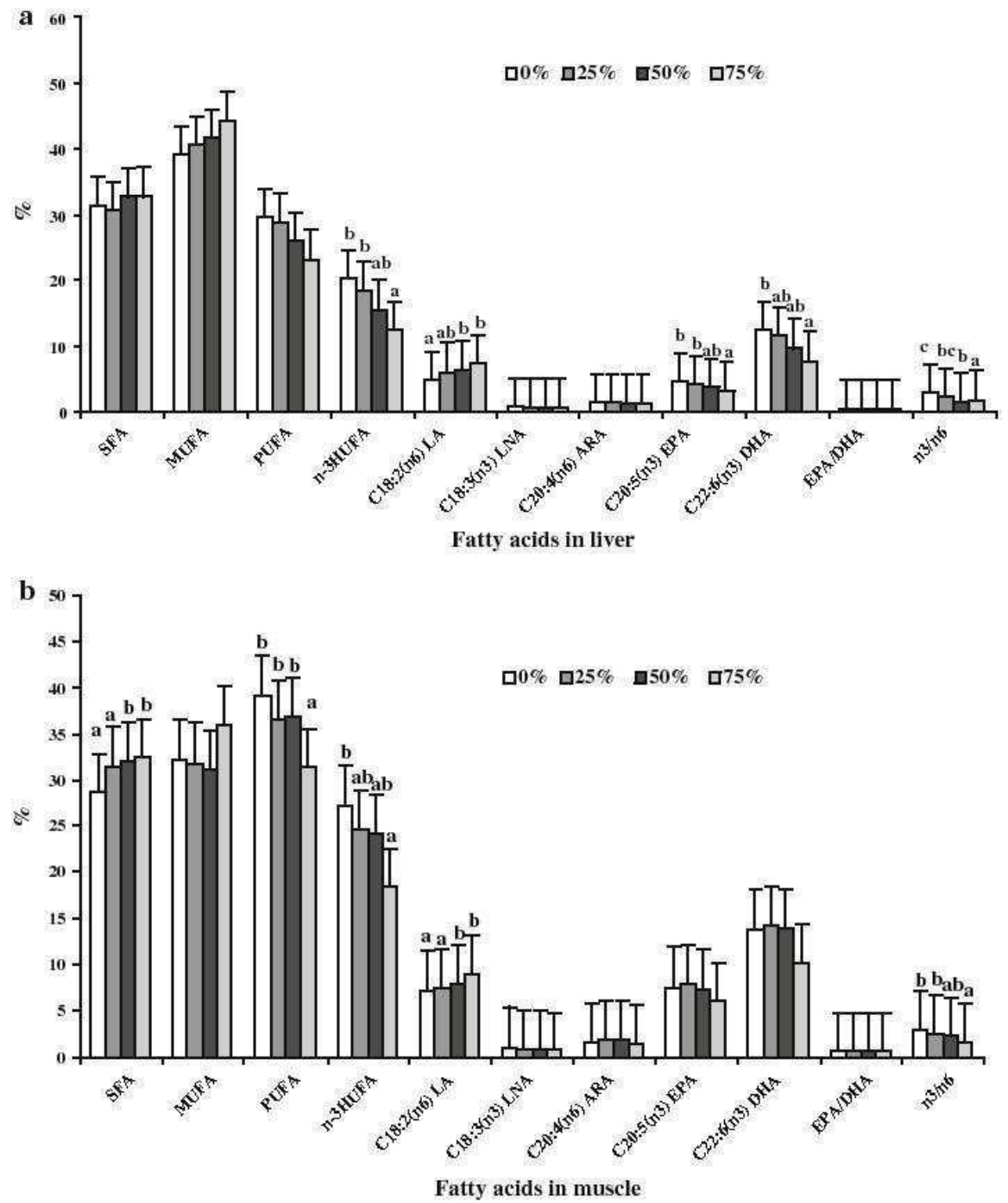

Fig. 2 Fatty acids in liver (a) and muscle (b) of sharpsnout sea bream fed with the experimental diets at the end of the trial. Values expressed in percentage of fame identified in samples. Data are the means $(n=24)$ \pm SEM. Different letters denote significant differences $P<0.05$. SFA: Saturated fatty acids; MUFA: Mono unsaturated fatty acids; PUFA: Poly unsaturated fatty acids; n-3 HUFA: Highly unsaturated fatty acids; LA: Linoleic acid; LNA: Linolenic acid; ARA: Arachidonic acid; EPA: Eicosapentaenoic acid; DHA: Docosahexaenoic acid

level had no negative effects on fish growth performance as long as the EFA requirements were met, which seemed to be the case. The study reported by Craig and Gatlin (1995)showed that red drum, Sciaenops ocellatus, fed a diet with beef tallow obtained a better growth in relation to fish fed a diet with fish oil. Although, oil alternatives such as 

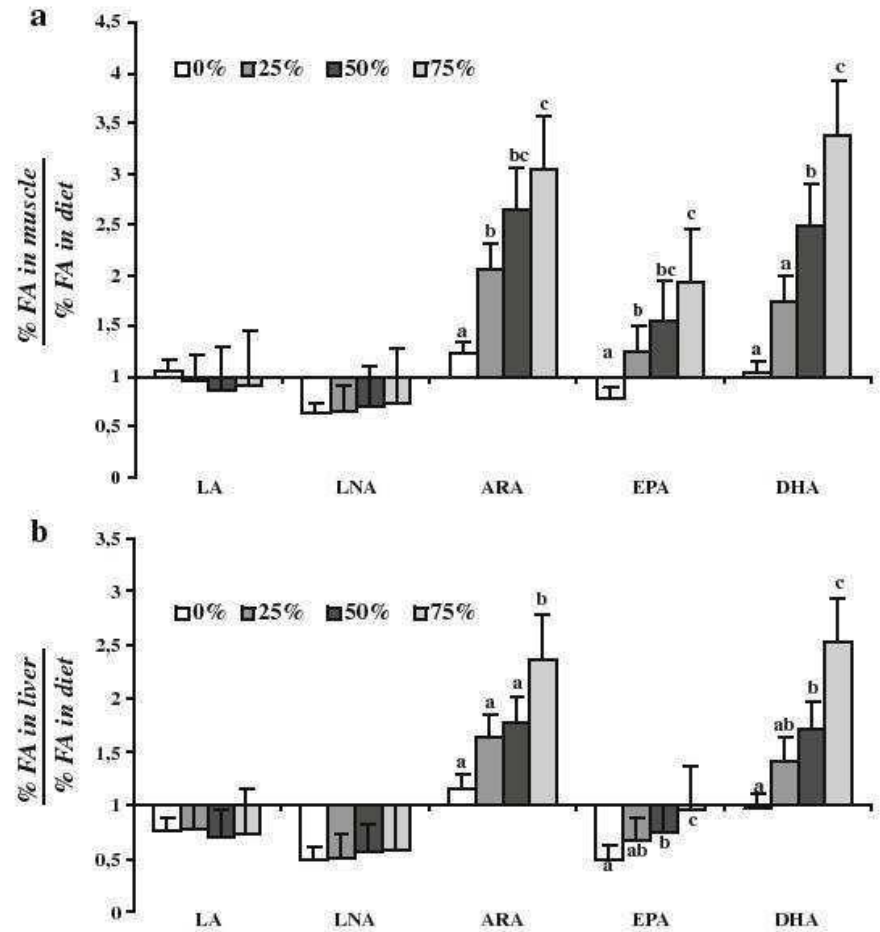

Fig. 3 The relation between percentage of essential fatty acids in muscle (a) and liver (b) of sharpsnout sea bream at the end of the experiment and the percentage of EFA in diets; Linoleic acids (LA C18: 2n6); Linolenic acids (LNA C18: 3n3), Arachidonic acid (ARA C20: 4n-6), Eicosapentaenoic acids (EPA C20: $5 \mathrm{n} 3)$ and docosahexaenoic acids (DHA C22: $6 \mathrm{n} 3$ ). Data are the means $(n=24) \pm$ SEM. Different letters denote significant differences $P<0.05$. Relation $=(\%$ EFA in muscle/liver $) / \%$ EFA in diet

Table 4 Hepatocyte quantification and histological evaluation according to McFadzen et al. (1997) methodology

\begin{tabular}{|c|c|c|c|c|c|c|c|c|c|c|c|c|}
\hline Hepatocytes ${ }^{a}$ & $\begin{array}{l}0 c \\
76\end{array}$ & & & $\begin{array}{l}25 \\
87\end{array}$ & & $\begin{array}{l}50 \% \\
899^{\mathrm{a}}\end{array}$ & $\begin{array}{l}75 \\
74\end{array}$ & & & $\begin{array}{l}\text { SEM } \\
26.4\end{array}$ & $\begin{array}{l}P \\
0 .\end{array}$ & \\
\hline \multirow[t]{2}{*}{$(\%)$} & \multicolumn{3}{|c|}{ Liver nuclei } & \multicolumn{3}{|c|}{$\begin{array}{l}\text { Liver hepatocyte } \\
\text { cytoplasm }\end{array}$} & \multicolumn{3}{|c|}{$\begin{array}{l}\text { Hepatocyte } \\
\text { vacuolation }\end{array}$} & \multicolumn{3}{|c|}{$\begin{array}{l}\text { Pancreatic } \\
\text { acinar cells }\end{array}$} \\
\hline & 1 & 2 & 3 & 1 & 2 & 3 & 1 & 2 & 3 & 1 & 2 & 3 \\
\hline 0 & 6 & - & - & 6 & & - & 5 & 1 & - & 6 & - & - \\
\hline 25 & 6 & - & - & 4 & 2 & - & 3 & 3 & - & 5 & 1 & - \\
\hline 50 & 3 & 3 & - & 3 & 2 & 1 & 3 & 2 & 1 & 4 & 2 & - \\
\hline 75 & 5 & - & 1 & 5 & - & 1 & 4 & 1 & 1 & 5 & 1 & - \\
\hline
\end{tabular}

1 (Healthy). 2. (Intermediate) 3 (Degraded)

Data represent the mean \pm statistical error medium of six replicates per treatment $(P>0.05)$

${ }^{\text {a }}$ Hepatocytes $/ 125,000 \mu \mathrm{m}^{2}$ 

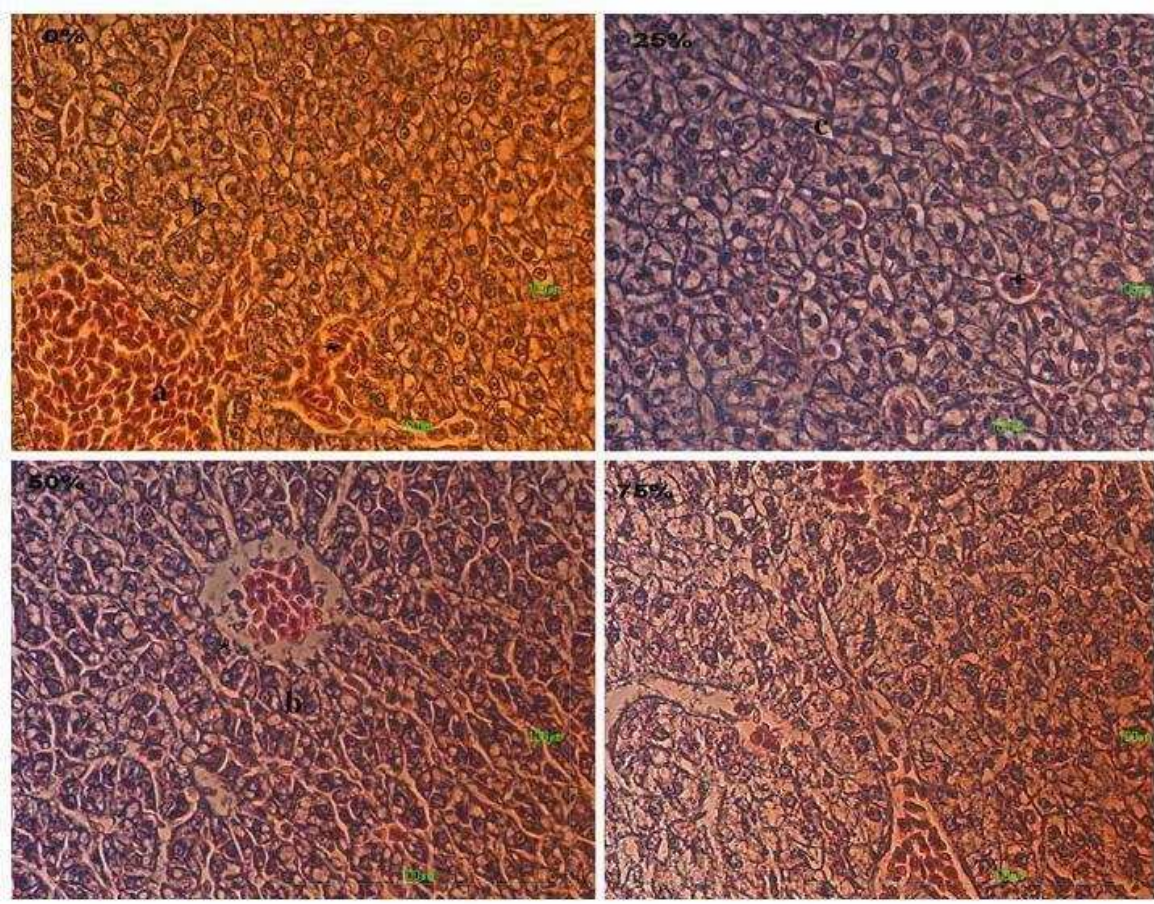

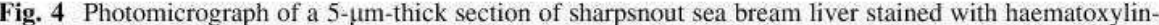
eosin (from left to right and up to down; 0, 25, 50 and 75\%). a Hepatocytes, b blood vessel, c sinusoids (photograph at $40 \times$ )

lard used to replace fish oil in shrimp (Litopenaeus vannamei) seemed not to perform well, as Zhou et al. (2007) reported.

In nutritional parameters, there were no statistical differences; it seemed that the experimental diets were well balanced and also had good palatability. Xue et al. (2006) and Turchini et al. (2003) reported similar results in feed efficiency, but Caballero et al. (2002) indicated an increment in FCR value of fish fed diet with a $60 \%$ fish oil substitution by lard.

The biometric data reported in this experiment were similar to those reported by Xue et al. (2006), Turchini et al. (2003) and Caballero et al. (2002). These authors indicated that pork fat did not affect visceral fat and liver size. In carcass values, only moisture content was affected by lard inclusion, reporting a higher value compared with the control group, similar to results observed by Turchini et al. (2003) and Xue et al. (2006) in the substitution of fish oil by pork fat, although fish fed with those diets obtained lower protein and fat content compared with the other treatments, perhaps as a result of the lower digestibility reported with those diets for carnivorous fish like Salmo trutta and Lateolabrax japonicus.

Fatty acids in fish muscle and liver were affected by diets, especially by the higher lard inclusion. In the case of LA, one of the most important precursors for biosynthesis to EPA and DHA, there was a positive accumulation in liver and muscle, and in the case of LNA, the most limiting EFA, there were no significant differences, but it was observed a reduction in its level as a result of pork fat content in experimental diets. Similar results 
were reported by Xue et al. (2006). However, Turchini et al. (2003) reported a lower content of LNA in brown trout fed with pork fat diet compared with fish fed a fish oil diet.

Due to the fatty acid alterations, Martinez-Llorens et al. (2007), Xue et al. (2006), Turchini et al. (2003), Caballero et al. (2002) and Craig and Gatlin (1995) suggested a re-feeding or 'wash out' period to 'normalise' the fatty acid profile of fish fed the alternative lipid sources. As Turchini et al. (2009) quoted, "fish oil replacement in aqua feed is the resultant unavoidable modification of fish fillet fatty acid composition and the consequent loss of the particular health-promoting characteristic associated with the consumption of fish and sea food. These modifications can also affect the sensory qualities of fish fillets and the consumers' perception of farmed fish".

The efficiency of the deposition of EFA especially in ARA, EPA and DHA observed in Fig. 3 was higher as pork fat inclusion increased in experimental diets. This data could be corroborated in a future as a possible capacity of sharpsnout sea bream to bio-convert LA and LNA into ARA, EPA and DHA. This data could be in part supported by the comments of Turchini et al. (2009) who indicated that anadromous and marine species express elongase and desaturase activity and hence the possibility to convert 18:2n-6 and 18:3n-3 to AA and EPA, although they emphasise that these activities are minimal.

The histology showed that sharpsnout sea bream livers responded similarly to experimental diets, with a tendency to accumulate intracellular fat in the case of 0 and $75 \%$ of pork fat diets that caused a reduction in hepatocyte numbers, perhaps these tendency could be due to the species itself as a result of its omnivorous habits (Mena Selles and García García 2002) or to a natural difference in liver morphology that is common in fish not only inter species but also intra-species (Datta Munshi and Dutta 1996). Moreover, according to Turchini et al. (2009), fish are able to accumulate fat in different tissues depending on the species, age and season of the year. To sum up, the results obtained in hepatocytes quantification could not be completely attributed to fish oil replacement.

Besides another important aspect that Hertrampf and Piedad-Pascual (2000) reported is that apparent digestibility of pork fat in rainbow trout (Oncorhynchus mykiss) increased as temperature increased, another point that could reinforce pork fat as alternative oil in Mediterranean species such as sharpsnout sea bream. Those authors also indicated that lard had a high vitamin $\mathrm{E}$ content $\left(22 \mathrm{mg} \mathrm{kg}^{-1}\right)$. Vitamin $\mathrm{E}$ is an antioxidant that is very important to fish health. This coincides with the recommendation of Turchini et al. (2009) to use animal lipids such as pork fat that are rich in saturated fatty acids.

\section{Conclusion}

The substitution of fishmeal by pork fat in sharpsnout sea bream juveniles did not affect the growth or feed efficiency in the 84-day experiment, although it was observed a tendency to diminish fish growth while pork fat inclusion increased. Biometric and carcass analyses were not affected by this animal fat, and only fatty acids exhibited significant differences, although it seemed that the essential fatty acid requirements were met even with the highest substitution of pork fat. The liver histology apparently reflected the omnivorous food habit of the sharpsnout sea bream, presenting an accumulation of intracellular lipids that could induce hepatocyte augmentation and the reduction in quantity per area counted.

Acknowledgments This research was supported by grants from the 'Planes Nacionales de Acuicultura (JACUMAR)' and Consellería de Agricultura Pesca y Alimentación, Valencia, Spain. 


\section{References}

A.O.A.C. (Association of official Analytical Chemists) (1990) Official Methods of Analysis, 15th end. Association of official analytical chemists, Arlington, $1298 \mathrm{pp}$

Benatti P, Peluso G, Niccolai R, Calvani M (2004) Review polyunsaturated fatty acids: biochemical, nutritional and epigenetic properties. J Am Coll Nutr 23(4):281-302

Caballero MJ, Obach A, Rosenlund G, Montero D, Gisvold M, Izquierdo MS (2002) Aquaculture impact of different dietary lipid sources on growth, lipid digestibility, tissue fatty acid composition and histology of rainbow trout, Oncorhynchus mykiss. Aquaculture 214:253-271

Craig SR, Gatlin III DM (1995) Coconut and Beef tallow, but not tricaprylin, can replace menhaden oil in the diet of red drum (Sicaenops ocellatus) without Adversely affecting growth or fatty acid composition. J Nutr 3041-3048

Datta Munshi JS, Dutta HM (1996) Fish morphology: horizon of new research. Science Publishers Inc. Lebanon, New Hampshire. (81-93 pp) 300 pp

Diaz I, García Regueiro JA, Casillas M, De Pedro E (1996) Triglyceride composition of fresh ham fat from Iberian pigs produced with different systems of animal nutrition. Food Chem 55(4):383-387

Food Safety Authority of Ireland (FSAI) 2005 Investigation into levels of dioxins, furans, PCBs, and PBDEs in Irish food 2004. (Cited January 15, 2010) Available from URL: http://www.fsai.ie

Heck NE, Calbert HE (1977) Use of animal fat in formulated diets for yellow perch (Perca flavescens). World Maric Soc 8:787-794

Hertrampf JW, Piedad-Pascual F (2000) Handbook on ingredients for aquaculture feeds. Kluwer Academic Publishers, Dordrecht, The Netherlands

Izquierdo MS, Montero D, Robaina L, Caballero MJ, Rosenlund G, Gines R (2005) Alterations in fillet fatty acid profile and flesh quality in gilthead sea bream (Sparus aurata) fed vegetable oils for a long term period. Recovery of fatty acid profiles by fish oil feeding. Aquaculture 250:431-444

Kotch DE, Pearson AM, Magee WT, Hoefer JA, Schweigert BS (1968) Effect of diet on the fatty acid composition of pork fat. J Anim Sci 27:360-365

Lundebye A-K, Berntssen MHG, Lie O, Ritchie G, Isosaari P, Kiviranta H, Vartiainen T (2004) Dietary uptake of dioxins (PCDD/PCDFs) and dioxin-like PCBs in Atlantic salmon (Salmo salar). Aquacult Nutr 10:199-207

Martinez-Llorens S, Tomás Vidal A. Moñino AV, Pla Torres M, Jover Cerdá M (2007) Effects of dietary soybean oil concentration on growth nutrient utilization and muscle fatty acid composition of gilthead se bream (Sparus aurata L.). Aquacult Res 38:76-81

McFadzen IRB, Coombs SH, Halliday NC (1997) Histological indices of the nutritional condition of sardine, Sardina pilchardus (Walbaum) larvae off the north coast of Spain. J Exp Mar Biol Ecol 212:239-258

Mena Selles C, García García B (2002) Importancia de la proteína vegetable en la dieta natural de poblaciones salvajes de Sargo picudo Diplodus puntazzo (Cetti, 1777); sus implicaciones en el cultivo intensivo. AquaTIC No 17. Available from URL: http://www.revistaaquatic.com/swusyiv/hyml/sty 1705/sargo.htm

O'Fallon JV, Busboom JR, Nelson ML, Gaskins CT (2007) A direct method for fatty acid methyl ester synthesis. Application to wet meat tissues, oils and feedstuffs. J Anim Sci 85:1511-1521

Sargent J, Tacon A (1999) Development of farmed fish: a nutritionally necessary alternative to meat. Proc Nutr Soc 58(2):377-383

Sargent JR, Tocher DR, Bell JG (2002) The lipids. In: Halver JE, Hardy RW (eds) Fish Nutrition. Academic Press, San Diego, pp 181-257

Sheehan D, Hrapchek B (1983) Theory and practice of histotechnology, 2nd edn. Battlelle Press, Columbus

Snedecor G, Cochran W (1971) Statistical methods. The Iowas State University Press, Ames, 592 pp

Turchini GM, Mentasti T, Frøyland L, Orbanc E, Caprinoa F, Morettia VM, Valfre F (2003) Effects of alternative dietary lipid sources on performance, tissue chemical composition mitochondrial fatty acid oxidation capabilities and sensory characteristics in brown trout (Salmo trutta L.). Aquaculture $225: 251-267$

Turchini GM, Toorstensen BE, Ng W-K (2009) Fish oil replacement in finfish nutrition. Rev Aquacult $1: 10-57$

Ventanas S, Ventanas J, Tovar J, García C (2007) Extensive feeding versus oleic acid and tocopherol enriched mixed diets for the production of Iberian dry-cured hams: effect on chemical composition, oxidative status and sensory traits. Meat Sci 77:246-256

Xue M, Luo L, Wu X, Ren Z, Gao P, Yu Y, Pearl G (2006) Effects of six alternative lipid sources on growth and tissue fatty acid composition in Japanese sea bass (Lateolabrax japonicus). Aquaculture 260:206-214

Zhou Q-C, Li C-C, Liu C-W, Chi S-Y, Yang Q-H (2007) Effects of dietary lipid sources on growth and fatty acid composition of juvenile shrimp, Litopenaeus vannamei. Aquacult Nutr 13:222-229 



\section{CAPITULO 9}

Effect of partial inclusion of alternative lipid sources in sharpsnout sea bream.

Enviado a: Fish Physiology and Biochemistry 



\title{
Effect of partial inclusion of alternative lipid sources in sharpsnout sea bream.
}

\author{
Silvia Nogales Mérida, Ana Tomás-Vidal, Silvia Martínez-Llorens, \& Miguel Jover \\ Cerdá.
}

Aquatic Resources Research Group. Animal Science Department. Polytechnic University of Valencia.

Correspondence: Silvia Nogales Mérida, Polytechnic University of Valencia. Camino de Vera, 14. 46071- Valencia (Spain). silvianogales@hotmail.com Tel: 34-96-3877434; Fax 34-96-3877439

\begin{abstract}
Fish oil substitution has been shown to affect not only fatty acid profile and fillet quality but also, hepatic morphology and gonad maturation due to the profile of the raw material used in fish diets. The trial lasted 168 days. 134 sharpsnout sea bream (average weight $105 \mathrm{~g} \pm 21$ ) were distributed in eight fibre tanks. Three almost iso lipidic $(19.32 \% \mathrm{CL})$ and iso proteic $(39.3 \% \mathrm{CP})$ diets were formulated. Fish oil was partially replaced by soybean oil (SO) and pork lard (PL). Fish were fed by hand twice a day. At the end of the trial ten fish per treatment were sacrificed to evaluate corporal differences, fatty acids in fish liver and muscle. Liver histology and organoleptic test were done. No statistical differences were obtained in growth parameters but in feed efficiency fish fed PL presented the highest Feed Conversion Rate and Protein Efficiency Ratio (2.71 and $0.94 \%$ respectively) in relation to the other diets. In biometric analysis were also no statistical differences but in carcass composition fish fed PL presented the lowest CL content $(12.93 \%)$. At the same time fish fed SO diet apparently presented the healthiest liver, hepatocytes better shaped and nuclei not displaced to the cell membrane. Fatty acids exhibited statistical differences in MUFA, PUFA, n-3 HUFA content. But organoleptic test reveal that only $11 \%$ and $14 \%$ of panellists distinguished the odd portion. Beside the atherogenicity and thrombogenicity index were similar in all treatments showing that FO substitution did not affect fillet quality.
\end{abstract}

Keywords: fatty acids, histology, liver, pork lard, sharpsnout sea bream, soybean oil.

\section{Introduction}

Fish oil (FO) is the most rich sources of polyunsaturated fatty acids (PUFA) used in aquaculture production. These fatty acids, well known for their health benefice not only to fish growth and reproduction, but also to human welfare. But, recently Lall (2010) and Turchini et al. (2009) reported that farmed fish, especially those from Europe, contains significantly more organic contaminants than the wild one, attributing to fish meal and oils from that contamination. Based on this data is necessary not only substitute FO by alternative lipid sources based on prices, but also on possible contamination caused by these sources.

In last decades fish oil has been partially or totally substitute with alternative oils such as vegetable oils (rapeseed oils, soybean oil, sunflower oil among others) and animal fats like pork lard, beef tallow and poultry by products in order to reduce fish cost production. This is possible if essential fatty acids requirement are satisfied (Sargent et al., 1999) in marine fish like sharpsnout sea bream.

Most of the alternative oils lacked highly unsaturated fatty acids (HUFA), especially arachidonic acid (C20:4n6), eicosapentaenoic acid (C20:5n3) or docosahexaenoic acid $(\mathrm{C} 22: 6 \mathrm{n} 3)$, that are essential to marine fish. They can not bio-convert from linolenic acid (LNA) to HUFA $\omega 3$ and from linoleic acid (LA) to HUFA $\omega 6$, like mammals and continental fish (Turchini et al. 2009). But, pork fat contains certain amount of arachidonic acid (ARA) (Ruíz et al., 1998; Rodriguez-Carpena et al., 2011). And as 
Glencross (2009) indicated, there is a competitive inhibition between dietary derived LNA or LA for the $\Delta^{6}$ desaturase, enzyme required to bio convert into HUFA, and if the diet already contains arachidonic acid (ARA), this could lead to the conversion into eicosapentaenoic acid (EPA) and docosahexaenoic acid (DHA) more efficiently than to ARA.

There is no report of sharpsnout sea bream fed until commercial weight by alternative oils like soybean oil (SO), rich in MUFA or pork lard (PL) and a comparison of filled and liver fatty acids and liver histology. Besides lipid and fatty acid composition have been identified as major dietary factors that determine gonad development and fecundity (Izquierdo et al. 2001), so it is important to observe how these alternative lipid sources could influence gonad maturation.

Table 1. Ingredients and proximate composition of the experimental diets and biochemical analyses

\begin{tabular}{|c|c|c|c|}
\hline Ingredients $\left(\mathrm{g} \mathrm{kg}^{-1}\right)$ & FO & $\mathrm{SO}$ & PL \\
\hline Fish meal, herring $(5-02-000)^{1}$ & 454 & 454 & 454 \\
\hline Sunflower meal(5-04-739) ${ }^{2}$ & 235 & 235 & 235 \\
\hline Wheat $(4-05-268)^{3}$ & 94 & 94 & 94 \\
\hline Soybean oil (4-07-983) & 0 & 100 & 0 \\
\hline Fish oil (7-08-048) & 157 & 57 & 57 \\
\hline Lard fat & 0 & 0 & 100 \\
\hline Maltodextrin & 50 & 50 & 50 \\
\hline Vitamin $\mathrm{Mix}^{4}$ & 6.3 & 6.3 & 6.3 \\
\hline Vitamin C & 1.5 & 1.5 & 1.5 \\
\hline Mineral Mix ${ }^{5}$ & 2.2 & 2.2 & 2.2 \\
\hline \multicolumn{4}{|c|}{ Proximate composition (\% dry weight) } \\
\hline Dry Matter (DM) & 93.31 & 93.61 & 92.79 \\
\hline Crude protein $(\mathrm{CP})$ & 41.51 & 41.64 & 42.25 \\
\hline Crude lipid (CL) & 20.62 & 21.77 & 19.81 \\
\hline Ash & 10.95 & 10.87 & 10.90 \\
\hline Crude fibre $(\% \mathrm{CF})$ & 4.85 & 4.84 & 4.80 \\
\hline \multicolumn{4}{|l|}{ Calculated values } \\
\hline $\mathrm{N}$-free extract $(\mathrm{NFE})^{6}$ & 22.07 & 20.88 & 22.24 \\
\hline $\mathrm{GE}\left(\mathrm{MJ} \mathrm{kg}^{-1}\right)^{7}$ & 20.53 & 20.93 & 20.30 \\
\hline $\mathrm{CP} / \mathrm{GE}\left(\mathrm{g} \mathrm{MJ}^{-1}\right)$ & 18.97 & 18.85 & 19.31 \\
\hline
\end{tabular}

All analysis was done in the feed nutrition laboratory belonging to Animal Science Department

${ }^{1}$ Fish meal: DM: 93.6\%; CP: 72.9\%; CL: 8.7\%; Ash: 17.0\%; GE: $20.89 \mathrm{Mj} \mathrm{Kg}^{-1}$

${ }^{2}$ Sunflower meal: DM: $91.4 \%$; CP: 38.3\%; CL: 2.2\%; CF: $21 \%$; Ash: $8.0 \%$ NFE: $30.5 \%$; GE: $15.39 \mathrm{Mj}$ $\mathrm{Kg}^{-1}$

${ }^{3}$ Wheat: DM: 88.5\%; CP: 9.1\%; CF: 3.2\%; Ash: 1.5\%; NFE: $84.0 \%$, GE: $17.79 \mathrm{Mj} \mathrm{Kg}^{-1}$

${ }^{4}$ Vitamin mix (values are $\mathrm{g} \mathrm{kg}^{-1}$ except to those in parenthesis): Premix: 20; Choline. 10; DL$\alpha$-tocopherol. 5; ascorbic acid. 5; Premix composition: retinol acetate. (1000000 IU7kg); calciferol. (500 $\mathrm{IUkg}^{-1}$ ); DL- $\alpha$-tocopherol. 10; menadione sodium bisulphite. 0.8; thiamin hydrochloride. 2.3; riboflavin. 2.3; pyridoxine hydrochloride. 15; canocobalamin. 25; nicotinamide. 15; pantothenic acid. 6; folic acid. 0.65; biotin. 0.07; ascorbic acid. 75; inositol. 15; betaine. 100; polypeptides. 12. (Source: Dibaq-Diproteg).

${ }^{5}$ Mineral mix: Zn. 5; Se. 0.02; I. 0.5; Fe. 0.2; Cuo. 15; Mg. 5.75; Co. 0.02; Met. 0.2; Cys. 0.8; Lys. 1.3; Arg. 0.6; Phe. 0.4; Try. 0.7; excpt. to 1000g (Source: Dibaq-Diproteg).

${ }^{6} \% \mathrm{NFE}=100-\% \mathrm{CP}-\% \mathrm{CL}-\%$ Ash-\%CF.

${ }^{7} \mathrm{GE}$ : Gross energy: Calculated using: $23.9 \mathrm{~kJ} \mathrm{~g}^{-1}$ proteins, $39.8 \mathrm{~kJ} \mathrm{~g}^{-1}$ lipids and $17.6 \mathrm{~kJ} \mathrm{~g}^{-1}$ carbohydrates. 
Moreover, Bell and Waagbø (2008) indicated that health benefits of fish consumption, related to the n-3 HUFA content, are now widely recognised and it is important that aquaculture maintains a healthy product image by producing sea food that is comparable with those from capture fisheries. Because the reduction of EPA and DHA consumption has been decreasing in the last 50 years, and has contributed to the increasing incidence of atherosclerosis, hypertension, metabolic syndrome $\mathrm{X}$, obesity, collagen vascular diseases and, possibly cancer (Das, 2006).

Considering all the aspect before mention this trial was designed to evaluate the effect of fish oil replacement by soybean oil and pork lard, on fish growth, muscle and liver fatty acids profile, histological alteration in liver and gonads, meat quality and organoleptic acceptance.

\section{Material and methods}

\section{Animal housing}

A total of 136 specimens (average weight $105 \mathrm{~g} \pm 21$ ) were distributed in eight fibre cylindrical tanks (750 1 of capacity) part of a recirculated water system. There were from 17 fish per tank, amounting to an initial biomass of $14 \mathrm{~kg}$. The fish were proceeding from other feeding experiment and they were feed with the control diet (FO, Table 1) a month before the experiment started. The trial was done in the laboratory of Aquaculture of Science Department of the Polytechnic University of Valencia. The trial lasted 168 days (June $9^{\text {th }}$ to November $24^{\text {th }}$ ).

Water temperature and dissolved oxygen were recorded daily. The average temperature during the trial was $24.0 \pm 1.5{ }^{\circ} \mathrm{C}$; oxygen $6.9 \pm 0.5 \mathrm{mg} \mathrm{L}^{-1}$. The other parameters were recorded three times a week. Salinity was $26.6 \pm 2.2 ; \mathrm{pH}$ values were $6.4 \pm 0.1 ; \mathrm{NO}_{2}{ }^{-}$ values was $0.3 \pm 0.2 ; \mathrm{NH}_{4}{ }^{+}$was $0.2 \pm 0.3 ; \mathrm{NO}_{3}{ }^{-}$was $49.4 \pm 22.9$. Photoperiod was natural and all tanks had similar light conditions.

\section{Feed and feeding}

Composition of the ingredients used in the experimental diets is shown in Table 1. Three almost isonitrogenous $\left(418 \mathrm{~g} \mathrm{~kg}^{-1}\right)$ and isoenergentic diets $\left(207.3 \mathrm{~g} \mathrm{~kg}^{-1}\right)$ were formulated. Fish oil was the only lipid source added to the control diet (FO), in SO diet $50 \%$ of FO was substituted by soybean oil and in PL diet, $50 \%$ of FO was also replaced by pork lard. Additionally, sunflower meal was included at $235 \mathrm{~g} \mathrm{~kg}^{-1}$ in all diets following results obtained in previous trial (Nogales-Mérida et al. 2010). Fatty acids profiles of experimental diets are shown in Table 2. Diets were prepared by cookingextrusion processing with a semi-industrial twin-screw extruder (CLEXTRAL BC-45, St. Etienne, France). The processing conditions were as follows: $100 \mathrm{rpm}$ speed screw, $110{ }^{\circ} \mathrm{C}$ temperature, $30-40 \mathrm{~atm}$ pressure and 2, and $3 \mathrm{~mm}$ diameter pellets, according of size fish. Experimental diets were assayed in triplicate groups.

Fish were fed by hand twice a day (9:00 and 15:00) from Monday through Friday and on Saturday only at noon. Pellets were distributed slowly allowing all fish to eat. 
Table 2. Fatty acids profiles (wt \%) of experimental diets and row oils used in this trial.

\begin{tabular}{|c|c|c|c|c|c|c|}
\hline \multirow[b]{2}{*}{$\%$ Acidos Grasos Detectados } & \multicolumn{3}{|c|}{ Row oils } & \multicolumn{3}{|c|}{ Experimental diets } \\
\hline & $\begin{array}{c}\text { Fish } \\
\text { Oil }\end{array}$ & $\begin{array}{c}\text { Soybean } \\
\text { Oil }\end{array}$ & $\begin{array}{l}\text { Pork } \\
\text { lard }\end{array}$ & FO & $\mathrm{SO}$ & $\mathrm{PL}$ \\
\hline Myristic Acid (C14:0) & 4.64 & - & 1.35 & 4.98 & 2.48 & 3.13 \\
\hline Pentadecanoic Acid (C15:0) & 0.51 & - & - & 0.58 & 0.24 & 0.28 \\
\hline Palmitic Acid (C16:0) & 15.68 & 10.96 & 23.29 & 18.20 & 14.62 & 23.20 \\
\hline Stearic Acid (C18:0) & 3.76 & 3.20 & 10.37 & 4.58 & 4.08 & 11.35 \\
\hline Arachidic Acid (C20:0) & 0.24 & - & - & 0.26 & - & - \\
\hline Behenic Acid (C22:0) & 0.17 & - & - & 0.24 & 0.34 & 0.15 \\
\hline Lignoceric Acid (C24:0) & 0.07 & - & - & 0.13 & 0.16 & 0.08 \\
\hline$S F A$ & 25.07 & 14.16 & 35.01 & 28.96 & 21.91 & 38.20 \\
\hline Palmitoleic Acid (C16:1) & 5.79 & - & 2.19 & 5.91 & 3.02 & 3.95 \\
\hline Cis-vaccenic 18:1(n-7) & 4.32 & - & - & 4.07 & 3.31 & 4.87 \\
\hline Oleic Acid (C18:1n9c) & 19.29 & 25.03 & 51.66 & 15.78 & 19.17 & 24.35 \\
\hline cis-11-Eicosenoic Acid (C20:1) & 4.85 & - & - & 3.89 & 1.54 & 1.81 \\
\hline Erucic Acid (C22:1n9) & 5.08 & - & - & 3.75 & 1.45 & 1.33 \\
\hline Nervonic Acid (C24:1) & 0.82 & - & - & 0.64 & 0.42 & 0.36 \\
\hline$M U F A$ & 40.16 & 25.03 & 53.84 & 34.04 & 28.91 & 36.68 \\
\hline Linoleic Acid (C18:2n6c) & 5.74 & 54.60 & 9.25 & 6.38 & 30.47 & 9.11 \\
\hline Linolenic Acid (C18:3n3) & 2.15 & 6.15 & 1.21 & 1.49 & 3.63 & 1.22 \\
\hline g-Linolenic Acid (C18:3n6) & 0.19 & - & - & 0.16 & 0.11 & 0.09 \\
\hline Cis-Eicosadienoic Acid (C20:2n6) & 2.07 & - & - & 1.98 & 0.95 & 1.13 \\
\hline cis-Eicosatrienoic Acid (C20:3n3) & 1.20 & - & - & 0.22 & 0.09 & 0.16 \\
\hline cis-Eicosatrienoic Acid (C20:3n6) & 0.20 & - & - & 0.17 & 0.07 & 0.11 \\
\hline Arachidonic Acid (C20:4n6) & 0.94 & - & 0.08 & 1.22 & 0.68 & 0.71 \\
\hline cis-Eicosapentaenoic Acid (C20:5n3) & 7.87 & - & - & 8.89 & 5.18 & 4,83 \\
\hline cis-Docosadienoic Acid (C22:2) & 0.98 & - & - & 0.74 & 0.32 & 0.33 \\
\hline cis-Docosapentaenoic acid 22:5(n-3) & 2.25 & - & - & 2.05 & 1.05 & 1.04 \\
\hline cis-Docosahexaenoic Acid (C22:6n3) & 10.44 & & - & 12.77 & 6.17 & 5.64 \\
\hline$P U F A$ & 34.02 & 60.75 & 10.54 & 36.05 & 48.73 & 24.36 \\
\hline n-3 HUFA & 20.56 & 0 & 0 & 23.71 & 12.40 & 11.51 \\
\hline n3 & 23.90 & 6.15 & 1.21 & 25.41 & 16.13 & 12.88 \\
\hline n6 & 9.14 & 54.60 & 9.34 & 9.90 & 32.29 & 11.15 \\
\hline $\mathrm{n} 3 / \mathrm{n} 6$ & 2.61 & 0.11 & 0.13 & 2.57 & 0.50 & 1.15 \\
\hline EPA/DHA & 0.75 & & & 0.70 & 0.84 & 0.86 \\
\hline
\end{tabular}

\section{Sampling procedure}

Fish were weighed at the beginning of the experiment and every 28 days until the end of the trial. Every day feed intake was monitored for all experimental groups. The effects on growth were determined by evaluating a number of growth and nutrient utilization indexes, including weight gain, specific growth rate (SGR), feed conversion ratio (FCR) and protein and lipid productive values (PPV, LPV) as well as the survival percentage. At the beginning of the experiment 5 fish were collected for corporal analysis and at the end of the experiment 10 fish per treatment were collected for corporal and biometric 
analysis. Liver, guts and gonads of 5 fish per treatment were collected for histological analysis. 5 fish per treatment were sacrificed for sensory analysis.

\section{Analytical methods}

Chemical analyses of the dietary ingredients were determinated prior to diet formulation. Diets and theirs ingredients (Table 1 and 2) as well as the whole fish were analysed according to AOAC (1990) procedures: dry matter $\left(105{ }^{\circ} \mathrm{C}\right.$ to constant weight), ash (incinerated at $550{ }^{\circ} \mathrm{C}$ to constant weight), and crude protein ( $\mathrm{N} \mathrm{x} \mathrm{6.25)} \mathrm{by}$ the Kjeldahl method after an acid digestion (Kjeltec 2300 Auto Analyser, Tecator Höganas, Sweden), crude lipid extracted with methyl-ether (Soxtec 1043 extraction unit, Tecator) and crude fibre by acid and basic digestion (Fibertec System M., 1020 Hot Estractor, Tecator). All analyses were performed in triplicate.

Fatty acid methyl esters (Fame) of total lipids were prepared directly as previously described O'Fallon et al. (2007). Fame was done with row material, experimental diets and five subsamples of liver and muscles of each treatment. Fame analysis was performed in a Focus Gas Chromatograph (Thermo, Milan, Italy) equipped with a split/splitless injector and a flame ionization detector. The separation of methyl esters was performed in a fused silica capillary column $\mathrm{SP}^{\mathrm{TM}} 2560$ (Supelco, PA, USA) (100 $\mathrm{m} \times 0.25 \mathrm{~mm} \times 0.2 \mu \mathrm{m}$ film thickness). The carrier gas was Helium at a linear velocity of $20 \mathrm{~cm} / \mathrm{seg}$. The samples were injected with a split ratio of $1 / 100$. The initial oven temperature was set at $140{ }^{\circ} \mathrm{C}$ held for $5 \mathrm{~min}$ and increased to 240 at $4{ }^{\circ} \mathrm{C} / \mathrm{min}$ and finally maintained at that temperature for $30 \mathrm{~min}$. Both detector and injector temperatures were set at $260{ }^{\circ} \mathrm{C}$. The individual fatty acids were identified by comparing their retention times with standards of fatty acid methyl esters supplied by Supelco (PA, USA).

\section{Fillet quality and sensory analysis}

Fish were filled and skinned obtaining two fillets that were vaccum-packed in plastic bags and kept at $-20^{\circ} \mathrm{C}$ until the sensory analysis were done.

Colour measurements in the CIELAB space (lightness, $L^{*}$; redness, $a^{*}$ and yellowness, $b^{*}$, CIE 1976) were taken on the inside fillet portion, using a Minolta CR-300 chromometer (Minolta Camera, Osaka, Japan) which gave the average of three measurements of $L^{*}, a^{*}$ and $b^{*}$ at each point where the instrument was placed, using an $8 \mathrm{~mm}^{2}$ opening with an incidence angle of $0^{\circ}$. The illuminate was D65.

The effect of diets on sensory properties of filleted fish was studied comparing fish fed control diet with fish fed SO and LF diets, respectively, in both trials. The triangle test following the ISO-4120 (1983) standard was performed in two sessions by forty panellists not trained.

Twenty fillets from the control group and another twenty from an experimental group were used. They were cooked at $60^{\circ} \mathrm{C}$ during $12 \mathrm{~min}$, and then cut into 9 equally sized, after that they were wrapped into three-digit number coded aluminium foil pieces; they were organized as 20 angle probes, two corresponding to 3 possible combinations. The pieces were kept approximately at $40^{\circ} \mathrm{C}$ in thermo stated boxes during the test.

\section{Histological analysis}


Liver and gonads collected were fixed in phosphate buffered formalin (4\% $\mathrm{pH} 7.4)$ and then transfer to $70 \%$ ethanol for storage until processing. All formalin fixed tissues were routinely dehydrated in ethanol, equilibrated in ultraclear and embedded in paraffin according to standard histological techniques. Longitudinal sections (approximately $5 \mu \mathrm{m}$ thick) of anterior, mid and posterior intestines were cut and stained with haematoxylin and eosin (HE). Processing of the tissues was done at the Histology section of the Animal Science Department of the Polytechnic University of Valencia (Spain). Blinded histological examination was performed by light microscopy (Nikon Phase Contrast 090 Dry Japan MJVS). ). Tissue morphology was evaluated according to McFadzen et al. (1997) criteria in addition to quantification of hepatocytes to observe possible alterations revealed through differences in the hepatocyte condition or hepatic cell morphology. Gonads development was done according to standard methods.

\section{Statistical analysis}

Growth data and nutritive parameters were treated using multifactor analysis of variance (ANOVA), introducing the initial live weight as covariate (Snedecor and Cochran 1971). Newman-Keuls test was used to assess specific differences among diets at 0.05 significant levels (Stat graphics, Statistical Graphics System, Version Plus 5.1, Herndon, Virginia, USA). Hepatocytes quantification was analysed by One-Way ANOVA and McFadzen et al. (1997) and gonads development criteria was done using a cross tabulation and Chi-Square contrast $\left(\mathrm{X}^{2}\right)$ methodology.

\section{Results}

In Table 2, the Fatty acids analysis revealed the present of the different oil sources replaced; PL diet presented the highest percentage in C16:0 (23.2\%) and C18:0 $(11.35 \%)$, at the same time SO diet was rich in C18:2n6 (30.47\%) and C18:3n3 (3.63\%) in relation with the other two diets, on the contrary PL diet exhibited the highest C18:1n9c (24.35\%) Comparing ARA, EPA and DHA content in all diets there was observed a markedly reduction, almost the half on these essential fatty acids in SO and PL diets compared to FO.

Similar fish survival percentage was reported among treatments (FO: $94.0 \%$; SO: $96.1 \%$ and PL: $96.2 \%$ ).

At the end of the trial there were not statistical differences in growth parameters (Table 3 ) among treatments neither in final weight (Fw), SGR nor in TCG. In feed efficiency, fish fed with PL presented the highest FCR (2.71), FI (1.31) as well as the lowest PER $(0.94)(\mathrm{P}<0.05)$.

Corporal analysis results did not reflect statistical differences in any parameter measure (Table 4). At the same time carcass composition (Table 5) presented statistical differences in moisture and crude lipid (CL) content being fish fed control diet that obtained the lowest moisture (63.69\%) and the highest CL (14.56\%). Crude protein and ash were not altered by FO substitution. Gross energy efficiency (GEE) and crude protein efficiency $(\mathrm{CPE})$ did not present statistical differences $(\mathrm{P}<0.05)$. 
Table 3. Effect of lipid substitution on growth performance of Diplodus puntazzo.

\begin{tabular}{lcccccccc}
\hline Treatment & IBW & FBW & TCG $^{1}$ & SGR $^{2}$ & FCR $^{3}$ & FI $^{4}$ & PER $^{5}$ & Survival \\
\hline FO & 109.7 & 241.5 & 0.87 & 0.59 & $2.51^{\mathrm{b}}$ & 1.35 & $1.02^{\mathrm{b}}$ & 93.95 \\
& \pm 5.85 & \pm 11.47 & \pm 0.06 & \pm 0.03 & \pm 0.05 & \pm 0.05 & \pm 0.02 & \pm 2.13 \\
\hline SO & 104.9 & 257.0 & 0.95 & 0.54 & $2.42^{\mathrm{b}}$ & 1.45 & $1.05^{\mathrm{b}}$ & 96.07 \\
& \pm 4.78 & \pm 8.88 & \pm 0.04 & \pm 0.02 & \pm 0.04 & \pm 0.04 & \pm 0.02 & \pm 1.74 \\
\hline PL & 102.6 & 248.6 & 0.90 & 0.61 & $2.72^{\mathrm{a}}$ & 1.57 & $0.94^{\mathrm{a}}$ & 96.17 \\
& \pm 4.78 & \pm 9.13 & \pm 0.03 & \pm 0.02 & \pm 0.04 & \pm 0.04 & \pm 0.02 & \pm 1.74
\end{tabular}

Values are the mean \pm S.E.M $(n=3)$. The same letters are not different $(\mathrm{P}>0.05)$. Newman-Keuls test. Initial weight in each phase was considerer as covariable for live weight and SGR.

IBW= initial body weight; FBW = final body weight

${ }^{1}$ Thermal Growth Coefficient $\left(\mathrm{TGC}^{*} 10^{-3}\right)=1000 *\left[\mathrm{Fw}^{1 / 3}-\mathrm{Iw}^{1 / 3}\right] /\left(\mathrm{T}^{\mathrm{o}}-\right.$ minimum $\mathrm{T}^{\mathrm{o}}$ to feed $)$.

${ }^{2}$ Specific growth rate $\left(\%\right.$ day $\left.^{-1}\right),(\mathrm{SGR})=100 \mathrm{x} \ln ($ final weight $/$ initial weight $) /$ days

${ }^{3}$ Feed Conversion ratio, $\mathrm{FCR}=$ feed intake $(\mathrm{g}) /$ Biomass gain $(\mathrm{g})$

${ }^{4}$ Protein efficiency ratio $(\mathrm{PER})=$ Biomass gain $(\mathrm{g}) /$ protein intake $(\mathrm{g})$

${ }^{5}$ Feed Intake $\left(\mathrm{g} 100 \mathrm{~g} \mathrm{fish}^{-1} \mathrm{day}^{-1}\right), \mathrm{FI}=100 \mathrm{x}$ feed intake $(\mathrm{g}) /$ average biomass $(\mathrm{g}) \mathrm{x}$ days

Fatty acids profiles were analysed in fillets and liver to observe how partial substitution affected them (Fig. 1). In saturate fatty acids (SFA), only C14:0 were affected by oil substitution reducing the quantity in SO (2.66\%) and LF $(2.81 \%)$. In mono unsaturated fatty acids (MUFA) there were reported in C16:1 and SO presented the lower value (4.07\%). Comparing in general the PUFA content, PL diet exhibited the lower content (32.01\%), but in C18:2n6c as well as in C18:3n3 fish fed SO diet presented the highest value $(19.25 \%$ and $2.11 \%$ respectively). In n-3 HUFA the highest value was obtained with fish fed FO (26.98\%) in relation to the other treatments. Fish fed SO diet obtained the highest EPA (7.37\%) as well as in C22:6n3, even thought there were no statistical differences among treatments FO diet reflected the higher value (15.79\%), but if $n 3 / n 6$ relation are compared SO diet obtained the lower value $(0.99 \%)$.

Table 4. Biometric analysis of sharpsnout sea bream fed with the 3 experimental diets at the end of the trial.

\begin{tabular}{lcccc}
\hline & FO & SO & LF & SEM \\
\hline $\mathrm{CF}^{\mathrm{a}}$ & 2.26 & 2.32 & 2.26 & 0.09 \\
$\mathrm{DP}^{\mathrm{b}}$ & 79 & 77 & 76 & 0.01 \\
$\mathrm{VSI}^{\mathrm{c}}$ & 7.72 & 8.17 & 9.39 & 0.77 \\
$\mathrm{MFI}^{\mathrm{d}}$ & 1.67 & 1.40 & 1.77 & 0.23 \\
$\mathrm{HSI}^{\mathrm{e}}$ & 1.59 & 1.67 & 2.36 & 0.28 \\
$\mathrm{GSI}^{\mathrm{f}}$ & 1.48 & 1.01 & 1.18 & 0.34 \\
\hline
\end{tabular}

Values are the mean \pm S.E.M $(n=5)$. The same letters are not different $(\mathrm{P}>0.05)$. Newman-Keuls test.

${ }^{a}$ Condition Factor $(\mathrm{CF})=\left[\right.$ body weight $(\mathrm{g}) /$ total length $\left.(\mathrm{cm})^{3}\right]$ x 100.

${ }^{\mathrm{b}}$ Dress out percentage (DP) $=100 \mathrm{x}$ [total fish weight $(\mathrm{g})$ - visceral weight $(\mathrm{g})$-head weight $\left.(\mathrm{g})\right] /$ fish weight $(\mathrm{g})$

${ }^{\mathrm{c}}$ Viserosomatic index $(\mathrm{VSI})=100 \mathrm{x}$ [visceral weight $(\mathrm{g}) /$ fish weight $\left.(\mathrm{g})\right]$

${ }^{\mathrm{d}}$ Mesenteric fat index (MF) $=[$ mesenteric fat weight $(\mathrm{g}) /$ body weight $(\mathrm{g})]$ x 100.

${ }^{\mathrm{e}}$ Hepatosomatic index $(\mathrm{HSI})=[$ liver weight $(\mathrm{g}) /$ body weight $(\mathrm{g})] \times 100$.

${ }^{\mathrm{f}}$ Gonadosomatic index $(\mathrm{GSI})=100 \mathrm{x}$ [gonads weight $(\mathrm{g}) /$ fish weight $(\mathrm{g})$ ]

In liver content, SFA, MUFA and n-3 HUFA were not affected by experimental diets, only PUFA presented statistical differences being fish fed PL diet that presented the lowest value (32.01\%). Fish fed SO diet presented the highest value in LA and LNA 
(17.30\% and $1.66 \%$ respectively) but in EPA the lowest value were reported in fish fed the SO diet. In the relation between $\mathrm{n} 3 / \mathrm{n} 6$ fish fed FO diet exhibited the highest value $(2.66 \%)(\mathrm{P}<0.05)$.

The relation between percentage of EFA in liver and experimental diets (Fig 2a) there was only significant differences in LA, being fish fed SO diet that presented the lowest value on the contrary in LNA the highest value. But in the relation between muscle and experimental diets (Fig. 2b) there was only statistical difference in LA, being fish fed SO diet that presented the lowest value.

Sharpsnout sea bream liver in the three groups tested shown steatosis, most markedly in FO and PL at the same time pancreatic tissue were degenerating showing fat inclusion. In control group were observed mononuclear leucocytes as well as sinusoids congested with red blood cells. Focal necrosis of hepatic tissue as well as pancreatic tissue were observed in all treatments specially in PL. Bile duct and blood vessels presented a gradual degeneration specially in group of fish fed with the PL (Fig. 3). Nevertheless it was observed in part of each tissue analysed some hepatocytes and acinar cells almost histological normal. It seemed that the degeneration observed were gradually affecting fish liver, especially in PL, followed by control group.
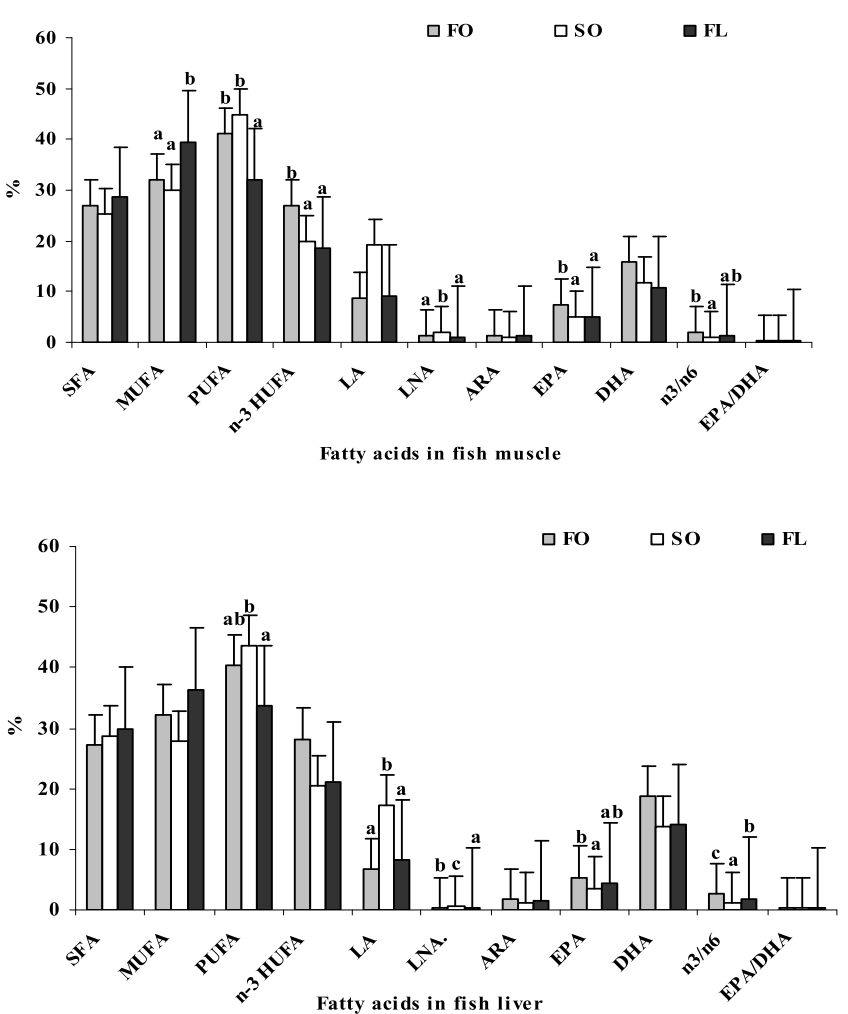

Figure 1. Essential fatty acids in muscle and liver of $D$. puntazzo at the end of the experimental period. Different superscript letters denote significant differences within row $(\mathrm{P}<0.05)$. Five replicates per treatment were analysed.

Comparing all analysis reported above with hepatocytes quantification there is a relation being fish fed PL $(746.4 \pm 23.6)$ and FO $(694.8 \pm 25.1)$ that obtained the higher quantity of cells (Table 6) $(\mathrm{P}<0.05)$. Hepatocytes of fish fed with LF showed a degenerate nuclei and cytoplasm in comparison with fish fed with SO or FO diet. 
Comparing gonads maturation, (Fig. 4) in all fish sacrificed for histological analysis, just a fish did not exhibit visible gonad, the rest (29 fish) presented mature gonads, male had gonad maturation on level V or VI and female showed mature oocytes even atrecic according with histological examination. Another data to consider was the comparison between male and female final weight according to biometric analysis, there were no statistical differences among treatments and sex, but female weight was higher $(261.1 \pm 15.5 \mathrm{~g})$ in relation to male weight $(224.6 \pm 10.6 \mathrm{~g})$.

Table 5. Carcass composition of sharpsnout sea bream

\begin{tabular}{lllllll}
\hline Treat & $\begin{array}{l}\text { Moist. } \\
(\%)\end{array}$ & $\begin{array}{l}\text { CP }(\% \\
\text { ww })\end{array}$ & $\begin{array}{l}\text { CL } \\
(\% \mathrm{ww})\end{array}$ & $\begin{array}{l}\text { Ash } \\
(\% \mathrm{ww})\end{array}$ & GEE & CPE \\
\hline FO & $63.69^{\mathrm{a}}$ & 17.85 & $14.56^{\mathrm{a}}$ & 4.04 & 19.77 & 18.98 \\
& \pm 0.38 & \pm 0.21 & \pm 0.37 & \pm 0.15 & \pm 0.84 & \pm 5.07 \\
SO & $64.65^{\mathrm{ab}}$ & 17.70 & $13.81^{\mathrm{ab}}$ & 3.74 & 16.69 & 19.27 \\
& \pm 0.31 & \pm 0.17 & \pm 0.30 & \pm 0.12 & \pm 0.69 & \pm 4.14 \\
$\mathrm{PL}$ & $65.03^{\mathrm{b}}$ & 17.61 & $12.93^{\mathrm{b}}$ & 3.88 & 18.62 & 23.41 \\
& \pm 0.31 & \pm 0.17 & \pm 0.30 & \pm 0.12 & \pm 0.69 & \pm 4.14 \\
\hline
\end{tabular}

Values are the mean \pm S.E.M $(n=3)$. The same letters are not different $(P>0.05)$. Newman-Keuls test. ${ }^{\mathrm{y}}$ Crude protein efficiency, CPE $(\%)=$ Increment of protein corporally $(\mathrm{g}) \times 100 /$ protein ingestion $(\mathrm{g})$

${ }^{\mathrm{z}}$ Gross energy efficiency, GEE (\%) = Increment of energy corporally (kJ) x 100 / energy ingestion (kJ)

On triangular tests done with FO and SO only $13.59 \%$ of panellists found differences between the fillets proved, but in the test done between FO and PL the percentage reduced, being only $10.76 \%$ of panellists that could only recognize the odd one. In colorimetric values there were no differences among groups. At the same time in fillet weight fresh, loss by cooking and Fillet Yield (FY) there was also no significant differences among groups. Besides atherogenicity and trombogenicity index did not present statistical differences among treatments (Table 7).

\section{Discussion}

Sharpsnout sea bream growth parameters were not statistically affected by FO replacement, although fish did not reach final weight expected in this experiment, nevertheless there was observed an increment in growth parameters with the alternative oils. Similar results were reported by Piedecausa et al. (2007) in sharpsnout sea bream fingerlings attributing these results to the omnivorous habit of this specie. In comparison to Benedito Palos et al. (2008) and Martinez-Llorens et al. (2007) who reported a decreasing final weight in gilthead sea bream, while fish oil replacement increased. Although Fountoulaki et al. (2009) did not reported statistical differences among $S$. aurata fed with FO and different diets partially substitute by vegetable oils such as soybean oil (SO), palm oil (PO) and rapessed oil (RO). Only pork lard inclusion affected feed efficiency reporting the worst values in FCR and PER. Similar results Xue et al. (2006) reported in Lateolabrax japonicus fed with PL diet. On the contrary Caballero et al. (2002) reported higher FCR in Oncorhynchus mykiss fed with a mix of $\mathrm{PL}$, olive oil and fish oil in relation to other experimental diets.

Alternative oils did not cause statistical differences in corporal parameters, although HSI in fish fed with PL was higher in relation to fish fed with FO and SO diets. On the other hand Piedecausa et al. (2007) reported a higher value in fish fed with SO diet in relation to FO diet and lindseed oil replacement attributing these differences to the 
higher content of LA in SO diet. But Xue et al. (2006) did not report statistical differences in L. japonicus fed with different experimental diets. When the experiment ended D. puntazzo was in reproductive period showing a higher GSI especially fish fed FO diet. According to Papadaki et al. (2008) sharpsnout sea bream reproduction period usually start at the end of September and last until the end of December. Gonadal development of sharpsnout sea bream could cause a reduction of final fish growth during the period September-October; similar problem was reported by Mørkøre et al. (2007) during the experimental period of Gadus morhua. Like in this study no significant differences in length at first maturity was found between sexes by Pajuelo et al. (2008).

Table 6. Quantification of hepatocytes in the liver of Sharpsnout sea bream fed with the experimental diets.

\begin{tabular}{|c|c|c|c|c|c|c|c|c|c|c|c|c|}
\hline \multirow[t]{3}{*}{$\mathrm{N}^{\mathrm{o}}$ Hepatocytes } & \multicolumn{4}{|c|}{$\begin{array}{c}\text { FO } \\
694.8 \pm 25.1^{\mathrm{ab}}\end{array}$} & \multicolumn{4}{|c|}{$\begin{array}{c}\mathrm{SO} \\
746.4 \pm 23.6^{\mathrm{b}}\end{array}$} & \multicolumn{4}{|c|}{$\begin{array}{c}\mathrm{PL} \\
656.1 \pm 23.6^{\mathrm{a}}\end{array}$} \\
\hline & \multicolumn{3}{|c|}{ Liver nuclei } & \multicolumn{3}{|c|}{$\begin{array}{c}\text { Liver hepatocyte } \\
\text { cytoplasm }\end{array}$} & \multicolumn{3}{|c|}{$\begin{array}{l}\text { Hepatocyte } \\
\text { vacuolation }\end{array}$} & \multicolumn{3}{|c|}{$\begin{array}{l}\text { Pancreatic } \\
\text { acinar cells }\end{array}$} \\
\hline & 1 & 2 & 3 & 1 & 2 & 3 & 1 & 2 & 3 & 1 & 2 & 3 \\
\hline FO & 4 & 1 & - & 1 & 4 & - & 2 & 3 & - & 2 & 3 & - \\
\hline $\mathrm{SO}$ & 4 & 1 & - & 2 & 3 & - & 2 & 3 & - & 4 & 1 & - \\
\hline PL & 2 & 2 & 1 & 1 & 2 & 2 & 1 & 2 & 2 & 1 & 3 & 1 \\
\hline P-value & \multicolumn{3}{|c|}{$0.0710^{*}$} & \multicolumn{3}{|c|}{$0.0360 * *$} & \multicolumn{3}{|c|}{0.1117} & \multicolumn{3}{|c|}{0.1436} \\
\hline
\end{tabular}

1 (Healthy) 2. (Intermediate) 3 (Degraded)

Different superscript letters denote significant differences within row $(\mathrm{P}<0.05)$.

- Stastistical differences in $95 \%$ for $\mathrm{X}^{2}$

Five replicates per treatment were analysed.

${ }^{1}$ Hepatocytes / $125000 \mu \mathrm{m}^{2}$

Sharpsnout sea bream fed with pork lard diet presented lower crude lipid content and the higher moisture, similar results reported Piedecausa et al. (2007) in relation to fish fed FO and SO diet, although Xue et al. (2006) who partially replaced FO by PL, SO and other lipid sources to feed Lateolabrax japonicus found significant differences in CL content especially in fish fed SO inclusion. On the contrary Martino et al. (2003) reported a higher lipid content in surubim fed with PL diet and a lower crude lipid content in fish fed with SO diet. These results could suggest that lipid content in fish carcass would be related to fish habits.
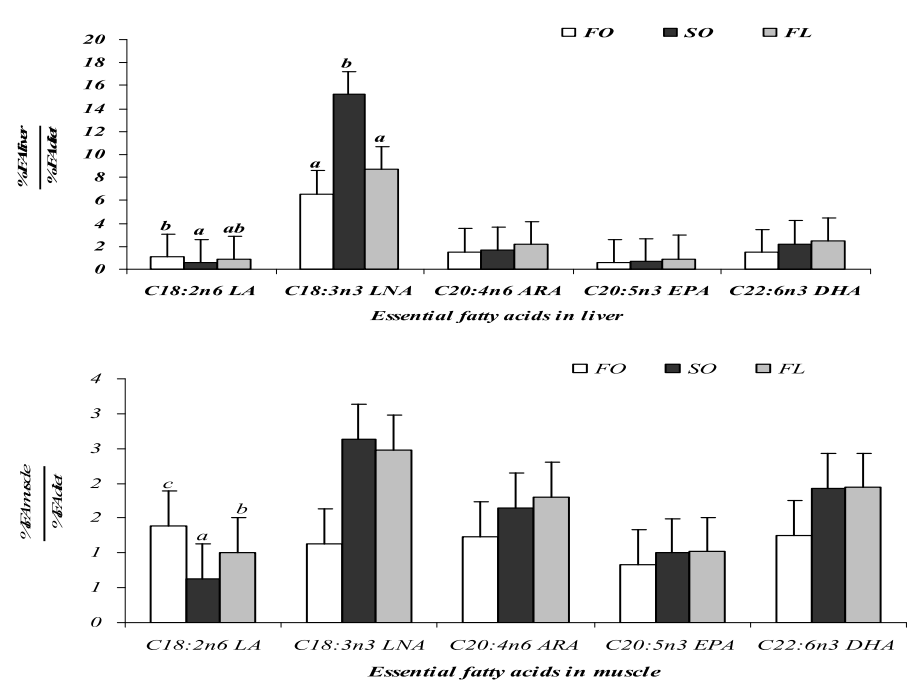
Figure 2. The relation between percentage of fatty acids in muscle (a) and liver (b) of sharpsnout sea bream and experimental diets; Linoleic acids (LA C18: 2n6); Linolenic acids (LNA C18: 3n3), Eicosapentaenoic acids (EPA C20: 5n3) and docosahexaenoic acids (DHA C22: 6n3). Data are the means $(\mathrm{n}=5) \pm$ SEM. Different letters denote statistical differences $\mathrm{P}<0.05$.

Fatty acids values of muscle and liver of sharpsnout sea bream at the end of the experimental period showed the addition of alternative oils, similar results were described by Almaida-Pagan et al. (2007), Fountoulaki et al. (2009), Martínez-Llorens et al. (2007), Xue et al. (2006) and Martino et al. (2002). Turchini et al. (2009) also indicated that the most significant modifications to the fatty acid composition of fish tissues are relative to an increase in the $\mathrm{C}_{18}$ PUFA content (particularly LA), that is so abundant in vegetal and animal terrestrial oils, they consider LA content has a negative effect on fish flesh quality that could significantly affect the consumer perception of aquaculture products. Moreover, Uysal et al. (2006) have reported a decrease in the amount of PUFA and MUFA due to gonad maturation; these authors also mention that during vitellogenesis females can also mobilise stored precursors (LA, LNA) for fatty acids of n-3 and n-6 family for gonad maturation. In male case oleic acid and LNA may decreased on account of the preferential utilisation for testis development, this could cause also a diminish of these fatty acids in sharpsnout sea bream due to the reproduction period where they were collected.

Aside all the aspect already mention, Turchini et al. (2009) indicated that fatty acid composition of fish is dependent on different factors, other than dietary fatty acid composition, digestibility, transport and uptake, elongation and desaturation processes and $\beta$-oxidation of fatty acids will affect the membrane and deposit lipid composition. In general lipids are well digested by fish (Olsen \& Ringø 1997). However, it is also known that individual fatty acids are absorbed at different rates (Turchini et al. 2009) and in part FA absorption would depend on lipase content in fish gastrointestinal tract and in the case of sharpsnout sea bream, Tramati et al. (2005) had found abundant content of protease, amylase and lipase, showing its omnivorous habits. Considering the abundant lipase content, according to Tramati et al. (2005), and comparing the percentage of essential fatty acids (ARA, EPA and DHA) especially in fish muscle (Figure 2) in relation to experimental diets an elongation and desaturation processes could be the cause that sharpsnout sea bream did not present significant differences among treatments.
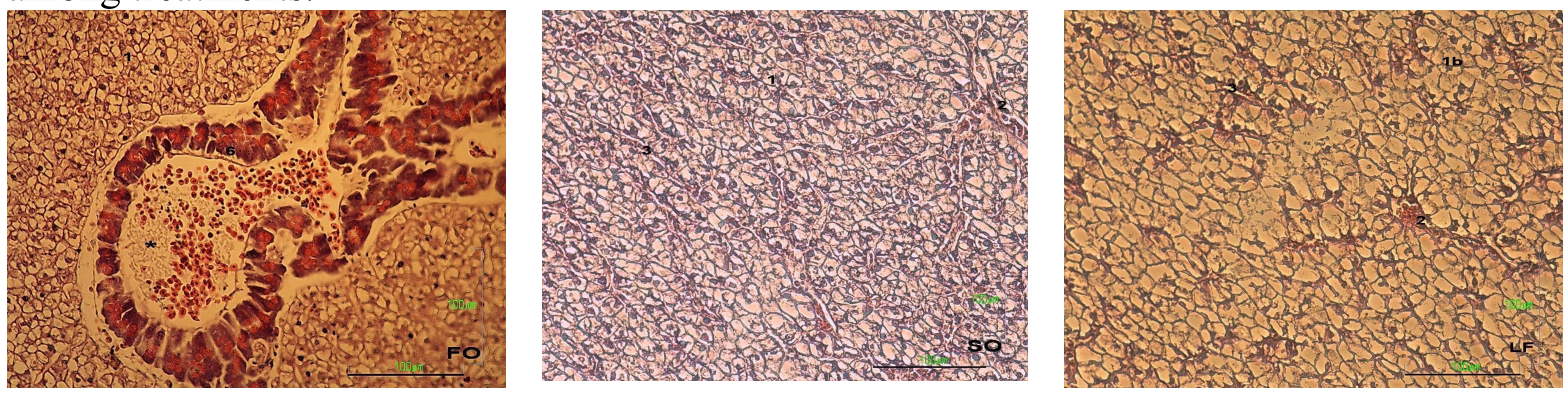

Figure 3. Photos of sharpsnout sea bream' livers fed with FO, SO and FL experimental diets.(1) hepatocytes vacuolated. (1b) hepatocytes (20x) Different superscript letters denote significant differences within row $(\mathrm{P}<0.05)$. Five replicates per treatment were analysed.

Le et al. (2009) suggested that in human nutrition the real EFA would be AA and DHA that are the precursors to pro-inflammatory and anti-inflammatory eicosanoids 
especially for premature infants. And according to Bell and Waagbø (2008) the Committee on Medical Aspects of Food Policy (COMA), recommended a daily intake of n-3 HUFA of $200 \mathrm{mg}$ /day and these values would be reached in $100 \mathrm{~g}$ of sharpsnout sea bream fillet.

The histological study reported some alteration in hepatocytes, especially in fish fed PL with a reduction of hepatocytes' number, also a degeneration of nuclei and cytoplasm. Although Caballero et al. (1999) reported hepatocyte degeneration caused by the increment of lipid content in the diet $(27 \%$ CL) associated to the high fish meal quality in gilthead seabream. Similar hepatocyte degeneration was reported in Oncorhynchus mykiss by Caballero et al. (2002) but in this case associated to high vegetal and pork lard substitution; these authors suggested the direct absorption and esterification of dietary fatty acids in muscle that contributed to obtain regular shape hepatocytes in diet containing SO, that was not the case of PL diet. They also attributed to the LA mobilisation from liver to muscle thanks to the acyltransferases, Ruyter et al. (2006) indicated that the higher lipid accumulation in liver could be due to a higher content of oleic acid (OA), in the case of fish fed PL was higher (24.78\%) in relation to the other treatments $(18.65$ and $18.03 \%)$. But this needs further investigation. Another possible reason for intra hepatocyte lipid accumulation was mention by $\mathrm{Lu}$ et al. (2008), in fish lipids from liver are transported to other tissues by different lipoproteins which contain a high content of Phospholipids (Sheridan 1988; Santulli et al. 1993).

Moreover, Benedito Palos et al. (2010) indicated that high replacement levels of fish oil and fish meal often induce lipoid liver diseases, unless the diets were well balance in plant protein and supplemented with soy lecithin, this could explain why hepatocytes of fish fed with SO diet were healthier than fish from the other treatments.

Besides Beresford and Henninger (1986) indicated, there are factors that make hepatocytes vary in the same liver and among livers of the same species; they also mentioned that intrahepatic variation is more striking in ectotherms than homeotherms and events of the life cycle, such as sexual maturation, can cause an intraspecific variation.

Nevertheless, fish fillet sensorial quality did not present statistical differences either in colorimeter parameters or by sensorial test. Similar results were commented by Martinez-Llorens et al. (2007) who commented that gilthead sea bream fed with soybean oil were preferred by panellists. Besides the atherogenicity and thrombogenicity index, so related to coronary heart diseases, were not affected by fish oil substitution and these values were as low as those reported by Valfré et al. (2003) to sea bass IT $(0.25 \%)$ and IA $(0.45 \%)$, so sharpsnout sea bream fed with SO or PL could be as healthy as fed with FO.

\section{Conclusion}

Fish oil replacement by alternative oils like soybean oil and pork lard can be consider as an alternative in sharpsnout sea bream culture. Growth and feed efficiency parameters as well as quality parameters such as atherogenicity and thrombogenicity index and triangular test did not present significant differences among treatments. But histological analysis showed that pork lard and a $100 \%$ of fish oil could affect fish liver health, although further research should be necessary to confirm these data, but it seemed that the omnivorous habits could be related with this fact. More over sharpsnout sea bream 
fatty acids in liver and fish muscle were affected by experimental diets, especially in n-3 HUFA, that are consider the most relevant for human health.

\section{Bibliography}

Almaida-Pagán PF, Hernández MD, García Garcia B, Madrid JA, De Costa J, Mendiola P (2007) Effects of total replacement of fish oil by vegetable oils on $n-3$ and n-6 polyunsaturated fatty acid desaturation and elongation in sharpsnout seabream (Diplodus puntazzo) hepatocytes and enterocytes. Aquaculture 272: 589-598.

Bell JG, Waagbø R (2008) Safe and Nutritious Aquaculture Produce: Benefits and Risks of Alternative Sustainable Aquafeeds (Chapter 6) in: Aquaculture in the Ecosystem. (Eds) Holmer et al. (NIFES) Bergen, Norway $185-225$.

Benedito-Palos L, Navarro JC, Bermejo-Nogales A, Saera-Vila A, Kaushik S, Pérez-Sánchez J (2009) The time course of fish oil wash-out follows a simple dilution model in gilthead sea bream (Sparus aurata L.) fed graded levels of vegetable oils. Aquaculture 288: 98 -105.

Benedito-Palos L, Navarro JC, Kaushik S, Pérez-Sánchez J (2010) Tissue-specidif robustness of fatty acid signatures in cultured gilhead sea bream (Sparus aurata L.) fed practical diets with a combined high replacement of fish meal and fish oil. J Anim Sci 88: $1759-1770$.

Beresford W.A., Henninger J.M (1986) A tabular Comparative Histology of the Liver (Review). Arch. Histol. Jap., Vol 49, (3), $267-281$.

Caballero MJ, López-Calero G, Socorro J, Roo FJ, Izquierdo MS, Férnández AJ (1999) Combined effect of lipid level and fish meal quality on liver histology of gilthead seabream (Sparus aurata). Aquaculture 179: $277-290$.

Caballero MJ, Obach A, Rosenlund G, Montero D, Gisvold M, Izquierdo MS (2002) Impact of different dietary lipid sources on growth, lipid digestibility, tissue fatty acid composition and histology of rainbow trout, Oncorhynchus mykiss. Aquaculture 214: $253-271$.

Das UN (2006) Essential fatty acids: biochemistry, physiology and pathology. Biotechnology Journal 1: $420-439$.

Fountoulaki E, Vasilaki A, Hurtado R, Grigorakis K, Karacostas I, Nengas L, Rigos G, Kotzaminis Y, Venou B, Alexi MN (2009) Fish oil substitution by vegetable oils in commercial diets for gilthead sea bream (Sparus aurata L.); effects on growth performance, flesh quality and fillet fatty acid profile. Recovery of fatty acids profiles by a fish oil finishing diet under fluctuation water temperatures. Aquaculture 289: 317 - 326.

Izquierdo MS, Fernández-Palacios H, Tacon AGJ (2001) Effect of broodstock nutrition on reproductive performance of fish. Aquaculture 197: $25-42$.

Lall SP (2010) The health benefits of farmed salmon: fish oil decontamination processing removes persistent organic pollutants. British Journal of Nutrition 103: $1391-1392$.

Le HD, Meisel JA, Meijer VE, Gura KM, Puder M (2009) The essentiality of arachidonic acid and docosahexaenoic acid. Prostaglandins Leukot Essent Fatty acids 81: 165 - 170.

Lu S, Zhao N, He R (2008) Effect of soybean phospholipid supplementation in formulated microdiets and live food on foregut and live histological changes of Pelteobagrus fulvidraco larvae. Aquaculture 278: 199 - 127.

Martinez-Llorens S, Tomás Vidal A, Moñino AV, Pla Torres M, Jover Cerdá M (2007) Effects of dietary soybean oil concentration on growth, nutrient utilization and muscle fatty acid composition of gilthead se bream (Sparus aurata L.).Aquac. Res 38: 76 -81.

McFaden IRB, Coombs SH, Halliday NC (1997) Histological indices of the nutritional condition of sardine, Sardina pilchardus (Walbaum) larvae off the north coast of Spain. J. Exp Mar Biol Ecol 212: 239 - 258 .

Mørkøre T, Netteberg C, Johnsson L, Pickova J (2007) Impact of dietary oil source on product quality of farmed Atlantic cod, Gadus morhua. Aquaculture 267: 236 - 247.

O'Fallon JV, Busboom JR, Nelson ML, Gaskins CT (2007) A direct method for fatty acid methyl ester synthesis. Application to wet meat tissues, oils and feedstuffs. J. Anim. Sci 85: 1511-1521.

Olsen R.E, Ringø E (1997) Lipid digestibility in fish: a review. Recent Research Development in Lipid Research 1: $199-265$.

Pajuelo JG, Lorenzo M, Domínguez-Seoane R (2008) Gonadal development and spawning cycle in the digynic hermaphrodite sharpsnout seabream Diplodus puntazzo (Sparidae) off the Canary Islands, northwest of Africa. J Appl Ichthyol 24: 68- 76.

Papadaki M, Papadopoulou M, Siggelaki I, Mylonas CC (2008) Egg and sperm production and quality of sharpsnout sea bream (Diplodus puntazzo) in captivity. Aquaculture 276: 187 - 197. 
Piedecausa MA, Mazón MK, García García B, Hernández MD (2007) Effects of total replacement of fish oil by vegetable oils in the diets of sharpsnout seabream (Diplodus puntazzo). Aquaculture 263: 211-219.

Ruyter B, Moya-Falcón C, Rosenlund G, Vegusdal A (2006) Fat content and morphology of liver and intestine of Atlantic salmon (Salmo salar): Effects of temperature and dietary soybean oil. Aquaculture 252: 441 - 452. Doi: 10.1016/j.aquaculture.2005.07014

Pickova J, Mørkøre T (2007) Alternate oils in fish feeds. Eur. J. Lipid Sci. Technol. 109: 256-263

Rodríguez- Carpena JG, Morcuende D, Estévez M (2011)... Meat Science

Salhi M, Hernández-Cruz CM, Bessonart M, Izquierdo MS, Fernandez-Palacios H (1999) Effect of different dietary polar lipid levels and different n-3 HUFA content in polar lipids on gut and liver histological structure of gilthead seabream (Sparus aurata) larvae. Aquaculture 179: 253 $-263$.

Santulli A, Modica A, Cutatolo A, D’Amelio V (1993) Lipid and apoprotein composition of lipoprotein of sea bass (Dicentrarchus labrax L.) Proceedings of World Aquaculture 93 from Discovery to Commercialization. Torremolinos, Spain. Eur Aquacult Soc (Spec. Publ.) Vol 19. 461.

Sargent J, Bell G, McEvoy LA, Tocher D, Estevez A (1999) Recent developments in the essential fatty acid nutrition of fish. Aquaculture 177, $191-199$.

Sheridan MA (1988) Lipid dynamics in fish: aspects on absorption, transportation, deposition and mobilization. Comp Biochem Physiol 90B: 679 - 690.

Snedecor G, Cochran W (1971). Statistical Methods. The Iowas State University Press. Ames. Iowa, USA $592 \mathrm{pp}$.

Tramati C, Savona B, Mazzola A (2005) A study of the pattern of digestive enzymes in Diplodus puntazzo (Cetti, 1777) (Osteichthyes,Sparidae): evidence for the definition of nutritional protocols. Aquacult Int 13: 89 - 95.

Turchini GM, Torstensen BE, Ng W-K (2009) Fish oil replacement in finfish nutrition. Rev Aquacult 1: $10-57$

Uysal K, Yerlikaya A, Aksoylar MY, Yöntem M, Ulupinar M (2006) Variations in fatty acids composition of pikeperch (Sander lucioperca) liver with respect to gonad maturation. Ecol Freshwat Fish 15: $441-445$.

Valfré F, Caprino F, Turchini GM (2003) The health Benefit of Seafood. Vet Res Commun (27 Suppl.) 1: $507-512$.

Wassef EA, Wahby MO, Sakr EM (2007) Effect of dietary vegetable oils on health and liver histology of gilthead seabream (Sparus aurata) growers. Aquaculture Research 38: 852 - 861.

Wold P-A, Hoehne-Reitan K, Cahu CL, Infante JZ, Rainuzzo J, Kjørsvik E (2009) Comparison of dietary phospholipids and neutral lipids, effects on gut, liver and pancreas histology in Atlantic cod (Gadus morha L.) larvae. Aquaculture Nutrition 15: 73 - 84.

Xue M, Luo L, Wu X, Ren Z, Gao P, Yu Y, Pearl G (2006) Effects of six alternative lipid sources on growth and tissue fatty acid composition in Japanese sea bass (Lateolabrax japonicus). Aquaculture 260: 206-214. 
CAPÍTULO 10

DISCUSIÓN GENERAL 



\section{CAPITULO 10. DISCUSION GENERAL}

De acuerdo con los resultados de la presente Tesis doctoral (Figura 10.1), se puede afirmar que es posible sustituir la harina de pescado (HP) por el turtó de girasol (TG) en ambas fases hasta un 35\% (pre-engorde y engorde), no así por el concentrado proteico de guisante (CPG), en alevines de sargo picudo. De igual forma, es posible sustituir parcialmente el aceite de pescado (AP) un 75\% durante la fase de pre-engorde y un 50\% durante la fase de engorde por aceite de soja (AS) o manteca de cerdo (MC). Estas sustituciones de harina y aceite de pescado permiten no sólo reducir los costes de producción, puesto que las materias primas alternativas están disponibles a menor coste en el mercado, sino que además permiten ofrecer animales sanos, y sin modificaciones sensoriales a nivel del consumidor, ya que, además de tener en cuenta el porcentaje de inclusión o sustitución de las materias primas alternativas, también se debe considerar el efecto que éstas tienen sobre la salud del animal y la calidad de su carne.

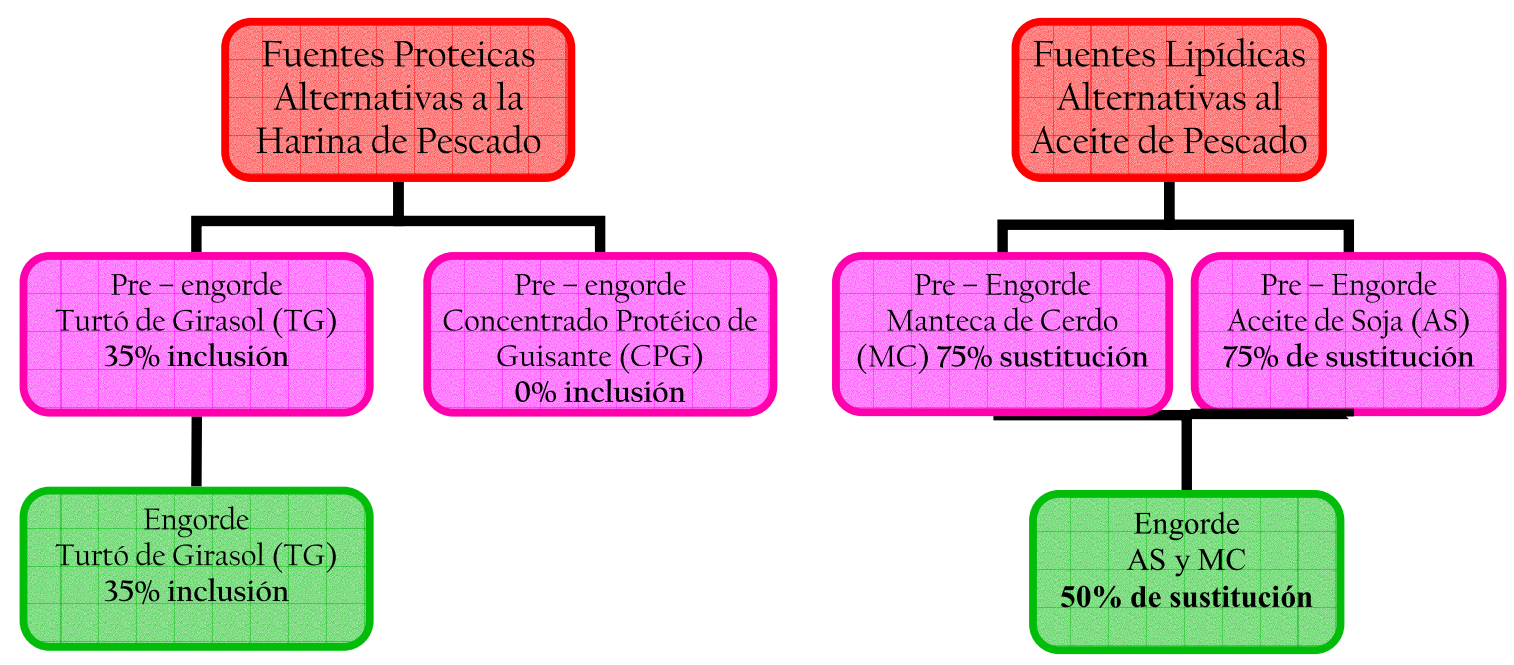

Figura 10.1. Relación de las distintas pruebas realizadas en la presente Tesis Doctoral y resultados.

TG: Turtó de girasol; CPG: Concentrado proteico de guisante; AS: Aceite de soja; MC: Manteca de cerdo.

Respecto a las pruebas realizadas con fuentes proteicas durante la fase de preengorde, los peces alimentados con TG no presentaron diferencias significativas ni en el crecimiento, ni en los parámetros nutritivos hasta con la máxima inclusión (35\%). Por ello, se probaron los mismos niveles en la fase de engorde, sin observar diferencias en el crecimiento a lo largo del experimento. Aunque en este caso, la tasa de alimentación 
disminuyó significativamente a medida que se incrementaba la inclusión, mostrando una mejor eficiencia alimentaria a mayor inclusión de TG. Por otra parte, en los sargos alimentados con el CPG, sí se encontraron diferencias estadísticas en el crecimiento, siendo éstas inversamente proporcionales al porcentaje de inclusión de la proteína vegetal, aunque la eficiencia alimenticia no se vio afectada por la inclusión del concentrado vegetal. Esta disminución gradual en el crecimiento, posiblemente, se debiese a la combinación entre la eficiencia de algunos AEE junto con la presencia de compuestos antinutricionales presentes en el CPG que no habrían sido eliminados por el tratamiento empleado para la obtención de este concentrado proteico, lo que se corrobora con las alteraciones histológicas, que se comentarán más adelante. A raíz de los resultados, no se realizaron las pruebas de engorde.

En cuanto a los experimentos de sustitución del aceite de pescado por fuentes lipídicas alternativas, no se obtuvieron diferencias significativas ni en los parámetros de crecimiento, ni en la eficiencia nutritiva durante la fase de pre-engorde hasta el $75 \%$ de sustitución del AP por AS o por MC. En la fase de engorde, sólo se probaron sustituciones de hasta un $50 \%$, por una parte visto los crecimientos del pre-engorde y por la otra, para asegurar una menor alteración en el perfil de ácidos grasos corporales del sargo en talla comercial. Tampoco se obtuvieron diferencias en el crecimiento en ninguna de las sustituciones del 50\% del AP, aunque sí hubo una disminución de la eficiencia alimenticia con la inclusión del 50\% de MC (ICA de 2,72 frente a 2,51 y 2,42 de AP y AS, respectivamente).

En todas las pruebas realizadas durante la fase de engorde, los experimentos concluyeron cuando los peces alcanzaron un peso promedio de aproximadamente 250 g, ya que éstos presentaron un estancamiento en el crecimiento debido a las siguientes causas: 1) los animales entraron en maduración sexual, lo que ocasionó una ralentización del crecimiento y 2) una disminución gradual de la temperatura lo que contribuyó a un descenso de la ingesta y por consiguiente una disminución del crecimiento.

En general, se puede afirmar que los niveles de sustitución utilizados en todas las pruebas, tanto de fuentes proteicas como lipídicas, no afectaron a la supervivencia 
del sargo, ya que ésta se mantuvo alrededor del 90\% y la mayoría de las bajas se debieron al escape de los peces de las jaulas o tanques.

\subsection{FUENTES PROTEICAS ALTERNATIVAS.}

De los escasos trabajos que se han realizado sustituyendo la harina de pescado por una fuente proteica vegetal en sargo picudo, existe uno en el que se trabajó con el turtó de soja (Hernández et al., 2007) y donde no se encontraron diferencias de crecimiento con un 60\% de inclusión de esta materia prima en alevines de sargo hasta 100 g. Este nivel de inclusión fue posible debido a que el turtó de soja posee un 45 - 50\% $\mathrm{PB}$, en comparación con el TG que tiene $32-35 \% \mathrm{~PB}$ y un alto contenido en fibra. Aunque la máxima inclusión de TG fue del 35\%, habría que valorar económicamente si es más adecuada, ya que el precio en el mercado del turtó de soja duplica al del turtó de girasol (0,29 frente a 0,13 $€ / \mathrm{Kg}(\mathrm{FAO}, 2009)$.

En el otro trabajo en el que se sustituyó la harina de pescado en piensos para alevines de sargo, se probó el concentrado proteico de alfalfa (CPA) (Chatzifotis et al., 2006), materia prima con un elevado contenido en proteína (50 - 55\%). Los resultados obtenidos por estos autores fueron poco satisfactorios, ya que únicamente consiguieron no empeorar el crecimiento con una inclusión de CPA de un 7\%, lo que atribuyeron a un alto contenido en fibra del pienso y a la presencia de sustancias anti nutricionales, tales como saponinas, taninos y fenoles (Chatzifotis et al., 2006). Algo similar ha ocurrido con el CPG en la presente tesis doctoral, ya que a pesar de ser una materia prima con un alto contenido proteico, no se consiguieron buenos resultados de crecimiento, incluso con el menor nivel de inclusión probado, posiblemente, por la presencia también de compuestos antinutricionales (taninos, lectinas y cianógenos), lo que pudo haber causado la alteración de los parámetros de crecimiento y eficiencia nutritiva. Sin embargo, hay que indicar que es una materia prima con la que se han obtenido buenos resultados en otras especies carnívoras como el salmón (Overland et al., 2009) o la dorada (Sánchez-Lozano et al., 2011).

Considerando la fase de engorde sólo se cuenta con un trabajo anterior en el que se sustituyó la harina de pescado por turtó de soja (Hernández et al., 2007), donde se encontraron diferencias significativas en el crecimiento y la eficiencia nutritiva con un 
60\% de inclusión, atribuido a la presencia de antinutrientes como el ácido fítico o los oligosacáridos que suelen reducir el crecimiento (Gatlin et al., 2007), y que pueden afectar cuando son pruebas realizadas a largo plazo. El nivel de inclusión máximo recomendado fue del $40 \%$ TS que sería similar al obtenido en los sargos alimentados hasta con un 35\% de inclusión de TG en el que sólo la tasa de alimentación disminuyó significativamente a medida que aumentaba la inclusión vegetal, sin que esto afectará el crecimiento.

La utilización de TG en otras especies en fase de engorde ha obtenido resultados similares o peores que en el caso del sargo picudo. De hecho, únicamente en el salmón (Gill et al, 2006) no fue afectado el crecimiento con una inclusión de TG de un 27\%, eso sí, con girasol decorticado, lo que disminuía el contenido de fibra de los piensos a prácticamente la mitad. En el caso de la doradas (Sánchez-Lozano et al., 2007), el nivel de TG recomendado fue del $24 \%$, ya que aunque un nivel superior no afectó al crecimiento, sí aumentó significativamente la tasa de alimentación lo cual empeoró la eficiencia alimentaria a mayor nivel de inclusión (36\%). Este detrimento en la eficiencia alimentaria es la consecuencia del elevado contenido en fibra, que como se ha comprobado, sobretodo en el caso de especies carnívoras, acelera el tránsito intestinal y por lo tanto disminuye la digestibilidad de los piensos, ya que la fibra es indigestible para estas especies e incluso para algunas especies omnívoras (Guillaume et al., 2004).

Así pues, en el empleo de materias primas vegetales, la fibra juega un rol importante en la nutrición acuícola, que en el caso del TG, a pesar de ser muy elevada (23\%), no parece haber afectado los parámetros de eficiencia nutritiva y de crecimiento, inclusive con el pienso de máxima inclusión (35\%), que tenía más de un $7 \%$ de fibra. El sargo no sólo posee enzimas proteolíticas y lipídicas sino también amilasa y celulasa (Tramati et al., 2005; Kamaci et al., 2009; Savona et al., 2011) lo que le permite aprovechar mejor el alimento con una mayor inclusión de proteína vegetal. En cambio, en el caso de CPA (Chatzifotis et al., 2006) el detrimento en el crecimiento no fue por su alto contenido en fibra, sino por los compuestos antinutricionales termoestables, que afectaron a la eficiciencia del alimento. El TG también tiene compuestos antinutricionales como los fitatos y fenoles, pero en cambio son termolábiles (Gandhi et 
al., 2008), por lo que puede que se anulen durante el proceso de cocción-extrusión, sin embargo, hay que tener en cuenta las saponinas (que son termoestables).

No se debe olvidar que gran parte del éxito de la sustitución de la harina de pescado por una fuente proteica alternativa está supeditado al perfil aminoacídico de dicha fuente, ya que la mayoría son deficientes en uno o varios AAE, especialmente en lisina y metionina, limitando su inclusión en los piensos (Francis et al., 2001; Gatlin et al., 2007). De igual forma, la suplementación con AA sintéticos ha demostrado que no es del todo eficiente, puesto que éstos se absorben antes que los AA que forman parte de la proteína de las harinas (Marcouli et al., 2004), por ello el porcentaje de inclusión de dichas fuentes debe ser cuidadosamente determinado para evitar carencias nutricionales que puedan afectar a la salud y el crecimiento del pez.

\section{AMINO ÁCIDOS Y RETENCIONES AMINOACÍDICAS}

El tipo de fuente proteica empleada en los piensos, no suele influir directamente sobre la composición aminoacídica de los peces (Wilson, 2002), no obstante, se ha visto que si un pienso no está bien equilibrada a nivel de aminoácidos esenciales (AAE), los animales suelen presentar carencias como el retardo en el crecimiento o malformaciones, por ello es necesario valorar la calidad del perfil aminoacídico. En la presente tesis, esta calidad se hizo a través del ratio entre los AAE de los piensos y los AAE corporales, para evaluar si los piensos tenían un perfil aminoacídico correcto. Antes de comentar las deficiencias encontradas en los distintos piensos para el sargo picudo, habría que aclarar que este ratio utilizado correctamente para tal fin, debe tener en cuenta los AAE digeridos, es decir, la digestibilidad de los AAE de los diferentes piensos. Como se observa en los trabajos de la tesis, la digestibilidad no se pudo llevar a cabo, aunque, como las diferencias en crecimiento sólo afectaron a los sargos alimentados con CPG (donde como se discutirá posteriormente se produce una clara deficiencia de metionina) se puede usar este ratio como índice orientativo.

La Figura 10.2 muestra el ratio aminoacídico $\left(\mathrm{RAA} \%=\left(\mathrm{AA}_{\text {muestra }}\right) /\left(\mathrm{AA}_{\text {corporal }}\right)\right.$ * 100, donde el $\mathrm{AA}_{\text {muestra }}$ representa el contenido de AA en el pienso de estudio y $\mathrm{AA}_{\text {corporal }}$ es la del pez completo (valor medio por tratamiento, ambos expresados como mg AA/g de proteína) comparando el pienso control (HP), con los piensos con la máxima 
inclusión de TG y CPG. Un RRA cercano al 100\% en todos los AA de un pienso, reflejaría un perfil adecuado y el AA con un menor RAA, sería el más limitante.

Así, podemos observar que el pienso control únicamente presentó un RAA menor en la arginina (pre-engorde y engorde). Sin embargo, con el pienso TG 35 durante la fase de pre-engorde se observa que el menor RAA se produjo en la metionina.

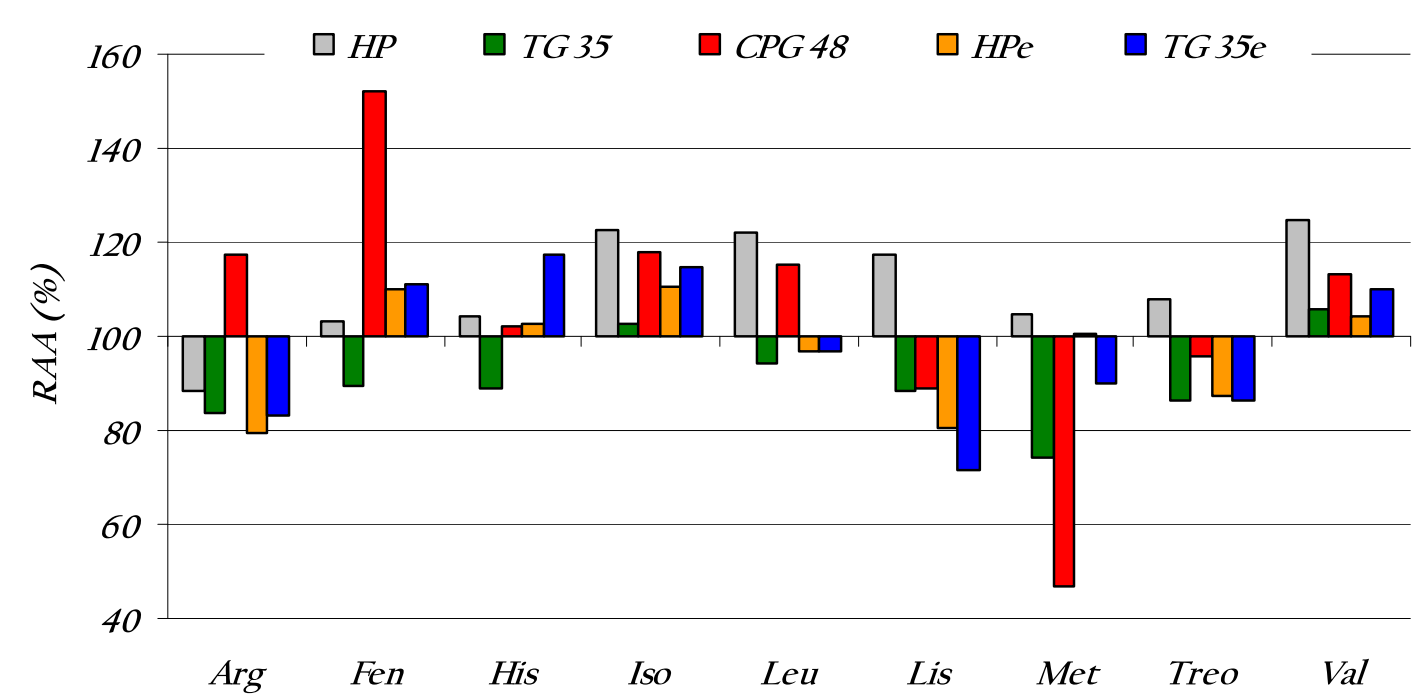

Figura 10.2 Ratio aminoacídico del pienso control y las inclusiones máximas de cada experimento realizado en la presente tesis doctoral. HP: pienso control; HPe: Pienso control engorde; TG35: 35\% de inclusión de Turtó de girasol en fase de pre-engorde; CPG 48: 48\% de inclusión de Concentrado proteico de guisante; TG 35e: 35\% de inclusión de turtó de girasol en fase de engorde. Ratio Aminoacídico (RAA $\%)=\left(\mathrm{AA}_{\text {pienso }}\right) /\left(\mathrm{AA}_{\text {pez }}\right) * 100$ (expresados como mg AA/g de proteína $)$.

De igual forma, si se compara la máxima inclusión de CPG (pienso CPG 48), se observa una menor RAA en metionina, con un ratio bastante inferior al del resto de los piensos, siendo éste uno de los AAE más limitante y responsable en la síntesis proteica (Li et al., 2007; Wilson, 2002).

En los sargos de engorde alimentados con TG, se vio que los AAE más limitantes en el pienso con mayor inclusión fueron arginina, leucina, metionina, treonina y en mayor proporción lisina, mostrando una disminución de éste de un 25\% en el pienso con relación a la composición corporal de los peces (Figura 10.2). 
La calidad del perfil aminoacídico se puede valorar también, a través del Índice de Oser (IO; Oser, 1951), índice de la calidad nutricional que se obtiene a través de la siguiente fórmula $\left(\mathrm{OI}=\left(10^{\left(1 / n^{*}(\log (\mathrm{AAR} 1)+\log (\mathrm{AAR} 2) \ldots+\log (\mathrm{AARn}))\right.}\right)\right)$. Donde AARl, AAR2,...AARn son los ratios de AAE y "n" es el número de AAE detectados. Otro valor empleado ha sido el Computo Químico (CS \%) que es el valor mínimo de los valores de RAA.

A medida que aumentaba la inclusión de fuente vegetal el IO disminuyó. El CS muestra que en la fase de pre-engorde, tanto para los peces alimentados con TG como para aquellos que comieron el CPG, el AA limitante fue la metionina, aunque en el caso de los peces que consumieron el TG esta diferencia no llegó al 25\%. Sin embargo, en aquellos que consumieron CPG el CS iba disminuyendo gradualmente a medida que se incrementaba la inclusión, llegando a mostrar un CS menor al 50\% con la máxima inclusión. En la fase de engorde, en el CS se vió que el AAE más limitante fue la lisina, mostrando una disminución gradual en su CS.

Tabla 10.1.Parámetros empleados para determinar el aminoácido limitante en los piensos.

\begin{tabular}{|c|c|c|c|c|}
\hline Tratamientos & TG 0 & TG 12 & TG 24 & TG 35 \\
\hline $\mathrm{IO}$ & 98,64 & 96,97 & 93,95 & 89,13 \\
\hline CS (\%) & 88,41 & 77,30 & 80,60 & 74,35 \\
\hline AACS & Arginina & Metionina & Metionina & Metionina \\
\hline Tratamientos & CPG 0 & CPG 16 & CPG 32 & CPG 48 \\
\hline $\mathrm{IO}$ & 98,64 & 93,73 & 90,74 & 90,28 \\
\hline CS (\%) & 88,41 & 67,86 & 50,72 & 46,72 \\
\hline AA CS & Arginina & Metionina & Metionina & Metionina \\
\hline Tratamientos & TG Oe & TG $12 \mathrm{e}$ & TG 24e & TG 35e \\
\hline $\mathrm{IO}$ & 93,34 & 92,42 & 92,60 & 91,46 \\
\hline CS (\%) & 79,45 & 75,80 & 75,31 & 71,62 \\
\hline AA CS & Arginina & Lisina & Lisina & Lisina \\
\hline
\end{tabular}

AA CS: Es el aminoácido que corresponde al computo químico.

Con estos índices se puede ver que los piensos que contenían CPG fueron los que mostraron una mayor limitación de AAE, especialmente metionina y lisina, por lo que habría sido necesaria una suplementación mayor de la que se realizó en esos piensos. En los piensos en las que se empleó el TG se tendría que valorar la inclusión de 
metionina y en menor proporción de lisina, aunque en menor proporción para obtener piensos más equilibrados para el sargo picudo.

La aplicación directa de todo ello, sería utilizar estos índices antes de la fase de alimentación, para corregir los desequilibrios en AAE, conociendo el perfil de AAE de los piensos diseñados y el de la especie objeto de estudio, bien mediante la adición de AAE sintéticos o mediante la mecla con otras fuentes proteicas.

Si se relacionan los valores obtenidos con el IO y CS (Tabla 10.1) con las eficiencias de retención (Tabla 10.2), se aprecia una relación muy directa, mostrando una mayor eficiencia de la retención el AAE más limitante. Se observa que en el caso de los sargos de pre-engorde, fue la metionina, la cual aumentó de un 22,81 en aquellos que consumieron HP, a un 31,20\% en los sargos alimentados con el 35\% TG, llegando aproximadamente a un 54\% en los alimentados con CPG 48 (Tabla 10.2), (AAE más limitante). Esto podría indicar que la suplementación con el mismo no fue la correcta, una de las principales causas del detrimento en el crecimiento. Un defecto en la inclusión de AA en el pienso produce una alta eficiencia de la retención aminoacídica (Peres \& Oliva-Teles, 2005).

Tabla 10.2 Eficiencia de retención de aminoácidos esenciales del pienso control y las máximas inclusiones del turtó de girasol (TG), fase pre-engorde (a) y engorde (b), y del concentrado proteico de guisante $(\mathrm{CPG})$

\begin{tabular}{llllllllll}
\hline & Arg & Hist & Fen & Iso & Leu & Lis & Met & Treo & Val \\
\hline HP (a) & 26,34 & 22,81 & 22,07 & 19,06 & 19,04 & 20,44 & 22,81 & 21,85 & 18,84 \\
TG 35(a) & 26,80 & 26,10 & 25,10 & 22,20 & 24,00 & 26,00 & 31,20 & 26,50 & 21,80 \\
CPG 48.7 & 21,13 & 25,04 & 16,26 & 21,16 & 21,29 & 25,85 & 53,98 & 26,06 & 22,14 \\
\hline HP (b) & 17,50 & 13,99 & 12,48 & 10,80 & 13,26 & 15,42 & 13,68 & 16,29 & 12,11 \\
TG 35(b) & 9,71 & 14,58 & 13,86 & 12,02 & 15,20 & 19,52 & 18,03 & 19,21 & 13,01 \\
\hline
\end{tabular}

A pesar de los datos obtenidos con el IO y CS, la inclusión de proteínas vegetales no influyó en la retención aminoacídica dentro de cada prueba, ni en los sargos alimentados con TG ni aquellos alimentados con CPG.

De igual forma si se comparan los valores del IO y CS con las retenciones para los sargos en fase de engorde, alimentados con TG, se puede apreciar que la mayor 
eficiencia de retención se dio en la lisina, siendo éste el AAE limitante de acuerdo con el cómputo químico obtenido (CS), mostrando un incremento en la eficiencia de retención de 15,42\% en aquellos que consumieron HP a 19,52\% en los que consumieron $35 \%$ TG. Por otra parte, si se comparan los peces alimentados con HP se aprecia que éstos presentaron una mayor retención en la arginina en comparación con la retención obtenida en los otros AAE, corroborando los valores obtenidos con IO y el CS (Tabla 10.2).

La eficiencia de retención de AA depende de un gran número de factores como la composición de los piensos, las necesidades proteicas y aminoacídicas para cada especie y para cada peso, los crecimientos obtenidos para cada uno de los piensos, las tasas de ingesta, la temperatura y las condiciones de producción además de otros factores. Se observó que los peces en fase de engorde mostraron una menor eficiencia de retención relacionado con el tamaño de los peces (inversamente relacionado con la tasa de crecimiento).

\subsection{SUSTITUCIÓN DEL ACEITE DE PESCADO}

Los experimentos con sustitución del aceite de pescado por fuentes lipídicas se realizaron con piensos que incluían un $24 \%$ de turtó de girasol como fuente proteica vegetal, ésto de acuerdo a los resultados obtenidos en los experimentos con fuentes proteicas alternativas a la harina de pescado. No se empleó la máxima inclusión (35\%) porque se vio que a nivel histológico podría afectar y por la posible interacción de la sustitución de la harina - aceite de pescado en el crecimiento.

En la Figura 10.3 se resumen los trabajos realizados en diferentes especies alimentadas con piensos en los que ha sido sustituido el aceite de pescado por fuentes lipídicas alternativas, incluyendo los experimentos de la presente Tesis Doctoral. 


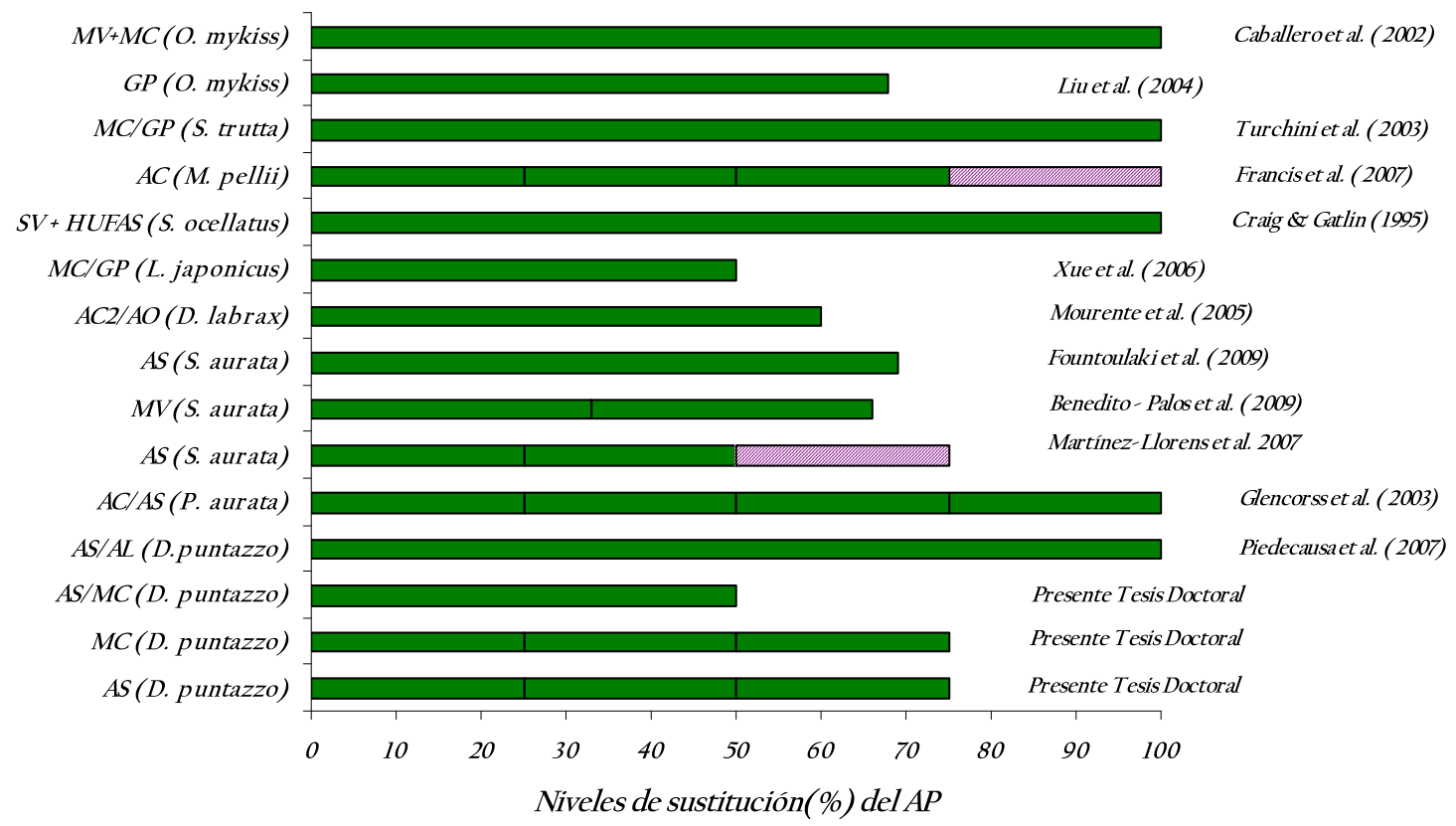

Figura 10.3. Niveles de sustitución del AP probados y máximos recomendados (color continuo) en forma porcentual en el sargo y algunas especies marinas y continentales.

AS (Ac. soja); MC (Mant. cerdo); AL (Ac. lino); MV (Mezcla vegetal); AC (Ac. canola); AC2 (Ac. colza); GP (Grasa pollo); SV (Sebo vacuno); AO (Aceite de oliva).

Como conclusiones de estos experimentos se puede extraer que cuando el AP es sustituido al 100\% por una mezcla de aceites y/o grasas, el crecimiento de los peces no se ve afectado (Caballero et al., 2002; Turchini et al., 2003 y Glencross et al., 2003). De igual forma ocurre cuando se sustituye el AP por un único aceite, pero se suplementa el pienso con HUFAS (Craig \& Gatlin, 1995). Por otra parte, cuando el aceite de pescado es sustituido por una única fuente lipídica, los resultados de crecimientos son satisfactorios hasta las máximas sustituciones probadas (60 - 65\%) (Liu et al., 2004; Mourente et al., 2005; Xue et al., 2006 y Fountoulaki et al., 2009), excepto en los experimentos de Martínez-Llorens et al. (2007), donde la máxima sustitución fue de un $48 \%$.

Sin embargo, con el sargo sí se han obtenido buenos resultados con sustituciones al 100\% del AP con un único aceite (Piedecausa et al., 2007), lo cual no ha sido comprobado en los trabajos de la presente tesis, debido a que estos piensos además de la sustitución lipídica poseían también en su composición una proporción de fuentes proteicas vegetales. 
De todas formas, el sargo picudo ha mostrado a través de los experimentos empleados en la presente tesis doctoral una mejor aceptación de las fuentes lipídicas alternativas, tanto de origen animal como vegetal, en comparación con otras especies marinas, posiblemente debido a su hábito omnívoro, ya que en su medio natural, un gran porcentaje de su alimentación está basada en una variedad de alimentos entre los que se encuentran principalmente algas, crustáceos y poríferos, fluctuando con las estaciones del año.

A pesar de que en la mayoría de las especies la sustitución del AP por fuentes lipídicas alternativas puede ser muy elevada, hay que tener en cuenta el efecto que ésta tiene en la calidad de la carne y concretamente en el perfil de AG de la misma. En la tabla 10.3 se observa el perfil de AG de las diferentes materias primas de la presente tesis, las cuales influyeron marcadamente sobre el perfil de los piensos empleados en los diferentes experimentos. En ella se puede apreciar la reducción gradual de los ácidos grasos poliinsaturados, especialmente el ácido araquidónico (ARA), ácido eicosapentaenoico (EPA), ácido docohexaenoico (DHA), inclusive hasta en más de un 70\% en las máximas sustituciones (75\% AS y 75\% MC) en comparación con el pienso control (AP). De igual forma, se observa un incremento marcado del porcentaje de ácido linoleico (LA) y ácido linolénico (LNA), especialmente en los piensos en los que se sustituyó el AP por AS.

Tabla 10.3. Perfil de ácidos grasos (AG), de las materias primas y piensos experimentales empleados en los tres experimentos, (valores expresados en \% de área*).

\begin{tabular}{lcccccccccc}
\hline & \multicolumn{3}{c}{ Materias primas } & \multicolumn{3}{c}{$\begin{array}{c}\text { Pienso } \\
\text { con AP }\end{array}$} & \multicolumn{3}{c}{ Piensos con AS } & \multicolumn{3}{c}{ Piensos con MC } \\
& \multicolumn{9}{c}{} & \multicolumn{3}{c}{ MC } & 100 & $25 \%$ & $50 \%$ & $75 \%$ & $25 \%$ & $50 \%$ & $75 \%$ \\
\hline Ac. Grasos & AP & AS & MC & & & & & & \\
\hline PA & 15,68 & 10,96 & 23,29 & 18,20 & 16,18 & 14,62 & 14,50 & 24,91 & 23,20 & 25,62 \\
SFA & 24,84 & 14,16 & 35,01 & 28,70 & 24,89 & 21,91 & 21,08 & 39,22 & 38,20 & 43,68 \\
OA & 19,29 & 25,03 & 51,66 & 15,78 & 17,05 & 19,17 & 20,32 & 18,01 & 24,35 & 27,18 \\
MUFA & 40,16 & 25,03 & 53,84 & 34,04 & 30,41 & 28,91 & 26,24 & 31,75 & 36,68 & 37,27 \\
LA & 5,74 & 54,60 & 9,25 & 6,38 & 17,87 & 30,47 & 40,63 & 7,70 & 9,11 & 9,85 \\
LNA & 2,15 & 6,15 & 1,21 & 1,49 & 2,56 & 3,63 & 4,42 & 1,32 & 1,22 & 0,91 \\
ARA & 0,94 & & 0,08 & 1,22 & 0,90 & 0,68 & 0,40 & 0,90 & 0,71 & 0,51 \\
EPA & 7,87 & & & 8,89 & 6,90 & 5,18 & 3,05 & 6,31 & 4,83 & 3,19 \\
DHA & 10,44 & & & 12,77 & 9,18 & 6,17 & 2,69 & 8,14 & 5,64 & 3,03 \\
\hline
\end{tabular}


PA: Ac. Palmítico; SFA: Ác. Grasos Saturados; OA: Ac. Oleico; MUFA: Ac. Grasos Monoinsaturados; LA: Ac. Linoleico; LNA: Ac. Linolénico; ARA: Ac. Araquidónico; EPA: Ac. Docosapentanoico; DHA: Ac. Docosahexaenoico.

*El \% de area de los ácidos grasos fue calculado como porcentaje del área de pico en relación con la sumatoria de áreas de todos los ácidos grasos de C14 a C24.

Como ya indicaron Sargent et al. (2002), el perfil de AG del pez, refleja el perfil de AG de el pienso, por ello, a pesar de que no se obtuvieron diferencias significativas en los parámetros de crecimiento, sí se observaron diferencias significativas, en la mayoría de los AG especialmente en el perfil de HUFA.

En la Tabla 10.4 se puede observar el perfil de de los principales ácidos grasos expresados en porcentaje de área del total de ácidos grasos identificados. Para interpretar la variación de un ácido graso en el músculo de un pez, al alimentarse con un pienso diferente del control, se ha calculado el índice de Turchini (UA\%) propuesto por Turchini et al. (2009).

Los filetes de los sargos picudos alimentados con piensos donde se sustituyó un 75\% de AP por AS, presentan una disminución del porcentaje de EPA, DHA y ARA, y un aumento de LA y LNA en comparación con los lomos de los peces que fueron alimentados con el pienso control (100\% AP). Con la relación de Turchini et al., (2009) se observa hasta un 35\% de reducción en el porcentaje de EPA, un 31\% en el DHA y un incremento de $286 \%$ del LA, (en el lomo de los sargos alimentados con un pienso con $75 \%$ AS en comparación con aquellos que consumieron el pienso control). Estos valores son inferiores a los obtenidos por Piedecausa et al. (2007) en sargos picudos alimentados con $100 \%$ de aceites vegetales, donde se observan diferencias del porcentaje en ARA (60\%), EPA (68\%) y DHA (65\%). Esto mismo ocurre en otras especies marinas como la dorada (Izquierdo et al., 2003; y Benedito-Palos et al., 2010), o la lubina (Izquierdo et al., 2003) donde se sustituyó el AP entre un 60 y 70\%. La única especie con un comportamiento similar al del sargo fue el salmón alimentado con 100\% AS (GrisdaleHelland et al., 2002), la reducción de DHA en el músculo es similar (35\%), debido a que esta especie, al ser anádroma, tendría la capacidad de elongación y desaturación como las especies continentales (Tocher, 2010). 
Tabla 10.4. Porcentaje de área del total de los principales ácidos grasos en el músculo de algunas especies marinas y continentales alimentadas con aceite de pescado y fuentes lipídicas alternativas e índice propuesto por Turchini et al. (2009).

\begin{tabular}{|c|c|c|c|c|c|c|c|c|}
\hline Especie & $\begin{array}{c}\text { Fuente } \\
\text { Lip. }\end{array}$ & $\%$ Sust. & LA & LNA & ARA & EPA & DHA & Autores \\
\hline & $\mathrm{AP}$ & $0 \%$ & 7,09 & 1,01 & 1,59 & 7,63 & 13,79 & Presente tesis \\
\hline Diplodus & AS & $75 \%$ & 27,39 & 2,52 & 1,16 & 4,90 & 9,52 & doctoral \\
\hline puntazzo & \multicolumn{2}{|c|}{$U A \%$} & 286,47 & 149,86 & $-26,73$ & $-35,81$ & $-30,95$ & \\
\hline \multirow{3}{*}{$\begin{array}{l}\text { Diplodus } \\
\text { puntazzo }\end{array}$} & $\mathrm{AP}$ & $0 \%$ & 7,09 & 1,01 & 1,59 & 7,63 & 13,79 & Presente tesis \\
\hline & MC & $75 \%$ & 8,94 & 0,74 & 1,57 & 6,11 & 10,25 & doctoral \\
\hline & \multicolumn{2}{|c|}{$U A \%$} & 26,12 & $-26,62$ & $-1,42$ & $-19,86$ & $-25,65$ & \\
\hline \multirow{3}{*}{$\begin{array}{l}\text { Diplodus } \\
\text { puntazzo }\end{array}$} & $\mathrm{AP}$ & $0 \%$ & 5,40 & 6,90 & 0,50 & 7,00 & 11,90 & \\
\hline & AS & $100 \%$ & 42,10 & 8,30 & 0,20 & 2,20 & 4,10 & Piedecausa et al. \\
\hline & \multicolumn{2}{|c|}{$U A \%$} & 679,63 & 20,29 & $-60,00$ & $-68,57$ & $-65,55$ & (2007) \\
\hline \multirow{5}{*}{ Sparus aurata } & $\mathrm{AP}$ & $0 \%$ & 9,33 & 0,76 & 0,63 & 9,72 & 6,16 & Benedito-Palos et al. \\
\hline & VO & $66 \%$ & 16,32 & 16,77 & 0,24 & 3,89 & 2,91 & $(2010)$ \\
\hline & \multicolumn{2}{|c|}{$U A \%$} & 74,92 & 2106,58 & $-61,90$ & $-59,98$ & $-52,76$ & \\
\hline & AP & $0 \%$ & 6,5 & 1,69 & 0,77 & 11,02 & 12,96 & \\
\hline & AS & $60 \%$ & 24,21 & 3,21 & 0,43 & 6,07 & 7,91 & \\
\hline \multirow[t]{2}{*}{ Sparus aurata } & \multicolumn{2}{|c|}{$U A \%$} & 272,46 & 89,94 & $-44,16$ & $-44,92$ & $-38,97$ & Izquierdo et al. (2003) \\
\hline & $\mathrm{AP}$ & $0 \%$ & 9,00 & 1,30 & 1,20 & 8,50 & 22,00 & \\
\hline \multirow{4}{*}{$\begin{array}{l}\text { Lateolabrax } \\
\text { japonicus } \\
\text { (Lubina } \\
\text { japonesa) }\end{array}$} & MC & $50 \%$ & 13,10 & 1,30 & 1,30 & 6,30 & 17,50 & \\
\hline & \multicolumn{2}{|c|}{$U A \%$} & 45,55 & 0,00 & 8,33 & $-25,88$ & $-20,45$ & \\
\hline & AS & $50 \%$ & 21,30 & 2,10 & 0,90 & 6,50 & 16,90 & \\
\hline & \multicolumn{2}{|c|}{$U A \%$} & 136,67 & 61,54 & -25 & $-23,53$ & $-23,18$ & Xue et al. (2006) \\
\hline \multirow[b]{3}{*}{ Salmo trutta } & AP & $0 \%$ & 6,22 & 1,29 & 0,79 & 4,96 & 19,04 & \\
\hline & MC & $100 \%$ & 9,49 & 1,02 & 0,62 & 2,90 & 13,52 & \\
\hline & \multicolumn{2}{|c|}{$U A \%$} & 52,57 & $-20,93$ & $-21,52$ & $-41,53$ & $-28,99$ & Turchini et al. (2003) \\
\hline \multirow[b]{3}{*}{ Salmo salar } & $\mathrm{AP}$ & $0 \%$ & 4,60 & 0,80 & 0,20 & 4,80 & 9,90 & \\
\hline & AS & $100 \%$ & 28,50 & 2,90 & 0,50 & 1,80 & 6,40 & Grisdale-Helland et \\
\hline & \multicolumn{2}{|c|}{$U A \%$} & 519,56 & 262,5 & 150 & $-62,5$ & $-35,35$ & al. (2002) \\
\hline \multirow{3}{*}{$\begin{array}{l}\text { Dicentrarchus } \\
\text { labrax }\end{array}$} & $\mathrm{AP}$ & $0 \%$ & 4,73 & 0,85 & 0,52 & 10,61 & 11,41 & \\
\hline & AS & $60 \%$ & 16,91 & 2,52 & 0,74 & 7,37 & 7,33 & \\
\hline & \multicolumn{2}{|c|}{$U A \%$} & 257,51 & 196,47 & 42,31 & $-30,54$ & $-35,76$ & Izquierdo et al. (2003) \\
\hline \multirow{5}{*}{$\begin{array}{l}\text { Monopterus } \\
\text { albus (anguila } \\
\text { del fango) }\end{array}$} & AP & $0 \%$ & 12,11 & 1,75 & 4,99 & 1,87 & 7,36 & \\
\hline & MC & $100 \%$ & 6,38 & 0,97 & 3,03 & 0,49 & 1,46 & \\
\hline & \multicolumn{2}{|c|}{$U A \%$} & $-47,32$ & $-44,57$ & $-39,25$ & $-73,80$ & $-80,16$ & \\
\hline & AS & $100 \%$ & 13,57 & 1,94 & 3,42 & 0,51 & 2,26 & \\
\hline & \multicolumn{2}{|c|}{$U A \%$} & 12,06 & 10,86 & $-31,43$ & $-72,73$ & $-69,29$ & Zhou et al. (2010) \\
\hline
\end{tabular}

AP: Ac. Pescado; AS: Ac. Soja; AV: Ac. Vegetales; MC: Manteca de cerdo. SV: Sebo vacuno.

LA: Ac. Linoleico; LNA: Ac. Linolénico; ARA: Ac. Araquidónico; EPA: Ac. Docosapentanoico; DHA: Ac. Docosahexaenoico.

UA $\%=(\%$ AG pez alimentado con aceite de sustitución - \% AG pez alimentado con AP) * (\%AG pez alimentado con AP) ${ }^{-1} * 100$ (Turchini et al., 2009).

Por lo que se puede observar las diferencias obtenidas en el sargo y en especies marinas, el empleo de la MC ha presentado menores disminuciones en el contenido de EPA, ARA y DHA en relación a los peces que consumieron fuentes lipídicas vegetales. Existen varias razones por las cuales la disminución en el porcentaje de estos AGE sea menor en los peces alimentados con fuentes lipídicas animales:

1. Los subproductos animales, como las grasas, proveen una cantidad adecuada de ácidos grasos mono y poli-insaturados que promueven la digestibilidad de los SFA (que se emplean como base energética) y contienen niveles adecuados de 
AGE para completar las necesidades de los animales (Bureau, 2007), los cuales por lo tanto tienen un mayor aprovechamiento.

2. Por otra parte, se ha visto que los piensos donde se emplean grasas de animales terrestres que contienen cantidades significativas de HUFA, provenientes de HP o AP, han mostrado un mejor crecimiento, debido a que éstas carecen de cantidades excesivas de LA, que de acuerdo con Turchini et al. (2009) es el AG más perjudicial desde el punto de vista nutricional y sensorial. Los piensos que incluyen grasa animal tienen un menor contenido de LA en relación al LNA. De acuerdo con Glencross (2009), existe una inhibición competitiva entre el LA y el LNA por $\Delta^{6}$ desaturasa, que es una de las enzimas encargadas de la bioconversión del LA en ARA o del LNA en EPA y DHA, favoreciendo a la bioconversión de éstos últimos AGE (Fig. 10.4).
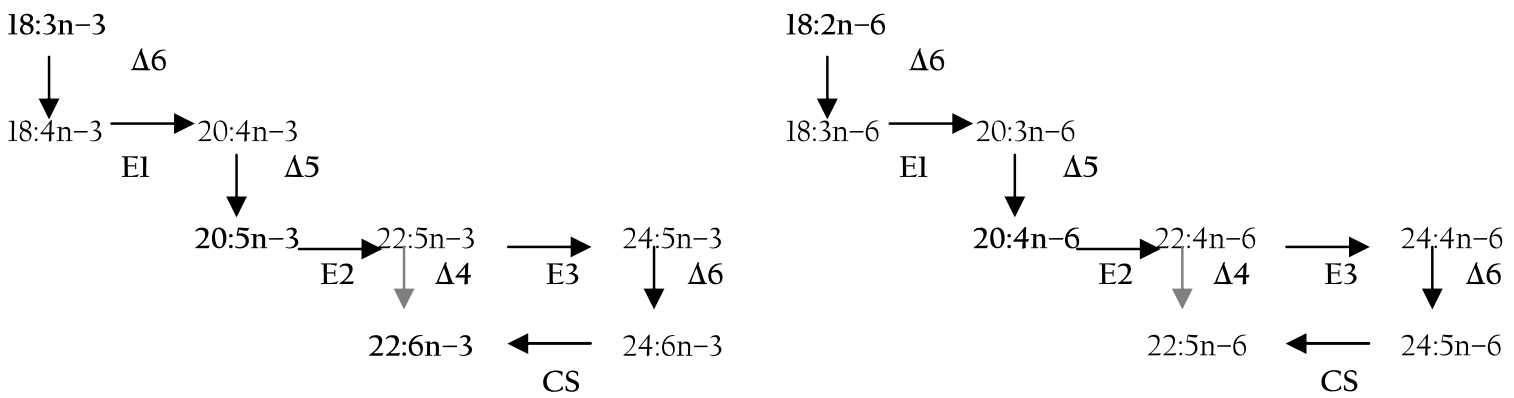

Figura 10.4. Rutas de la elongación y desaturación del Cl8 para producir ácidos grasos omega-3 y omega-6 en los hepatocitos de los peces. La ruta en gris representa el paso aún no confirmado. Cada AGE se encuentra en negritas. Reacciones mediadas por enzimas desaturasas de los AG en el microsoma $\Delta 6$; $\Delta 5$ y $\Delta 4$; reacciones mediadas por las elongasas del microsoma El; E2 y E3; CS cadena acortadora del peroxisoma del AG (Glencross, 2009).

3. Otra causa sería la presencia del ácido estearidónico ( $\mathrm{Cl}$ 18:4n3) que pueden contener algunas fuentes lipídicas animales y algunas vegetales, que es conocido por ser un precursor dentro de la ruta biosintética del EPA y DHA. Se han realizado algunas pruebas para evaluar los efectos de este AG sobre la capacidad biosintética del EPA y DHA. Así, en la sustitución del 50\% de AP por aceite de Echium, con alto contenido en ácido estearidónico, no se redujo el contenido en DHA y ARA de los lomos de doradas, aunque el contenido en EPA sí fue menor (Díaz-López et al., 2009). 
La figura 10.5, muestra la relación de Turchini (UA\%), para los ácidos grasos más valorados en nutrición acuícola, de los sargos alimentados con un pienso comercial (Rueda et al., 2001) y los alimentados con los piensos 50\% AS y 50\% MC de la presente tesis doctoral, respecto a los sargos salvajes (Rueda et al., 2001).
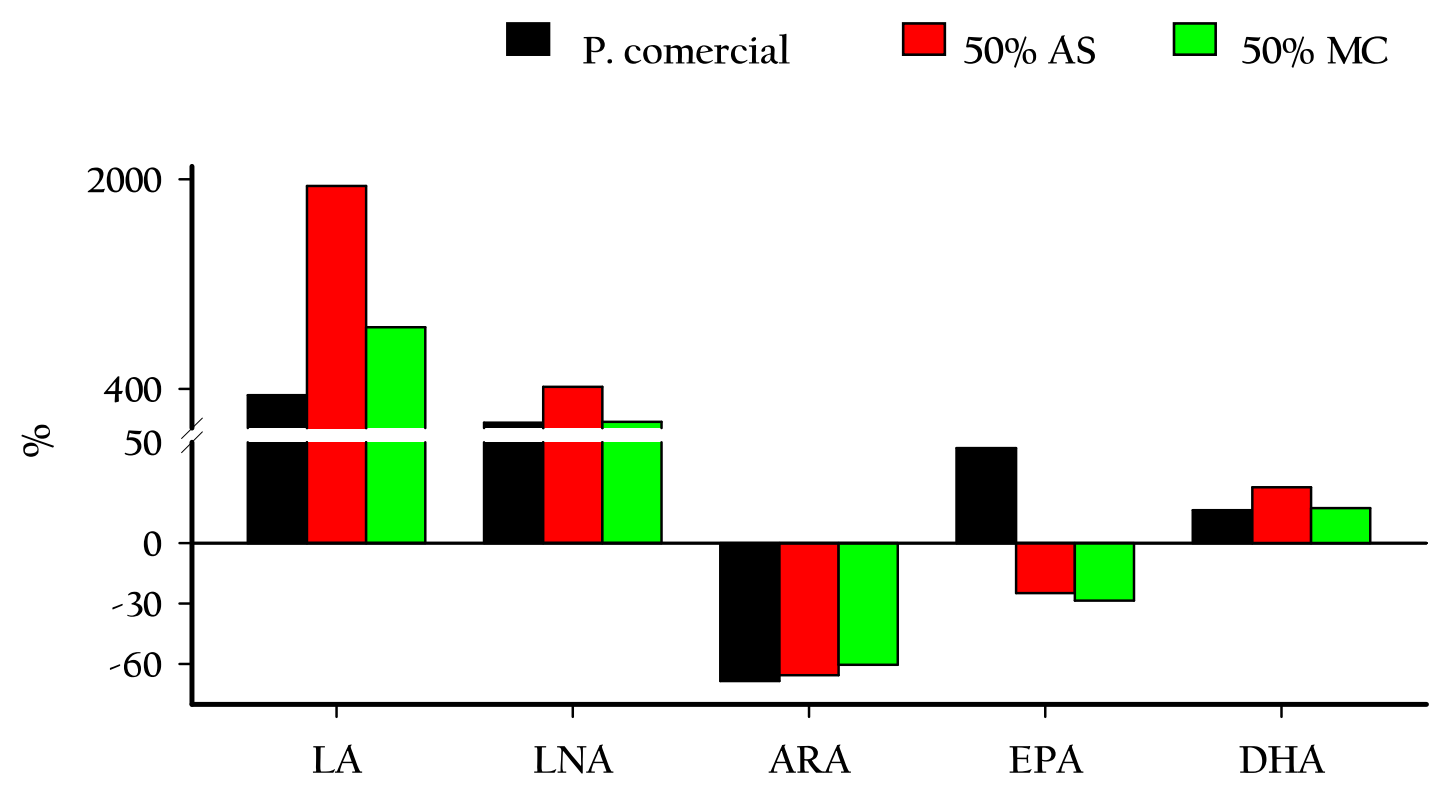

Figura 10.5 Valores obtenidos al emplear la fórmula propuesta por Turchini et al. (2009) (\% = \% AG pez alimentado con aceite de sustitución - \% AG pez salvaje) * (\%AG pez salvaje (Rueda et al., 2001) $)^{-1}$ * 100)) de sargos alimentados con piensos comerciales (Rueda et al., 2001) y de los sargos alimentados con el 50\% de AS y MC (Presente tesis doctoral).

En esta figura se observa que los porcentajes de LA y LNA aumentan en los tres casos, respecto a los peces salvajes, mientras que el ARA disminuyó. Como era de esperar, el porcentaje de LA en los peces que consumieron el pienso con el 50\% AS fue el más alto. Los sargos alimentados con el pienso comercial aumentaron su contenido en EPA pero no los alimentados con los piensos con 50\% AS y MC, que disminuyó respecto a los peces salvajes. En el caso del DHA, mejoró en los tres casos.

En resumen, podríamos decir que las altas sustituciones de aceite de pescado por aceites vegetales o grasas animales no perjudican el crecimiento del sargo en fase de pre-engorde o en fase de engorde. Además al ver el grado de modificación de la fuente lipídica del pienso en el perfil de ácidos grasos de los tejidos del sargo, se corroboran los estudios anteriores en otras especies (Caballero et al., 2002; Grisdale-Helland et al., 2002; Turchini et al., 2003; Mourente et al., 2005; Xue et al., 2006; Martínez-Llorens et al., 
2007; Zhou et al., 2010 y Wang et al., 2011) en los que se apunta la influencia del pérfil de ácidos grasos del pienso en el tejido del animal. Y por último, y a pesar de estas modificaciones en el pez como consecuencia de la alimentación, es importante el hecho de que estas diferencias en el perfil de ácidos grasos son menores cuando los sargos son alimentados con grasas animales (pre-engorde), en este caso manteca de cerdo, que con aceites vegetales (aceite de soja). La implicación directa de la relación de los ácidos grasos corporales en la calidad de la carne del pez se discute a continuación al estudiar la calidad nutricional.

\subsection{CALIDAD NUTRICIONAL DEL FILETE DEL SARGO}

La sustitución lipídica no afectó la calidad organoléptica de los sargos alimentados con 50\% AS y MC, en comparación con los peces alimentados con AP. En cuanto a las características más sobresalientes comentadas por los panelitas, resaltan que los peces alimentados con 50\% MC, presentaron un buen sabor y textura suave, y que para los sargos alimentados con 50\% AS, sus filetes eran secos, aunque de textura suave. En resumen, la percepción de los panelistas fue buena para los filetes de los peces alimentados con el 50\% de AS y MC. Igualmente, en dorada no se han observado diferencias organolépticas en peces alimentados con niveles de sustitución del aceite de pescado similares, aunque sí se encontraron cuando éstas sustituciones eran superiores (Izquierdo et al., 2005).

Sin embargo, hay estudios que afirman la preferencia por parte de los panelistas de la dorada alimentada con piensos con el 100\% de aceite de pescado como única fuente proteica (Izquierdo et al., 2003, Martínez-Llorens et al., 2007). Estas diferencias en la percepción sensorial de los panelistas dependen de varios factores, como el porcentaje de grasa muscular de los peces. Las diferencias sensoriales percibidas pueden ser de textura (Martínez-Llorens et al., 2007) o de sabor.

De acuerdo con Ruxton et al. (2004), el consumo de pescado suele incrementar el contenido de lipoproteínas de alta densidad (HDL) y disminuir el contenido de lipoproteína de baja densidad, (LDL), estas últimas asociadas a un aumento del colesterol causante de enfermedades cardiacas, lo cual se suele valorar de acuerdo a los índices de aterogenicidad (IA) y trombogenicidad (IT) puesto que estos son parámetros 
que permiten determinar que productos previenen procesos inflamatorios, trombogénicos, vaso activos, arritmogénicos y carcinogénicos (Dubnov-Raz \& Berry, 2008), siendo mejor valorado, cuánto más bajos sean estos índices en los alimentos consumidos.

El índice aterogénico es un indicador que valora la contribución de las grasas de un alimento a la generación de placas de ateroma (depósitos de lípidos) en las arterias. El índice de trombogenicidad nos da una idea del contenido equilibrado de los ácidos grasos del alimento y mide la capacidad potencial de un alimento para producir trombosis o embolias. Este índice depende fundamentalmente del contenido en PUFAS n3. Para que la ingesta de los ácidos grasos n6 y n3 sean cardiosaludables deben estar presentes en el alimento de forma equilibrada. Así la relación entre ambos, expresada como un cociente no debería exceder de 5 . Pero este valor en los alimentos occidentales actuales suele hallarse en el intervalo comprendido entre 10 y 30 , muy por encima de los valores recomendados, como se observa en los valores proporcionados por algunos autores en la Tabla 10.5 para los lomos de algunas especies terrestres a diferencia de las acuáticas.

Tabla 10.5. Índice de Aterogenicidad (IA), Índice de Trombogenicidad (IT) y la relación n6/n3 como indicativos de la calidad de la carne desde el punto de vista de salud de algunas animales marinos y terrestres más consumidos.

\begin{tabular}{lccccccccc}
\hline Índices & Lubina $^{1}$ & Anchoa $^{1}$ & Trucha & Anguila & Conejo $^{2}$ & Cerdo $^{3}$ & Cordero $^{4}$ & Pollo $^{5}$ & Ternera $^{6}$ \\
\hline IA & 0,45 & 1,35 & 0,57 & 0,94 & 0,62 & 0,52 & 0,90 & 0,58 & 0,84 \\
IT & 0,25 & 0,45 & 0,37 & 0,32 & 0,87 & 1,23 & 1,00 & 0,56 & 1,87 \\
n6/n3 & 0,58 & 0,10 & 0,36 & 0,68 & 4,98 & 10,32 & 2,50 & 8,57 & 6,06 \\
\hline
\end{tabular}

1 (Valfré et al., 2003); 2 (Volek \& Marounek, 2011); 3 (Razmaité et al., 2011); 4 (Vacca et al., 2008); 5 (Laudadio \& Tufarelli, 2010); 6 (Mele et al., 2008).

Para determinar la calidad desde el punto de vista de salud humana de los filetes de los sargos alimentados con las diferentes fuentes lipídicas, alternativas se empleó el Índice de Aterogenicidad (IA), el Índice de Trombogenicidad (IT) y la relación n6/n3 (Tabla 10.6). 
Tabla 10.6. Índices calculados de la aterogenicidad y trombogenicidad obtenidos en los experimentos de la presente tesis doctoral.

\begin{tabular}{|c|c|c|c|c|c|c|c|c|c|c|c|}
\hline & \multicolumn{4}{|c|}{ Sustitución Aceite de Soja } & \multicolumn{4}{|c|}{ Sustitución Manteca cerdo } & \multicolumn{3}{|c|}{$50 \%$ de sustitución } \\
\hline & $0 \%$ & $25 \%$ & $50 \%$ & $75 \%$ & $0 \%$ & $25 \%$ & $50 \%$ & $75 \%$ & AP & AS & MC \\
\hline IA & $0,25^{\mathrm{a}}$ & $0,22^{b}$ & $0,21^{b}$ & $0,17^{\mathrm{c}}$ & 0,25 & 0,27 & 0,25 & 0,24 & 0,40 & 0,36 & 0,40 \\
\hline IT & 0,25 & 0,25 & 0,26 & 0,25 & $0,25^{\mathrm{a}}$ & $0,30^{\mathrm{a}}$ & $0,31^{\mathrm{a}}$ & $0,38^{\mathrm{b}}$ & 0,24 & 0,28 & 0,32 \\
\hline n6/n3 & $0,36^{\mathrm{d}}$ & $0,67^{\mathrm{c}}$ & $1,05^{\mathrm{b}}$ & $1,61^{a}$ & $0,36^{\mathrm{b}}$ & $0,41^{\mathrm{b}}$ & $0,46^{\mathrm{b}}$ & $0,64^{a}$ & $0,49^{\mathrm{b}}$ & $1,23^{\mathrm{a}}$ & $0,69^{\mathrm{b}}$ \\
\hline $\begin{array}{l}\text { Índice } \\
{ }^{*}(\mathrm{MU} F \\
\text { Îndice } \\
3 \text { )+(n-3 } \\
\text { (Dond }\end{array}$ & $\begin{array}{l}\text { de atero } \\
\text { A-18:1)] } \\
\text { le tromb } \\
\text { n-6)] }\end{array}$ & nicic & IT) & (14:0 & & & & & $n-6+n-$ & $\mathrm{e}^{*}(\mathrm{~N}$ & $\begin{array}{l}\text { A) }+f \\
n * n-\end{array}$ \\
\hline
\end{tabular}

En ella se puede observar que a medida que aumenta el nivel de AS, el IA y la relación n6/n3 empeora significativamente, pero no en el caso del IT. Por otra parte, los sargos que consumieron la MC obtuvieron diferencias estadísticas en el IT, siendo mayor en los sargos que consumieron el pienso con un $75 \% \mathrm{MC}$, al igual que la relación n6/n3 que fue mayor para este mismo grupo de peces, ya que las grasas de animales terrestres son ricas en HUFAS de la serie n6. La aplicación directa a la salud humana es que favorecen el desarrollo de trombos por la presencia de ARA y de los eicosanoides derivados de él, como el tromboxano $\left(\mathrm{TXA}_{2}\right)$. Por el contrario, en alimentos ricos en HUFAS de la serie n3, tienen un IT bajo, ya que estos HUFA (especialmente el EPA) producen eicosanoides de baja capacidad proagregante $\left(\mathrm{TXA}_{3}\right)$.

Por otra parte, en los sargos de engorde no hubieron diferencias significativas ni en IA ni en IT, pero sí en la relación n6/n3, siendo los peces que consumieron el pienso con el 50\% AS los que presentaron la relación más alta (Tabla 10.6).

Si todos estos valores se comparan con los datos obtenidos en el sargo salvaje y de crianza (IA, 0,5l e IT 0,24 y IA, 0,53 e IT, 0,35) (Rueda et al., 2001); pargo salvaje y de crianza (AI, 0,4 e IT, 0,2 y IA, 0,5 e IT 0,2) (Rueda et al., 1997); dorada (IA, 0,3 e IT, 0,2) (Grigorakis, 2007) o lubina, (Tabla 10.5) (Valfré et al., 2003), estos valores no difieren. Si se comparan con los valores para trucha, anchoa y anguila, (Valfré et al., 2003), fueron superiores a los obtenidos para los sargos tanto en fase de engorde como de preengorde de la presente tesis doctoral. Si se relaciona estos valores recomendables para personas adultas que no hayan sufrido enfermedad coronaría isquémica que serían para 
el IA, 0,93 y para el IT, 1,28 (Fehily et al., 1994), indicaría que los filetes del sargo picudo, tendrían una menor incidencia en incrementar las probabilidades de sufrir una trombosis o arterioesclerosis.

Comparando los valores obtenidos en la presente tesis doctoral de los sargos alimentados con AS y MC, éstos son muy inferiores a las especies terrestres como el conejo (Volek \& Marounek, 2011), cerdo (Ramaite et al., 2011), cordero (Vacca et al., 2008), pollo (Laudadio \& Tufarelli, 2010) ternera (Mela et al., 2008) tanto en el IA, como el IT (Tabla 10.5).

Por otra parte, la relación n6/n3 que también es un indicativo de un alimento cardio saludable fue muy inferior en los sargos alimentados con AS y MC (Tabla 10.6) en comparación con algunas especies terrestres, no así marinas, las cuales presentan valores inferiores o iguales a los obtenidos en la presente tesis (Tabla 10.5).

Todos los parámetros anteriormente comentados indican que tanto la calidad nutricional, como de salud humana (basados en IA, IT y n3/n6), así como la valoración de las catas dadas por la prueba triangular realizada, muestran que los filetes del sargo picudo alimentado con un 50\% de AS y un 50\% de MC son igual de nutritivos, saludables como organolépticamente similares a los del 100\% AP.

\subsection{ALTERACIONES HISTOLÓGICAS DEBIDAS A LA UTILIZACION DE FUENTES PROTEICAS Y LIPIDICAS ALTERNATIVAS EN EL SARGO PICUDO}

Los lípidos de el pienso afectan a una variedad de funciones inmunológicas en los peces, como también pueden ocasionar el enranciamiento de los piensos debido a la presencia de una gran cantidad de PUFAS, que reaccionarían con las proteínas, vitaminas y otros componentes de el pienso, limitando su valor nutricional (Gatlin, 2002). Entre las alteraciones hepáticas más frecuentes está la esteatosis, la cual se presentó en los sargos en la fase de engorde. Esta alteración se suele dar como consecuencia de varios factores: 1) la excesiva o poco equilibrada ingesta lipídica del alimento, la cual satura la capacidad fisiológica del hígado para utilizarla, produciendo una acumulación de lípidos en forma de gotas (triglicéridos) (Spisni et al., 1998). 2) otra causa para esta anomalía, podría ser el empleo conjunto de HP de alta calidad con un 
alto contenido de AP (27\%), como citan Caballero et al. (1999) en doradas juveniles. La causa general de la esteatosis podría ser una combinación de estos factores lo que podría haber causado en los sargos picudos en fase de engorde alimentados con el $100 \%$ AP y $50 \%$ MC la presencia de esta anomalía.

Las condiciones de producción, como la cría en tanques, jaulas, el número de peces por área, etc., también pueden ser uno de los factores causantes de una gran acumulación de gotas lipídicas en los hepatocitos de la lubina (Figuereido-Silva et al., 2005). Otra causa podría ser la característica intrínseca de las especies marinas, como los espáridos, para acumular el exceso de energía a nivel del hígado y vísceras (Glencross, 2009).

Estos cambios histológicos observados en el sargo picudo en fase de engorde podrían también deberse más a un cambio morfológico temporal puesto que éstos se encontraban en la etapa de maduración sexual, coincidiendo con Barni et al. (1984) y Bruslé \&\& Gonzales i Anadon (1996), quienes indican que la maduración sexual es responsable de los cambios morfológicos en los hepatocitos.

En síntesis varios son los factores atribuibles a esta alteración hepática, no obstante, cabe destacar que ésta (cuando es debida al pienso) es reversible con una nueva alimentación adecuada, como indican Caballero et al. (2004).

Por otra parte la "enteritis a nivel digestivo", se la identifica comúnmente por el acortamiento de las vellosidades intestinales y un engrosamiento de la lamina propria, una hipertrofia e hiperplasia de las células caliciformes, disminución de las vacuolas y la infiltración de granulocitos, preferentemente en la parte distal del intestino (Baeverfjord \& Krogdahl, 1996). La enteritis puede ser causada por la presencia de inhibidores como la tripsina, quimiotripsina, elastasa y carboxipeptidasas presentes en algunas materias primas como el turtó de soja (Krogdahl et al., 2003; Urán et al., 2008), y en menor concentración en la harina de guisante y el CPG (Penn et al., 2011). Igualmente, la presencia de lectinas y saponinas, que se encuentran en semillas de leguminosas y en la soja produciría enteritis (Krogdahl et al., 2003), reduciendo de esta manera la superficie de absorción de los nutrientes. 
En el caso del sargo picudo, el CPG fue el que causó algunas alteraciones tales como la elongación de las vellosidades, posiblemente para mejorar la absorción de los nutrientes, probablemente debido a un efecto sinergético, debido tal vez a la influencia de las lectinas que pudieron irritar la membrana del intestino, produciendo una excesiva secreción de mucus y como consecuencia el aumento de células caliciformes en la parte distal (Krogdahl et al., 2010), considerada la porción de mayor absorción, que impidieron la capacidad enzimática y de absorción de la pared del intestino posterior. La presencia de las saponinas podría haber causado una depresión en la actividad enzimática de la mucosa como se observa en la parte anterior y media del intestino de los sargos alimentados con CPG, lo que a la vez, también habría incidido en la disminución del crecimiento, al aumentar la inclusión. Estas alteraciones no se observaron en los sargos alimentados con TG, al igual que en el lenguado (Bonaldo et al., 2006) alimentado con TS o la trucha arco iris (Escaffre et al., 2007) alimentada con CPS. No es el caso de la dorada (Bonaldo et al., 2008), o la carpa (Urán et al., 2008), alimentadas con TS, que sí presentaron alteraciones en el intestino, o el bacalao del atlántico que presentó una serie de anomalías histológicas debido a la sustitución total de HP por fuentes proteicas vegetales (Olsen et al., 2007). De igual forma, una inclusión del 35\% de CPG produjo enteropatía en el salmón (Penn et al., 2011), posiblemente atribuida a la presencia de la saponina, la cual podría haberse incrementado en el CPG, debido al proceso de obtención del concentrado proteico (mediante un clasificador de aire).

Las alteraciones producidas en el intestino de los sargos picudos alimentados con CPG no causaron necrosis, aunque sí una hiperplasia de las vellosidades, lo que podría haber inducido a una reducción en el crecimiento final.

Caballero et al. (2002), encontraron que con una mezcla que incluía MC y aceites vegetales se producía enteritis en la trucha arco iris. De igual forma se ha visto que los aceites vegetales como la soja o la colza han producido algunas alteraciones como la presencia de gotas lipídicas en las vellosidades intestinales en la dorada (Caballero et al., 2003) o en la trucha (Olsen et al., 2003), datos que no se han podido corroborar en esta tesis ya que sólo se realizó la histología del hígado en los peces en 
fase de pre-engorde, alimentados con AS y MC y del hígado y gónadas en los sargos en fase de engorde.

Las observaciones histológicas realizadas en las gónadas de los sargos alimentados con $100 \%$ AP y 50\% AS y MC, muestran que estos piensos no afectaron la maduración de los oocitos y espermas al final de los experimentos, aunque no indican la viabilidad de los mismos.

\subsection{BIBLIOGRAFÍA}

Barni, S., Bernocchi, G., Gerzeli, G. (1984) Morphohistochemical changes in hepatocytes during the life cycle of the European eel. Tissue and Cell, 17: 97 - 109.

Baeverfjord, G., Krogdahl, A. (1996) Development and regression of soybean meal induced enteritis in Atlantic salmon, Salmo salar L., distal intestine: a comparison with the intestines of fasted fish. Journal of Fish Diseases, 19: 375 - 387.

Benedito-Palos, L., Navarro, J.C., Bermejo-Nogales, A., Saera-Vila, A., Kaushik, S., Pérez-Sánchez, J. (2009) The time course of fish oil wash - out follows a simple dilution model in gilthead sea bream (Sparus aurata L.) fed graded levels of vegetable oils. Aquaculture, 288: 98 - 105.

Benedito-Palos, L., Navarro, J.C., Kaushik, s., Pérez-Sánchez, J. (2010) Tissue-specific robustness of fatty acid signatures in cultured gilthead sea bream (Sparus aurata L.) fed practical diets with a combined high replacement of fish meal and fish oil. Journal of Animal Science, 88: 1759 - 1770.

Bonaldo, A., Roem, A.J., Pecchini, A., Grilli, E., Gatta, P.P. (2006) Influence of dietary soybean meal levels on growth, feed utilization and gut histology of Egyptian sole (Solea aegyptiaca) juveniles. Aquaculture, 261: 580 - 586.

Bonaldo, A., Roem, A.J., Fagioli, P., Pecchini, A., Cipollini, I, Gatta, P.P. (2008) Influence o dietary levels of soybean meal on the performance and gut histology of gilthead sea bream (Sparus aurata L.) and European sea bass (Dicentrarchus labrax L.). Aquaculture Research, 39: 970 - 978.

Bruslé, J., Gonzales i Anadon, G. (1996) The structure and function of fish liver. In Fish Morphology: Horizon of New Research. Datta Munshi, Dutta H.M. (Eds) Balkema Publishers. Brokfied - USA, $434 \mathrm{pp}$.

Bureau, D.P. (2007) Rendered products in fish aquaculture feeds. Fish Nutritional Research Laboratory. Department of Animal and Poultry Science. University of Guelph, 179 - 194 pp.

Caballero, M.J., López-Calero, G., Socorro, J., Roo, F.J., Izquierdo, M.S., Fernandez, A.J. (1999) Combined effect of lipid level and fish meal quality on liver histology of gilthead seabream (Sparus aurata). Aquaculture, 179: 277 - 290.

Caballero, M.J., Obach, A., Rosenlund, G., Montero, D., Gisvold, M., Izquierdo, M.S. (2002) Impact of different dietary lipid sources on growth, lipid digestibility, tissue fatty acid composition and histology of rainbow trout, Oncorhynchus mykiss. Aquaculture, 214: 253 - 271. 
Caballero, M.J., Izquierdo, M.S., Kjørsvik, E., Montero, D., Socorro, J., Fernández, A.J., Rosenlund, G. (2003) Morphological aspects of intestinal cells from gilthead seabream (Sparus aurata) fed diets containing different lipid sources. Aquaculture, 225: 325 - 340.

Caballero, M.J., Izquierdo, M.S., Kjorsvik,E., Fernández, A.J., Rosenlund, G. (2004) Histological alterations in the liver of sea bream, Sparus aurata L., caused by short- or long-term feeding with vegetable oils. Recovery of normal morphology after feeding fish oil as the sole lipid source. Journal of Fish diseases, 27: 531 - 541 .

Chatzifotis, S., Esteban, A.G., Divanach, P. (2006) Fishmeal replacement by alfalfa protein concentrate in sharpsnout sea bream Diplodus puntazzo. Fisheries Science, 72: 1313 - 1315.

Craig, S.R., Gatlin, D.M. (1995) Coconut oil and beef tallow, but not tricaprylin, Can replace menhaden oil in the diet of red drum (Sciaenops ocellatus) without adversely affecting growth of fatty acid composition. Nutrient Metabolism, 002-3166/95

Díaz-López M., Pérez, M.J., Acosta, N.G., Tocher, D.R., Jerez, S., Lorenzo, A., Rodríguez, C. (2009) Effect of dietary substitution of fish oil by Echium oil on growth, plasma parameters and body lipid composition in gilthead seabream (Sparus aurata L.). Aquaculture Nutrition, 15: 500 - 512.

Dubnov-Raz G., Berry, E.M. (2008) High $\omega 6: \omega 3$ Fatty Acid Ratio. The Israeli Experience. In: Wild-Type Food in Health Promotion and Disease Prevention. F. De Meester \& R.R. Watson (Eds). Humana Press Inc. Totowa - New Jork - USA. 574 pp.

Escaffre, A-M., Kaushik, S., Mambrini, M. (2007) Morphometric evaluation of changes in the disgestive tract of rainbow trout (Oncorhynchus mykiss). Aquaculture, 273: 127 - 138.

Fehily, A.M., Pickering, J.E., Yarnell, J.W.G., Elwood, P.C. (1994) Dietary indices of atherogenicity and thrombogenicity and ischaemic heart disease risk: the Caerphilly Prospective Study. British Journal of Nutrition, 71: $249-257$.

Figueiredo-Silva, A., Rocha, E., Dias, J., Silva, P., Rema, P., Gomes, E., Valente, L.M.P. (2005) Partial replacement of fish oil by soybean oil on lipid distribution and liver histology in European sea bass (Dicentrarchus labrax) and rainbow trout (Oncorhynchus mykiss) juveniles. Aquaculture Nutrition, 11: 147 - 155.

Fountoulaki, E., Vasilaki, A., Hurtado, R., Grigorakis, K., Karacostas, I., Negas, I., Rigos, G., Kotzamanis, Y., Venou, B., Alexis, M.N. (2009) Fish oil substitution by vegetable oils in commercial diets for gilthead sea bream (Sparus aurata L.); effects on growth performance, flesh quality and fillet fatty acid profile. Recovery of fatty acid profiles by a fish oil finishing diet under fluctuating water temperatures. Aquaculture, 289: 317 - 326.

Francis, G., Harinder, P.S., Makkar, Becker, K. (2001) Antinutritional factors present in plant-derived alternate fish feed ingredients and their effect in fish. Aquaculture, 199: 197 - 227.

Francis, D.S., Turchini, G.M, Jones, P.L., De Silva, S.S. (2007) Growth performance, feed efficiency and fatty acid composition of juvenile Murray cod, Maccullochella peelii peelii, fed graded levels of canola and linseed oil. Aquaculture Nutrition, 13: 335 - 350.

Gandhi, A.P., Jha, K., Gupta, V. (2008) Technical Paper. Studies on the Production of Defatted Sunflower Meal with Low Polyphenol and Phytate Contents and its Nutritional Profile. ASEAN Food Journal, 15: $97-100$. 
Gatlin, DM. (2002) Nutrition and Fish Health. In Fish Nutrition (3er edition) J.E. Halver \& R.W. Hardy (Eds). $3^{\circ}$ Ed. Elsevier Science (USA), 824 pp.

Gatlin, D.M., Barrows, F.T., Brown, P., Dabrowski, K., Gibson Gaylord, T., Hardy, R.W., Herman, E., Hu, G., Krogdahl, A., Nelson, R., Overturf, K., Rust, M., Sealey, W., Skonberg, D., Souza, E.J., Stone, D., Wilson, R., Wurtele, E. (2007) Expanding the utilization of sustainable plant products in aquafeeds: a review. Aquaculture Research, 38: 551 - 579.

Gill, N., Higgs, D.A., Skura, B.J., Rowshandeli, M., Dosanjh, B.S., Mann, J., Gannam, A.I. (2006) Nutritive value of partially dehulled and extruded sunflower meal for post-smolt Atlantic salmon (Salmo salar L.) in sea water. Aquaculture Research, 37: 1348 - 1359.

Glencross, B., Hawkins, W., Curnow, J. (2003) Evaluation of canola oils as alternative lipid resources in diets for juvenile red seabream, Pagrus auratus. Aquaculture Nutrition, 9: 305 - 315.

Glencross, B.D. (2009) Exploring the nutritional demand for essential fatty acids by aquaculture species. Reviews in Aquaculture, 1: 71 - 124.

Grigorakis, K. (2007) Compositional and organoleptic quality of farmed and wild gilthead sea bream (Sparus aurata) and sea bass (Dicentrarchus labrax) and factors affecting it: A review. Aquaculture, 272: $55-75$.

Grisdale-Helland, B., Helland, S.J., Baeverfjord, G., Berge, G.M. (2002) Full-fat soybean meal in diets for Atlantic halibut: growth, metabolism and intestinal histology. Aquaculture Nutrition, 8: 265 270 .

Guillaume, J., Kaushik, S., Bergot, P., Métailler, R. (2004) Nutrición y alimentación de peces y crustáceos. INRA y Ed. Mundi - Prensa. Madrid - Barcelona - México. 471 pp.

Hernández, M.D., Martínez, F.J., Jover, M., García García, B. (2007) Effects of partial replacement of fish meal by soybean meal in sharpsnout seabream (Diplodus puntazzo) diet. Aquaculture, 263: 159 - 167.

Izquierdo, M.S., Obach, A., Arantzamendi, L., Montero, D., Robaina, L., Rosenlund, G. (2003) Dietary lipid sources for seabream and seabass: growth performance, tissue composition and flesh quality. Aquaculture Nutrition, 9: 397 - 407.

Kamaci, H.O., Coban, D., Suzer, C., Saka, S., Firat, K. (2009) Development of the Gastrointestinal Tract in Sharpsnout Sea Bream (Diplodus puntazzo) Larvae: Histological and Enzymatic Ontogeny. Journal of Animal and Veterinary Advances, 8: 2571 - 2579.

Krongdahl, A., Bakke-Mckellep, A.M., Baeverfjord, G. (2003) Effects of graded levels of standard soybean meal on intestinal structure, mucosal enzyme activities, and pancreatic response in Atlantic salmon (Salmo salar L.). Aquaculture Nutrition, 9: 361 - 371.

Krogdahl, A., Penn, M., Thorsen, J., Refstie, S., Bakke, A.M. (2010) Important antinutrients in plant feedstuffs for aquaculture: an update on recent findings regarding responses in salmonids. Aquaculture Research, 41: 333 - 344.

Laudadio, V., Tufarelli, V. (2010) Growth performance and carcass and meat quality of broiler chickens fed diets containing micronized - dehulled peas (Pisum sativum cv. Spirale) as a substitute of soybean meal. Poultry Science, 89: 1537 - 1543.

Li, P., Yin, Y-L., Li, D., Kim, S.W., Wu, G. (2007) Amino acids and immune function. Rewiew Article. British Journal of Nutrition, 98: $237-252$. 
Lie, Ø. (2001) Flesh quality - the role of nutrition. Aquaculture Research, 32: 341 - 348.

Liu, L.L.M., Barrows, F.T., Hardy, R.W., Dong, F.M. (2004) Body composition, growth performance, and product quality of rainbow trout (Oncorhynchus mykiss) fed diets containing poultry fat, soybean/corn lecithin, or menhaden oil. Aquaculture, 238: 309 - 328.

Martínez-Llorens, S., Tomás-Vidal, A., Moñino, V.A., Pla Torres, M., Jover Cerdá, M. (2007) Effects of dietary soybean oil concentration on growth, nutrient utilization and muscle fatty acid composition of gilthead sea bream (Sparus aurata L.). Aquaculture Research, 38: 76 - 81.

Marcouli, P.A., Alexis, M.N., Andriopoulou, A., Iliopoulou-Georgudaki, J. (2004) Development of a reference diet for use in indispensable amino acid requirement studies of gilthead seabream Sparus aurata L. Aquaculture Nutrition, 10: 335 - 343.

Mele, M., Morbidini, L., Cozza, F., Pauselli, M., Pollicardo, A. (2008) Organic beff production by Maremmana breed: aualitative meat characteristics. IFOAM Organic World Congress. Modena, Italy. June $16-20$.

Micale, V., Perdichizzi, F., Basciana, G. (1996) Aspects of the reproductive biology of the sharpsnout seabream Diplodus puntazzo (Cetti, 1777). Gametogenesis and gonadal cycle in captivity during the third year of life. Aquaculture, 140: 281 - 291.

Mourente, G., Good, J.E., Bell, J.G. (2005) Partial substitution of fish oil with rapeseed, linseed and olive oils in diets for European sea bass (Dicentrarchus labrax L.): effects on flesh fatty acid composition, plasma prostaglandins $\mathrm{E}_{2}$ and $\mathrm{f}_{2 \alpha}$ immune function and effectiveness of a fish oil finishing diet. Aquaculture Nutrition, 11: $25-40$.

Olsen, R.E., Dragnes, B.T., Myklebust, R., Ringø, E. (2003) Effect of soybean oil and soybean lecithin on intestinal lipid composition and lipid droplet accumulation of rainbow trout, Oncorhynchus mykiss Walbaum. Fish Physiology and Biochemistry, 29: 181 - 192.

Olsen, R.E., Hanse, A-C., Rjosenlund, G., Hemre, G-I., Mayhew, T.M., Knudsen, D.L., Eroldogan, O.T., Myklebust, R., Karlsen, Ø. (2007) Total replacement of fish meal with plant proteins in diets for Atlantic cod (Gadus morhua L.) - Health aspects. Aquaculture, 272: 612 - 624.

Øverland, M., Sørensen, M., Storebakken, T., Penn, M., Krogdahl, Å., Skrede, A. (2009) Pea protein concentrate substituting fish meal or soybean meal in diets for Atlantic salmon (Salmo salar) Effect on growth performance, nutrient digestibility, carcass composition, gut health, and physical feed quality. Aquaculutre, 288: $305-311$.

Papadaki, M., Papadopoulou, M., Siggelaki, I., Mylonas, C.C. (2008) Egg and sperm production and quality of sharpsnout sea bream (Diplodus puntazzo) in captivity. Aquaculture, 276: 187 - 197.

Penn, M.H., Bendiksen, E.A., Campbell, P., Krogdahl, A. (2011) Pea protein concentrate induces enteropaty in Atlantic salmon (Salmo salar L.). Aquaculture, 310: 267 - 273.

Peres, H., Oliva-Teles, A. (2005) The effect of dietary protein replacement by crystalline amino acid on growth and nitrogen utilization of turbot Scophthalmus maximus juveniles. Aquaculture, 250: 755 764.

Piedecausa, M.A., Mazón, M.J., García García, B., Hernández, M.D. (2007) Effects of total replacement of fish oil by vegetable oils in the diets of sharpsnout sea bream (Diplodus puntazzo). Aquaculture, 263: $211-219$ 
Razmaité, V., Svirmickas, G.J., Siukscius, A., Sveistiené, R. (2011) Comparative characterization of fatty acid profiles in intramuscular lipids from different domestic and wild mongastric animal species. Veterinarija ir Zootechnika (Vet. Med Zoot), 53: 45 - 50.

Rueda, F.M., Hernández, M.D., Egea, M.A., Aguado, F., García, B., Martínez, F.J. (2001) Differences in tissue fatty acid composition between reared and wild sharpsnout sea bream, Diplodus puntazzo (Cetti, 1777). British Journal of Nutrition, 86: 617 - 622.

Ruxton, C.H.S., Reed, S.C., Simpson, M.J.A., Millington, K.J. (2004) The health benefits of omega-3 polyunsaturated fatty acids: a review of the evidence. Journal of Human Nutrition Dietetic, 17: $449-459$

Sánchez-Lozano, N.B., Tomás-Vidal, A., Martínez-Llorens, S., Nogales-Mérida, S., Espert-Blanco, J., Moñino López, A., Pla Torres, M., Jover-Cerdá, M. (2007) Growth and economic profit of gilthead sea bream (Sparus aurata, L.) fed sunflower meal. Aquaculture, 272: 578 - 534.

Sánchez-Lozano, N.B., Martínez-Llorens, S., Tomás-Vidal, A., Jover Cerdá, M. (2011) Amino acid retention of gilthead sea bream (Sparus aurata, L.) fed with pea protein concentrate. Aquaculture Nutrition, 17: $604-614$.

Sargent, J.R., Tocher D.R., Bell, J.G. (2002) The Lipids. In: Fish Nutrition. J.E. Halver \& R.W. Hardy (Eds). $3^{\circ}$ Ed. Elsevier Science (USA), 824 pp.

Savona, B., Tramati, C., Mazzola, A. (2011) Digestive Enzimes in Larvae and Juveniles of Farmed Sharpsnout Seabream (Diplodus puntazzo) Cetti, 1777). The Open Marine Biology Journal, 5: 47 - 57.

Spisni, E., Tugnoli, M., Ponticelli, A., Mordenti, T., Tomasi, V. (1998) Hepatic steatosis in artificially fed marine teleosts. Journal of Fish Diseases, 21: 177 - 184.

Tocher, D.R., Bell, J.G., McGhee, F., Dick, J.R., Fonseca-Madrigal, J. (2003) Effects of dietary lipid level and vegetable oil on fatty acid metabolism in Atlantic salmon (Salmo salar L.) over the whole production cycle. Fish Physiology and Biochemistry, 29: 193 - 209.

Tocher, D.R. (2010) Review Article. Fatty acid requirement in ontogeny of marine and freshwater fish. Aquaculture Research, 41: $717-732$.

Tramati, C., Savona, B., Mazzola, A. (2005) A study of the pattern of digestive enzymes in Diplodus puntazzo (Cetti, 1777) (Osteichthyes, Sparidae) evidence for the definition of nutritional protocols. Aquaculture International, 13: 89 - 95.

Trushenski, J.T., Lochmann, R.T. (2009) Potential, implications and solutions regarding the use of rendered animal fats in aquafeeds. American Journal of Animal and Veterinary Sciences, 4: 108 128.

Turchini, G.M., Mentasti, T., Frøyland, L., Orban, E., Caprino, f., Moretti, V.M., Valfré, F. (2003) Effects of alternative dietary lipid sources on performance, tissue chemical composition, mitochondrial faty acid oxidation capabilities and sensory characteristics in brown trout (Salmo trutta L.). Aquaculture, 225: 251 - 267.

Turchini, G.M., Torstensen, B.E., Ng, W-K. (2009) Fish oil replacement in finfish nutrition. Reviews in Aquaculture, 1: $10-57$. 
Urán, P.A., Gonçalves, A.A. Taverne-Thiele, J.J., Schrama, J.W., Verreth, J.A.J., Rombout, J.H.W.M. (2008) Soybean meal induces intestinal inflammation in common carp (Cyprinus carpio L.) Fish \& Shellfish Immunology, 25: 751 - 760.

Vacca, G.M., Carcangiu, V., Dettori, M.L., Pazzola, M., Mura, M.C., Luridiana, S., Tilloca, G. (2008) Productive performance and meat quality of Mouflon x Sarda and Sarda x Sarda suckling lambs. Meat Science, 80: 326 - 334.

Valfré, F., Caprino, F., Turchini, G.M. (2003) The Health Benefit of Seafood. Veterinary Research Communications, 27: $507-521$.

Volek, Z., Marounek, M. (2011) Effect of Redding growing-fattening rabbits a diet supplemented with whole white lupin (Lupinus albus cv. Amiga) seeds on fatty acid composition an indexes related to human health in hind leg meat and perirenal fat. Meat Science, 87: 40 - 45.

Wang, X-X., Li, Y-J., Hou, C-L., Gao, Y., Wang, Y-Z. (2011) Influence of different dietary lipid sources on the growth, tissue fatty acid composition, histological changes and peroxisome proliferatoractivated receptor $\gamma$ gene expression in large yellow croaker (Pseudosciaena crocea R.). Aquaculture Research, 1 - 11 .

Wilson, R.P. (2002) Amino Acids and Proteins. In: Fish Nutrition. J.E. Halver \& R.W. Hardy (Eds). 3o Ed. Elsevier Science (USA), 824 pp.

Xue, M., Luo, L., Wu, X., Ren, Z., Gao, P., Yu, Y., Pearl, G. (2006) Effect of six alternative lipid sources on growth and tissue fatty acids composition in Japanese sea bass (Lateolabrax japonicus). Aquaculture, 260: 206 - 214.

Zhou, Q-B., Wu, H-D., Zhu, C-S., Yan, X-H. (2010) Effects of dietary lipids on tissue fatty acids profile, growth and reproductive performance of female rice field eel (Monopterus albus). Fish Physiology and Biochemistry. DOI 10.1007/s10695-010-9444-1. 

CAPÍTULO 11

\section{CONCLUSIONES}





\section{CAPITULO 11. CONCLUSIONES}

La inclusión parcial del TG hasta un 35\% no afecta ni el crecimiento ni la eficiencia nutritiva inclusive a nivel aminoacídico, aunque si se observa que estos piensos tienen que ser suplementados con metionina en la fase de pre-engorde y lisina para la fase de engorde, para evitar posibles alteraciones a largo plazo, puesto que los experimentos tuvieron una duración máxima de 6 meses. De igual forma, se ha visto en los peces en fase de pre-engorde este turtó no afecta la anatomía histológica del intestino como del hígado.

La inclusión del CPG influye en el crecimiento del sargo, probablemente causado por la presencia de compuestos anti-nutricionales termorresistentes que influyeron a nivel histológico observado en el intestino y también se pueda deber a la deficiente suplementación de la metionina en los piensos ensayados, lo que se evidencia a través de los índices empleados.

La sustitución parcial del AP por AS y MC no afecta al crecimiento de los sargos en fase de pre-engorde y engorde en breves periodos de tiempo (máximo seis meses). A pesar de que el perfil lipídico refleja el perfil de los piensos empleados, no se observa una reducción marcada en los HUFAS como es muy frecuente en las especies marinas, lo que permite platearse la posibilidad de que esta especie tenga cierta capacidad de bio-conversión del LNA en EPA y DHA y del LA en ARA.

A nivel histológico se observa que sólo los sargos en la fase de engorde alimentados con AP y MC presentan alteraciones hepáticas posiblemente a consecuencia de que los animales se encontrasen en la fase reproductiva, puesto que esta etapa suele ocasionar alteraciones en el hígado de los peces, como se constató a través de la histología de las gónadas.

La calidad organoléptica de los filetes del sargo picudo no se ha alterado por el empleo de AS y MC, asimismo, éstos presentan buenos índices (IA, IT y relación n6/n3) que indican que son beneficiosos para la salud humana. 
